\title{
INTERACTIONS BETWEEN THE PROGRADING GIANT FORESETS FORMATION AND A SUBSIDING DEPOCENTRE: INSIGHTS FROM THE PARIHAKA 3D \& ES89 2D SEISMIC SURVEYS
}

\author{
By \\ Aaron Graeme Johnston
}

\begin{abstract}
A thesis
submitted to the Victoria University of Wellington in fulfilment of the requirements for the degree of Master of Science in Petroleum Geoscience
\end{abstract}

Victoria University of Wellington

2014 


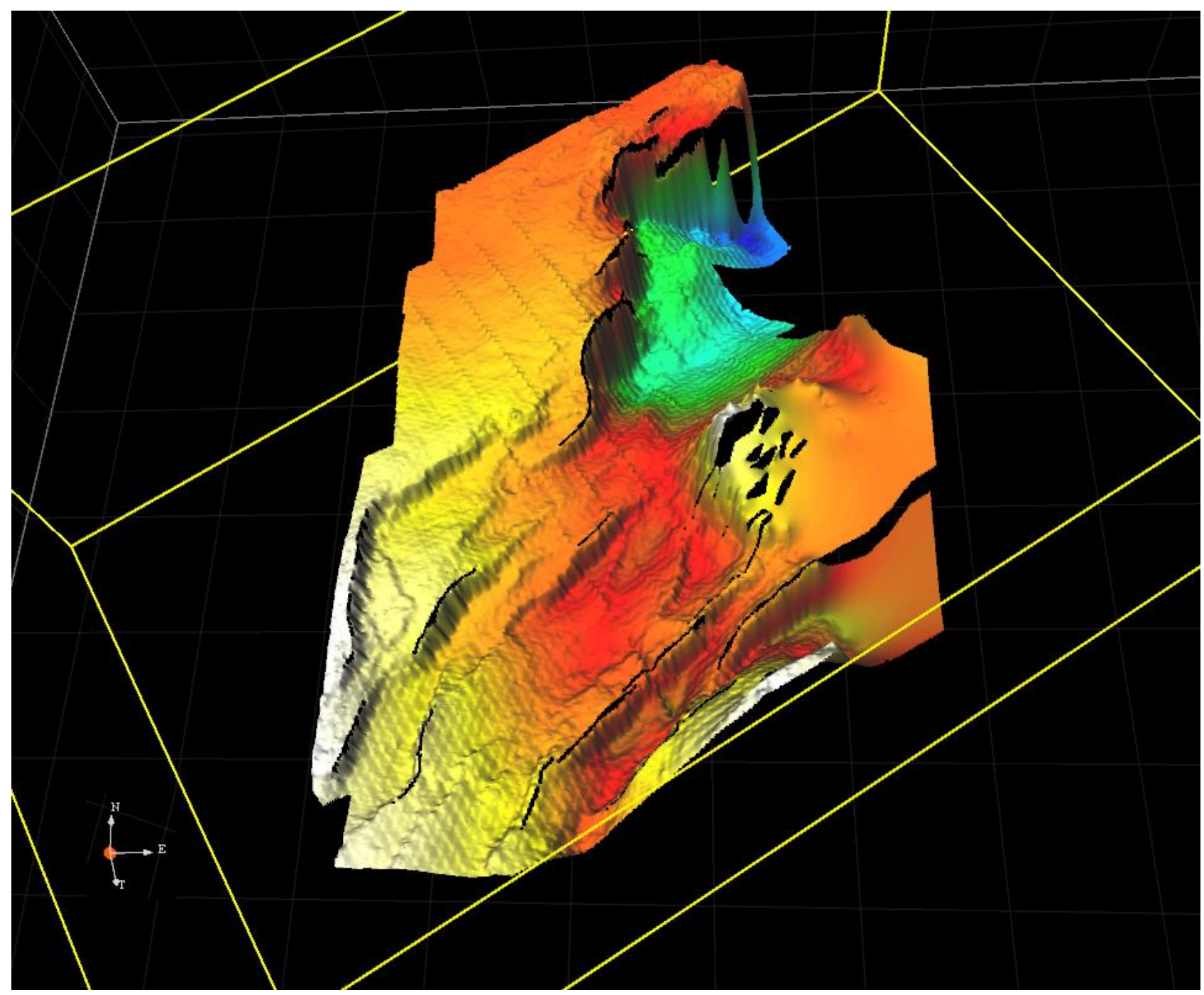

Frontispiece: Three-dimensional grid map of the base of the foresetting sequence of the Giant Foresets Sequence, Parihaka 3D seismic survey, Taranaki Basin, New Zealand. 


\begin{abstract}
This seismic interpretation project provides new insights into the interaction between the Pliocene-aged Giant Foresets Formation and the faults bounding the Northern Graben. A newly named fault-bounded depocentre within the North Taranaki Graben, the Arawa SubBasin, has subsided during the Pliocene, attracting volumes of sediment across the Parihaka Fault within large-scale channels. The study images kilometer-scale channels and explores the interplay between the progradation of the Giant Foresets Formation and normal faulting along the Cape Egmont Fault Zone. A focus is placed on imaging the provenance and depositional facies of sedimentary packages throughout the foresetting sequence of the Giant Foresets Formation.
\end{abstract}

Mapping of the Waipipian-Nukumaruan-aged foresetting sequence within the offshore northern Taranaki Basin has previously shown the primary sediment transport direction is primarily NNW. This is contradicted by sediment-transport features mapped within the study area showing the sediment transport direction fluctuates between NE and SE. The primary mechanism of sediment redirection is faulting along the Cape Egmont Fault Zone and subsidence within the North Taranaki Graben, an elongate SW-NE graben within the northern Taranaki Basin. Smaller ( 10s m-scale) channels concentrate into much larger ( $\sim 100 \mathrm{~s} \mathrm{~m}$ - to km-scale) mega-channels that travel E/NE into the subsiding Arawa Sub-Basin. Volcanic intrusions of the Mohakatino Volcanic Formation have also influenced the evolution of the mega-channels in the study area, via uplift and doming of the seafloor which provided a barrier to the transport of sediment.

The Parihaka 3D and ES89 2D seismic surveys are interpreted using the IHS Kingdom software package to create a basic framework of horizons and faults over the PlioceneRecent interval. Depth grid maps are produced from the grid of horizon picks. Isochore maps are produced which span key intervals between depth grids. A coherency cube of the Parihaka 3D is generated from the 3D seismic volume using OpendTect. Using the framework of faults and horizons within the coherency cube, imaging sediment transport and deposition features in the vicinity of normal faulting is made possible by flattening on a 
top foresets horizon and horizontally slicing the data at regular intervals. This recreates past conditions by removing the effects of fault-slip and differential compaction. These "timeslices" contain clear images of channels, canyons and fan-deposits allowing sediment provenance and transport direction to be mapped and interpreted. Finally, seismic section images from the Parihaka 3D and ES89 2D seismic surveys are generated along paths intersecting key geological features within the study area. 


\section{Acknowledgments}

During the 6 years of on-again, off-again study I have been fortunate enough to receive support and guidance from a large number of people l'm grateful to call my friends, family, colleagues and mentors. I apologise to those I have missed.

First thanks must go to my two generous and patient supervisors who have expertly guided me through the past year. Glenn Thrasher, thank you for all of the productive discussion and knowledge imparted from master to eager pupil. You are a deep well of knowledge and a genuine inspiration to me as a newbie just starting out in this industry. Even before I began my thesis, while working in the offices of Todd Energy, you were never short of a minute to help put me on the right path or explain a concept. Tim Stern, thank you for your guidance when the direction of my thesis wandered aimlessly. You've always been a strong advocate for me and I'm extremely grateful. I have to also thank you for suggesting scholarships and opportunities to me, which have always proven to be very favourable! Special mention to Dave Bennett who also very kindly lent a hand in finally settling on a topic.

My colleagues at Todd Energy who have been there for a laugh, a chat and a few beers after a long week. Stephen Greaves, your help with the coherency cube volume formed the cornerstone of my thesis and I will always be in your debt for that. Not to mention all the productive discussion. Paul Viskovic for keeping me sane during the year-long battle against lethargy and indifference. Rick Henderson for imparting any and all manner of Kingdom wrangling I never knew was possible. Hugh Mingard for generously sharing some of your limited time in Wellington with me for productive geological discussion. Mark Blood for being so accommodating of my studies and "unique" schedule, and for being a great advocate when it came time to find full-time employment.

Thanks must also go to my friends and family: Mum, Dad, Elaine and Leona for keeping me solvent during the hard times and supplying a hot meal or two along the way. Baz, Dean and Dylan - three of the best mates a guy could ask for and a constant source of banter. Brothers for life. Rebecca, Renata and Gabriel. You guys are a constant source of inspiration! And Gabrielle for being my biggest advocate for so long. 
Finally, my most sincere thanks to the Westergaard family. As you are well aware, I am honoured and grateful to be the first recipient of a scholarship that represents so much more than just academic achievement.

"You were born a child of light's wonderful secretyou return to the beauty you have always been."

- Aberjhani, Visions of a Skylark Dressed in Black 


\section{Table of Contents}

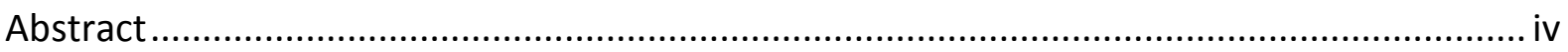

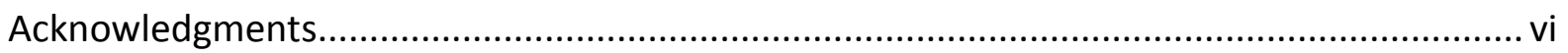

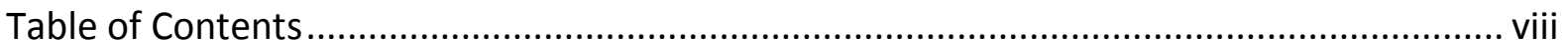

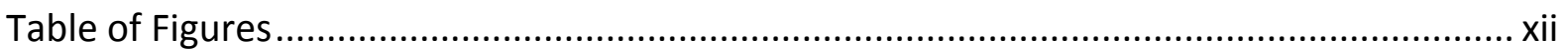

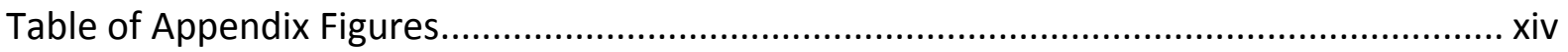

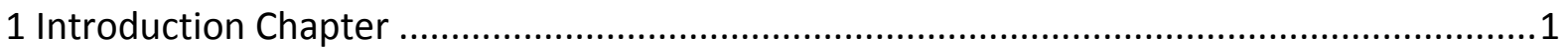

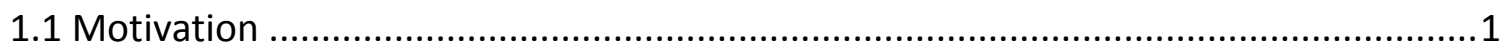

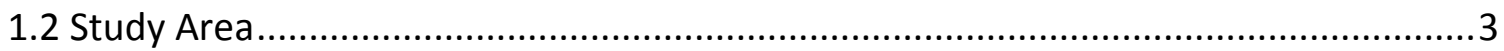

Former Petroleum Exploration Permits .................................................... 4

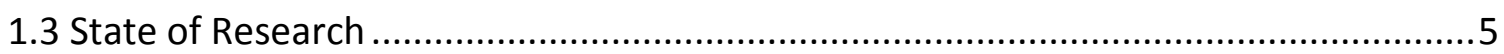

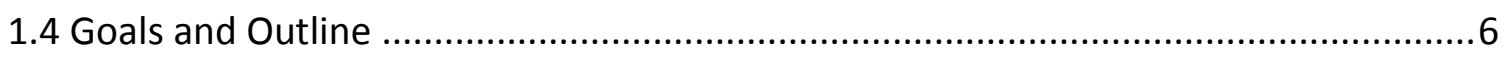

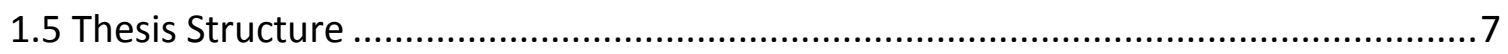

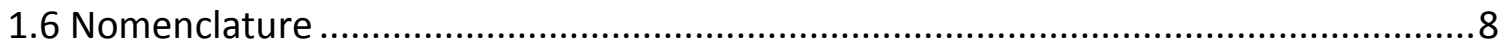

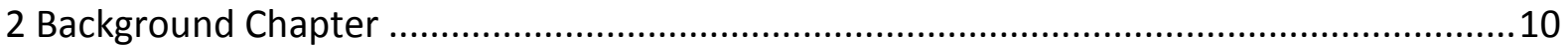

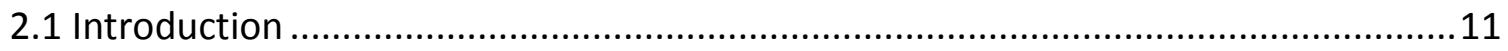

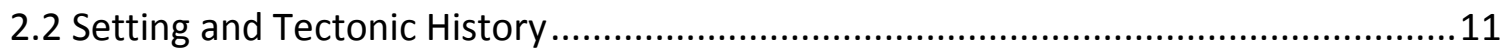

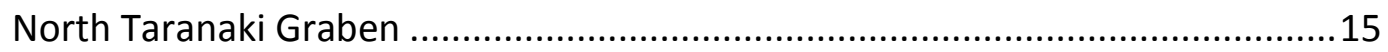

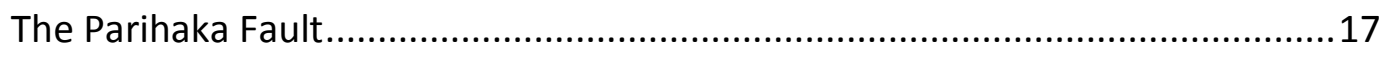

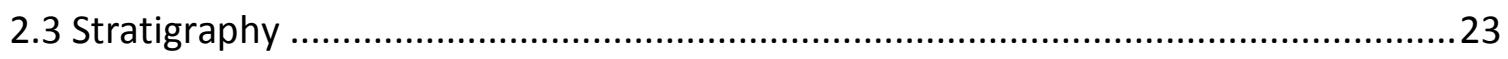

North Taranaki Graben ............................................................................2 26

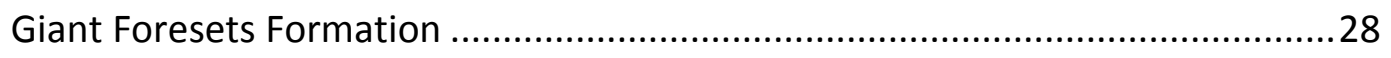

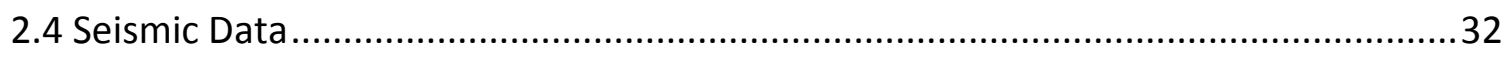

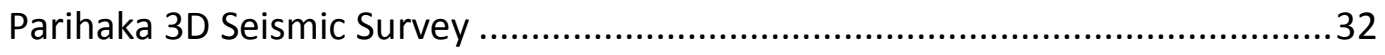

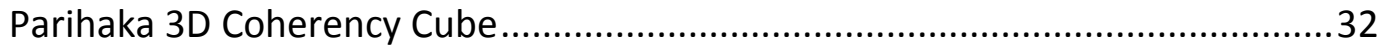

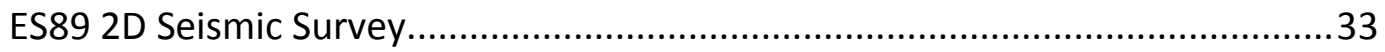




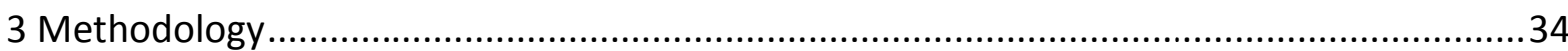

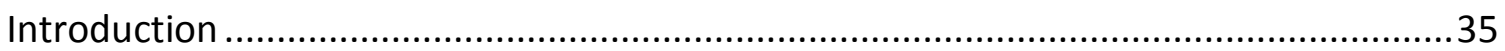

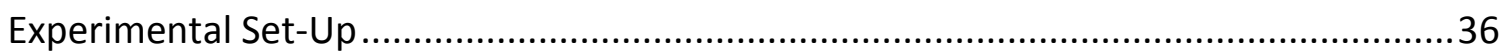

New Zealand Petroleum \& Minerals GOLD Database .......................................36

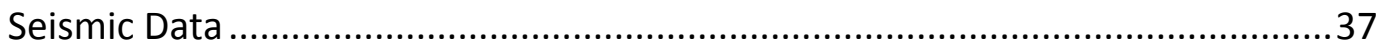

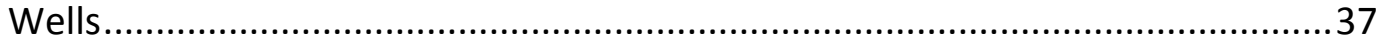

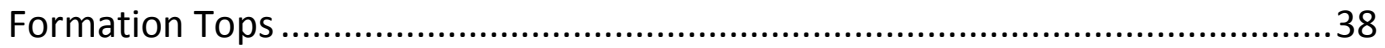

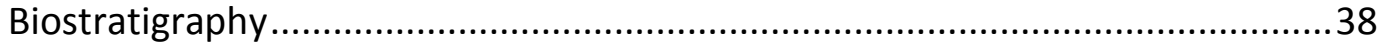

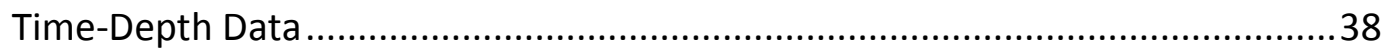

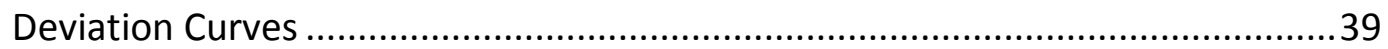

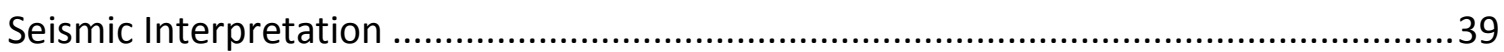

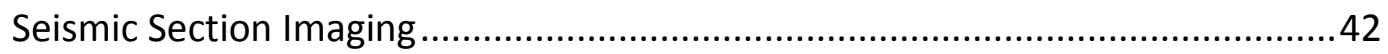

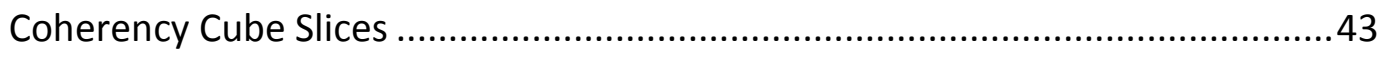

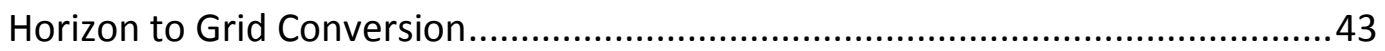

Time to Depth Grid Conversion ................................................................... 44

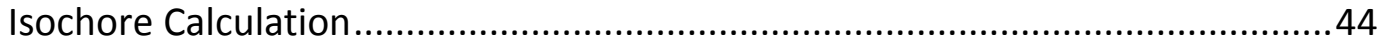

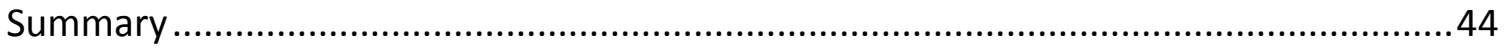

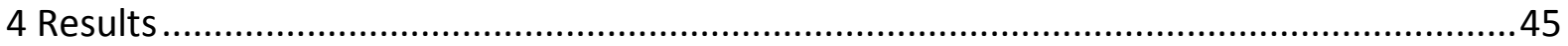

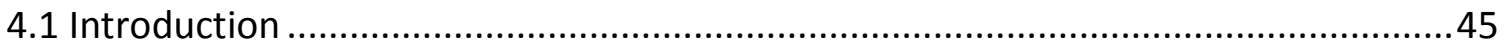

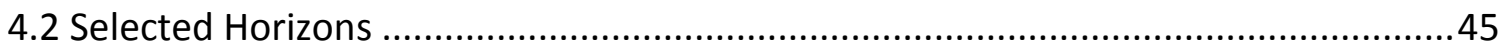

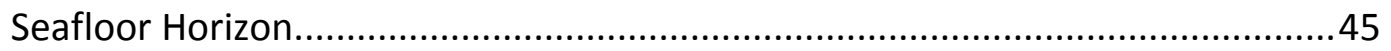

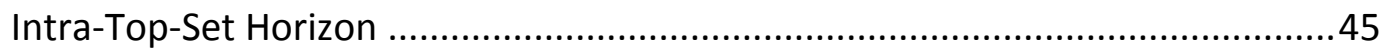

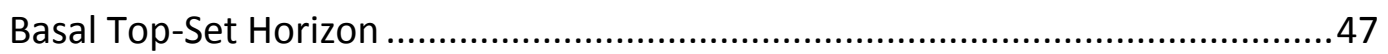

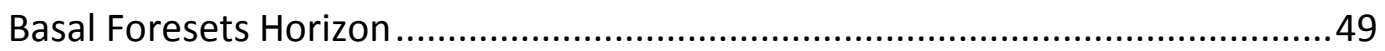

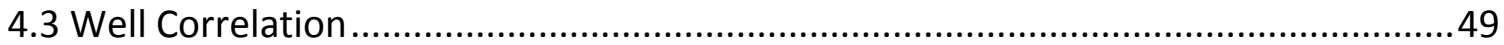




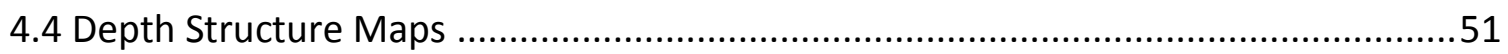

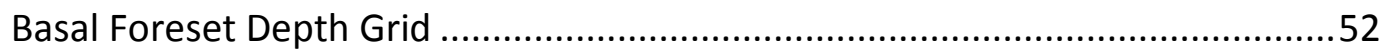

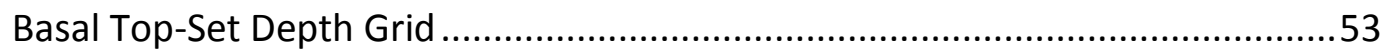

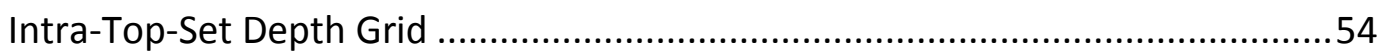

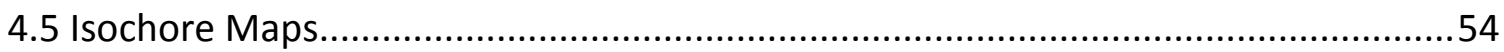

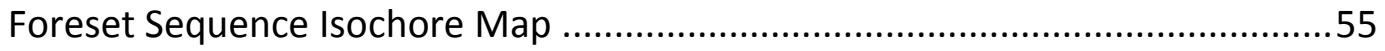

Lower Top-Set Sequence Isochore Map …......................................................57

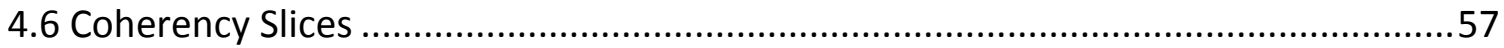

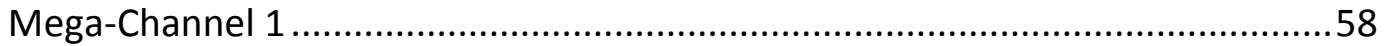

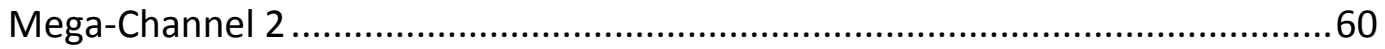

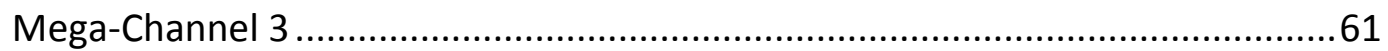

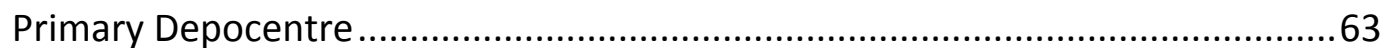

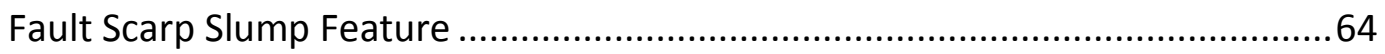

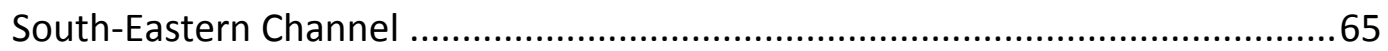

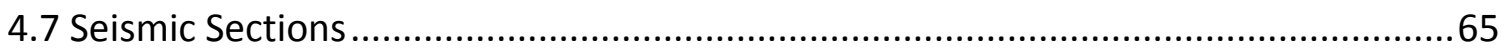

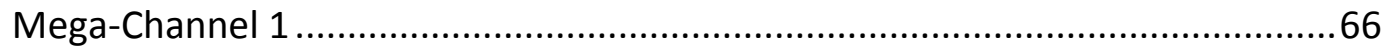

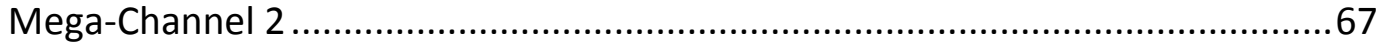

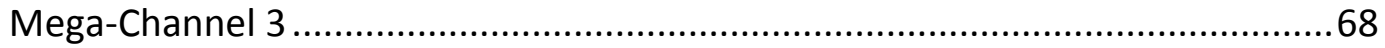

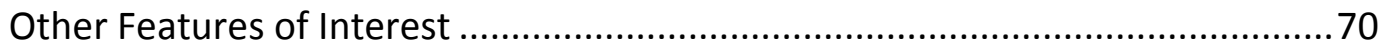

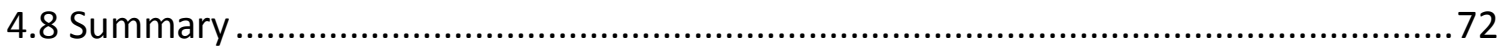

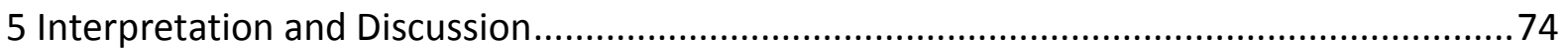

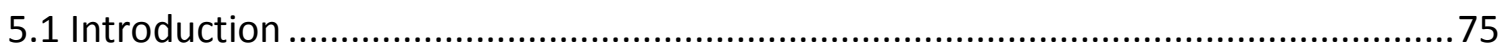

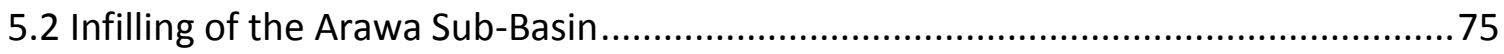

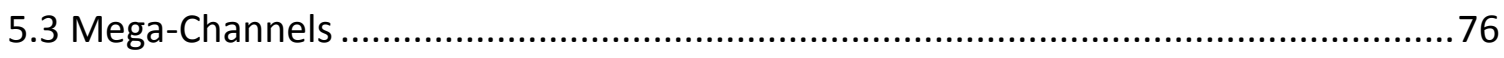

Formation of the Mega-Channels ................................................................... 77

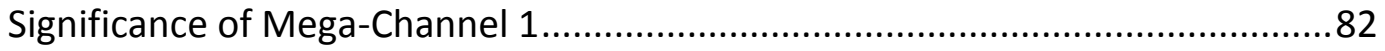




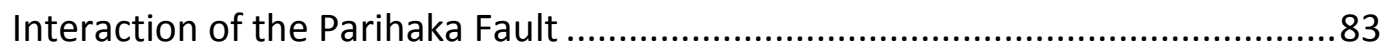

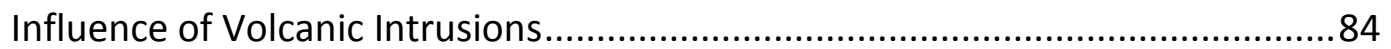

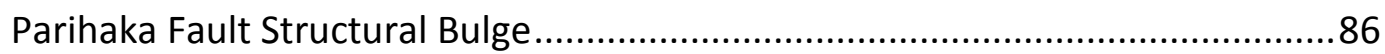

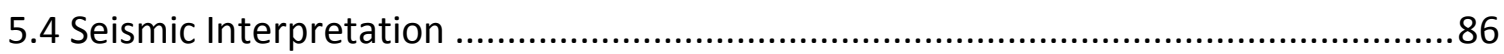

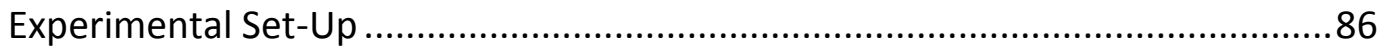

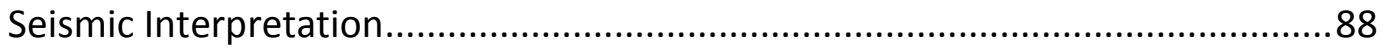

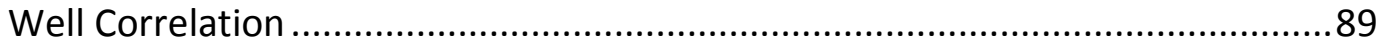

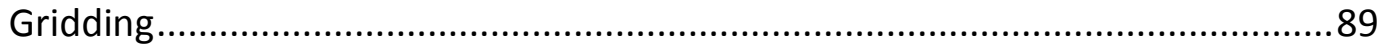

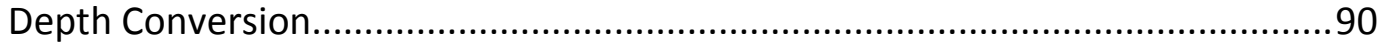

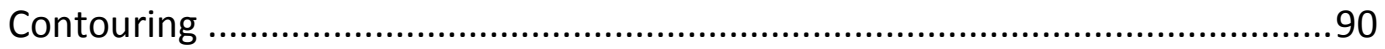

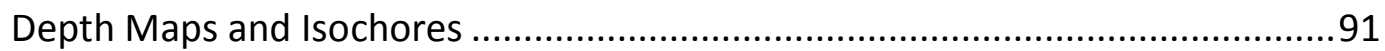

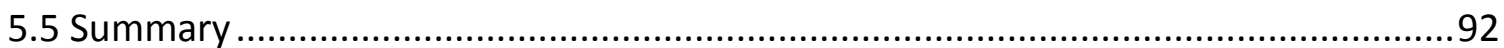

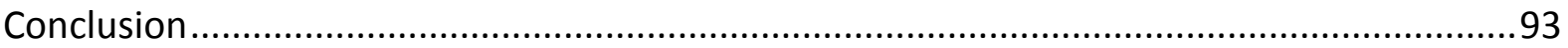

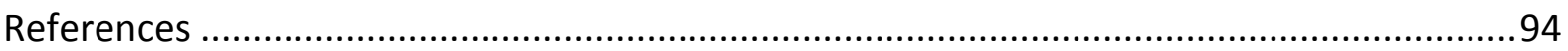

Appendix A: Coherency Cube Time-Slices ................................................................ 100

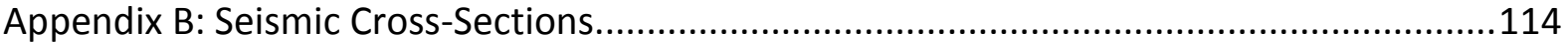

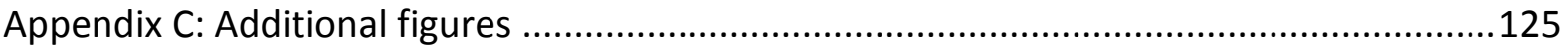

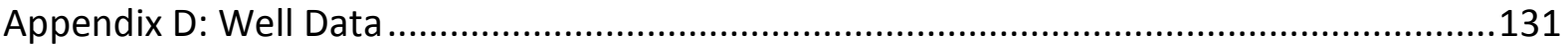

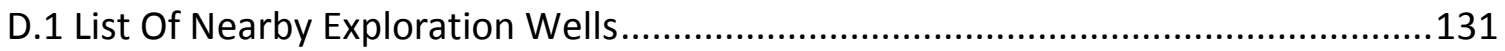

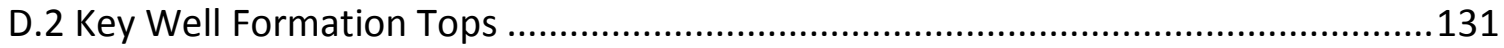

D.3 Key Well Biostratigraphy Interval Results .........................................................132

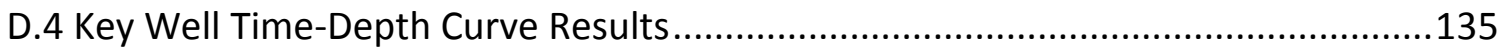

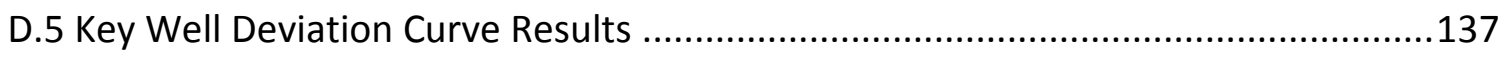




\section{Table of Figures}

Figure 1.1: Location map of the Taranaki Basin .........................................................

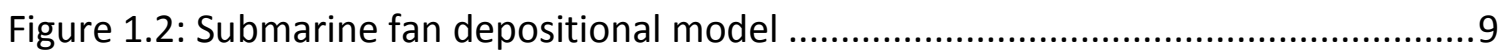

Figure 2.1: Structural elements map of the New Zealand Continent .............................12

Figure 2.2: Structural elements map of the Taranaki Basin. ......................................13

Figure 2.3: Generalised schematic of the North Taranaki Graben block rotation model 17

Figure 2.4: Parihaka Fault trace map at four stratigraphic levels................................. 18

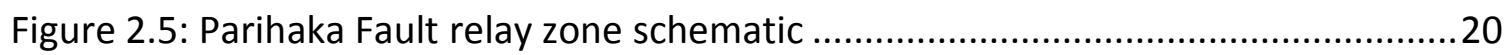

Figure 2.6: Fault offset on the Parihaka Fault from Cretaceous-Recent ........................21

Figure 2.7: Sigmoidal and straight fault shapes of segments within the Parihaka Fault .22

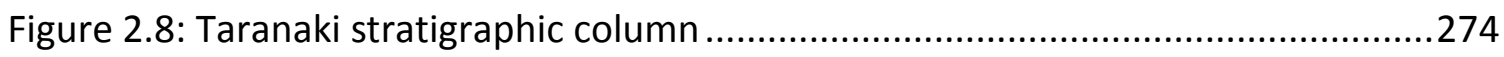

Figure 2.9: Pliocene-Recent North Island structural features map .............................297

Figure 2.10: Giant Foresets Formation isopach maps through Pliocene ......................249

Figure 2.11: Schematic illustration of the Giant Foresets Formation divisions ................31

Figure 4.1(a): Arbitrary seismic section between Taimana-1, Arawa-1 and Witiora-1....46

Figure 4.1(b): Arbitrary seismic section between Arawa-1 and Okoki-1......................48

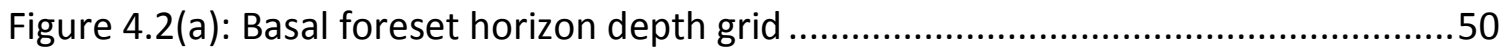

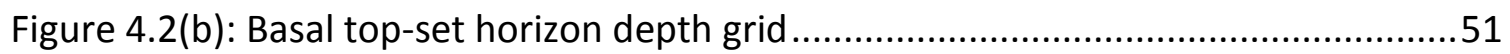

Figure 4.2(c): Intra-top-set horizon depth grid.....................................................52

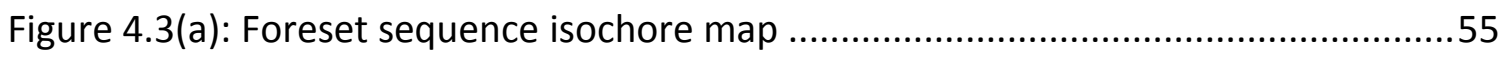

Figure 4.3(b): Lower top-set sequence isochore map ............................................56

Figure 4.4(a): Annotated coherency time-slice highlighting upper portion of mega-

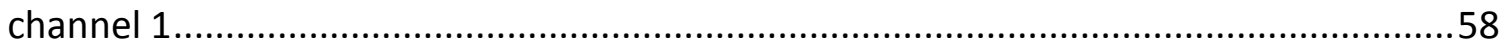

Figure 4.4(b): Annotated coherency time-slice highlighting lower portion of megachannel 1 ..... 
Figure 4.4(c): Annotated coherency time-slice highlighting upper portion of megachannel 2

Figure 4.4(d): Annotated coherency time-slice highlighting lower portion of megachannel 2 .

Figure 4.4(e): Annotated coherency time-slice highlighting upper portion of megachannel 3

Figure 4.4(f): Annotated coherency time-slice highlighting lower portion of mega-

channel 3.

Figure 4.4(g): Annotated coherency time-slice highlighting the SE channel complex.....64

Figure 4.5(a): Annotated seismic section of crossline 5000 of the Parihaka 3D

highlighting the main features of mega-channel 1.

Figure 4.5(b): Annotated seismic section of crossline 4500 of the Parihaka 3D

highlighting the main features of mega-channels 2 and 3

Figure 4.5(c): Annotated seismic section of crossline 5000 of the Parihaka 3D

highlighting the main features of mega-channels 2 and 3

Figure 4.6(a): Arbitrary seismic sections oriented along the length of mega-channel 1 within the Parihaka 3D seismic survey

Figure 4.6(b): Arbitrary seismic sections oriented along the length of mega-channel 2 within the Parihaka 3D seismic survey

Figure 4.6(c): Arbitrary seismic sections oriented along the length of mega-channel 3 within the Parihaka 3D seismic survey

Figure 5.1: Schematic diagram of submarine channel formation

Figure 5.2: Schematic illustration of the evolution of mega-channels in the study area 80 


\section{Table of Appendix Figures}

Appendix figure A.1(a): Parihaka 3D seismic survey coherency cube time-slice $50 \mathrm{~ms}$ above the basal top-set horizon

Appendix figure A.1(b): Parihaka 3D seismic survey coherency cube time-slice $25 \mathrm{~ms}$ above the basal top-set horizon

Appendix figure A.1(c): Parihaka 3D seismic survey coherency cube time-slice level with the basal top-set horizon

Appendix figure A.1(d): Parihaka 3D seismic survey coherency cube time-slice $25 \mathrm{~ms}$ below the basal top-set horizon

Appendix figure A.1(e): Parihaka 3D seismic survey coherency cube time-slice $50 \mathrm{~ms}$ below the basal top-set horizon

Appendix figure A.1(f): Parihaka 3D seismic survey coherency cube time-slice $75 \mathrm{~ms}$ below the basal top-set horizon

Appendix figure A.1(g): Parihaka 3D seismic survey coherency cube time-slice $100 \mathrm{~ms}$ below the basal top-set horizon

Appendix figure A.1(h): Parihaka 3D seismic survey coherency cube time-slice $125 \mathrm{~ms}$ below the basal top-set horizon

Appendix figure A.1(i): Parihaka 3D seismic survey coherency cube time-slice $150 \mathrm{~ms}$ below the basal top-set horizon

Appendix figure A.1(j): Parihaka 3D seismic survey coherency cube time-slice $175 \mathrm{~ms}$ below the basal top-set horizon

Appendix figure A.1(k): Parihaka 3D seismic survey coherency cube time-slice $200 \mathrm{~ms}$ below the basal top-set horizon

Appendix figure A.1(I): Parihaka 3D seismic survey coherency cube time-slice $225 \mathrm{~ms}$ below the basal top-set horizon

Appendix figure A.1(m): Parihaka 3D seismic survey coherency cube time-slice $250 \mathrm{~ms}$ below the basal top-set horizon 
Appendix figure B.1(a): Seismic cross-section of crossline 3500 of the Parihaka 3D seismic survey

Appendix figure B.1(b): Seismic cross-section of crossline 3750 of the Parihaka 3D

seismic survey

Appendix figure B.1(c): Seismic cross-section of crossline 4000 of the Parihaka 3D

seismic survey

Appendix figure B.1(d): Seismic cross-section of crossline 4250 of the Parihaka 3D

seismic survey

Appendix figure B.1(e): Seismic cross-section of crossline 4500 of the Parihaka 3D seismic survey

Appendix figure B.1(f): Seismic cross-section of crossline 4750 of the Parihaka 3D

seismic survey

Appendix figure B.1(g): Seismic cross-section of crossline 5000 of the Parihaka 3D

seismic survey

Appendix figure B.1(h): Seismic cross-section of crossline 5250 of the Parihaka 3D

seismic survey

Appendix figure B.1(i): Seismic cross-section of line ES89-118 of the ES89 2D seismic survey

Appendix figure B.1(j): Seismic cross-section of line ES89-116 of the ES89 2D seismic survey

Appendix figure B.1(k): Seismic cross-section of line ES89-114 of the ES89 2D seismic survey

Appendix figure C.1: Acquisition parameters for the Parihaka 3D seismic survey

Appendix figure C.2: OpendTect settings from the coherency cube conversion of the Parihaka 3D seismic survey

Appendix figure C.3: ES89 2D seismic survey acquisition parameters

Appendix figure C.4: Loading parameters for the 2011 PreSTM reprocessing version of the Parihaka 3D seismic survey 
Appendix figure C.5: Screenshot of the EBCDIC header from ES89-118 2D seismic line

Appendix figure C.6: Geological time scale of the International and New Zealand time series covering the Middle Miocene-Recent period 128

Appendix figure C.7: Graphed results of time-depth velocity surveys from wells proximal to and within the study area

Appendix figure C.8: Final gridding parameters employed in the horizon to grid conversion process .129

Appendix figure C.9: Geometric features of a meandering channel. 126 


\section{Introduction Chapter}

\subsection{Motivation}

Mapping of the Pliocene to Pleistocene-aged Giant Foresets Formation shows the sedimenttransport direction oriented dominantly to the N/NW (Pilar \& Wakefield, 1978; Hansen \& Kamp, 2002). These conclusions are based on lower resolution 2D seismic data which show general trends but are unable to delineate fine-scale sediment flow characteristics out of plane of section. Although moderately dense ( $\sim 5 \mathrm{~km}$ line spacing) 2D grids have been utilised in the past, interpretations have been limited to medium- to large-scale features of the formation. The current paradigm of a largely linear shelf/slope prograding to the N/NW is contradicted by the results of this study that illustrate both small (order of $50 \mathrm{~m}$ scale) and large (order of one kilometer width scale) channels indicating sediment transport eastward proximal to, and crossing, the Cape Egmont Fault Zone in the area of the Parihaka 3D seismic survey.

This study aims to documented the fine-scale detail of the Giant Foreset Formation that may impact our greater understanding of the evolution of the Pliocene section within the North Taranaki Graben as well as the mechanisms by which the Giant Foreset Formation prograded. Interpretation of the $1520 \mathrm{~km}^{2}$ Parihaka 3D seismic dataset in conjunction with a post-processing coherency volume of the seismic data provides a high level of detail $(<0.1$ $\mathrm{km}$ lateral) in order to interpret the depositional characteristics of the Giant Foreset Formation. These characteristics are further explored using 2D lines from the ES89 survey, which expand the study area beyond the extent of the 3D survey to track the locus of deposition.

The Giant Foreset Formation has influenced the late-early Pliocene to Recent sedimentary and geomorphological history of the Taranaki Basin (Pilar \& Wakefield, 1978). The large thickness of the formation, reaching $2200 \mathrm{~m}$ in places, and high rate of deposition has affected burial, maturation, and heat-flow of source rock sediments, while also influencing reservoir quality (e.g. compaction, cementation and maximum burial depth) of the underlying sedimentary section (Hansen \& Kamp, 2002; Funnell et al., 1996). 


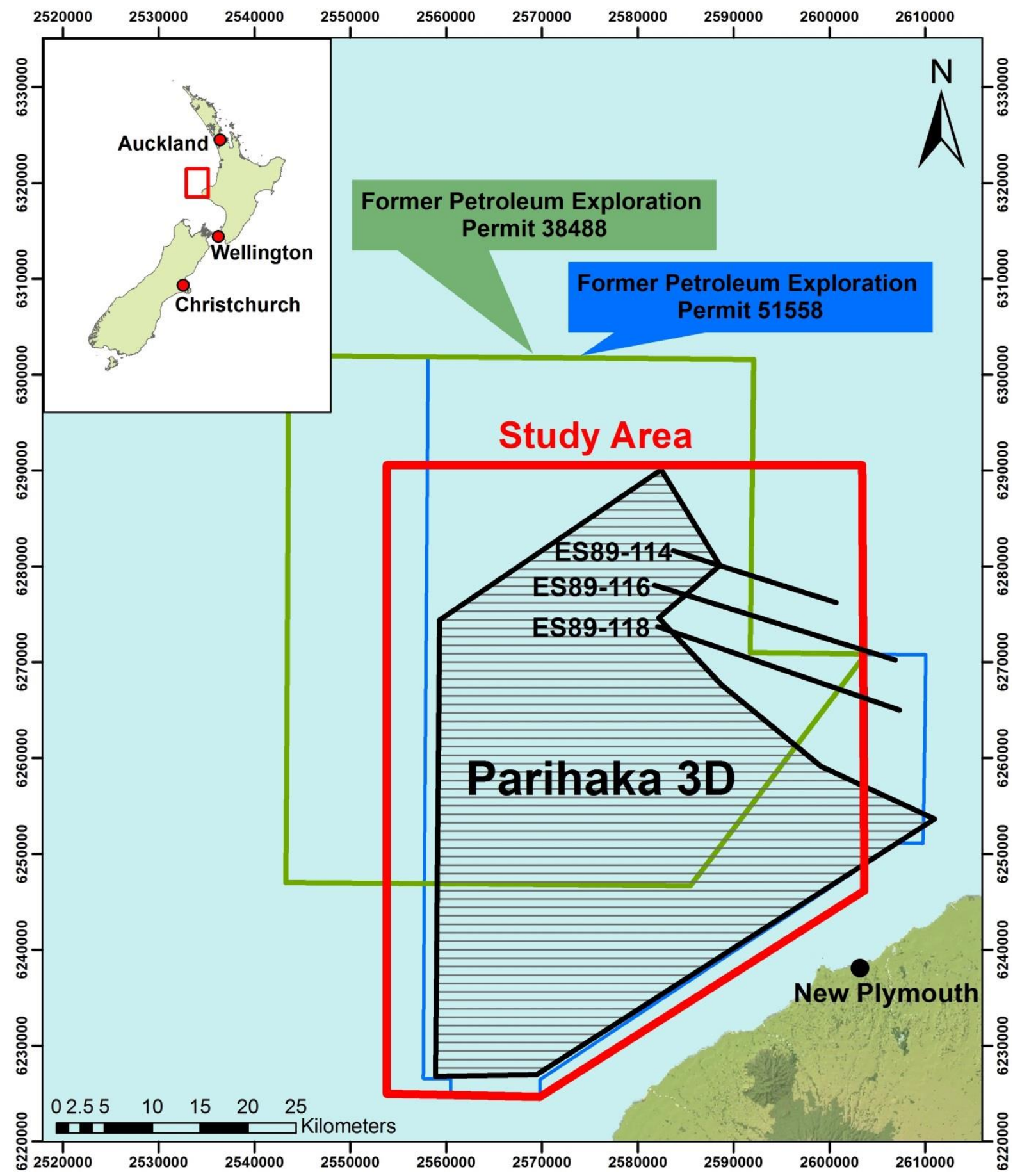

Figure 1.1: Location map of the Taranaki Basin showing the maximum extent of the study area (red polygon) Parihaka 3D seismic survey (black striped polygon), ES89 2D seismic survey lines (black lines) and former Petroleum Exploration Permits 38488 and 51558 (blue and green polygons). Main map extent is indicated by the red rectangle (inset map). Map coordinate system is New Zealand Map Grid.

A second objective that this study aims to address is the role syn-sedimentary volcanism has played in the distribution of sediment within the Northern Graben. Previous research has indicated that the Mohakatino Volcanic Complex was primarily intrusive, and doming of 
strata is evident in seismic cross-section (Luke, 2012; Giba et al., 2013). The role that this doming has played in redistributing and redirecting sediment flow is an important question that is yet to be addressed in the northern Taranaki Basin. The high quality seismic and coherency data utilised in this study provide an excellent opportunity to address this topic.

\subsection{Study Area}

This study is located in the Taranaki Basin, a broad sedimentary basin on the western side of the North Island, New Zealand (Figure 1.1). The Taranaki Basin covers $\sim 100,000 \mathrm{~km}^{2}$, with the majority of the basin lying offshore at water depths between 50-250 m. The Taranaki Basin is New Zealand's only hydrocarbon-producing region with a 150 year-long history of oil and gas exploration. The first exploration well, Alpha, was drilled in 1865. Subsequently, there has been continuous hydrocarbon production in the basin since approximately 1906 . Several globally significant discoveries have been made since the 1950s, including the Maui and Kapuni fields. There are currently 15 producing fields within the basin, and several more discoveries under development or considered sub-commercial at present. Although more than 400 wells have been drilled in the basin, it is considered relatively under-explored in terms of oil and gas exploration.

The immediate study area lies offshore to the NW of the Taranaki peninsula, within the former Petroleum Exploration Permit 51558 (Fig. 1.1). The study area covers the southeastern extent of the Northern Graben, a large faulted depression with up to $2 \mathrm{~km}$ of subsidence relative to the surrounding platforms. The Mohakatino Volcanic Complex runs along the axis of the graben. There are several intrusive edifices within the study area.

The $1520 \mathrm{~km}^{2}$ Parihaka 3D seismic survey is centred approximately $25 \mathrm{~km}$ to the NW of New Plymouth, on the north-western Taranaki Peninsula (Fig. 1.1) (Veritas, 2005). The ES89 seismic survey sits NE of the Parihaka 3D survey, covering a broad offshore area north of the Taranaki Peninsula within and to the NE of the study area (GECO NZ, 1989). There are 5 key wells within or closely offset from the study area. Water depths in the study area are between $50-150 \mathrm{~m}$

The study area covers the south-western termination of a geological feature known as the North Taranaki Graben. The graben is a down-faulted region of extension that has been 
active since the Late Miocene. New Zealand Petroleum and Minerals considers the North Taranaki Graben to be an under-explored but highly prospective area for oil and gas exploration (NZPAM, 2013). At least three significant discoveries have been made in the North Taranaki Graben at a similar stratigraphic level to the Giant Foreset Formation. To the north of the study area is the Miocene-aged Kora oil discovery which is currently considered sub-economic. North-east of the study area is the Pliocene Karewa biogenic gas discovery, also yet to be commercially developed. The 2010 exploration well, Awakino South-1 on the eastern margin of the North Taranaki Graben also discovered a hydrocarbon accumulation within the Eocene-aged Turi Formation however results of the discovery remain confidential.

\section{Former Petroleum Exploration Permits}

Former Petroleum Exploration Permit 38488 was granted February 2004 and operated by Pogo New Zealand with 50\% permit interest. Mighty River Power and Mitsui E\&P Australia each held $25 \%$ of the remaining permit equity. The joint venture participants were responsible for the acquisition and initial processing of the Parihaka 3D seismic survey in early 2005. Following the failure of the Kanuka-1 exploration well to discover a commercial hydrocarbon accumulation in late 2007, the joint venture participants made the decision to relinquish the permit in February 2009 (PR3843: Bates \& Heid, 2007).

The area formerly included as Petroleum Exploration Permit 38488 was subsequently granted to AWE New Zealand as Petroleum Exploration Permit 51558 as operator with a 33 1/3\% permit equity in September 2009. Mitsui E\&P Australia and Mighty River Power Gas Investments each held an even split of the remaining $662 / 3 \%$ permit equity. Todd Energy entered the permit in 2009 , taking up a $20 \%$ share of the permit as a minority equity holder. Following the exit of AWE New Zealand PTY Ltd and Mitsui E\&P Australia PTY in August 2011, Todd Energy took a 50\% stake, and operatorship of the permit, with NZOG acquiring the remaining $50 \%$ equity. The permit joint venture undertook a reprocessing (including post-stack depth migration) of the Parihaka 3D seismic survey in 2013 (WesternGeco, 2012). The permit was relinquished by the joint venture parties in February 2014. 


\subsection{State of Research}

The Taranaki Basin has been extensively studied in the search for oil and gas accumulations within the basin. The geology of Taranaki is the most completely understood of all the sedimentary basins in New Zealand. The 100+ year exploration history has generated large volumes of geological data points that have in turn allowed for the production of detailed geological reconstructions of the basin history (e.g. Pilar \& Wakefield, 1978; Holt \& Stern, 1991; Holt \& Stern, 1994; King \& Thrasher, 1996; King, 2000). Information acquired by national and international petroleum exploration companies during tenured permit periods are automatically made publically available after a 5 year confidentiality period, or upon permit relinquishment. Other studies and reports produced by Crown Research Institutes (e.g. GNS Science, National Institute of Water and Atmospheric Research) and universities (e.g. Victoria University of Wellington, Waikato University, and Auckland University) are often made publicly available during the publication process.

The Taranaki Basin is a foreland basin containing up to $10 \mathrm{~km}$ of sedimentary section (Holt \& Stern, 1994). Rifting during the Late Cretaceous and early Paleogene produced localised faulting and subsidence, followed by regional passive thermal subsidence during the Eocene. Compression in the Oligo-Miocene generated foreland thrust loading along the Taranaki Fault, causing a widespread downwarping of the continental crust with a wavelength of $\sim 150 \mathrm{~km}$. The accomodation space produced by the regional downwarping was subsequently infilled during Plio-Pleistocene by the Giant Foreset Formation which covers much of the basin. A comprehensive synthesis of the geological history of the basin was published in 1996 by GNS Science, covering the Cretaceous-Cenozoic geology and petroleum systems of the Taranaki Basin (King \& Thrasher, 1996).

Available geological data has primarily come from hydrocarbon exploration and scientific research wells which provide lithological and biostratigraphic data in addition to other geological information collected during the well drilling and testing phase. As of 2013, there have been more than 400 wells drilled in the Taranaki Basin, with numerous sidetracks and well re-entries and extensions. Geophysical logs are collected on almost every well either by logging while drilling, or subsequent wireline logging. More than 70,000 line kms of 2D seismic data and more than $8000 \mathrm{~km}^{2}$ of 3D seismic data have been collected spanning the 
full extent of the basin (Milner et al., 2010; NZPAM, 2013). Crustal-scale seismic, gravity and magnetism studies have also been conducted exploring the basement terranes, crustal-scale faulting and deep crustal structure (e.g. Mills, 1990; Holt \& Stern, 1991; Holt \& Stern, 1994; Woodward, 1997; Stagpoole et al., 2004).

The Crown entity controlling permit and resource allocation, New Zealand Petroleum \& Minerals, has a digital database of all publicly available reports related to petroleum and mineral exploration in New Zealand (https://data.nzpam.govt.nz/GOLD/system/mainframe.asp). All scientific and commercial reports and data generated during oil and gas exploration are released through the New Zealand Petroleum \& Minerals Petroleum Report series upon becoming publically available. This process has generated a database of research regarding hydrocarbon and mineral exploration across New Zealand but primarily in the Taranaki Basin. All of this information can be downloaded from the NZPAM database ("GOLD") free of charge. This large body of research, containing over 4000 petroleum reports, covers the entire geological history of the Taranaki region.

GNS Science has created an online software package, the Petroleum Basin Explorer, containing original research, databases and data syntheses produced by GNS Science (http://data.gns.cri.nz/pbe/index.html). This includes, but is not limited to, New Zealand petroleum industry overviews, summaries of individual sedimentary basins, basin exploration histories, technical studies, and over a dozen Taranaki and East Coast Basinwide databases such as biostratigraphy and geochemical fluid properties. This software is integrated with New Zealand Petroleum \& Mineral's GOLD database.

\section{$\underline{1.4 \text { Goals and Outline }}$}

This goal of this study is to document and interpret the relationship between sediment deposition direction and extensional fault movement during the Pliocene, and examine the relative importance that the local faulting, subsidence and volcanism have individually had upon the sediment distribution during the Pliocene by interpreting channel and sediment deposition geomorphology. This is achieved through a combination of seismic interpretation of the 3D seismic volume, imaging and interpretation of seismic coherency cube slices, and incorporation of geological samples and biostratigraphic analyses. 
Two mega-channels (order of $500 \mathrm{~m}$-scale) are observed within the downthrown hangingwall block of the Cape Egmont Fault Zone, and one other mega-channel (order of $500 \mathrm{~m}$ scale) observed within the footwall block of the Cape Egmont Fault Zone, and are mapped beyond the extent of the Parihaka 3D seismic survey, using available 2D data. Older 2D seismic data from the ES89 survey are used to map the ultimate locus of deposition of the sediments that were once transported along the channel.

There is a large intrusive volcanic edifice in the study area that appears to show sedimenttransport channel redirection proximal to the crest of the intrusion. This study will document the observed patterns and explain the genesis of these features.

The primary objectives of this research are to:

1. Investigate the relationship between seismic facies/seismic coherency and sediment characteristics.

2. Determine how faulting controls the sedimentation of the Giant Foresets in the study area.

3. Determine what effect volcanic intrusives within the Northern Graben have had upon sediment transport.

\subsection{Thesis Structure}

The Thesis is structured as follows:

1. Introduction (this chapter) gives the objectives and motivation of the project and an overview of the study area.

2. Background gives a detailed description of the geological elements discussed in this study.

3. Methodology gives a description of the methods employed in this study.

4. Results details the observations and discoveries made.

5. Discussion discusses the results within the current framework of knowledge.

6. Summary discusses and summarises the findings. 


\subsection{Nomenclature}

3D Seismic Volume: 3D seismic data is generated from a set of closely spaced parallel seismic lines that measure sub-surface reflectivity. Processing techniques (based on line spacing, shotpoint and receiver spacing) convert the individual lines into a well-sampled 3dimensional volume. This volume can be "sliced" and viewed at any orientation while still displaying a well sampled seismic line.

Seismic Attributes: Seismic attributes are derivatives of a basic seismic measurement (textbook definition). Basic seismic measurements are time, amplitude, frequency and attenuation. Attributes are usually calculated and extracted from the seismic data mathematically using the basic measurements as inputs. Attributes are used to enhance interpretations beyond the information that is visually available within the seismic section or trace. Seismic coherency is an example of a seismic attribute.

Seismic Coherency: Coherency describes the similarity of adjacent traces within a specified window. This technique is used to highlight faults, sedimentary features (channels, fans etc.), and map the lateral extent of a given reflector.

Seismic Section: Seismic sections are images displaying seismic, such as a 2D seismic profile or a profile extracted from a 3D seismic volume in the vertical orientation.

Seismic Time-Slice: Seismic time-slices are horizontal displays of 3D seismic data in which all traces are displayed at a given travel time value.

Shelf-Margin Clinoforms: Clinoformal foreset sequences form as a consequence of the basinward accretion of the shelf-margin and are typically characterised by a distinctive sigmoidal shape in profile. Shelf-margin clinoforms generally span the transition from shelf to slope to basin-floor. They are usually composed of a range of lithologies from fine muds through to silts and sands.

The classical definition of a clinoform encompasses the whole sigmoidal surface running from the top-set to the dipping section, otherwise known as the foreset, through to the bottom-set. In morphological terms, the top-set represents the shelf, while the foreset is 
the slope and the flat-lying bottom-set the basin floor. The hinge-point between the top-set and foreset is considered the shelf-edge or offlap break.

Submarine Fans: Submarine fans are typically elongate, stretching from the shelf to the basin floor with a lobate fan at the down-dip end (Boggs 2006). They are typically composed of (from most shallow to deepest) incised channels, leveed channel systems, mass transport complexes, frontal splays and distal lobes (Fig. 1.2). Typically submarine fans spread outwards at the basin floor, fed by submarine canyons. Multiple closely spaced submarine channels may form coalescing fans to create a larger single fan.

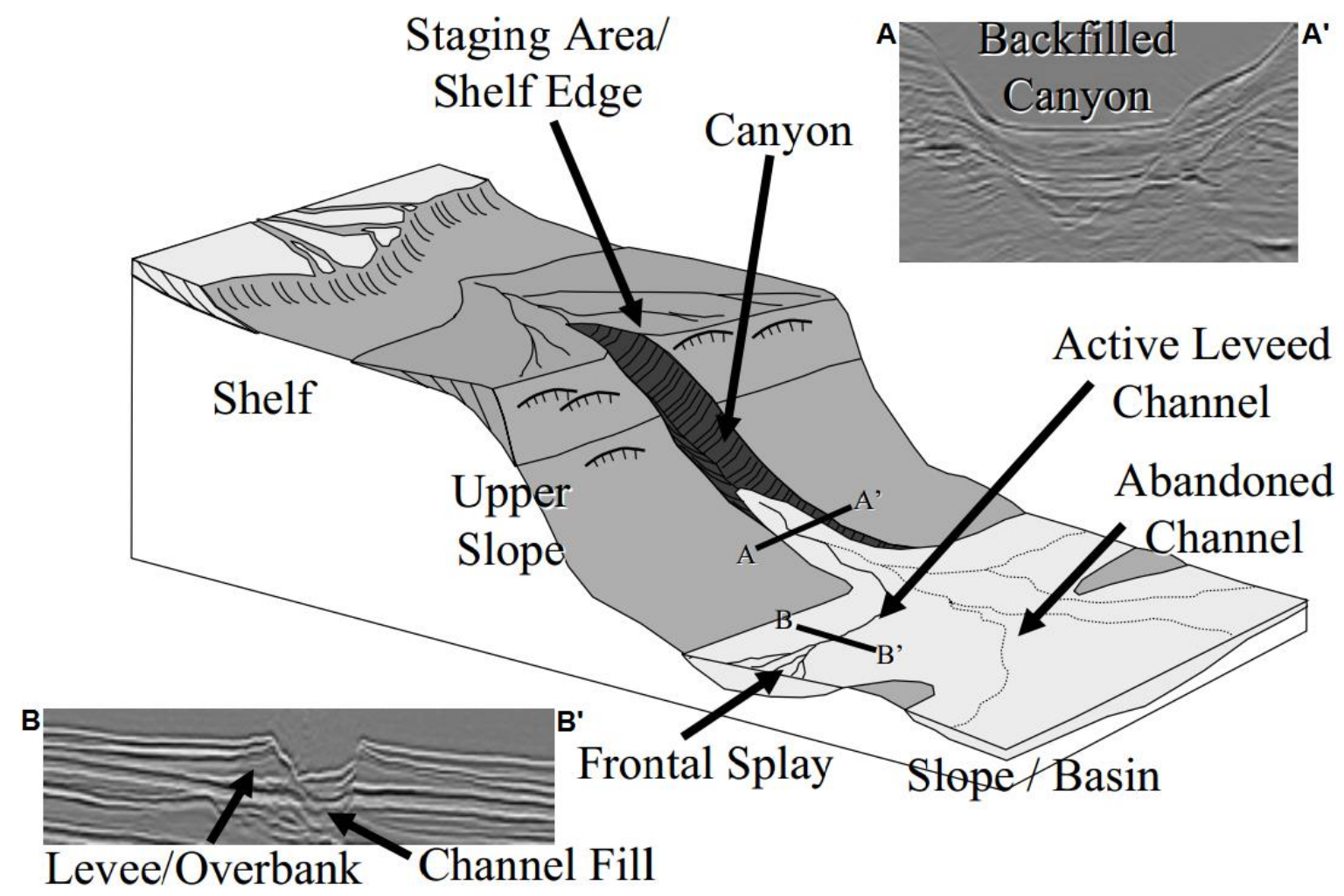

Figure 1.2: Depositional model for a submarine fan illustrating the key components and their positions within the overall system. 


\section{Page intentionally left blank}




\section{Background Chapter}

\subsection{Introduction}

The Taranaki Basin sits on the western margin of the New Zealand continental landmass, containing much of the present western shelf break. The basin evolved from a Paleogene post-rift to foreland basin during the Neogene (Stern \& Davey, 1990). Accommodation space produced by foredeep subsidence and quasi-intra-arc rifting was infilled by clastic sediment generated by continental collision to the east and south. A several kilometer thick sedimentary sequence known as the Giant Foresets Formation has steadily prograded across the basin since the early Pliocene, infilling localised depressions and extending the shelf edge by tens of kilometers (Pilar \& Wakefield, 1978).

\subsection{Setting and Tectonic History}

The New Zealand continent straddles the boundary between the Australian plate to the west and the Pacific plate to the east (Fig. 2.1). These plates interact with one another across two large, oppositely dipping subduction zones separated by a major oblique strikeslip fault. The Pacific Plate is subducted beneath the Australian plate at the west-dipping Hikurangi subduction margin to the east of the North Island. To the SW of the South Island, the Australian Plate subducts eastward beneath the Pacific Plate at the Puysegur Trench. The complex interactions of these two subduction zones are accommodated along the Alpine Fault which is a crustal-scale transform fault running $900 \mathrm{~km}$ along the western edge of the South Island.

The Taranaki Basin has evolved as a classic foreland-basin (Stern \& Davey, 1990). Extension and subsidence during the Late Cretaceous to Early Eocene was followed by compression and foreland subsidence from Late Eocene to Recent. Intra-arc extension from Late Miocene to $2 \mathrm{Ma}$, and back-arc extension from $2 \mathrm{Ma}$ to Recent in the north and middle of the basin is considered a complication to the standard rift model. The coincident compression and extension are explained by spatial variations in the tectonic regime from north to south driven by an evolving subduction zone to the east of New Zealand (Giba et al., 2010). 


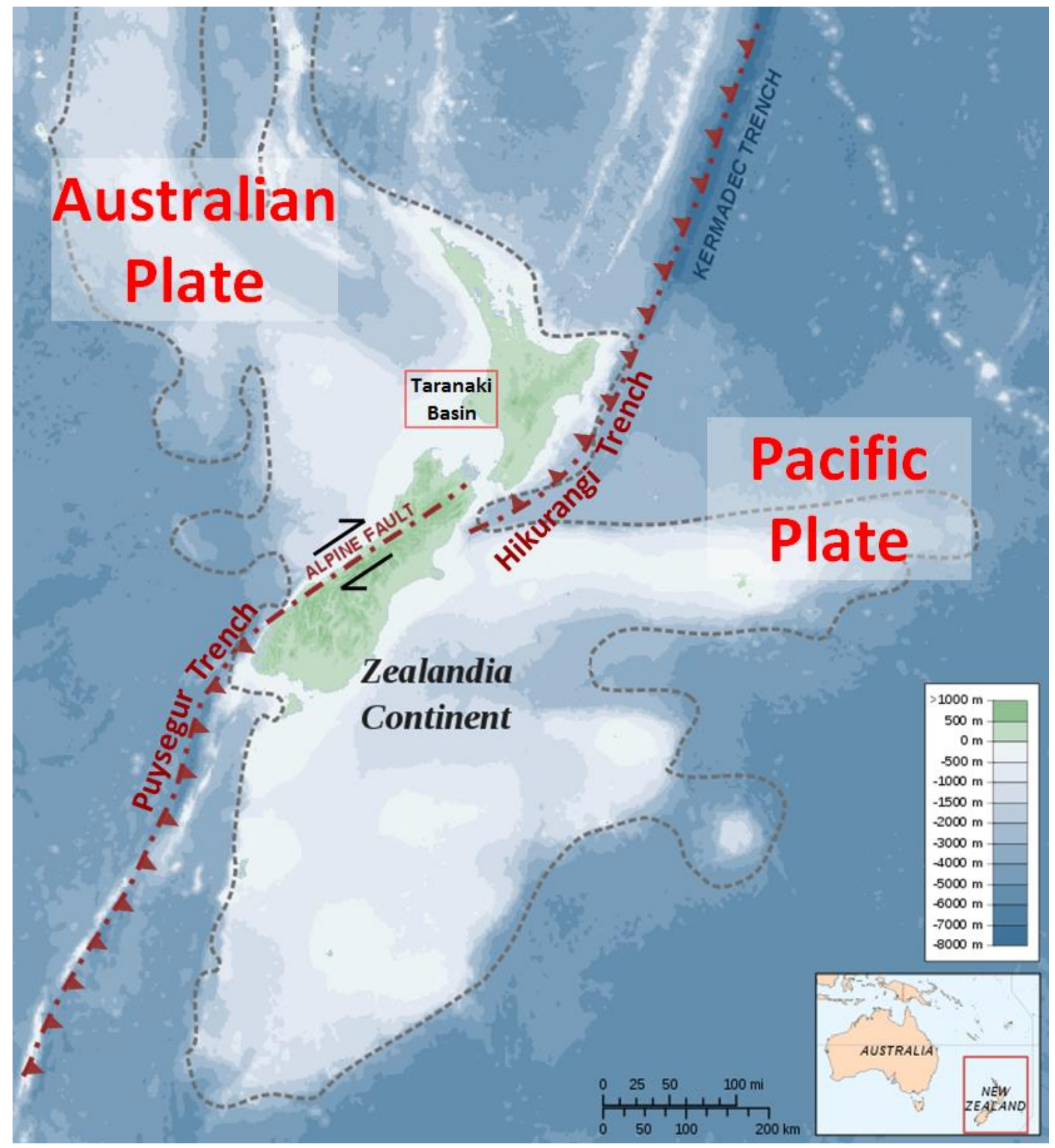

Figure 2.1: Structural elements map of the New Zealand Continent. Plate boundaries are denoted by the maroon hatched line. Elevations/water depths are indicated by varying shades of green and blue. Figure is modified after http://en.wikipedia.org/wiki/Geology_of_New_Zealand.

The Taranaki Basin is a thick Cretaceous-Cenozoic sedimentary wedge, bounded to the east by the Taranaki Fault. The basin sits mainly offshore on the western edge of New Zealand's continental landmass. The Taranaki Basin consists of two main structural elements (Fig. 2.2). The Western Platform is a stable, $\sim 150 \mathrm{~km}$ wide shelf containing $\sim 5000 \mathrm{~m}$ of relatively simple, unfaulted sedimentary section. The Eastern Mobile Belt is a highly faulted band of deformation with a complex tectonic history, expressed as a broad, N-S elongate region. 


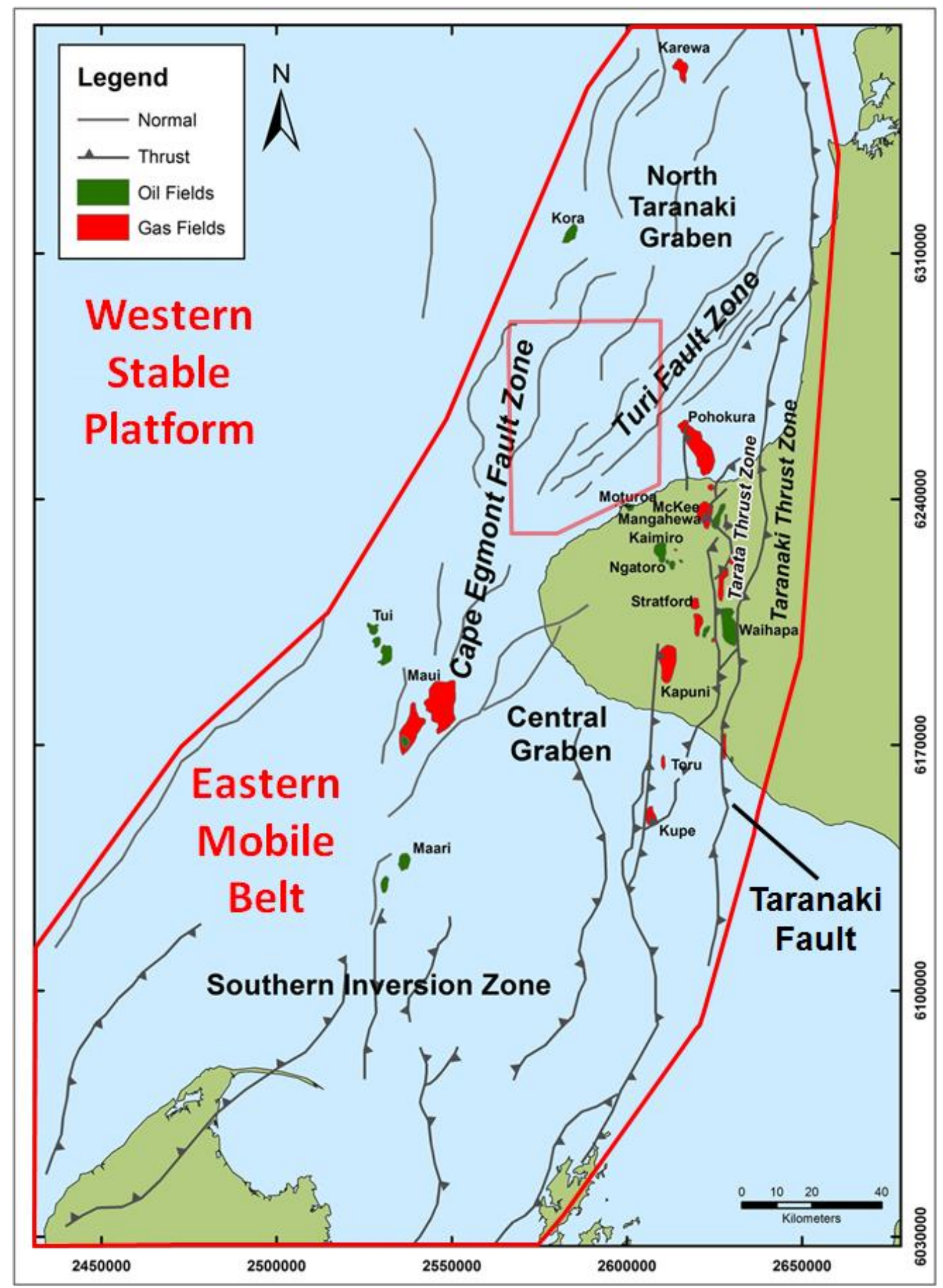

Figure 2.2: Structural elements map of the Taranaki Basin. The study area is indicated by transparent red polygon. 
The northern and central parts of the Eastern Mobile Belt, known as the North Taranaki and Central Grabens, are currently extending, while the southern area, called the Southern Inversion Zone, is shortening. The North Taranaki Graben, the location of this study, is an $\sim 80 \mathrm{~km}$ wide faulted depression with up to $\sim 11 \mathrm{~km}$ of sedimentary section. The basin is underlain by Paleozoic metasedimentary basement rocks, intruded by basaltic plutons of Devonian, Carboniferous and Cretaceous age (Muir et al., 2000).

The incipient basin formed as a rift margin on the landward side of the Gondwana margin during the separation of the Australian and New Zealand continental landmasses (King, 2000). Isolated, normal fault-bounded Late Cretaceous rift sub-basins were infilled with clastic material derived from surrounding exposed basement blocks (Thrasher, 1991). These rift basins are now situated in the south and east of the basin (King \& Thrasher, 1996). Rifting diminished as the locus of extension shifted to the opening of the Tasman Sea, ceasing entirely by the latest Paleocene (King, 2000).

Following this period of rifting, from the Eocene to the Oligocene the Taranaki Basin was a passive continental margin undergoing subsidence due to thermal contraction. Eocene strata appear unfaulted by coeval faulting. From as early as the Late Cretaceous, passive marine transgression occurred as fault- and thermally-controlled passive margin subsidence exceeded sedimentation (King \& Thrasher, 1996). Significant accommodation space was generated which allowed several km-thick clastic sedimentary sequences to be deposited, burying the sub-basins and resulting in compaction and drape over pre-existing structure. Passive margin subsidence of the Taranaki Basin during the Paleogene is superimposed on a broader trend of regional subsidence of the New Zealand continental landmass (King, 2000). Exposed land areas were minimal throughout New Zealand during the Oligocene, and sediment availability declined.

The Taranaki Basin transitioned to a foredeep basin with the southward propagation of the Hikurangi subduction margin east of New Zealand, starting in the northern basin (King, 2000). This initiated thrust faulting and regional compression on the Taranaki Fault as early as 40-43 Ma, causing the eastern basin to undergo foredeep subsidence (Holt \& Stern, 1994; Stagpoole \& Nicol, 2008). Flexural deformation of the continental crust on a wavelength of 150 km generated bathyal water depths of 600-1500 m. Compression on the eastern 
margin led to the re-activation of many of the Cretaceous sub-basin-bounding faults as reverse faults (Reilly et al., 2014). Compressional structures were formed within the Taranaki Basin, particularly in the south and east.

Thrust faulting on the eastern margin waned during the late Miocene, starting at the northern tip of the Taranaki Fault at 20 Ma (Stagpoole \& Nicol, 2008). Compression transitioned to extension in the northernmost part of the basin by $\sim 12 \mathrm{Ma}$ as the Hikurangi subduction zone underwent clockwise rotation driven by slab roll-back and migration of the southern termination of the subduction zone (King, 2000; Nicol et al., 2007; Giba et al., 2010). Extension has waned in the North Taranaki Graben since $4 \mathrm{Ma}$, however it continues around the western Taranaki Peninsula and Maui field to the SW. Further south, the Southern Inversion Zone has had $7 \mathrm{~km}$ of shortening since the Early Miocene (King \& Thrasher, 1996).

\section{North Taranaki Graben}

The North Taranaki Graben is a NE-SW triangular, elongate, extensional feature bounded to the east by the NE-striking Turi Fault Zone and to the west by the NNE-striking Cape Egmont Fault Zone (Fig. 2.2). The North Taranaki Graben sits offshore to the N-NW of the Taranaki Peninsula and has undergone tectonism and subsidence that is distinct from the rest of the Taranaki Basin. Biostratigraphy indicates that the North Taranaki Graben was at lower bathyal (1000-1500 m) water depths during Late Miocene to Early Pliocene while the majority of the basin was between upper bathyal and shelfal water depths (50-600 m) (King \& Thrasher, 1996).

The North Taranaki Graben is considered a back-arc extensional feature, although it deviates from the conventional back-arc model in some aspects (King \& Thrasher, 1996 pp. 128). Extensional movement on the Turi and Cape Egmont Fault Zones has occurred during the Late Miocene to dominantly Pliocene, with a southward migration of faulting and coincident andesitic volcanism. Andesitic volcanism of the Mohakatino Volcanic Centre began at $16 \mathrm{Ma}$, followed by normal faulting which began in the northernmost Taranaki Basin at $12 \mathrm{Ma}$ (Giba et al., 2010). Although both faulting and volcanism share a common causal mechanism and spatio-temporal correlation, neither process controls the timing, location or activity rate of the other (Giba et al., 2013). 
The graben has been inferred to have progressively opened in a fan-like fashion due to clockwise rotation of the Hikurangi subduction margin to the east (Giba et al., 2010). The southern termination of extension migrated southwards in geologically instantaneous 100$150 \mathrm{~km}$ episodes at c. 12-8 and $4 \mathrm{Ma}$ (Fig. 2.3). The hinge-point between extension and compression currently sits close to the Maui Field, SW of the Taranaki Peninsula. The extensional tectonic regime migrated southwards episodically during the Late MiocenePliocene, generating 1-3 km of extension within the North Taranaki Graben, with the main period of extension in the North Taranaki Graben occurring during the Pliocene. Proximal to the study area, up to $2 \mathrm{~km}$ of extension has been accommodated on the Cape Egmont Fault Zone and Turi Fault Zone.

The $\sim \mathrm{N}$-S oriented Cape Egmont Fault Zone is $15-20 \mathrm{~km}$ wide and characterised by a leftstepping, en-echelon fault pattern, with large slip movements tending to concentrate on single east-dipping faults at any one location (Nodder, 1993). Despite being an en-echelon fault system, there does not appear to be much, if any, lateral movement accommodated on these fault-segments. The en-echelon pattern is believed to be related to the reactivation of Cretaceous basement faults at non-optimal orientations (Giba et al., 2012).

The Turi Fault Zone is composed of multiple NE-SW striking, quasi-linear dip-slip faults (King \& Thrasher, 1996). Movement within the fault zone tends to be spread across stacked, subparallel faults which each take up a small portion of the total extension and progressively step basement and the overlying sedimentary section down to the NW.

The Mohakatino Volcanic Centre is a series of more than 20 individual submarine andesitic stratovolcanoes and related intrusive volcanic complexes which trend NNE/SSW along the central axis of the North Taranaki Graben (King \& Thrasher, 1996). Three intrusive complexes are present within the Parihaka 3D, with oldest to youngest running north to south (Luke, 2013). 


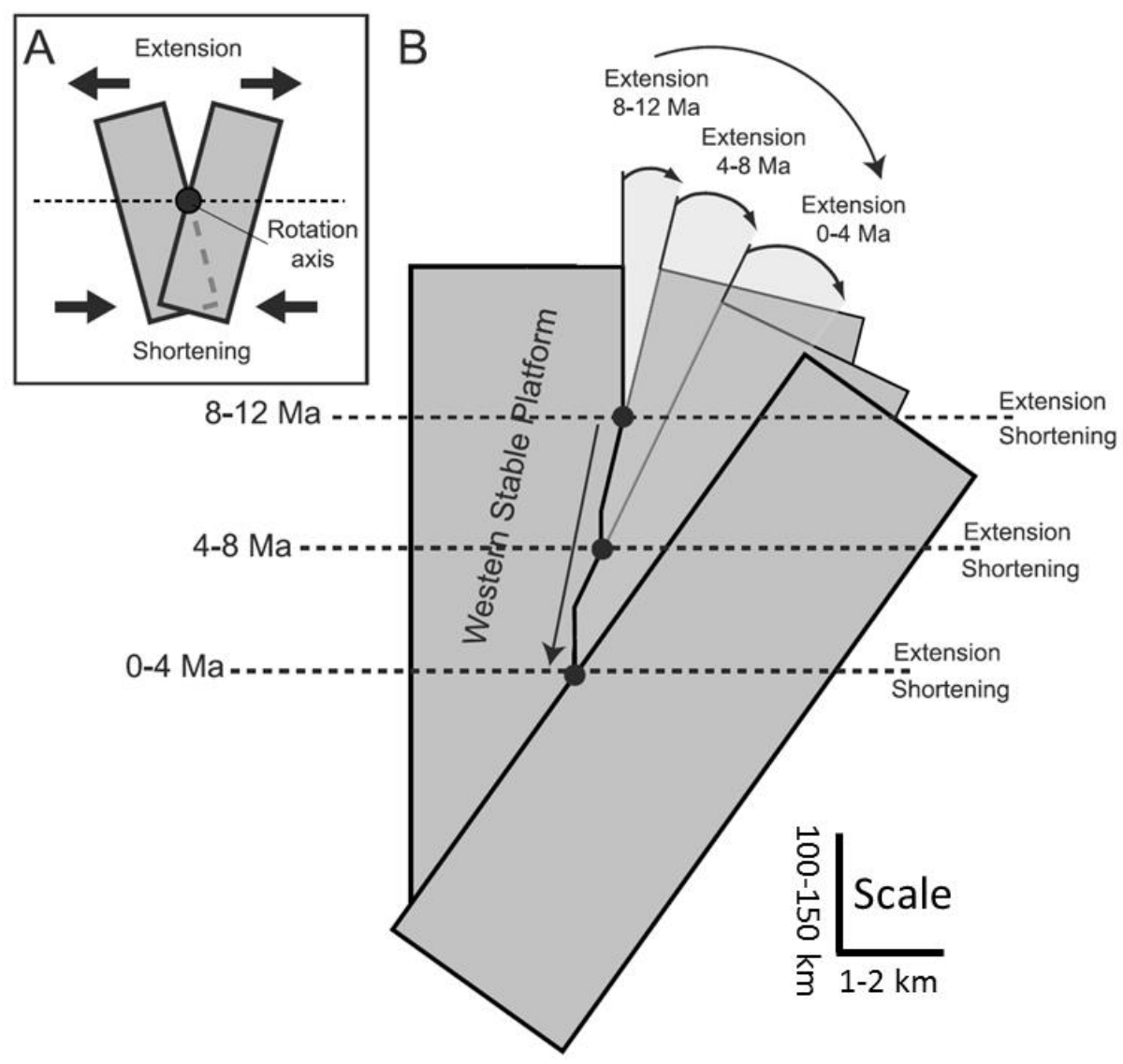

Figure 2.3: Generalised schematic of the block rotation model illustrating the southward migration of the rotation axis between extension and shortening in the Taranaki Basin through the Late Miocene-Recent. Figure is modified after Giba et al. (2010).

\section{The Parihaka Fault}

The Parihaka Fault sits within the central to northern portion of the Parihaka 3D survey. The fault is the largest bounding structure on the western margin of the North Taranaki Graben, with a length of about $50 \mathrm{~km}$ and total (Cretaceous-Recent) vertical displacements of up to $1800 \mathrm{~m}$ (Giba et al., 2012). Displacement on the main fault segments of up to $1450 \mathrm{~m}$ have occurred since reactivation at $\sim 3.7 \mathrm{Ma}$. The fault has four distinct segments of between 8 and $15 \mathrm{~km}$ length at the Early Pliocene level, while the fault is near-continuous at the Cretaceous level (Figs. 2.4b-c). The fault again merges at the Pleistocene level, forming two or three distinct segments (Fig. 2.4d). This is attributed to a complex history of faultactivation and displacement accrual during the Late Cretaceous-Early Eocene striking N-S, followed by reactivation during the Early Pliocene striking NE-SW in a regionally rotating stress field (Giba et al., 2010). The en-echelon character of the fault system is considered a product of reactivation at a non-optimal orientation (Giba et al., 2012). 

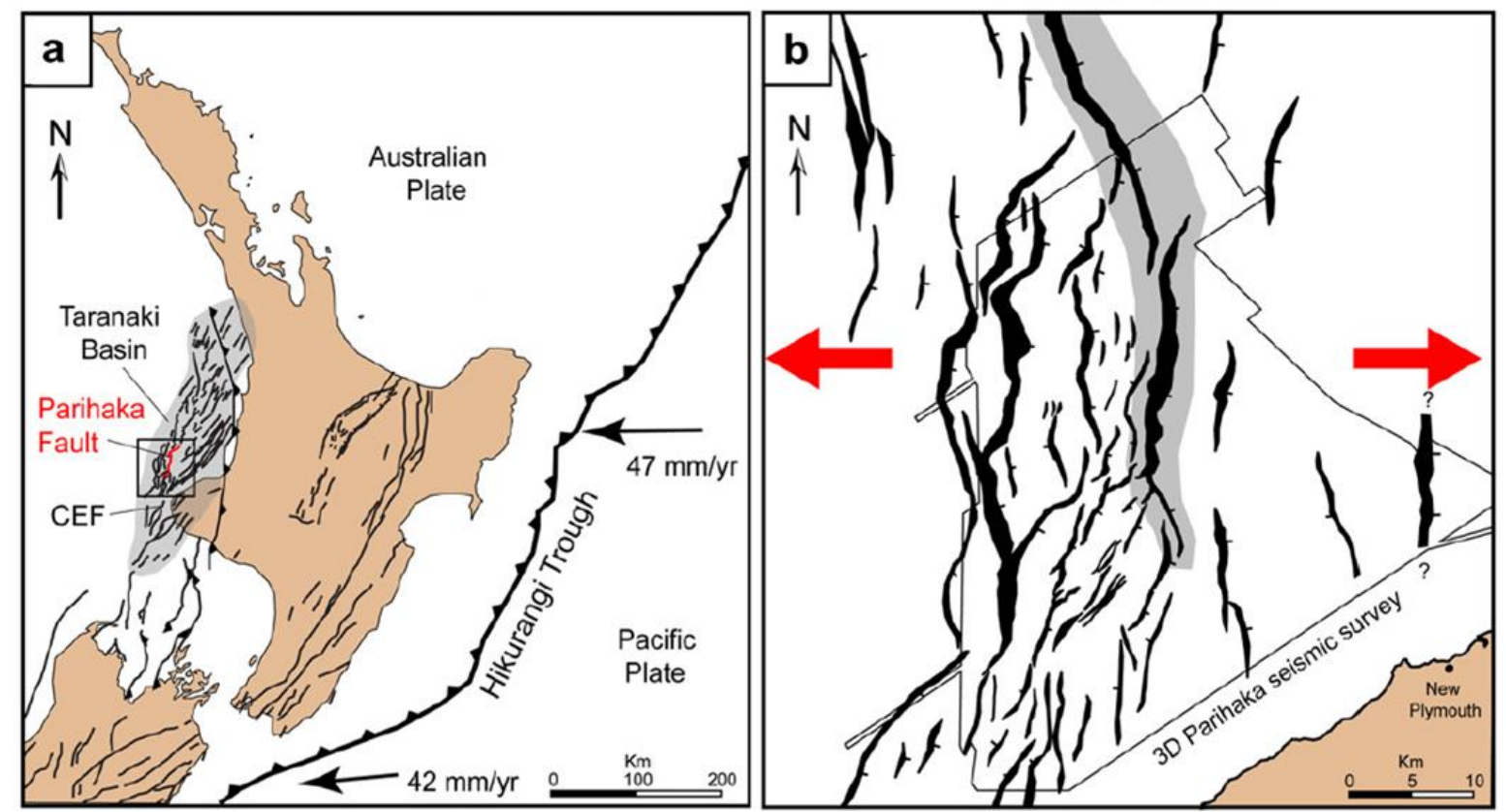

\section{Early Pliocene - oblique reactivation}
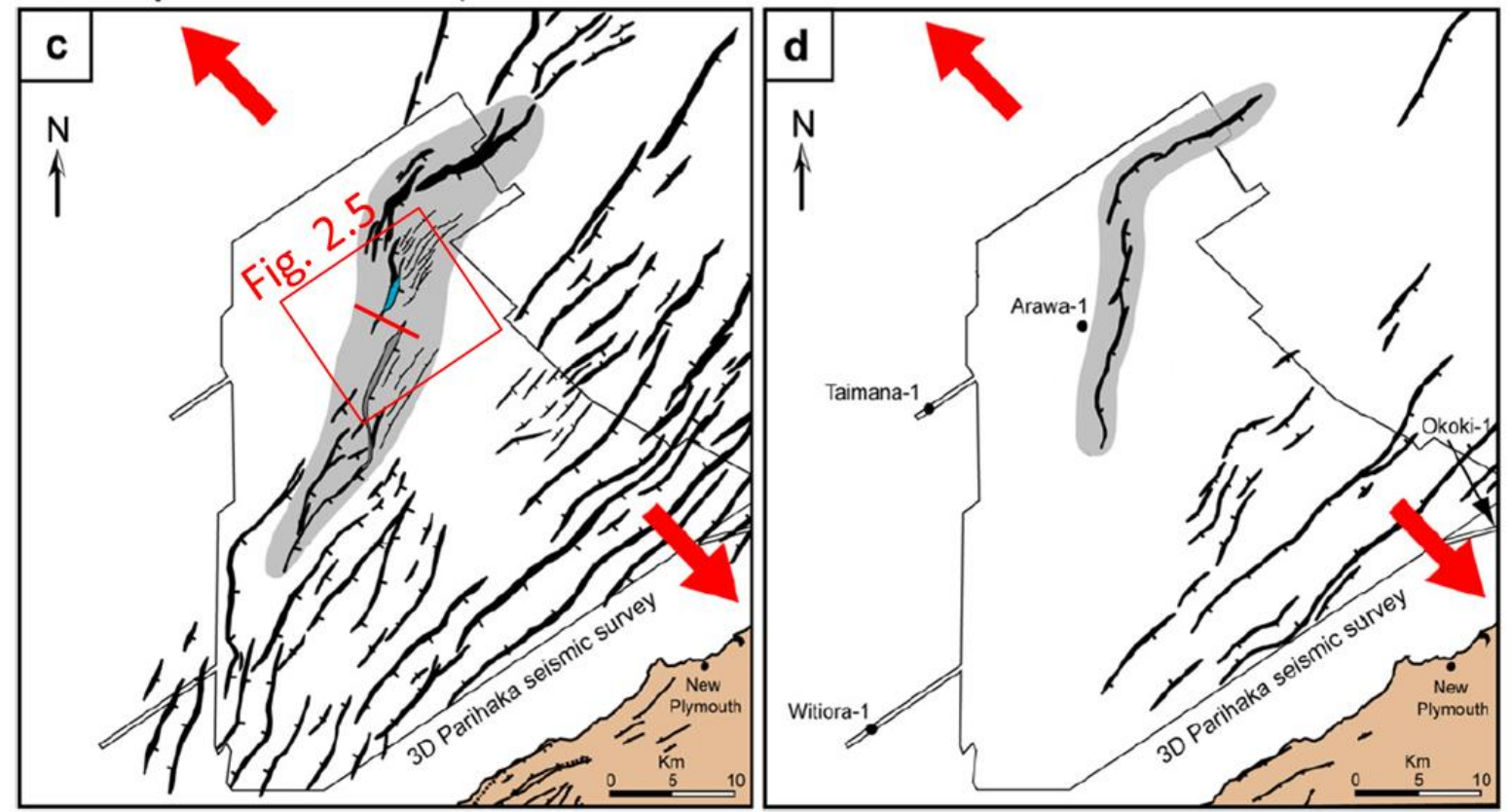

Figure 2.4: Parihaka Fault position relative to the Parihaka 3D seismic survey at the level of the (b) Late Cretaceous, (c) Early Pliocene, and (d) Pleistocene. The general position of b-d is shown in panel a. Direction of extension is denoted by bold red arrows. The location of figure 2.5 shown by the red box/line in panel c. Figure is modified after Giba et al. (2012).

Giba et al. (2012) find that the Parihaka Fault is "hard-linked" to a continuous, pre-existing fault at depth, and "soft-linked" at shallow depths by relay zones where the fault steps to the left in an en-echelon pattern (Figs. 2.5a-f). Hard-linkage refers to faults connected on the scale of the map or cross section in use (Walsh \& Watterson 1991). Soft-linked faults are 
those connected through ductile strain of the rock volume which separates them. Softlinked faults appear to be disconnected at the scale of the map or cross section in use. In the case of Parihaka Fault the relay zones have undergone rotation in order to maintain linkage between the footwall and hangingwall. No appreciable brittle deformation is evident in cross-section and coherency slices, supporting the soft-link model for stress propagation across the relay zones (Fig. 2.5). Deformation in these zones is likely accommodated by ductile drag, sub-seismic-resolution faults and fault-ramp rotation.

The reactivation of the Parihaka Fault began c. 3.7 Ma with an extension orientated NW-SE, at $\sim 45^{\circ}$ clockwise to the Cretaceous extension direction and initial fault orientation (Giba et al., 2012). Displacement analysis of the Parihaka Fault shows that the post-Miocene movement was greatest on the northern segments, with a smaller throw on the central portion of the southern segment (Fig. 2.6). Extension was concentrated on the NE-SW striking fault segments, which were orthogonal to the extension direction, and more favourably oriented. Vertical displacement approaches $1600 \mathrm{~m}$ on the northern-most segment, while throws on the central portion of the southern fault segment lie between 200-800 m. The growth of the fault segments in the early Pliocene was geologically instantaneous in terms of both segment lengths and relay zone dimensions. Growth was then accomplished by progressive displacement accumulation on the dominant fault surfaces and increasing rotation of relay ramps (Giba et al., 2012).

Fault shape in cross-section alternates between straight and sigmoidal (Fig. 2.7). These variations are controlled by the alignment between the fault strikes of the Cretaceous and Pliocene segments (Giba et al., 2012). The dominant faults tend to take a sigmoidal form in areas where the younger fault segments are poorly oriented to the Cretaceous basement fault but orthogonally oriented relative to the direction of extension. Close alignment between Cretaceous and Pliocene fault-strikes tend to produce a straight fault in crosssection. 


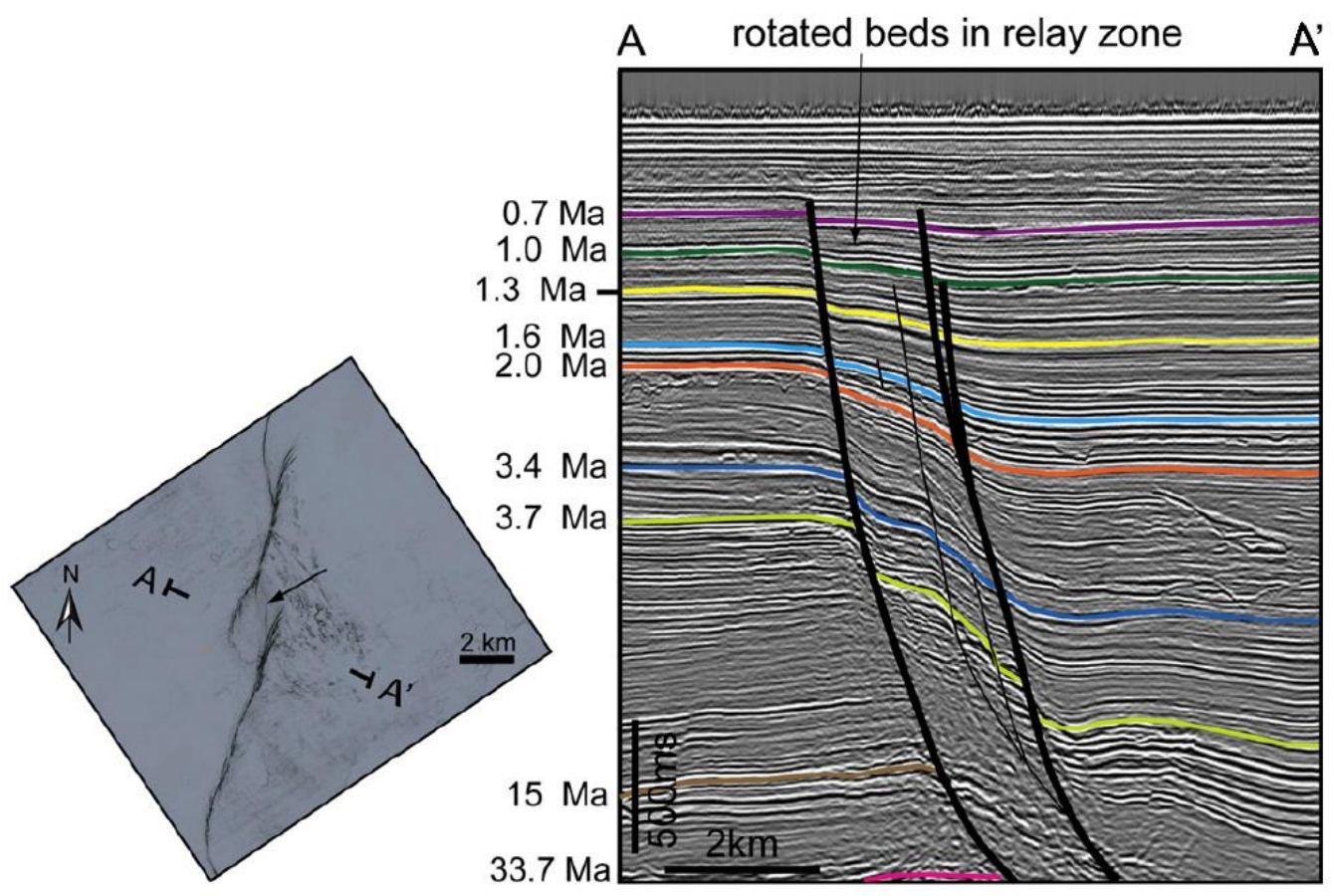

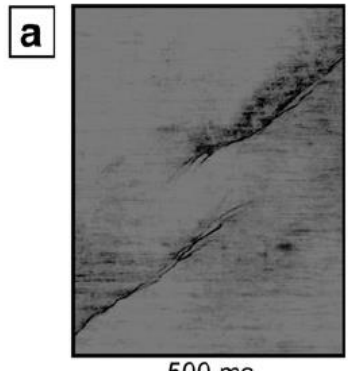

$500 \mathrm{~ms}$

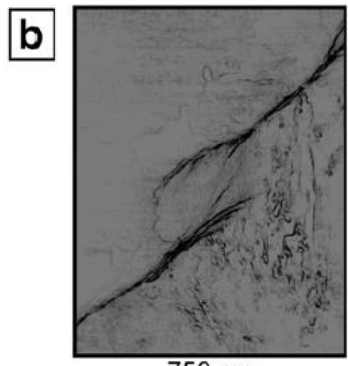

c

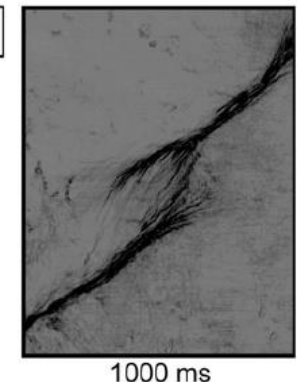

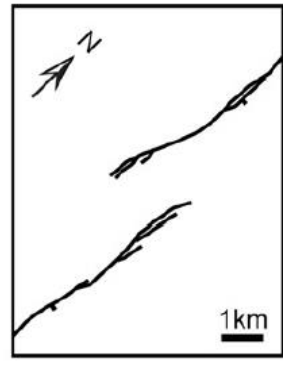

$1 \mathrm{~km}$
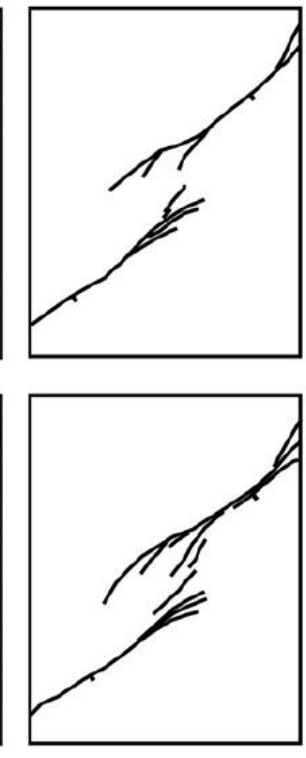

d

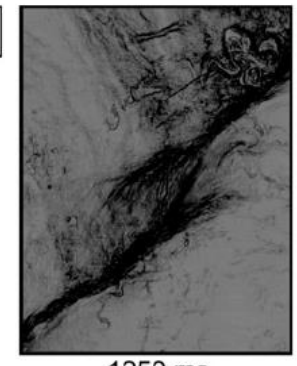

$1250 \mathrm{~ms}$

e

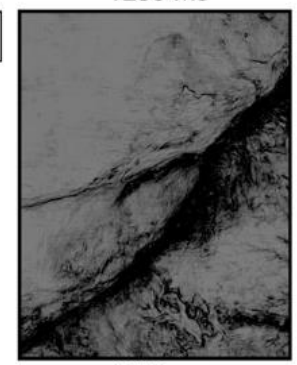

$1500 \mathrm{~ms}$

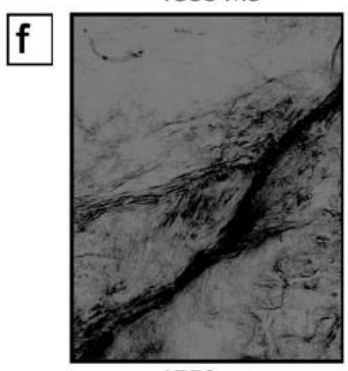

$1750 \mathrm{~ms}$
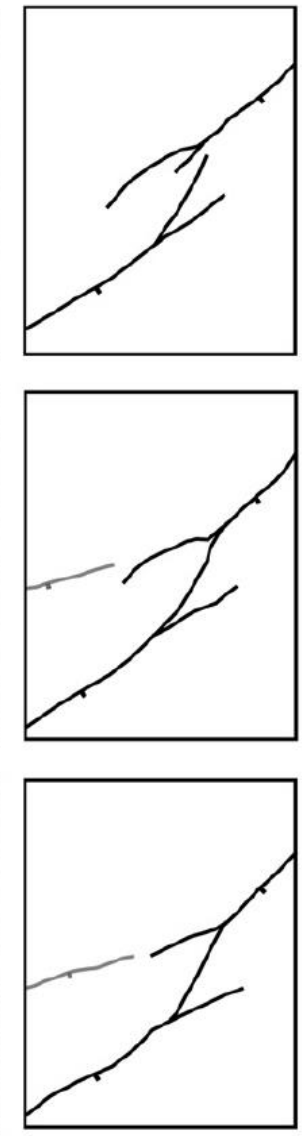

Figure 2.5: Coherency cube slice (top left) and seismic section (top right) of the Parihaka 3D seismic survey illustrate a relay zone within the Parihaka Fault. The varied structure of the relay zone with depth is illustrated with increasing time below the top of the seismic volume (a-f) in the coherence domain (left) and schematically (right). See figure 2.4 for coherency cube and seismic section location map. Figure is modified after Giba et al. (2012). 

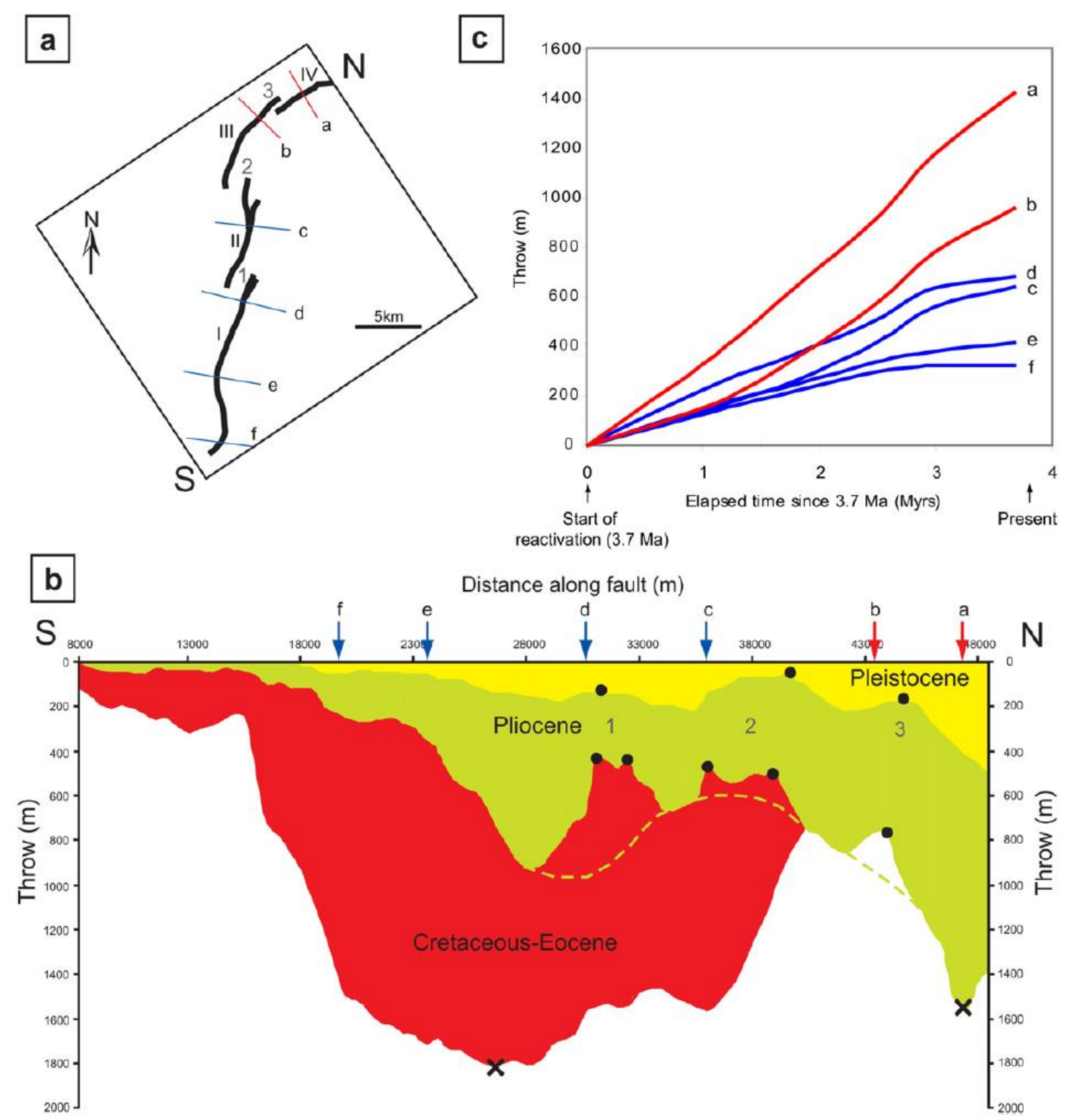

Figure 2.6: Panel (a) shows the fault locations with the position of the four fault sections (I-IV) and fault reconstruction cross-sections (a-f). The amount of throw on each reconstructed fault crosssection for the periods Cretaceous-Eocene (red), Pliocene (green) and Pleistocene (yellow) are shown in panel $b$. The amount of throw on each reconstructed fault cross-section since the start of reactivation (3.7 Ma) is shown in panel c. Figure is modified after Giba et al. (2012).

Small scale $(<120 \mathrm{~m})$ antithetic faults have formed parallel to two main segments within the hangingwall block (Fig. 2.7). The locations of these antithetic faults are attributed to the complex sigmoidal shape of the main fault in some areas (Giba et al., 2012). Antithetic faults are postulated to have accrued total displacement in no more than $0.3 \mathrm{Ma}$, starting near the initiation of faulting at $\sim 3.7 \mathrm{Ma}$ in order to accommodate volumetric strains. 

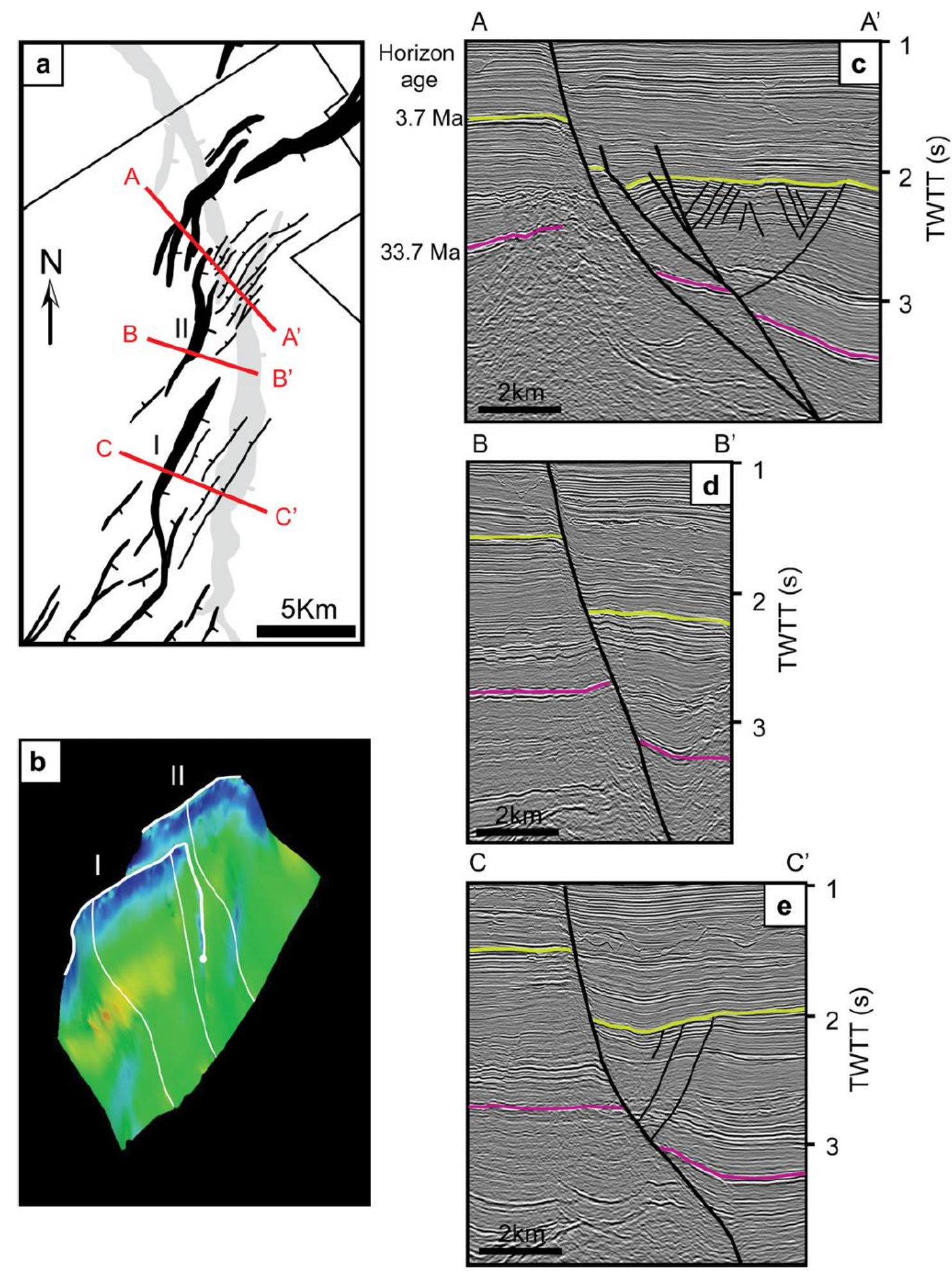

Figure 2.7: Sigmoidal and straight fault shapes of segments within the Parihaka Fault. a) Map shows the trace of the Parihaka Fault and antithetic faults in the early Pliocene (bold and thin black lines) and the associated Cretaceous basement fault (light grey). b) 3D model of fault segments I and II with dip angle indicated by colour (blue = high angle, red = low angle). c-e) Seismic sections A-A' and C-C' illustrate a sigmoidal fault shape of the main fault surface (bold black line) and the occurrence of minor antithetic faults (thin black lines) in the hangingwall. Section B-B' shows a straight fault trace in seismic section and the absence of minor antithetic faults in the hangingwall. 


\subsection{Stratigraphy}

The sedimentary section within the Taranaki Basin can be divided into four units affected by four distinct tectonic regimes (Fig. 2.8). These are broadly:

1. Late Cretaceous syn-rift sequence.

2. Paleocene-Eocene late-rift and post-rift transgressive sequence.

3. Oligocene-Miocene foredeep and distal sediment starved shelf and slope sequence and Miocene regressive sequence.

4. Plio-Pleistocene regressive sequence.

The tectonic evolution of the Taranaki Basin is explained in "Setting and Tectonic History" (this chapter).

Nascent rift sub-basins across the south and east of the Taranaki Basin were initially infilled by Late Cretaceous terrestrial sands, muds and coals of the Rakopi Formation (Thrasher, 1991). In the northern Taranaki Basin discreet N-S oriented sub-basins were infilled during this time. These carbonaceous sediments form the primary source rocks of the petroleum system in the basin. Progressive subsidence within the sub-basins allowed a marine transgression which swept southwards from the open embayment in the northwest basin (now Deepwater Taranaki Basin). Terrestrial in-fill deposits of the Rakopi Formation were overlain by marginal and fully marine units of the North Cape Formation (Thrasher, 1992a; Wizevich et al., 1992). Together, the Cretaceous-aged sediments form the syn-rift sequence known as the Pakawau Group.

Extension slowed during the Paleocene-Eocene and rifting on sub-basin bounding faults diminished. Post-rift relaxation of the lithosphere produced basin-wide subsidence, generating accommodation space and allowing a marine transgression to flood the basin. Rift sub-basins were infilled with sediment and inactive bounding faults were buried beneath an influx of sediment. Up to 2500 m-thick sequence of non-marine, paralic and marine sediments was deposited, with an open embayment in the north of the basin, to the NW of the present day location of the study area (King \& Thrasher, 1996). The northern basin was dominantly marine, while the southern basin experienced non- and marginalmarine conditions, with the shoreline position oscillating periodically, but generally 


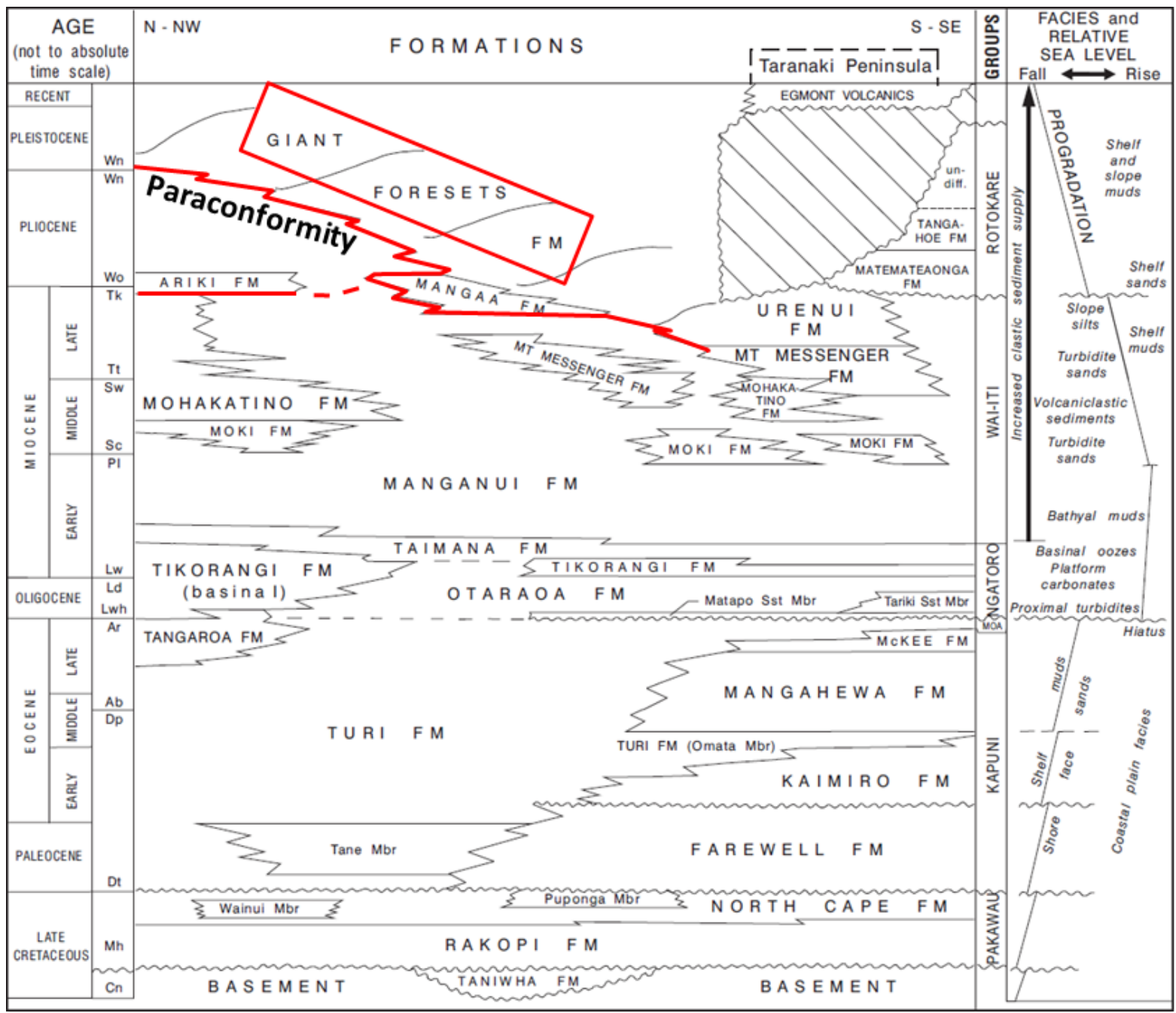

Figure 2.8: Taranaki stratigraphic column showing the location of the key formations/groups/events and their international and New Zealand stages. The paraconformity sits beneath the Mangaa and Giant Foresets Formation in the North Taranaki Graben. Figure is modified after King \& Thrasher (1996).

migrating southwards through the Eocene. The interbedded coastal plain and marginal marine conditions known as the Kapuni Group were gradually overlapped by the fully marine, fine-grained sediment of the Moa Group. These inter-fingered sedimentary packages are important source, reservoir and seal components of the Taranaki petroleum system.

As the New Zealand continental landmass continued to subside during the Oligocene, subaerially exposed landmasses were diminished and a regional marine transgression took place (King, 2000). Sediment sources were depleted and sediment-starvation was common across most of the continental shelf. This created conditions which were conducive to widespread deposition of shelfal carbonates. The Tikorangi Formation is a regionally 
extensive, up to $240 \mathrm{~m}$ thick, Oligocene-aged siliciclastic-carbonate to carbonate limestone unit that has correlative units across several New Zealand sedimentary basins (Hood et al., 2003). The northern Taranaki Basin sat at shelf-upper bathyal depths during this time, with an open embayment to the NW of the study area.

Compression and uplift of the New Zealand landmass from the mid-late Miocene to the south and east of Taranaki provided an influx of clastic material, infilling the eastern foredeep depression (Kamp et al., 2004). Up to $2000 \mathrm{~m}$ of rock uplift in the central North Island as well as compression along the Alpine Fault generated an influx of clastic sediment to the adjacent King Country, Wanganui and Taranaki Basins (Guilford \& Stern, 2004). An initial period of progradation during the mid-Miocene to early Pliocene in the King Country, Wanganui and southern Taranaki Basin was followed by second phase of shelf progradation from the mid-Pliocene-Pleistocene in the central and northern Taranaki Basin (Hansen \& Kamp, 2004b). The migration of sediment was blocked on the basin's eastern margin by the Patea-Tongaporutu and Herangi Highs (Fig. 2.9). Sediment was instead directed along the Toru Trough from the south.

More than 3500 m of sediment was deposited, particularly in the east of the Taranaki Basin where foredeep subsidence was most pronounced, during the Oligo-Miocene. Sediment was swept from the proto-coast to bathyal marine depths (200-1500 m), which prevailed across much of the basin during the initial period of regional contraction. Multiple discrete submarine turbidite deposits formed during the Miocene, creating some of the Taranaki Basin's reservoir units (e.g. Mount Messenger Formation) (Mills, 2002).

Extension in the northern basin from the Late Miocene onwards created a depression that has continued to capture sediments since the Earliest Pliocene. Large volumes of sediment sourced from the uplifted landmass to the east and south were preferentially funnelled into the depression, starving areas in the north and west of the basin. Kilometer-scale clinoformal beds known as the Giant Foresets Formation (GFF) rapidly prograded the shelf edge to the north and northwest. By the late Pliocene, the rate of sedimentation outpaced the rate of extension within the North Taranaki Graben. Deposition of the GFF within the North Taranaki Graben outpaced subsidence by $3 \mathrm{Ma}$, overtopping the graben footwalls and prograding the shelf break to the N/NW (Fig. 2.10). 


\section{North Taranaki Graben}

The North Taranaki Graben has a distinct tectonic history for the period Late MioceneRecent, which generated localised bathyal water depths and a distinct sedimentary section within the graben. The genesis of the North Taranaki Graben began with the onset of volcanism at $\sim 16 \mathrm{Ma}$ and extensional faulting at $\sim 12 \mathrm{Ma}$.

At the base of the North Taranaki Graben stratigraphic section are the Late Miocene Mohakatino and Manganui Formations which are present in the onshore and northern offshore Taranaki Basin (Fig. 2.8; King \& Thrasher, 1996). The Mohakatino Formation is a tuffaceous and volcaniclastic sand, mud and silt unit related to sub-marine volcanism that occurred in the graben from 16 Ma to 2 Ma. The Manganui Formation is a deep-water hemipelagic mudstone succession which is widespread across much of the Taranaki Basin.

A paraconformity sits directly above the Mohakatino/Manganui Formations across a large portion of the North Taranaki Graben accounting for up at least 1.5 Ma of missing time in places (Fig. 2.8; King \& Thrasher, 1996). This highly condensed or missing section was caused by a period of sediment starvation across large parts of the northern Taranaki Basin. Nondeposition has been connected to the capture of thick accumulations of sediment within the King Country and Wanganui basins east and south of the North Taranaki Graben respectively (Fig. 2.9; Kamp et al., 2004). The sedimentary sections in the study area at the location of Arawa-1 and Taimana-1 do not contain the paraconformity; however these wells are technically located on the graben margin (Diamond Shamrock Exploration, 1984; ARCO, 1992).

The Ariki Formation is a calcareous marl unit that straddles the paraconformity in the North Taranaki Graben. The formation is named for a marl first described within Ariki-1, though it has since been observed in several other wells (e.g. Wainui-1, Tangaroa-1, and Te Kumi-1). The formation has a strongly calcareous character and a distinctly high planktic percentage. The formation is a condensed, terrigenous sediment-starved unit deposited at bathyal depths (King \& Thrasher, 1996). 


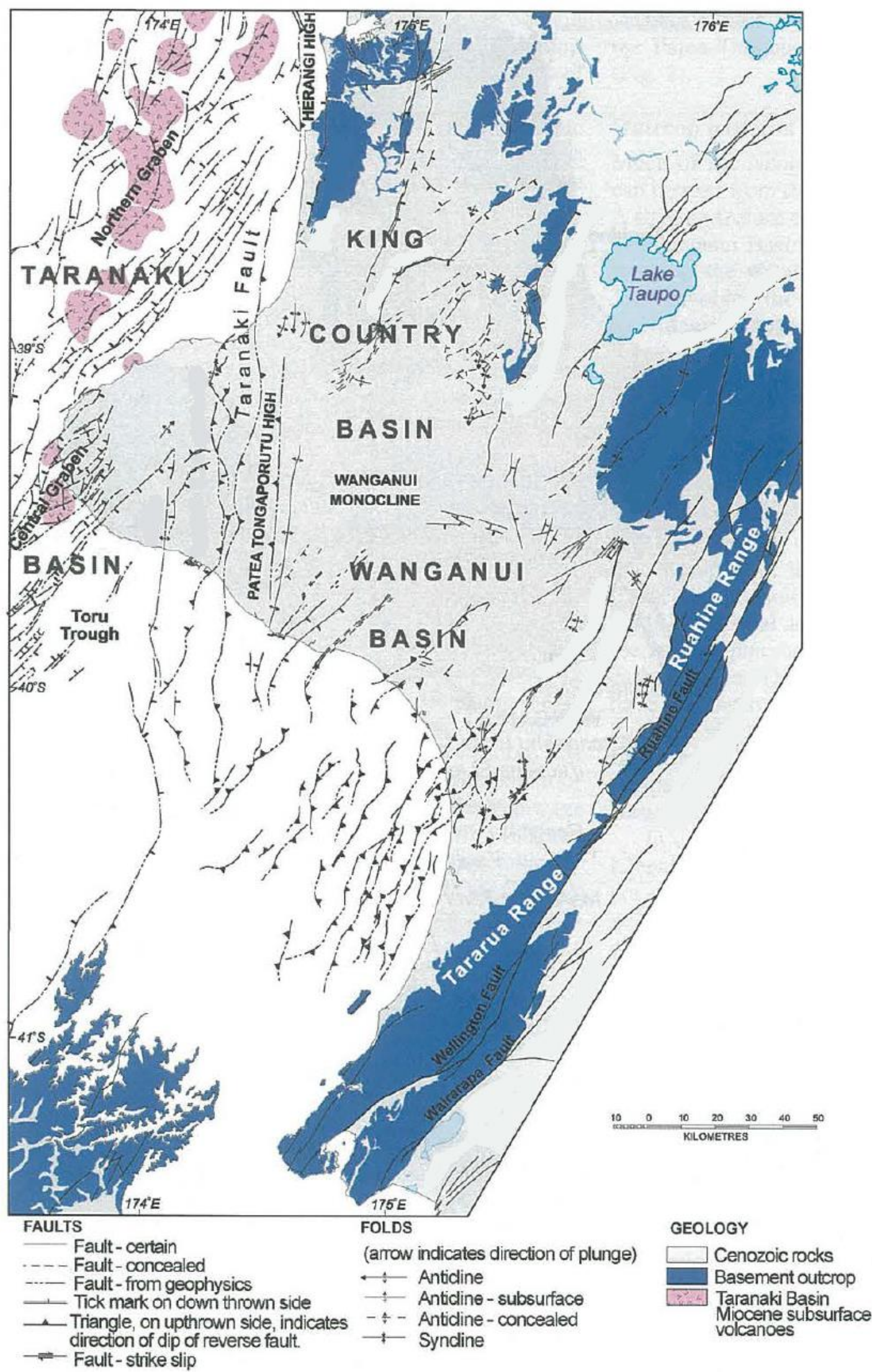

Figure 2.9: North Island structural features map showing the location of the Wanganui, King Country and Taranaki Basins. The Patea-Tongaporutu and Herangi Highs sit at the eastern margin of the Taranaki Basin. Figure is modified after Kamp et al., (2004). 
Overlying the paraconformity is the Mangaa Formation, which is a basin-floor sandstone unit. The formation is a turbidite package of fine to very fine grained sandstones with thicknesses up to $600 \mathrm{~m}$ over two main intervals within Mangaa-1, where it was first described (King \& Thrasher, 1996). The unit has a wedge geometry, thinning to the NE along the graben axis. Seismic profiles indicate that the formation was deposited from south to north during the Early Pliocene and represents the initial sedimentary infill of the North Taranaki Graben following the hiatus (Hansen \& Kamp, 2004a).

\section{Giant Foresets Formation}

The GFF sits at the top of the sedimentary section throughout the North Taranaki Graben and across a large portion of the central basin and NW Western Stable Platform. In some areas the GFF directly overlies the Mohakatino/Manganui Formations separated by the paraconformity, while in other areas the GFF is separated from the paraconformity by the Ariki or Mangaa Formations (Fig. 2.8). The exact basal age of the GFF is diachronous due to the strongly progradational nature of the formation, however it is generally no older than $\sim 4$ Ma (Hansen \& Kamp, 2004a). The age of the upper bounding surface is the seafloor and therefore present day.

The GFF was generated by rapid uplift of the New Zealand landmass along the Alpine Fault and Hikurangi subduction zone since the Miocene (Kamp et al., 2004). Sediment was sourced from the south, with the Patea-Tongaporutu and Herangi Highs on the Taranaki eastern margin acting as barriers to sediment flow from the east. Sediment of the GFF was transported across the Wanganui Basin and into the North Taranaki Graben and Western Platform in a broadly N/NW direction. Basin infill was rapid, with some wells in the central and northern areas showing evidence of water depths decreasing from mid-lower bathyal $(600-1500 \mathrm{~m})$ to mid shelf $(50-100 \mathrm{~m})$ in under $2 \mathrm{Ma}$, even as the graben underwent extensional faulting (e.g. Arawa-1, Taranga-1, Awatea-1) (ARCO Petroleum, 1992; Murray \& de Bock, 1996; Morgans, 2006). The timing of sediment-infill is diachronous, with the shelf break advancing across the basin from approximately southeast to northwest through the late Miocene to Pleistocene (Kamp et al., 2004). 

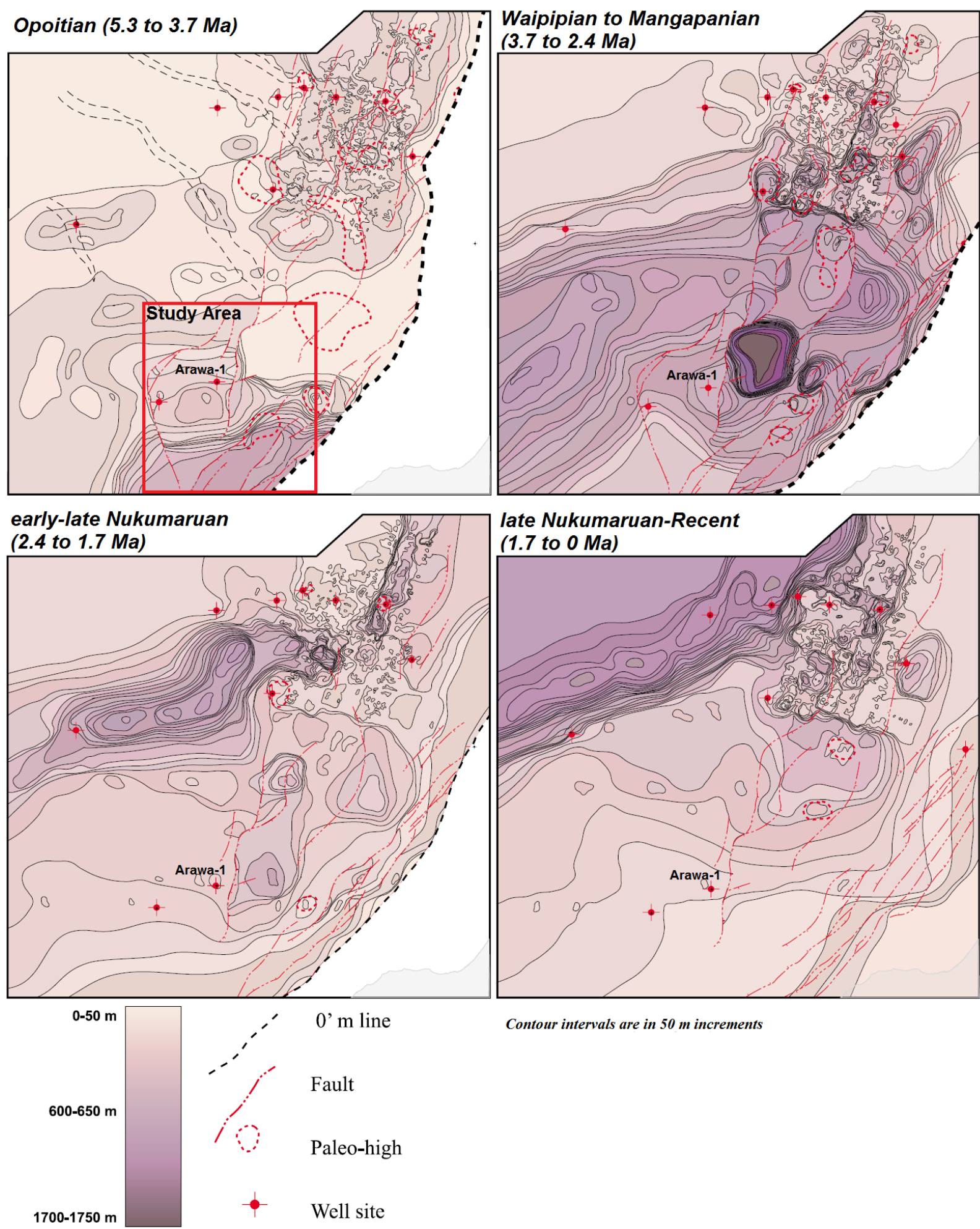

Contour intervals are in $50 \mathrm{~m}$ increments

Figure 2.10: Isopachs showing the depositional pattern and sediment thickness of the Giant Foresets Formation by New Zealand Stage (see appendix figure C. 6 for New Zealand stage ages). Thickness is in metres. The " $0 \mathrm{~m}$ " line is the point at which non-deposition and/or erosion occurred during that period. Figure is modified after Hansen \& Kamp (2002). 
The GFF is a shelf-margin clinoformal unit spanning the transition from shelf to slope to basin floor. The overall shape of the GFF is sigmoidal, as are its internal components. The unit is comprised of fine muds, silts and sands with irregular volcaniclastic intervals. The topsets are often fossiliferous and pebbly due to their relatively shallow and proximal depositional environment. There are several correlative units to the GFF across the western North Island

The GFF has a distinctive seismic facies character for which the unit is named. There are four distinct parts, defined by seismic character (Beggs, 1990; Hansen \& Kamp, 2002) (Fig. 2.11):

- Top-sets: This part is defined by sub-parallel, sub-horizontal, moderately continuous reflectors. Lithologies tend to be cyclic sandstones, muddy siltstones and shell-beds consistent with deposition in neritic (shelf) conditions.

- Progradational foresets: Offlapping, moderately continuous and dipping in a basinward direction at $1-3^{\circ}$. Lithologically fine-grained mudstones and muddy siltstones are interpreted to be deposited on the continental slope (outer shelfupper bathyal).

- Degradational foresets: These are lower amplitude, chaotic and discontinuous, steeply-dipping (up to $10^{\circ}$ ) reflectors. Lithologies are also heterogeneous and chaotic, ranging from dominantly mudstone to sporadic sandstone and conglomeratic beds. Although this part represents similar conditions to the progradational foresets, they are reflective of a different depositional mechanism, namely downslope mass movements. Units may deeply incise underlying strata.

- Bottom-set: These are sub-horizontal to slightly inclined, variably continuous, lowmoderate amplitude reflectors consisting of variable sandstone and mudstone. Depositional environment is basin-floor at bathyal water depths.

Beggs (1990) argues that each component was formed in response to interplay of sediment supply and accommodation space. When sediment supply exceeds the accommodation space available on the continental shelf, sediment is transported to greater water depths beyond the shelf break, producing the foreset and bottom-set packages. Sea level lowstands tend to produce foresets and bottom-sets due to the lack of accommodation space, 


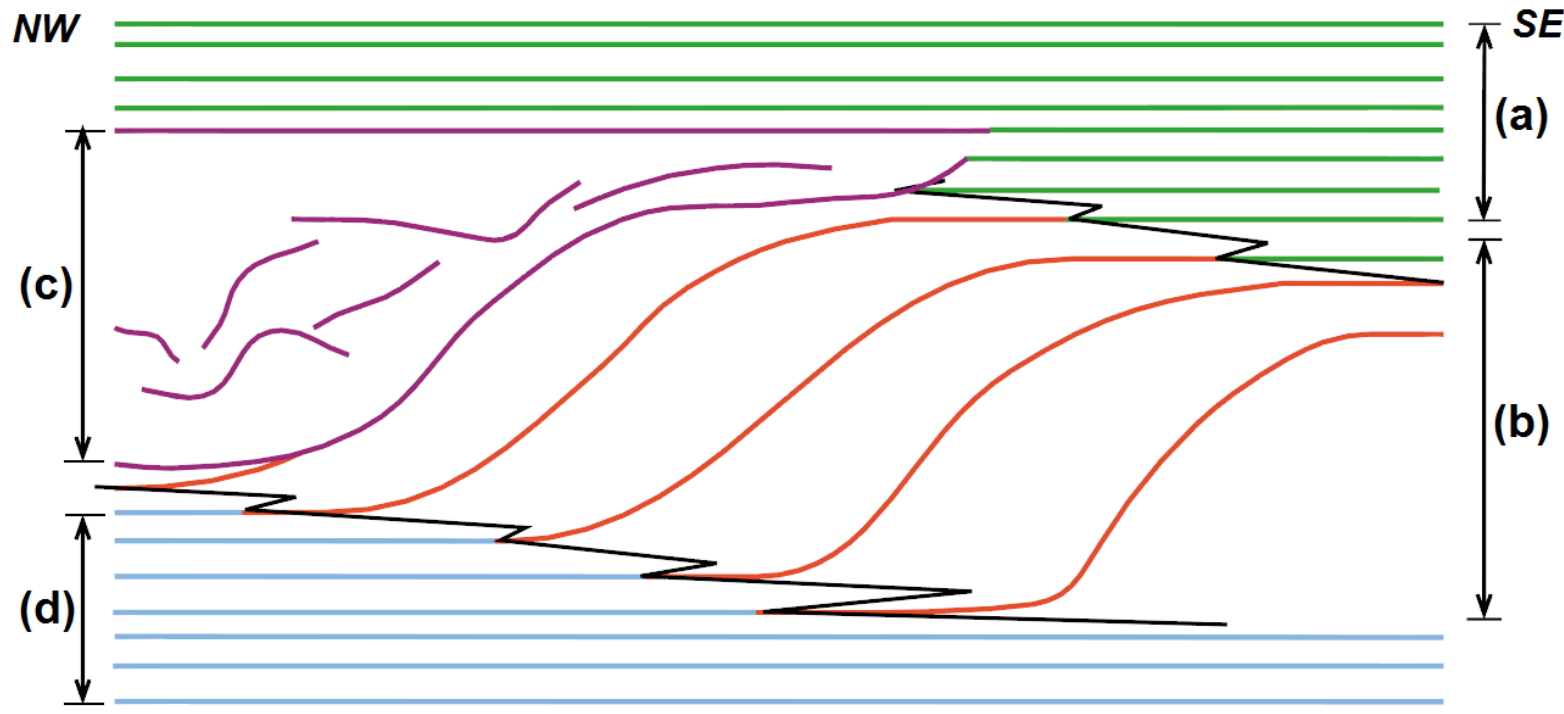

Figure 2.11: A schematic illustration of the divisions within the Giant Foresets Formation. The relative position of the components within the shelf-slope-basin setting run from proximal (right) to the sediment source to distal (left). The divisions are (a) top-sets, (b) progradational foresets, (c) degradational foresets, and (d) bottom-sets. Figure is modified after Hansen \& Kamp (2002).

whereas highstands tend to produce top-sets because of the increase in accommodation space at shelfal water depths. Foresets differentiate between progradational and degradational based on the steepness of the slope. Where the slope angle exceeds $\sim 3^{\circ}$, slope instability causes mass failures and secondary movements of sediment to greater water depths, creating the distinctive degradational foresets, as well as aggrading bottomsets in the form of deep marine fan deposits.

The foresets can be divided into distinct seismic units separated by boldly reflective bounding surfaces. Hansen \& Kamp (2002) recognise 60 distinct units in the northern Taranaki Basin, however there are likely an even greater number stretching to the extreme north and west reaches of the basin. Each seismic package contains (or contained) top-set, (progradational or degradational) foreset and bottom-set components. Cyclicity is observed in the GFF which can be tied to fluctuations in sea level (Beggs, 1990). The majority of sedimentation and progradation of the GFF is likely to have occurred during sea level lowstands when high volumes of sediment were transported beyond the shelf break and captured at greater water depths. The bold reflectors which bound successive foreset packages are inferred to be the result of partial lithification during sea level highstands when minimal sediment was delivered to the slope and basin floor (Beggs, 1990). 


\section{Fine-Scale Features}

The Giant Foresets Formation has been well studied and observed across much of the basin (Pilar \& Wakefield, 1978; Beggs, 1990; Hansen, 2003; Hansen \& Kamp, 2002, 2004a, 2004b, 2006a, 2006b). However the fine-scale details of sediment transport mechanisms are not well documented. This is largely due to the lack of hydrocarbon accumulations within the formation which has led to it being largely overlooked and treated as "overburden" in most instances. Where it has been studied in greater detail, the use of 2D seismic data has only allowed for the large- and medium-scale features to be interpreted.

The use of a high-quality, modern 3D seismic volume, and a post-processing coherency cube volume derived from the aforementioned 3D seismic volume allows for the fine-scale detail of the Giant Foresets Formation to be observed in both the vertical and horizontal dimensions.

\section{$\underline{\text { 2.4 Seismic Data }}$}

\section{Parihaka 3D Seismic Survey}

The $1520 \mathrm{~km}^{2}$ Parihaka 3D seismic survey was acquired from January 12 to February 24, 2004 by Veritas DGC on behalf of POGO New Zealand (Veritas, 2005). Acquisition was completed in 43 days using the Veritas Viking II, with an array of eight 4500 metre streamers spaced at 100 metres recorded shots from dual alternating airguns. This allowed a high-fold sub-surface illumination which contributed to very high quality seismic data. Data were recorded to 6.144 seconds with a sampling interval rate of $2 \mathrm{~ms}$ (Appendix fig. C.1). The data was processed through Kirchhoff pre-stack time migration.

As part of the work plan commitments of the PEP51558 Joint Venture, the Parihaka 3D survey was reprocessed by WesternGeco in 2011/2012. Final deliverables included poststack time migration and post-stack depth migration (WesternGeco, 2012).

\section{Parihaka 3D Coherency Cube}

A coherency seismic data cube was created for the reprocessed 2012 Parihaka 3D post-stack time migration volume using OpendTect. The settings used during post-processing are listed in appendix figure C.2. 


\section{ES89 2D Seismic Survey}

The ES89 seismic survey was conducted in former Petroleum Prospecting Licenses 38439, 38451 and 38452 in the northern Taranaki Basin by Western Geophysical Company on behalf of Stewart Petroleum Company New Zealand (GECO NZ, 1989). The survey was conducted during April/May 1989, with 1503 line kms of 2D seismic data collected. The survey acquisition parameters are contained in appendix figure C.3. No processing report is available for this survey, and only raw migration SEG-Y is currently publically available.

\subsection{Wells}

Four wells are present in the immediate study area with 5 additional wells situated offshore proximal to the study area, all of which are hydrocarbon exploration wells (Appendix table D.1). This provides excellent geological and geophysical control for the stratigraphic section of interest to this study. The Parihaka 3D is directly tied to the four wells sitting within the study area (Arawa-1, Okoki-1, Taimana-1 and Witiora-1). Okoki-1, Taimana-1 and Witiora-1 are each tied to the survey by a single swath line as wide as the CDP footprint of the survey. The CDP footprint ranges between 400-550 m depending on "feathering" of the seismic streamers being towed behind the boat - that is, the effect currents had on pulling the streamers off centre. Arawa-1 sits in the central area of the survey, within the footwall block on the western side of the Parihaka Fault. Reports utilised in this study for the key wells in the study area are listed in appendix tables D.2 to D.5. 


\section{Page intentionally left blank}




\section{Methodology}

\section{Introduction}

Interpretation of seismic data is a fundamental tool in discovering the medium- (10's of kms) to large-scale (100's of kms) geological history of a basin (Bacon, Simm \& Redshaw, 2003). It is important to oil and gas explorers and earth scientists alike because of the high level of sub-surface detail available in seismic data that cannot be obtained by any other means. The seismic interpretation process allows geoscientists to investigate and understand the structural and sedimentary evolution of an area by mapping and reconstructing key intervals within the sedimentary section. Central to this process is the use of well data which gives information about sediment age, depositional environment and characteristic geophysical properties that guide the interpretation and give physical context to the seismic data.

Coherency data analysis is a relatively new development, only becoming widely utilised in the last two decades (Bahorich and Farmer, 1995). It differs from conventional 2D and 3D seismic data in that it is capable of highlighting finely detailed (less than one km-scale) geological structures not easily obtained in conventional seismic data. Together seismic and coherency data provide the ability to investigate the geological history of an area from a basin-wide scale, to a sub-kilometer scale. In combination, 3D seismic volumes and their post-processed coherency attribute volumes allow for the generation of sharp sub-surface images that give geoscientists more geological detail than was previous attainable.

This section provides an overview of the various practical steps undertaken throughout this seismic interpretation of the Pliocene section within the Parihaka 3D and ES89 2D seismic surveys. Seismic horizon picks of several bounding and intra-formational seismic reflectors within the Pliocene-aged clinoformal foresetting sequence are made. This interpretation leads to the production of coherency slices, depth grids, isochore maps and seismic sections, and allows for the reversal and visualisation of the effects of sedimentation, faulting and compaction. The use of 3D seismic and processed coherency cube data allows for the clear imaging of the fine $(<\mathrm{km}$-scale) sediment transport features within the GFF. Older vintage 2D data from the ES89 seismic survey traces observed geological features beyond the extent of the Parihaka 3D into the main depocentre to the NE. Grids, isochores and key seismic 
sections were generated in order to visualise and interpret the kilometer-scale details of the GFF. Coherency cube time-slices were produced from flattened horizons to study the fine (less than one km-scale) details of the GFF.

\section{Experimental Set-Up}

Visualisation of the seismic interpretation and coherency cube data is completed using The Kingdom Software package v8.8 (henceforth Kingdom). This program is multi-disciplinary, allowing the user to complete all steps required during a seismic interpretation. Seismic data loading and visualisation is included as part of " $2 d / 3 d P A K$ ", the basic seismic display and manipulation Kingdom module. Biostratigraphic data was entered using the "EarthPak" module which enables the user to display composite well data types directly onto vertical seismic sections. Any type of biostratigraphic data (as well as many other data types not used in this study) can be displayed on vertical seismic sections along the wellbore where the well intersects the seismic section.

Initially, the Parihaka 3D seismic survey and ES89 2D seismic survey were loaded into Kingdom. The coherency cube data was loaded as an additional data type within the Parihaka 3D survey. Well locations and basic well information such as water depths, reference elevations and total well depths were added.

Next, an up-to-date working set of well data for the main offset wells in the study area was loaded into the project. This consisted of time-depth profiles, deviation curves, lithostratigraphic determinations and biostratigraphic age and paleoenvironmental determinations (in the form of depth ranges and individual picks). The full sets of data and reports utilised in this study are included in appendix tables D.2 to D.5.

\section{New Zealand Petroleum \& Minerals GOLD Database}

Comprehensive well data types, including well reports and enclosures, scanned logs and digital log data were downloaded from the New Zealand Petroleum \& Minerals GOLD database. Some data presented in this thesis and employed in the interpretation stage became open file in February 2014, when Todd Energy and New Zealand Oil \& Gas relinquished Petroleum Exploration Permit 51558. At the time of publishing, all data utilised in this study was open-file and publically available. 


\section{Seismic Data}

The Parihaka 3D and ES89 2D seismic surveys were utilised in this study. The 2012 reprocessed pre-stack time migration volume of the Parihaka 3D survey was loaded as per the load-sheet instructions (Appendix fig. C.4). The coherency cube volume, processed using OpendTect, was loaded as an additional data type of the Parihaka 3D survey. This used the same loading method as the coherency data SEG-Y had the same byte locations for the trace, common depth point and inline/crossline.

A loadsheet for the ES89 2D seismic survey was unavailable; therefore the EBCDIC headers of the SEG-Y files were investigated for the correct byte locations for loading into the Kingdom project. An example of the EBCDIC header for an ES89 line is included as appendix figure C.5. SEG-Y header visualisation was completed using the SeiSee v. 2.16 .1 software package.

\section{Wells}

Four wells directly tied to the Parihaka 3D seismic survey were used in the interpretation stage of this thesis. These wells are Arawa-1, Okoki-1, Taimana-1 and Witiora-1 (Appendix table D.1), each of which was an oil and gas exploration well. Arawa-1 is situated near the centre on the Parihaka 3D seismic survey and provides the key well control for this study due to its optimal location, and the comprehensive set of well data collected during drilling. The remaining three wells were tied to the Parihaka 3D survey by a single 400-550 m-wide swath line. Because the wells are situated beyond the extent of the Parihaka 3D, an extended inline was collected by the seismic vessel which collected a single seismic line out to the well location. Due to the limited width of the swath line, these wells are utilised to corroborate the geological and geophysical information collected during the drilling of Arawa-1. Because these wells are tied to the Parihaka 3D survey the geological data they provide can be used to understand the spatial variations in the seismic data across the entire study area resulting from geological variations. 


\section{Formation Tops}

Observed lithological variations and characteristic biomarkers allow the well operator to make an informed estimate of the boundaries of the penetrated formations. The formation tops used in this study, and their sources, are presented in appendix table D.2. These interpreted formation boundaries form another core component of this seismic interpretation. Tying the formation tops to prominent reflectors strengthens the temporal constraints on the interpretation.

\section{Biostratigraphy}

Biostratigraphic determinations are made by identifying micro- and macro-faunal assemblages deposited within sediment. Biostratigraphic data provides age and paleoenvironmental constraints to the penetrated sequence. These data are a crucial component in orienting the study with respect to the age of the horizons and intervals of interest as well as the environmental conditions under which they were deposited. There is also an inherent element of diachronicity with each of the picked horizons, which could be evaluated by using biostratigraphic data from several wells. Foraminiferal age and environment dating is most commonly used for marine sediment such as those deposited during the Pliocene within the study area.

Well completion reports and ancillary reports and enclosures were reviewed for all available biostratigraphic data for the key wells within the Parihaka 3D. Publicly available results that were utilised in this study and loaded into the Kingdom project are summarised in appendix table D.3. Age determinations were commonly provided in the New Zealand stage units format. The Cretaceous-Cenozoic International and New Zealand stages over the Middle Miocene-Recent period are presented in appendix figure C.6.

\section{Time-Depth Data}

All key wells had a vertical seismic profile collected during the wireline logging phase of the drilling operation. The time-depth data for these wells ensures that the seismic data displays correctly in relation to the composite log data, which is entered in depth format. The timedepth curves are also used to convert the seismic data from the time domain to the depth 
domain. The vertical seismic profile data was also used to apply a depth conversion to the seismic data.

The time-depth curves were extracted from the well completion reports for the four key wells tied to the Parihaka 3D (Appendix table D.4; Appendix fig. C.7). The results were placed in a simplified tabulated format for loading into the Kingdom project.

Time depth data are collected by firing a source at the surface and having a receiver within the borehole at a known depth. Shots are repeatedly fired with the receiver at multiple depths. The relationship between travel-time from source to receiver and the known vertical separation between the two points allows for determination of the vertical velocity structure of the sedimentary section at that location. This can be laterally extrapolated from the borehole location, provided reasonable geological assumptions are made. See section 5. $x$ for a discussion of the seismic time-depth data and their application within this study.

\section{Deviation Curves}

Deviation curves are available for the four key wells in the study area (Appendix table D.5). Deviation curves are commonly used to convert measured depths to true vertical depths. Most composite data types are provided in measured depth, but the data are displayed on seismic sections in true vertical depth so it is important to be able to convert between these two depth types to ensure that well data are being displayed at the correct location along the borehole on the seismic section.

\section{Seismic Interpretation}

This study follows widely accepted structural seismic interpretation methods as outlined by Bacon et al., 2003 (pp. 65-95). Interpretation of the Parihaka 3D and ES89 2D seismic surveys was performed in The Kingdom Software version 8.8 (64bit) 2d/3dPak-EarthPak features on a Z800 workstation. The following steps were taken for the seismic interpretation:

1. Parihaka 3D seismic volume was loaded to the Kingdom project using the values provided in the WesternGeco PSTM Loadsheet and SEG-Y EBCDIC header (WesternGeco, 2012; Appendix fig. C.4). 
2. ES89 2D seismic survey lines were loaded to the project using the EBCDIC header of the SEG-Y files (Appendix fig. C.5).

3. Biostratigraphic, time-depth and deviation data was loaded to the well entries for the four wells tied to the Parihaka 3D survey (Appendix tables D.3 to D.5).

4. The seafloor reflector ("Seafloor") was picked based on its intersection with the Arawa-1 well on a $250 \times 250$ inline/crossline spacing. The picked seismic horizon was verified at Taimana-1 and Witiora-1 and Okoki-1 by tie-lines.

5. The second seismic horizon ("Intra-Top-Set") was chosen as the nearest continuous reflector to the Castlecliffian-early Nukumaruan boundary at the Arawa-1 well location. The reflector was traced and picked across the study area, starting at Arawa-1. Well-tie correlations were made from the chosen reflector at Arawa-1 to Taimana-1 along a direct arbitrary tie-line and then a second arbitrary line tying directly to Witiora-1. The horizon was extended south and east around the southern termination of the Parihaka Fault and across the downthrown block. This reflector was picked on $250 \times 250$ inline/crossline spacing.

6. Faults offsetting the Intra-Top-Set horizon by greater than $\sim 25 \mathrm{~ms}$ were picked and assigned fault names ranging from Alpha to Zulu, following the phonetic alphabet convention. A total of 26 major faults were selected in the study area. Fault intersections were quality checked by picking on both crosslines and inlines, using the intersections of the fault surface to ensure a consistent fault pick in three dimensions.

7. The third seismic reflector (named "Basal Top-Set") was selected on the basis of being the lowermost continuous horizon within the top-set sequence at the Arawa-1 well location. Well-tie correlations were made from the chosen reflector at Arawa-1 to Taimana-1 along a direct arbitrary tie-line and then a second arbitrary line tying directly to Witiora-1. The horizon was then extended east around the southern termination of the Parihaka Fault and across the downthrown block. This reflector was first picked on a $250 \times 250$ inline/crossline spacing, then infilled on $50 \times 50$ inline/crossline spacing.

8. A fourth seismic reflector (named "Basal Foresets") was selected on the basis of being the uppermost continuous horizon bounding the base of the progradational and degradational foresetting package at the Arawa-1 well location. Well-tie 
correlations were made from the chosen reflector at Arawa-1 to Taimana- 1 along a direct arbitrary tie-line and then a second arbitrary line tying directly to Witiora-1. The horizon was then extended east around the southern termination of the Parihaka Fault and across the downthrown block. This reflector was first picked on a $250 \times 250$ inline/crossline spacing, then infilled on $50 \times 50$ inline/crossline spacing.

9. The validity of the lower three horizons were tested by connecting a loop-tie around two southern segments of the Parihaka Fault (Fig. 2.4c). The horizon was traced up a relay ramp structure separating en-echelon segments of the Parihaka Fault. A connecting loop was established, confirming that the seismic horizons were continuous across the survey area.

10. Fault polygons were selected on the base map, covering each individual fault segment. These polygons traced the areal extent of each fault segment in map view, and are utilised in the gridding process.

11. First pass grid maps were created as an initial quality check for seismic horizon misties and mis-interpretation indicators. Preliminary grids were evaluated for geological reasonability and picks were altered if deemed necessary. This step was re-iterated until the grid was deemed geologically sensible and most closely matched the seismic horizon seed-lines. Several more iterations were created in which settings were "fine-tuned" to produce the closest match to the seed line horizon. Final parameters are shown in appendix figure C.8.

12. Grid maps were converted from the time domain to the depth domain using a bestfit time-depth relationship derived from nearby offset well velocity data. Details of this process are included later in this chapter.

13. Isochore maps were generated by subtracting shallow depth grids from deeper depth grids. Two finalised isochore maps were produced, between the intra-top-set and basal top-set horizons (lower top-set sequence) and the basal top-set and basal foreset horizons (foreset sequence).

14. Seismic section images were generated from crosslines at regular crossline intervals within the Parihaka 3D. Two seismic section images were produced from each crossline: a seismic section annotated with horizons and faults and a seismic section flattened on the Intra-Top-Set horizon annotated with horizons, faults and channels. 
15. The Intra-Top-Set, Basal Top-Set and Basal Foreset horizons were extended from the Parihaka 3D survey to the ES89-120 2D seismic line. ES89-120 partially overlaps with the eastern edge of the Parihaka 3D making correlation of reflectors possible.

16. The seismic horizon was extended from ES89-120 to the orthogonal ES89 2D lines (ES89-118, -116, -114) that sit within the main depocentre east of the Parihaka Fault.

17. Seismic section images were generated from the ES89 2D lines that perpendicularly cut mega-channel 3 east of the Parihaka 3D seismic survey (ES89-118, -116, -114). Two seismic section images were produced from each 2D line: a seismic section annotated with horizons and faults and a seismic section flattened on the Intra-TopSet horizon annotated with horizons, faults and channels.

\section{Seismic Section Imaging}

Each seismic section was produced with the intent of illustrating a clear cross-section of the three largest northern mega-channels and, where present, the Southern Intrusive Complex to the SE. The lowest three horizons were included in these figures to show the variable thickening of the sedimentary section across the faults and over the volcanic intrusion.

Each imaged crossline was imaged twice, once as a regular seismic section and once as a seismic section flattened on the intra-top-set horizon. The first iteration illustrates the sedimentary section as it exists at the present day. The second iteration is intended as a demonstration of how the sedimentary section appeared at the time of deposition of the green horizon (Nukumaruan aged).

Seismic sections were produced on crosslines from crossline 3500 to 5250 at regular 250 crossline intervals. Horizons were displayed on an absolute horizontal scale of 1:65000 and vertical scale of 15 centimetres per second.

Seismic sections generated from selected lines of the ES89 2D seismic survey were also produced. Based on the location of the mega-channels within the Parihaka 3D, it was possible to estimate the direction in which the channels ran beyond the extent of the survey. Lines from the ES89 survey were chosen on the criteria that they intersected the mega-channels perpendicular to the direction of channelling. The mega-channels were traced from the SW to the NE as they evolved with increasing distance from source. 


\section{Coherency Cube Slices}

Coherency cube time-slices were created at regular intervals on the coherency volume by flattening on the basal foresets horizon. The slices are intended to demonstrate the morphological character of the three mega-channels and their distributary systems with increasing depth below the upper channel surface.

The coherency data was flattened on the gridded basal top-set horizon and sliced at $25 \mathrm{~ms}$ intervals from $50 \mathrm{~ms}$ above the basal top-set horizon to $250 \mathrm{~ms}$ below the basal top-set horizon.

\section{Horizon to Grid Conversion}

Each horizon was gridded using the gridding function of the $2 d / 3 d P a k$ of the Kingdom software package. A "Flex Gridding" algorithm was employed to create the closest possible match between the picked reflector and the continuous grid by using the horizon seed-lines as input. The fault polygons created during step 10 of the seismic interpretation process allowed the grids to terminate at the intersection with major (>25 ms offset) faults.

An initial first-pass grid was created using the default settings provided by Kingdom. "Bullseyes" and other geologically unreasonable features were investigated and remedied if they were found to be the result of a mis-tie between seed lines. Because the interpretation was made on 3D data, which is internally consistent, these issues were uncommon.

Once the first-pass grids were checked and verified to be correct, settings such as the data fit, smoothness and grid cell size were altered in small increments to find the closest possible fit between the grid and the reflector that was being simulated. The final settings used during gridding are shown in appendix figure C.8.

By observing the closeness of the fit between the grid and the reflector at an inline/crossline situated directly between two seed lines, the quality of the grid could be evaluated. This is because theoretically, the greater the distance from the seed lines the more obviously mismatched the gridding should become, while the fit between the grid and horizon pick should always be near-perfect on inlines/crosslines containing a seed-line. 


\section{Time to Depth Grid Conversion}

Grid maps in the time domain were converted to the depth domain using an assumed consistent time-depth structure spanning the majority of the Parihaka 3D survey, as observed at Taimana-1, Witiora-1 and Arawa-1 (Appendix fig. C.7). These wells demonstrate an excellent spatial consistency in the time-depth structure of the sedimentary section. When compared with the Albacore-1 time-depth curve to the $\mathrm{NE}$, it appears that the velocity structure remains consistent even within the Northern Taranaki Graben itself where the sedimentary section is deeper and younger.

The exception to this is the SE corner of the survey, beyond the southern intrusive complex, where the Okoki-1 time-depth curve demonstrates a significantly higher velocity structure in the sedimentary section than the other wells in the area.

A third-order polynomial curve was fitted to the Arawa-1 time-depth curve, which was assumed to be representative of the velocity structure of the study area. The "Extended Math" tool in Kingdom was used to convert the grids from a time value to a depth value by inputting each gridded time value as " $x$ " into the equation, with the depth calculated as " $y$ ".

\section{Isochore Calculation}

Isochores were calculated using the "Extended Math" tool in Kingdom. By doing a "Grid A minus Grid B" subtraction, taking the depth of the shallow grid and subtracting it from the depth of the deeper grid, a sediment interval thickness is obtained. These grids were subsequently contoured and published as isochore maps.

\section{Summary}

This chapter has outlined the steps undertaken during the process of interpreting the Pliocene section of the Parihaka 3D seismic survey. Seismic sections, coherency cube slices, depth grids and isochore maps were produced in an attempt to understand the response of sedimentation to normal faulting and investigate how these two factors have interacted through the Pliocene as each underwent a period of active deposition and extensional faulting. Each figure illustrates an aspect of the study area which fits into a larger geological picture. These figures are discussed and interpreted in the following chapters. 


\section{Results}

\section{$\underline{4.1 \text { Introduction }}$}

The results of the seismic interpretation and mapping study of the Pliocene-Recent Giant Foresets Formation are presented in this chapter. An emphasis is placed on imaging the large sediment transport features present in the study area and understanding the observed non-uniform sediment distribution. This is accomplished by imaging the Pliocene-Recent sedimentary section in the vertical and horizontal orientations through the use of a high quality 3D seismic volume and a post-processing coherency cube volume generated from the 3D seismic volume. Three 2D seismic lines were also studied in order to extend the study area to the NE, where a significant portion of the major depocentre is present.

Primary outputs are depth grid maps for key horizons, isochore maps of the intervals spanning key horizons, seismic sections oriented parallel and perpendicular to the major sediment transport features and coherency cube time-slices through key stratigraphic levels.

\subsection{Selected Horizons}

\section{Seafloor Horizon}

The seafloor horizon is a strong, coherent reflector across the entire study area (Fig. 4.1a). Water depths are shelfal and vary between $\sim 50-150 \mathrm{~m}$ in the study area. The shallowest water depths occur to the east and increase to the west, toward the modern day shelf break.

Biostratigraphic age: Not sampled.

Assigned absolute age: $0 \mathrm{Ma}$.

Seismic Character: A strong negative reflection event marks the seabed within the study area.

\section{Intra-Top-Set Horizon}

The Intra-Top-Set reflector sits within the top-set sequence of the Giant Foresets Formation, and is approximately intra-Nukumaruan in the study area (Fig. 4.1a). The reflector is moderately continuous; it merges and diverges with other reflectors across the study area 


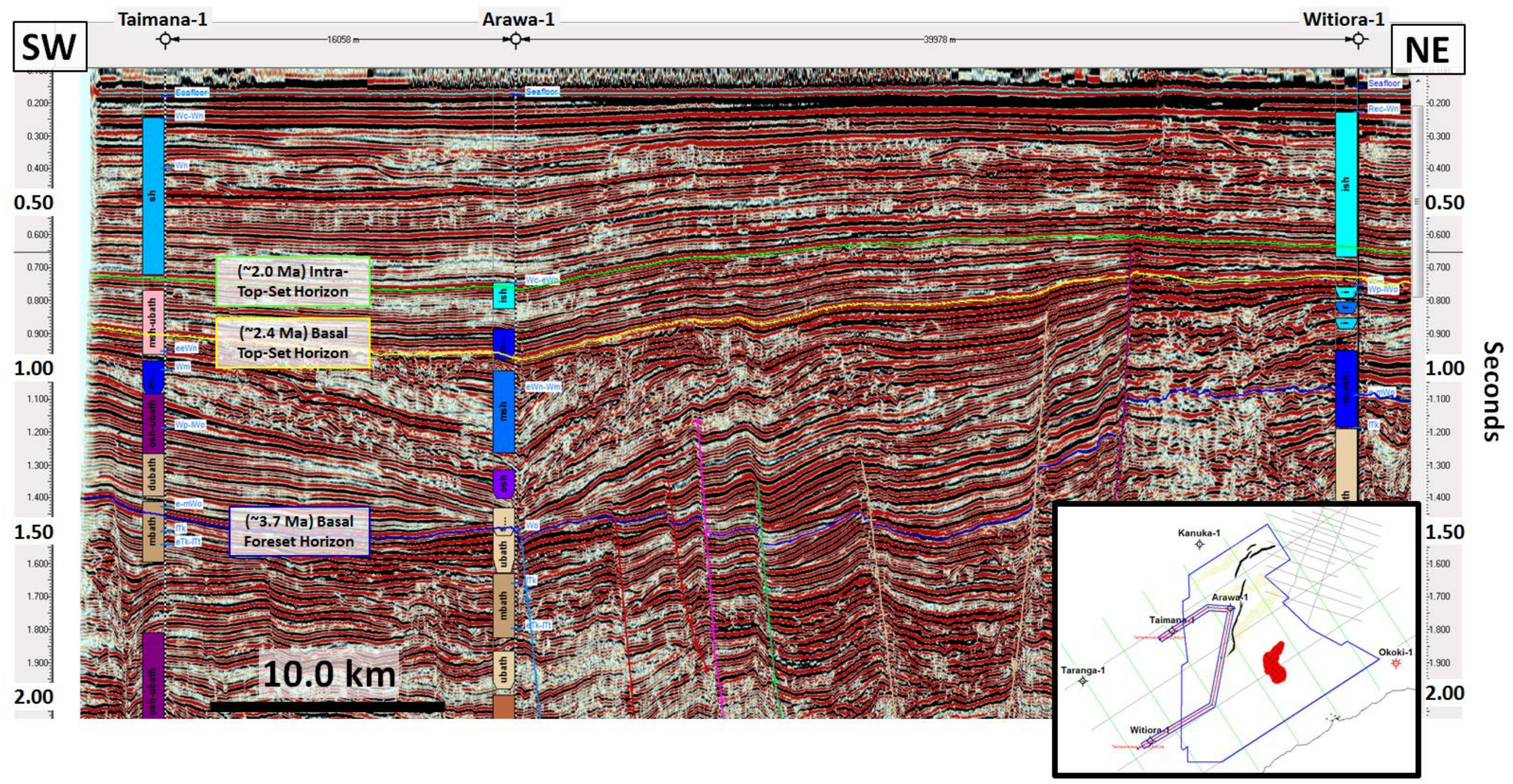

Figure 4.1a: Seismic section along an arbitrarily chosen path between Taimana-1, Arawa-1 and Witiora-1. Horizons are denoted by the cyan, green, yellow and blue lines. Well locations are denoted by the vertical dashed line beneath the symbol at the top of the figure. Paleoenvironmental determinations are displayed to the left of the well path as coloured squares. New Zealand stage determinations are displayed to the right of the well path as blue text on a white background. Seismic polarity convention is red for negative and black for positive. See appendix table D. 3 for full biostratigraphy results and the abbreviation descriptions. The position of the arbitrary seismic line is shown in the inset. 
where sediment thickness variations across faults. Numerous offlaps of the intra-top-set reflector are observed within the top-set sedimentary section, in particular on the downthrown side of normal faults within the study area.

Biostratigraphic age: Intra-Nukumaruan (Early Pleistocene)

Assigned absolute age: $\sim 2.0 \mathrm{Ma} \pm 0.4 \mathrm{Ma}$

Seismic Character (Upper Top-Set Sequence): This interval, spanning the seafloor horizon to the intra-top-set horizon, is dominated by low to high amplitude, moderately planar to curvi-planar reflectors arranged in a sheet to wedge geometry. Thickening of this interval across normal faults is indicated by numerous offlaps and thickening of reflection events in the direction of the hangingwall blocks. The upper half of the interval is hummocky, particularly in the main sediment transport direction. The lower half is strongly planar and conformable. Reflectors are internally parallel to sub-parallel throughout the interval. Semicontinuous to highly continuous reflection events trend towards moderate continuity in the primary direction of sediment transport. Amplitude strength is moderate to high throughout the interval.

\section{Basal Top-Set Horizon}

The basal top-set horizon sits near the base of the top-set sequence in the study area and is near basal Nukumaruan in age (Fig. 4.1a). The horizon follows a moderately continuous, moderate-high amplitude reflection event which is continuous across the majority of the study area. Loop ties have been established across the Parihaka Fault along relay zones separating fault segments within the Parihaka Fault which confirms that the reflection event is continuous within the study area.

Biostratigraphic age: Near base Nukumaruan (Early Pleistocene)

Assigned absolute age: $\sim 2.4 \mathrm{Ma} \pm 0.2 \mathrm{Ma}$

Seismic Character (Lower Top-Set Sequence): The seismic character of this interval, spanning the intra-top-set horizon to the basal top-set horizon, is consistent within the study area. The dominant seismic facies consists of parallel, continuous, high-amplitude reflection events. Reflectors are planar to curvi-planar in a sheet geometry. Offlaps are common where the interval thickens within primary depocentres and across normal faults. Minor channelling is evident in the lower portion of the interval oriented parallel to the primary sediment transport direction. 


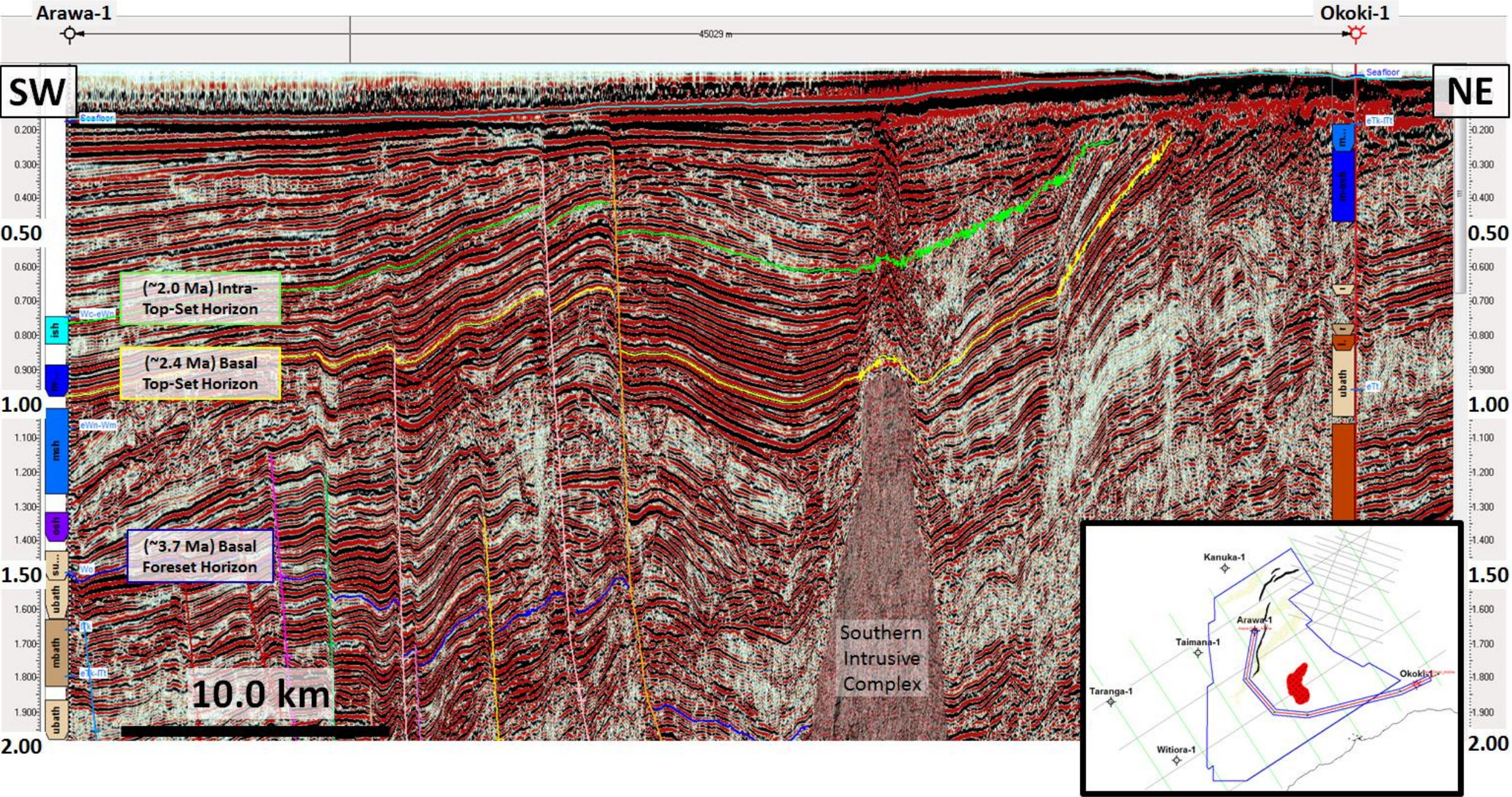

Figure 4.1b: Seismic section along an arbitrarily chosen path between Arawa-1 and Okoki-1. Horizons are denoted by the cyan, green, yellow and blue lines. Well locations are denoted by the vertical dashed line beneath the symbol at the top of the figure. Paleoenvironmental determinations are displayed to the left of the well path as coloured squares. New Zealand stage determinations are displayed to the right of the well path as blue text on a white background. Seismic polarity convention is red for negative and black for positive. See appendix table D.3 for full biostratigraphy results and the abbreviation descriptions. The position of the arbitrary seismic line is shown in the inset. 


\section{Basal Foresets Horizon}

The basal foresets horizon sits below the foresetting sequence within the study area and is approximately Opoitian/Waipipian boundary aged (Fig. 4.1a). The horizon follows the first coherent, obviously non-clinoformal reflector at the Arawa-1 location. However this reflection event is discontinuous and highly faulted, thus the horizon follows a loosely related series of reflection events that together form the ascribed base of the foresetting sequence.

Biostratigraphic age: Middle Opoitian (Early Pliocene)

Assigned absolute age: $3.7 \mathrm{Ma} \pm 0.8 \mathrm{Ma}$

Seismic Character (Foreset Sequence): The seismic character of this interval, spanning the basal top-set horizon to the basal foreset horizon, is varied with areas of strongly coherent, high amplitude, parallel dipping reflection events (progradational foresets) grading into chaotic, variable amplitude, lens to channel shaped reflections (degradational foresets). The degradational foreset sequence varies between weak to strong amplitudes which are heavily channel cut throughout.

\subsection{Well Correlation}

An arbitrary seismic line was chosen, starting at Taimana-1, stretching NE to Arawa-1 then curving clockwise to the SW to reach Witiora-1 (Fig. 4.1a). This created a tie-line between the three wells with a similar Late Miocene-Recent geological history. The seafloor, intratop-set and basal top-set reflectors were tied along a single reflector. The basal foreset reflector is continuous between Taimana-1 and Arawa-1 but entered a variable, disrupted seismic facies to the SW near Witiora-1. Within the disrupted seismic facies, the horizon was traced along a relatively flat-lying set of reflectors which paralleled the semi-continuous overlying and underlying reflectors.

A second arbitrary line tying Arawa-1 and Okoki-1 was chosen (Fig. 4.1b). This followed an identical trajectory as the third and fourth arbitrary points of the Taimana-Arawa-Witiora arbitrary line. The new line then deviated to the SE/E and out along the Okoki-1 swath line. Along this arbitrary line, the seafloor horizon followed a complete reflection event between the two wells. However the lower three horizons (intra-top-set, basal top-set, and basal foreset) were unable to follow a coherent reflector beyond the southern extent of the 


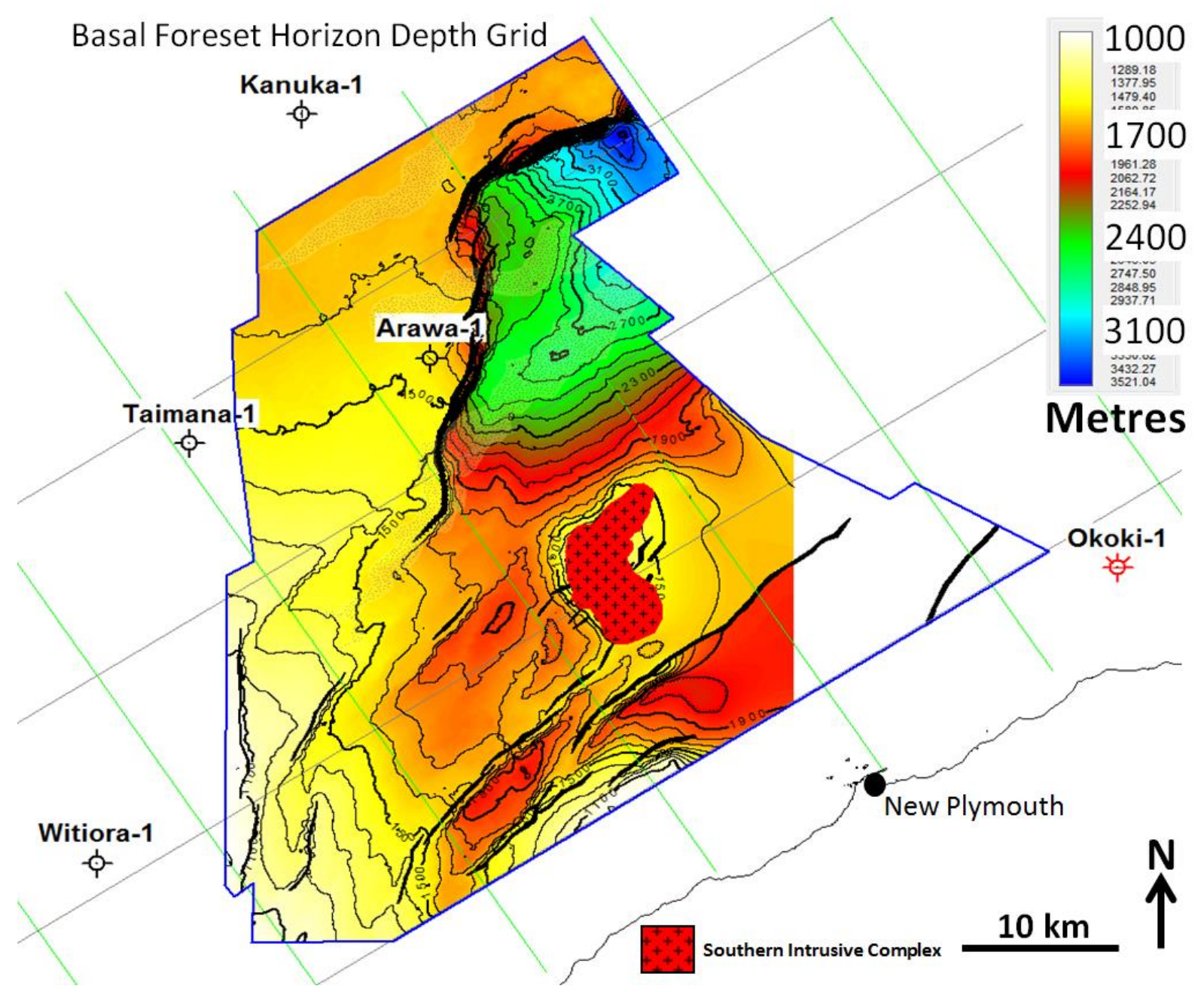

Figure 4.2a: Basal foreset horizon depth grid, illustrating the present day configuration of the base of the foresetting sequence within the Parihaka 3D seismic survey. Depths are in metres below sea level. Contours are evenly spaced at $\mathbf{1 0 0} \mathbf{m}$ intervals.

Southern Intrusive Complex. The intra-top-set and basal top-set horizons were traced to near the seabed where $\sim 1.5$ seconds of sedimentary section sub-crops beneath the uppermost 2-3 reflection events. The basal foreset horizon becomes untraceable once it reaches the intrusion.

Correlation of New Zealand stage intervals at each well was conformable and each horizon was age dated to within $\pm 0.8 \mathrm{Ma}$. The age of the three lower horizons was estimated by comparing the dated age of the reflection event at each well location and using the overlap in New Zealand stage intervals between each well to narrow down the approximate age to a smaller range of possibilities. 


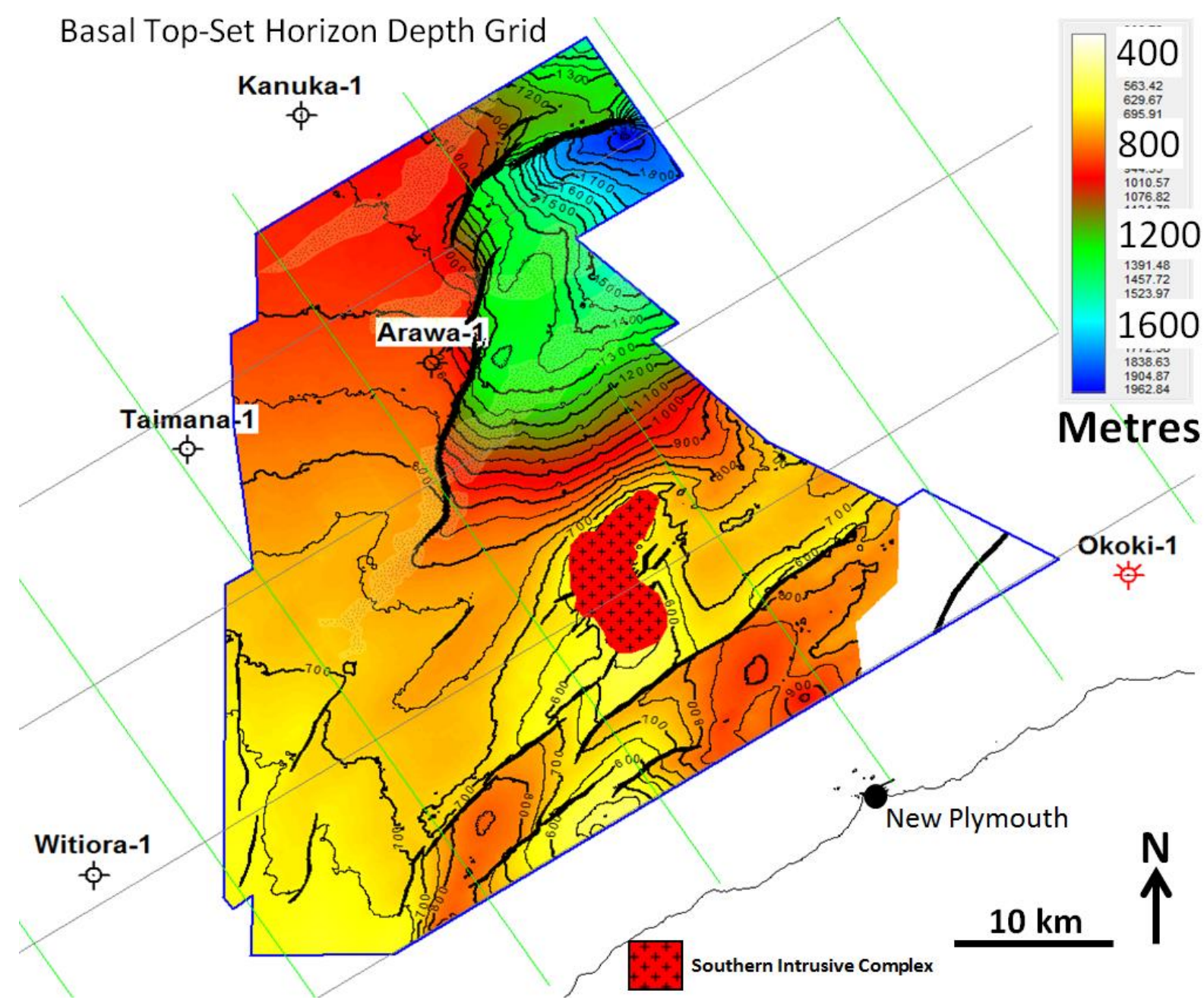

Figure 4.2b: Basal top-set horizon depth grid, illustrating the present day configuration of the base of the top-set sequence within the Parihaka 3D seismic survey. Depths are in metres below sea level. Contours are evenly spaced at $\mathbf{5 0} \mathbf{~ m}$ intervals.

\subsection{Depth Structure Maps}

Depth structure maps of the seafloor, intra-top-set, basal top-set and basal foreset horizons were generated from horizon picks made on reflectors within the Parihaka 3D and tied to the Arawa-1,

Taimana-1 and Witiora-1 wells. Depth structure maps demonstrate the geological and infilling history of the SW termination of the North Taranaki Graben by the GFF during the Plio-Pleistocene. The configuration of the three main seismic intervals (upper top-set, lower top-set and foresetting sequence) have been altered from their original depositional configuration by subsequent faulting and sedimentary compaction. The maps illustrate the magnitude of progressive normal faulting which has occurred since the Pliocene and 


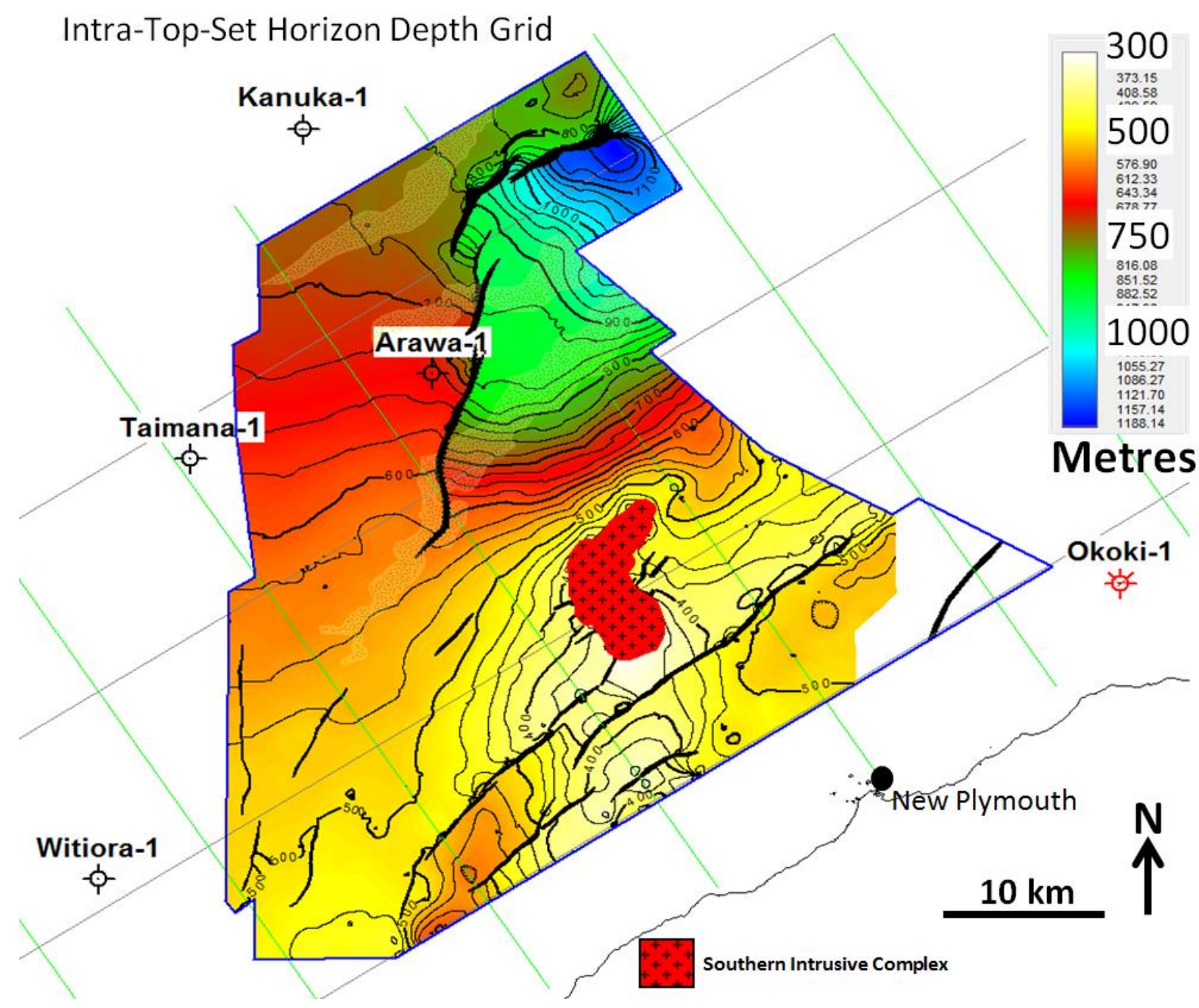

Figure 4.2c: Intra-top-set horizon depth grid, illustrating the present day configuration of a reflection event within the top-set sequence within the Parihaka 3D seismic survey. Depths are in metres below sea level. Contours are evenly spaced at $\mathbf{5 0} \mathrm{m}$ intervals.

continued during the Pleistocene. The depth structure maps are presented in order of decreasing depth.

\section{Basal Foreset Depth Grid}

The overall dip of this horizon within the survey is generally to the NNE (Fig. 4.2a). Most evident is the fault-bounded depression in the NE corner of the Parihaka survey, which sits $>1.5 \mathrm{~km}$ below the footwall block immediately to the NW. A gradual increase in fault offset along the Parihaka Fault is highlighted by an increase in faulting of the basal foreset reflector from SW-NE. An elongate depression trending SW-NE within the downthrown block is observed, corresponding with mega-channel 2. To the east of Parihaka Fault segments II/III, a structural bulge is visible. 
A second, narrow NE-oriented depocentre is observed in the south of the study area. This $>500 \mathrm{~m}$ deep, elongate depocentre is bounded by normal faults within the Turi Fault Zone.

Doming of the sedimentary section is observed flanking the large volcanic edifice, the Southern Intrusive Complex. The majority of the intrusion has penetrated the basal foreset reflector.

The grid has been clipped in the SE corner of the survey. The chaotic seismic facies in this area made tracing a coherent reflector impossible. Any pick through this area would have likely been diachronous and influenced by the interpreter's judgement.

\section{Basal Top-Set Depth Grid}

The basal top-set depth grid displays many of the same features as the basal foreset grid (Fig. 4.2b). The regional dip of this reflector is approximately NNE, with localised variations in dip direction proximal to major faults. The depocentre is still very evident in the NE of the study area, although the fault offset is smaller. Maximum observed offsets on the Parihaka Fault are $<500 \mathrm{~m}$. The structural bulge east of sections II/III is again visible in this grid. The elongate SW-NE depression that parallels mega-channel 2 is still present at this level also.

The basal top-set grid follows a strongly NE-dipping reflection event near the northern edge of the study area. This dipping reflection event corresponds to the location of paleo-shelf break at the time of deposition of the basal-top-set reflector.

The elongate depocentre in the SE of the survey is again visible at this stratigraphic level. The $\sim 250 \mathrm{~m}$ offset across the normal faults is approximately half the magnitude of the offset observed on the basal foreset grid.

Overlying the Southern Intrusive Complex, upward warping of the sedimentary section on a wavelength of $\sim 5 \mathrm{~km}$ is visible. The intrusion does not penetrate this reflector at any point.

The grid has again been clipped in the SE of the survey because the chaotic seismic facies makes it impossible to trace the basal top-set reflector within this area. 


\section{Intra-Top-Set Depth Grid}

The intra-top-set grid exhibits similar morphology to the previous grids (Fig. 4.2c). Regional dip is variable within this grid. The main dip-direction alternates between NW and NE. The Parihaka Fault appears to influence the dip-direction of the horizon up to $5 \mathrm{~km}$ from the fault-scarp.

The primary depocentre in the NE of the study area is still prominent in this grid, with a broad, N/NE-sloping footwall block. Offsets on the Parihaka Fault are $<300 \mathrm{~m}$ at this level. The structural bulge east of the Parihaka Fault and elongate depression within the hangingwall block are not present at this level. The shelf break has prograded beyond the bounds of the study area.

The elongate depocentre in the SE of the survey is much less evident at this stratigraphic level. The SW portion of the depocentre is still visibly active at this level but the depocentre appears to be verging on inactive to the NE. Offsets on the bounding faults are greatly reduced and only exceed $100 \mathrm{~m}$ in a few areas.

The reflection event still strongly dips away from the volcanic intrusion at this stratigraphic level, despite the top of the intrusion being well below this horizon. Doming of the sedimentary section at this level is clearly evident.

\subsection{Isochore Maps}

The difference in thickness between the intra-top-set and basal top-set horizon depth grids (lower top-set sequence, Fig. 4.3a) and the basal top-set and basal foreset horizon depth grids (foreset sequence, Fig. 4.3b) are illustrated in two isochore maps. The greatest increase in sediment thickness occurs within the large depocentre in the NE of the survey, where up to $2 \mathrm{~km}$ of fault offset is observed across the Parihaka Fault on the depth structure maps. The smallest sediment thickness increases occur around the Southern Intrusive Complex and in the SW of the survey within the footwall blocks of minor normal faults. 


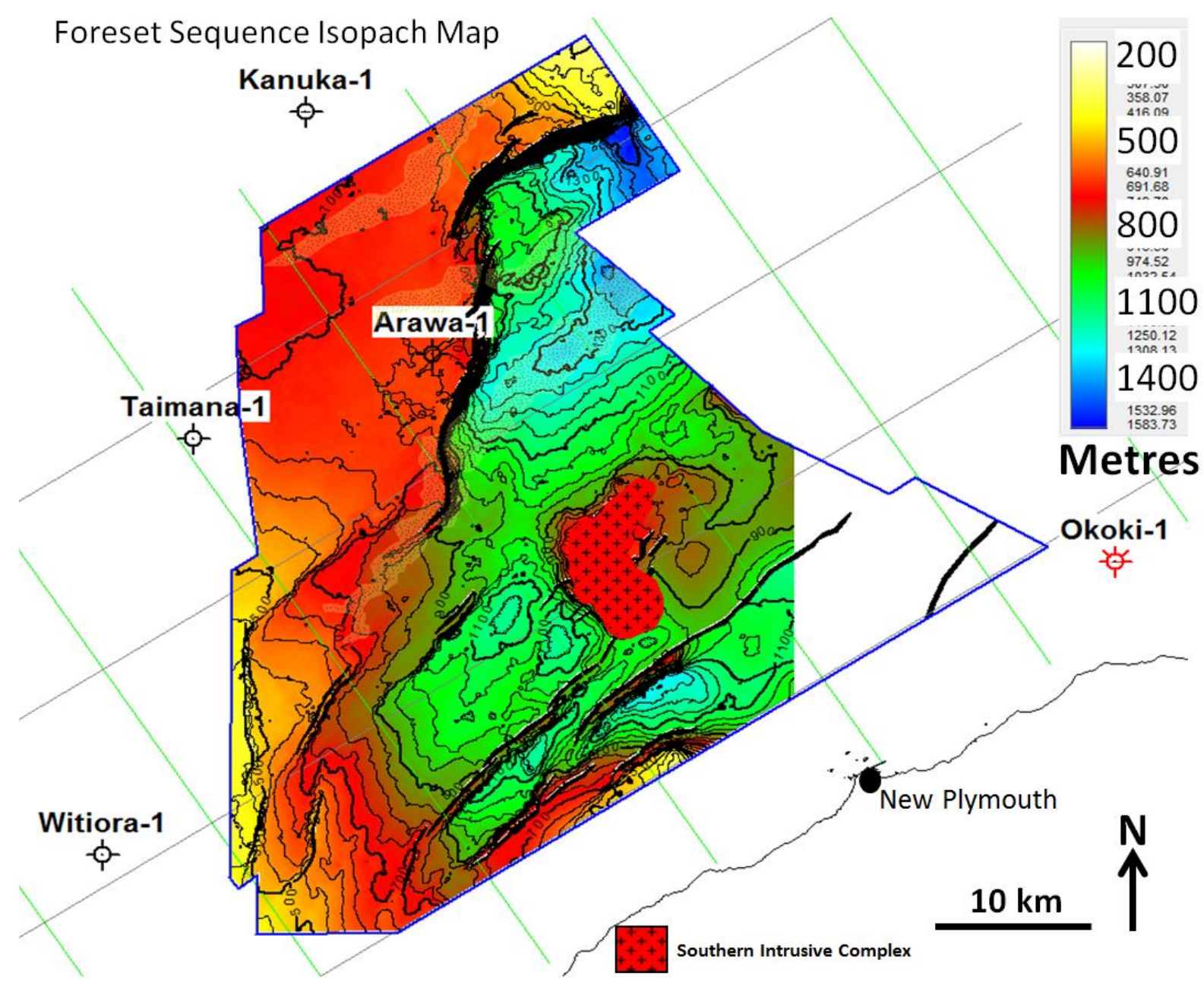

Figure 4.3a: Isochore map of the foreset sequence of the Giant Foresets Formation between the basal foreset and basal top-set depth grids within the Parihaka 3D seismic survey. Depths are in metres below sea level. Contours are evenly spaced at $\mathbf{5 0} \mathrm{m}$ intervals.

\section{Foreset Sequence Isochore Map}

Thickening of the sedimentary section over this interval is strongly asymmetrical across the study area (Fig. 4.3a). The sedimentary section within the footwall block to the west of the Parihaka Fault has increased in thickness by up to $800 \mathrm{~m}$. Sediment thickness increases of $>1500 \mathrm{~m}$ are observed within the primary depocentre to the NE.

Over this interval, the structural doming to the east of sections II/III of the Parihaka Fault is evident. A thinning of the sedimentary section is observed overlying this feature. Up to 200 $\mathrm{m}$ of sediment is missing relative to the surrounding depocentre. 


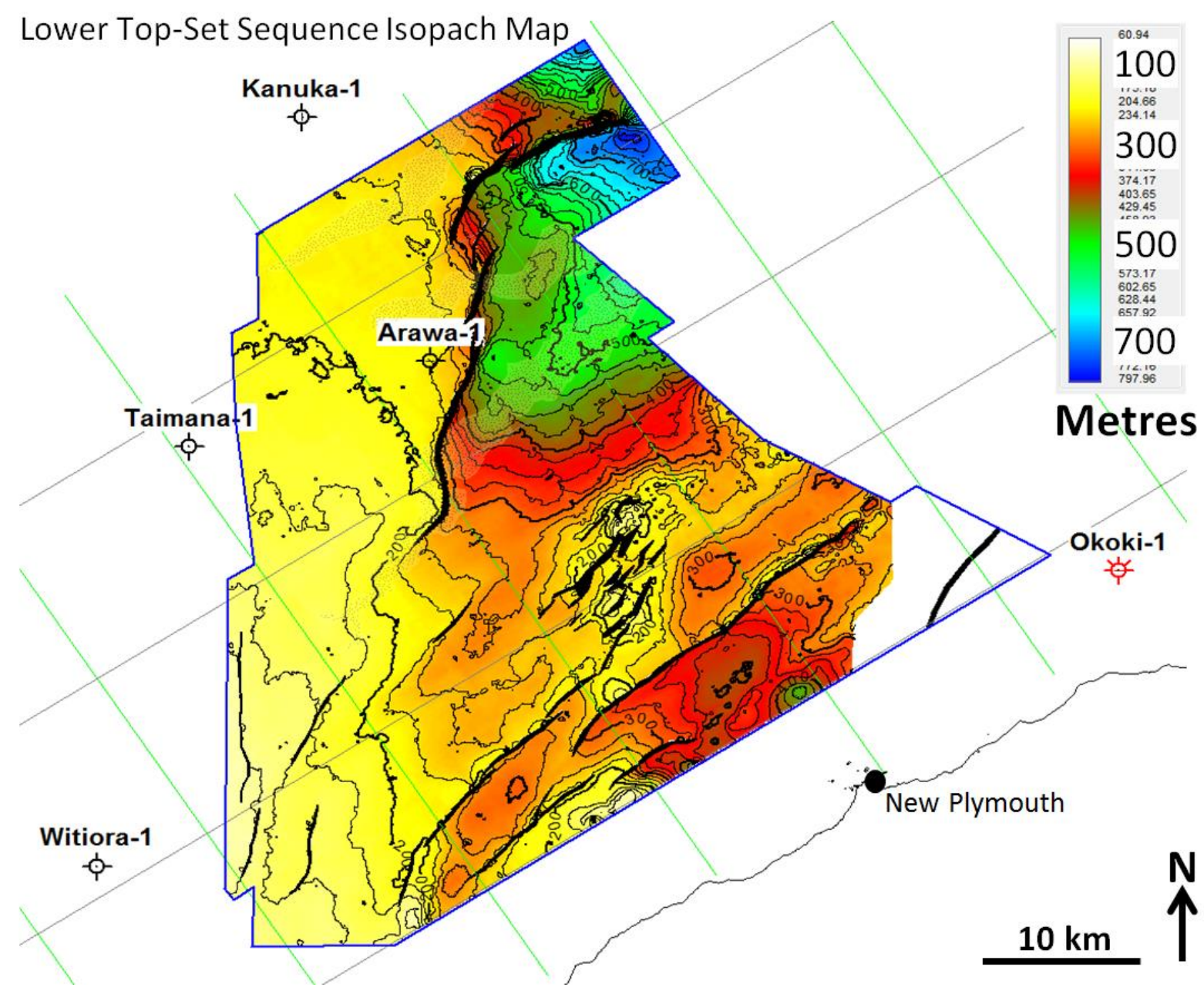

Figure 4.3b: Isochore map of the lower top-set sequence of the Giant Foresets Formation between the basal top-set and intra-top-set depth grids within the Parihaka 3D seismic survey. Depths are in metres below sea level. Contours are evenly spaced at $\mathbf{2 5} \mathrm{m}$ intervals.

The elongate SW-NE oriented depression that sits within the hangingwall block is also prominent in this isochore map. This feature contains up to $200 \mathrm{~m}$ of additional sediment thickness relative to the flanking areas.

The SW termination of the North Taranaki Graben is delineated by the transition from green to red in the figure colour scheme, marked by the bold $900 \mathrm{~m}$ contour. Sediment thickness increases of 200-500 m occur over short distances parallel to the SW-NE oriented normal faults, which bound the main depocentre and define the margins of Late Pliocene activity within the North Taranaki Graben.

The narrow, elongate depocentre in the south of the study area shows up to 1400 m of sediment thickness increase. This is up to $1000 \mathrm{~m}$ greater than the surrounding footwall blocks. The largest magnitude of thickening occurs proximal to the bounding normal faults. 


\section{Lower Top-Set Sequence Isochore Map}

This interval shows significantly less thickening than the underlying interval, particularly on the western side of the survey, however it still reaches a maximum of $\sim 800 \mathrm{~m}$ within the primary depocentre (Fig. 4.3b). Despite the magnitude of thickening of this interval being less than the previous interval, it is more rapid (1230 m/Ma vs. 2000 m/Ma). Sediment thickness increases are everywhere $<250 \mathrm{~m}$ on the western side of the Parihaka Fault. A similar pattern to the previous interval is observed, with the major sedimentary depocentres sitting within fault-bounded grabens.

The doming east of Parihaka Fault segments II/III is still evident in this isochore map, with an additional elongate depression on the SE margin of the structural bulge, closely corresponding to the position of mega-channel 2.

The interval sedimentary section notably thins over the Southern Intrusive Complex by up to $\sim 100 \mathrm{~m}$. This localised upward warping of the sedimentary interval is spatially limited to distances $<2 \mathrm{~km}$ from the intrusion. Minor depocentres to the SW and SE of the intrusion also highlight the irregular shape of the intrusive complex.

The elongate depocentre in the SE of the survey shows thickening of $\sim 300 \mathrm{~m}$ of relative to the surrounding footwalls.

\subsection{Coherency Slices}

The coherency cube volume was datumed on the basal top-set horizon and sliced at regular intervals of $25 \mathrm{~ms}$ from $50 \mathrm{~ms}$ above to $250 \mathrm{~ms}$ below the basal top-set horizon (Appendix figs. A.1a-m). The coherency data exhibits sharp images of fine- to large-scale channelling across the study area. There are three major NE-oriented channels in the study area which link with fine-scale ( $<50 \mathrm{~m}$-scale) meandering channels at their head. The minor channels are most clearly visible in the west of the survey within the footwall block of the Parihaka Fault, where they anastomose and coalesce to form large-scale ( $\mathrm{km}$-scale) mega-channels. A fourth large channel in the SE of the survey is oriented approximately east, originating from near the position of the Southern Intrusive Complex and feeding into the elongate ENEstriking graben. 


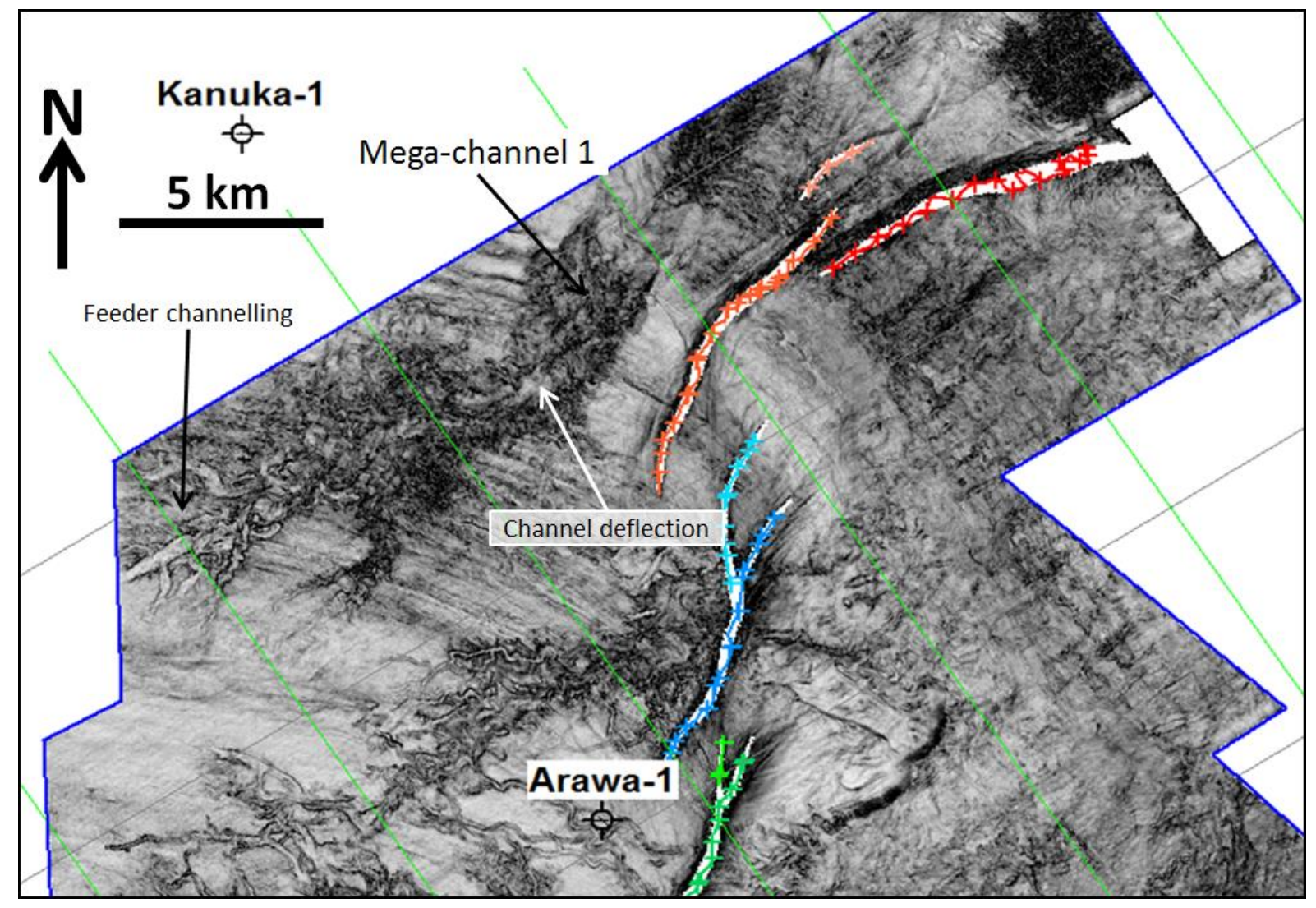

Figure 4.4a: A zoomed and annotated portion of the coherency slice $25 \mathrm{~ms}$ below the flattened basal top-set horizon (Appendix fig. A.1d) showing the location and main features of megachannel 1. Parihaka Fault segments are indicated by coloured lines with "+" symbols.

\section{Mega-Channel 1}

This ENE-oriented mega-channel is approximately $17 \mathrm{~km}$ long from the channel head to the point at which it leaves the northern edge of the study area (Fig. 4.4a). The channel reaches a maximum width of $\sim 2.5 \mathrm{~km}$ near the northern edge of the study area. Channel width steadily increases from the SW to the NE.

The main channel is oriented approximately ENE. There is one notable deflection in channel orientation near section III of the Parihaka Fault (Fig. 4.4a). The channel orientation curves from ENE to NNE, moving away from the Parihaka Fault. 


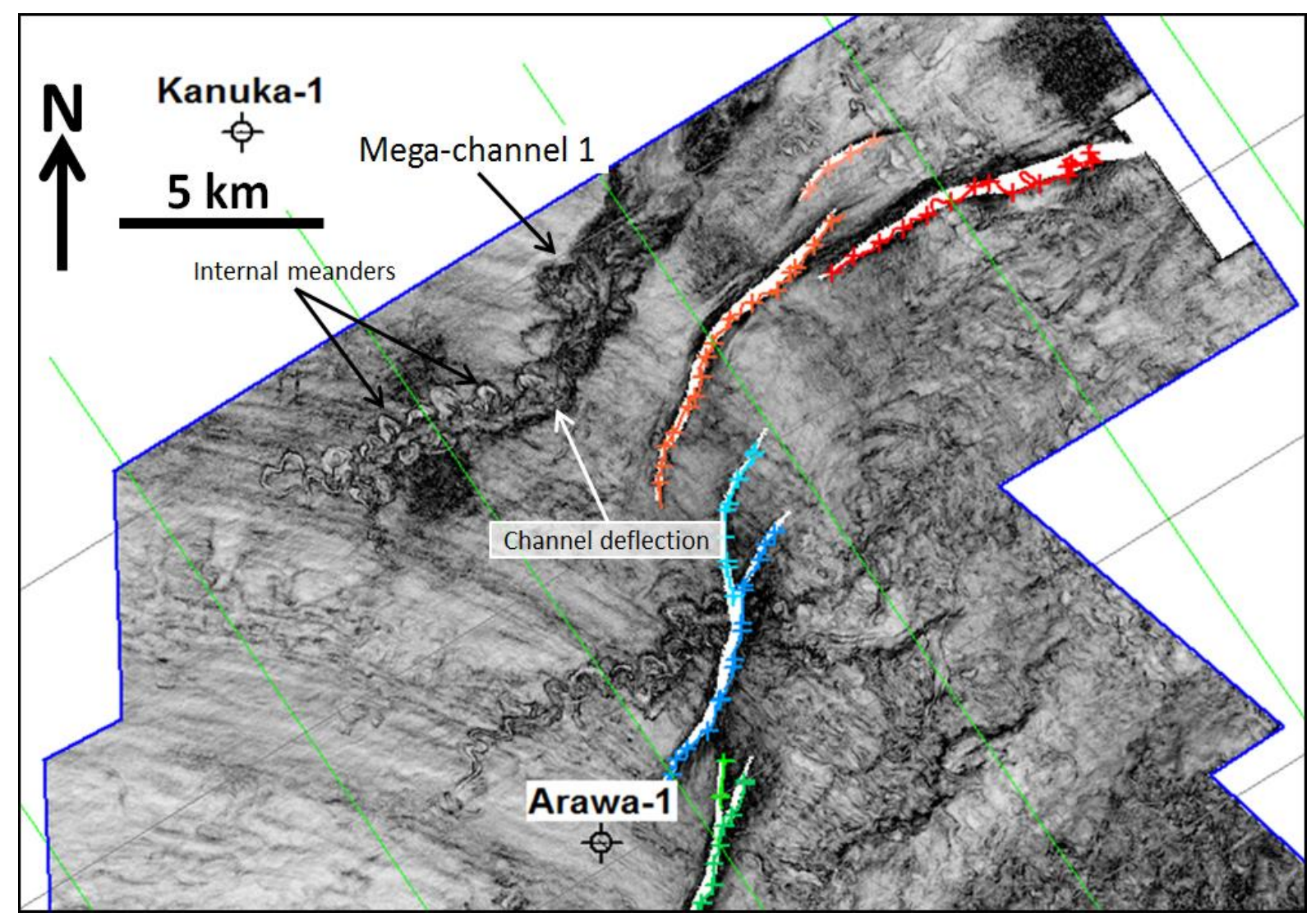

Figure 4.4b: A zoomed and annotated portion of the coherency slice $100 \mathrm{~ms}$ below the flattened basal top-set horizon (Appendix fig. A.1g) showing the location and main features of mega-channel 1. Parihaka Fault segments are indicated by coloured lines with "+" symbols.

The coherency slices illustrate that mega-channel 1 contained a meandering channel system within the lower third of the channel. The basal $50-100$ ms of the main channel contains 2-4 distinct internal channels anastomosing with one another (Fig. 4.4b). Numerous oxbows are visible throughout these meanders. Sinuosity of the internal channels (that is, the ratio between actual channel length and shortest path length) is estimated to range between 2 to 3 (Appendix fig. A.9). Channel sinuosity, the ratio between the channel's sinuous length and its straight line distance, is an indicator of the slope angle, discharge and sediment load (Hooke, 2007).

Mega-channel 1 does not have a large system of feeder channels. Figure 4.4a indicates some fine-scale channelling in the NW corner of the seismic survey at the head of the channel, however the extent, size and thickness of the feeder channels is far less than for those of mega-channels 2 and 3. 


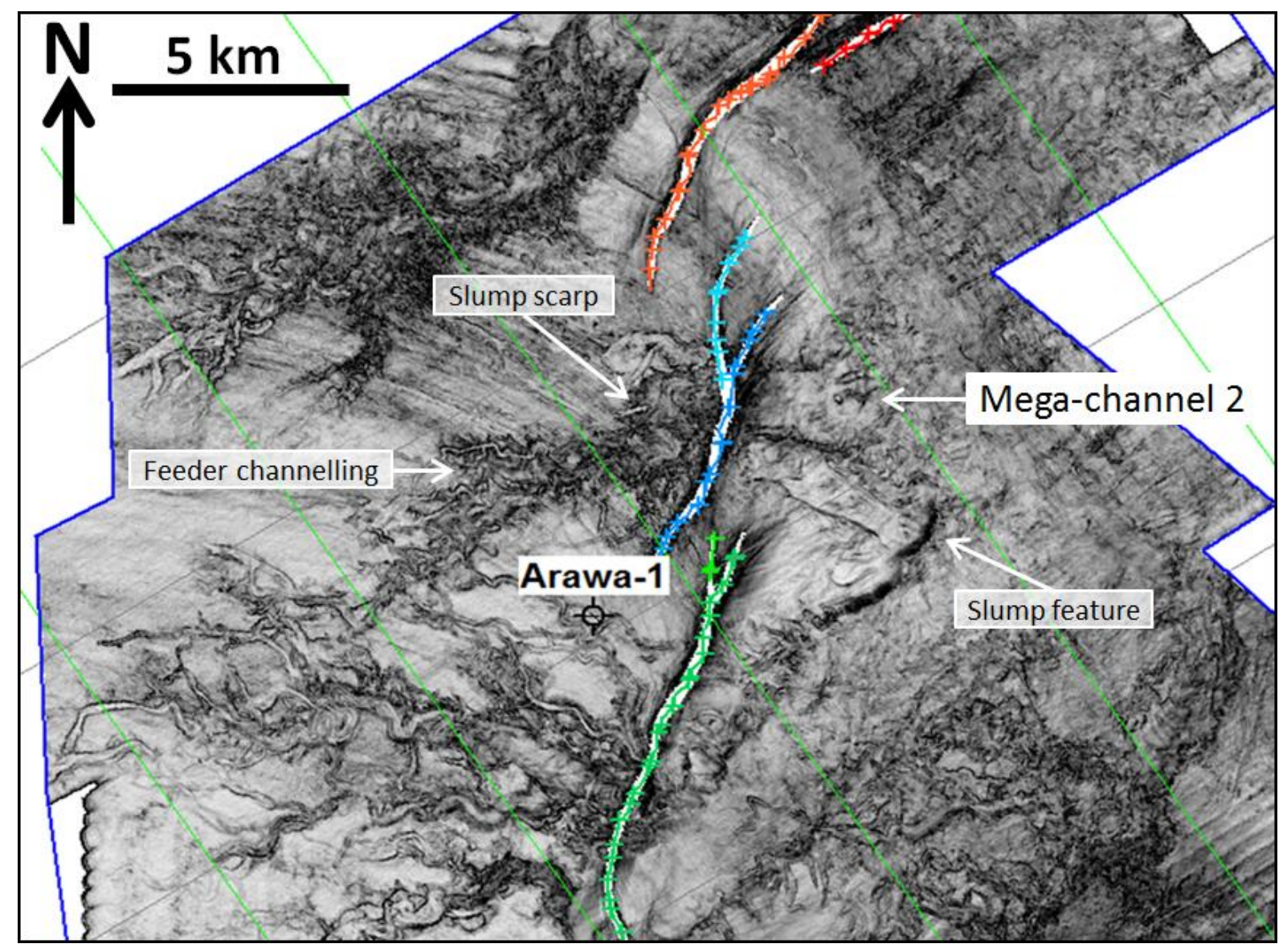

Figure 4.4c: A zoomed and annotated portion of the coherency slice $25 \mathrm{~ms}$ below the flattened basal top-set horizon (Appendix fig. A.1g) showing the location and main features of mega-channel 2. Parihaka Fault segments are indicated by coloured lines with " + " symbols.

\section{Mega-Channel 2}

Mega-Channel 2 is approximately $17 \mathrm{~km}$ long from the channel head NW of Arawa- 1 to the channel termination in the NE corner of the study area (Fig. 4.4c). Channel width increases from west to east, with a rapid increase east of the Parihaka Fault (Appendix figs. A.1e-h). Fine-scale ( $<100 \mathrm{~m}$ width) anastomosing feeder channels coalesce near the western side of Parihaka Fault segment II to form a mega-channel that spreads in width on the downthrown side of the Parihaka Fault (Fig. 4.4d). The mega-channel strongly slopes into the primary depocentre, with the upper channel surface quickly increasing in two-way time beneath the basal top-set reflector moving from west to east. Mega-channel 2 reaches a maximum width of $\sim 3 \mathrm{~km}$ before becoming impossible to trace visually within the coherency slices. Hints of a sedimentary fan system beyond the termination of the mega-channel are visible (Fig. 4.4d). 


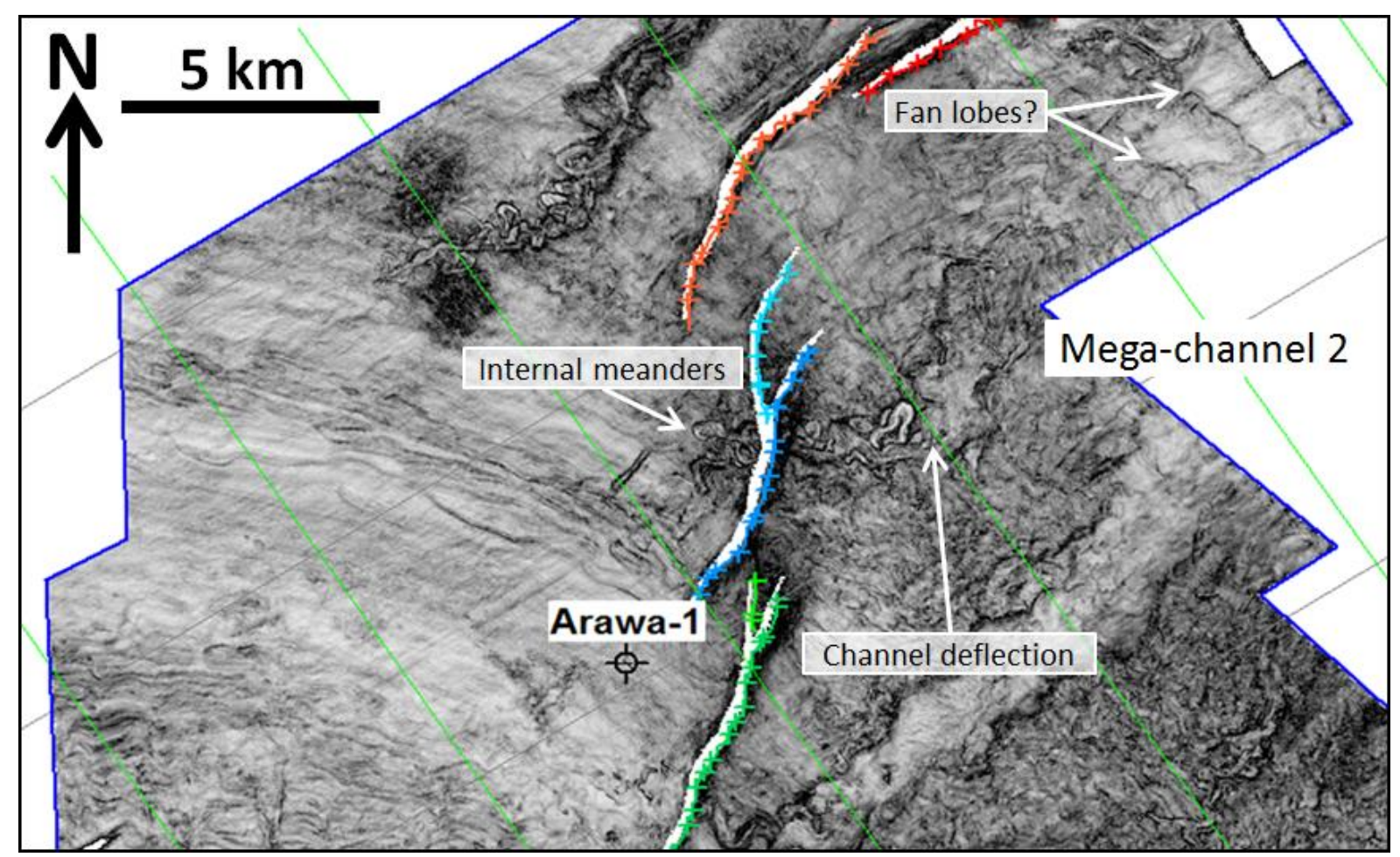

Figure 4.4d: A zoomed and annotated portion of the coherency slice $25 \mathrm{~ms}$ below the flattened basal top-set horizon (Appendix fig. A.1d) showing the location and main features of megachannel 2. Parihaka Fault segments are indicated by coloured lines with "+" symbols.

The channel is oriented approximately east however there are two notable deflections within the central portion of the visible channel (Appendix figs. A.1e-i). The first occurs as the channel crosses section II of the Parihaka Fault, rotating the channel orientation to the ESE, roughly perpendicular to the fault strike. The second deflection occurs east of the fault, where the channel orientation rotates to the NE, toward the primary depocentre within the study area (Fig. 4.4d).

Within the footwall block to the west of the Parihaka Fault, the mega-channel is flanked by multiple fine-scale feeder channels (Fig. 4.4c). Minor meandering channels are also visible within the basal 25 ms of the mega-channel (Fig. 4.4d; Appendix figs. A.1h-j). These finescale channels generally have an estimated sinuosity of $\leq 2$.

\section{Mega-Channel 3}

The southernmost mega-channel is the largest and most visually striking channel within the study area (Figs. 4.4e-f). Within the coherency time-slices, the mega-channel can be traced 


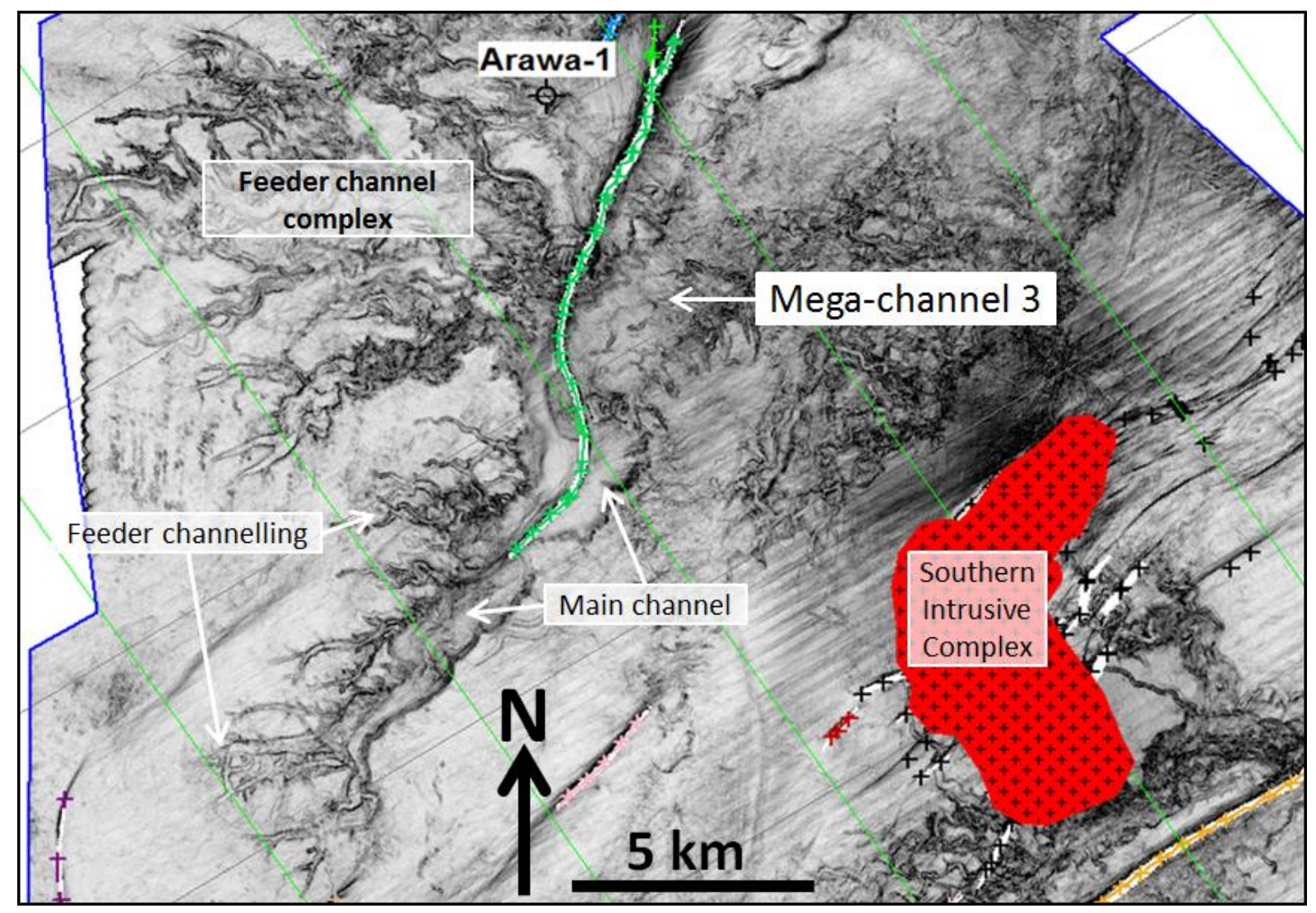

Figure 4.4e: A zoomed and annotated portion of the coherency slice $0 \mathrm{~ms}$ below the flattened basal top-set horizon (Appendix fig. A.1c) showing the location and main features of mega-channel 3. Segment I of the Parihaka Fault is indicated by the green coloured line with "+" symbols. The maximum extent of the Southern Intrusive Complex is highlighted by the red hatched polygon.

for approximately $30 \mathrm{~km}$ in length from the channel head SW of Arawa-1, to the eastern edge of the seismic volume (Appendix figs. A.1c-m). The channel width increases from a minor channel $(<100 \mathrm{~m})$ at its head to $4-5 \mathrm{~km}$ at the eastern edge of the Parihaka 3D seismic survey (Figs. 4.4e-f). The channel contains internal meandering channels within the basal 25-50 ms of the channel (Fig. 4.4f).

The main channel originates to the SW of the southern termination of segment I of the Parihaka Fault (Fig. 4.4e). Moving to the NE, the channel follows segment I of the Parihaka Fault for $\sim 6 \mathrm{~km}$ from its southern termination to a central portion of the fault segment where the fault strike curves to the NNW (Fig. 4.4e). The channel meanders across the main fault trace several times, with little or no obvious impediment from the fault. The megachannel then departs from the fault and moves in a NE direction into the hangingwall block. This section of the mega-channel is highly linear. 


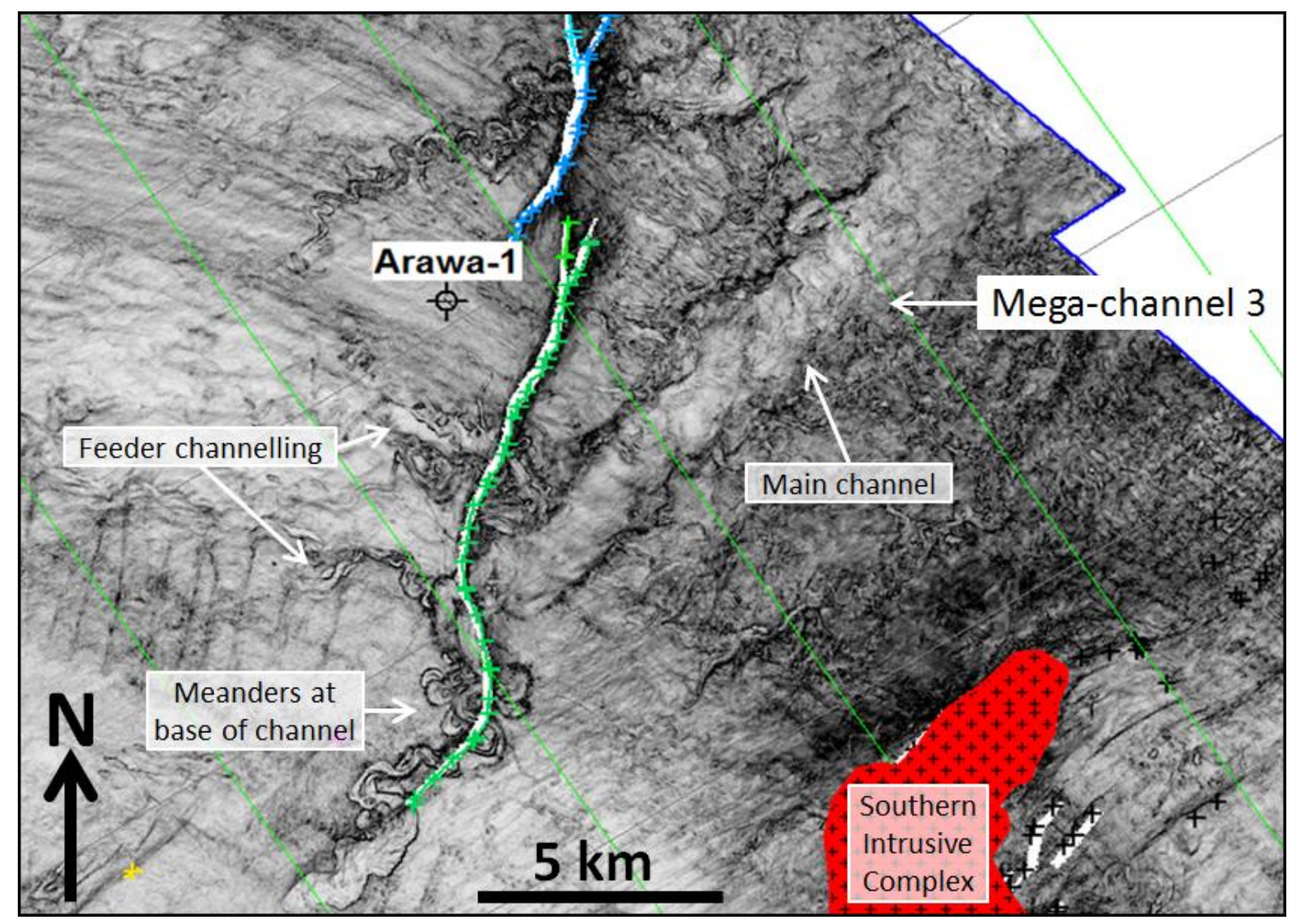

Figure 4.4f: A zoomed and annotated portion of the coherency slice $100 \mathrm{~ms}$ below the flattened basal top-set horizon (Appendix fig. A.1g) showing the location and main features of mega-channel 3. Segments I and II of the Parihaka Fault are indicated by the green and blue coloured lines with " + " symbols, respectively. The maximum extent of the Southern Intrusive Complex is highlighted by the red hatched polygon.

An aerially extensive complex $\left(\sim 80 \mathrm{~km}^{2}\right)$ of fine-scale feeder channels arranged in a dendritic pattern feed mega-channel 3 along the western channel margin, within the footwall block to the west of the Parihaka Fault (Fig. 4.4e). These feeder channels are oriented between approximately ENE to ESE and travel perpendicular to the fault strike. Some of these channels originate from outside the western margin of the seismic survey, to the NE of Taimana-1. Feeder channel width varies between 50 to $1000 \mathrm{~m}$.

The feeder channels have a low to moderate sinuosity, generally $<2$, while the internal meanders at the base of mega-channel 3 have a sinuosity of 2-3 (Figs. 4.4e-f).

\section{Primary Depocentre}


The level of coherence within the primary depocentre is high and visible sedimentary structures generally absent in the coherency slices. However between 2 and 4 concentric

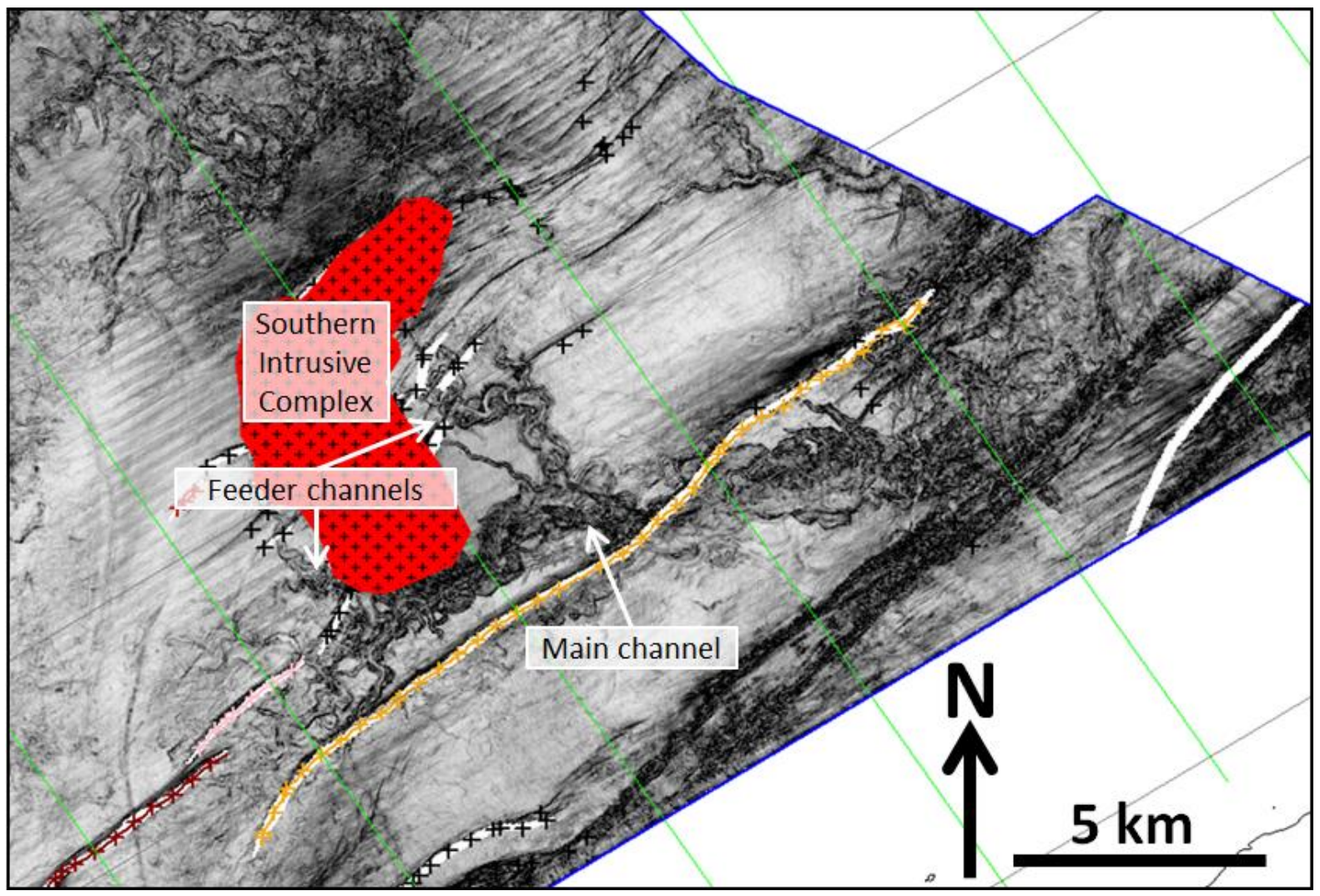

Figure 4.4g: A zoomed and annotated portion of the coherency slice $25 \mathrm{~ms}$ below the flattened basal top-set horizon (Appendix fig. A.1d) showing the location and main features of the large channel to the southeast of the Southern Intrusive Complex. Faults are indicated by coloured lines with "+" symbols. The maximum extent of the Southern Intrusive Complex is highlighted by the red hatched polygon.

semi-circles are present within the data just beyond the termination of mega-channel 2 (Fig. 4.4d). These appear to be the toe sets of sedimentary lobes or fans.

\section{Fault Scarp Slump Feature}

SE of segment II of the Parihaka Fault, a slump feature is visible in figure 4.4c. The feature appears to have travelled in a SE direction and a notable fan shape is visible where the slump ends. A semi-circular area of low coherency west of the fault, which indicates truncated/chaotic reflection events in the seismic data, appears to indicate a probable source of the slump. This is supported by the NW-SE orientation of a central channel that originates from the scarp. The position of the slump scarp corresponds with the location at which mega-channel 2 crosses the Parihaka Fault. 


\section{South-Eastern Channel}

A medium- to large-scale channel is observed in coherency slices SE of the Southern Intrusive Complex (Fig. 4.4g). The channel is composed of two feeder channels, which coalesce and cross the nearby SE-dipping, SW-NE striking normal fault. The two feeder channel sections appear to be deflected by the volcanic intrusion. This channel enters the elongate depocentre described in the sections 4.4 to 4.5 and travels NE beyond the survey margin.

\subsection{Seismic Sections}

Eight seismic cross-sections are oriented NW-SE, perpendicular to the primary sediment transport direction indicated by the three mega-channels observed within coherency slices (Appendix figs. B.1a-h). Two seismic cross-sections are included for each figure; the top cross-section shows the original seismic data without annotation, while the lower seismic cross-section has been flattened on the basal top-set horizon and the channels and volcanic intrusions highlighted. Appendix figures B.1a-h are evenly spaced at an interval of 250 crosslines, equal to $3.125 \mathrm{~km}$, between crossline $3500-5250$. This equates to a total distance of $21.875 \mathrm{~km}$ between appendix figures B.1a and B.1h. Supplementary zoomed and annotated seismic sections are presented in figures $4.5 \mathrm{a}-\mathrm{c}$.

In addition, mega-channel 3 has been traced beyond the eastern margin of the Parihaka 3D seismic survey using three 2D lines from the ES89 seismic survey (Figs. 4.5i-k). These three seismic sections run perpendicular to the channel orientation.

A further three seismic cross-sections are oriented along the axis of the three megachannels (Figs. 4.6a-c). Each has been selected as an "arbitrary line", with the seismic line position customised to run along the thalweg of each mega-channel. Two seismic crosssections are included for each figure; the top cross-section shows the original seismic data without annotation, while the lower seismic cross-section has been flattened on the basal top-set horizon, with the channel highlighted. 


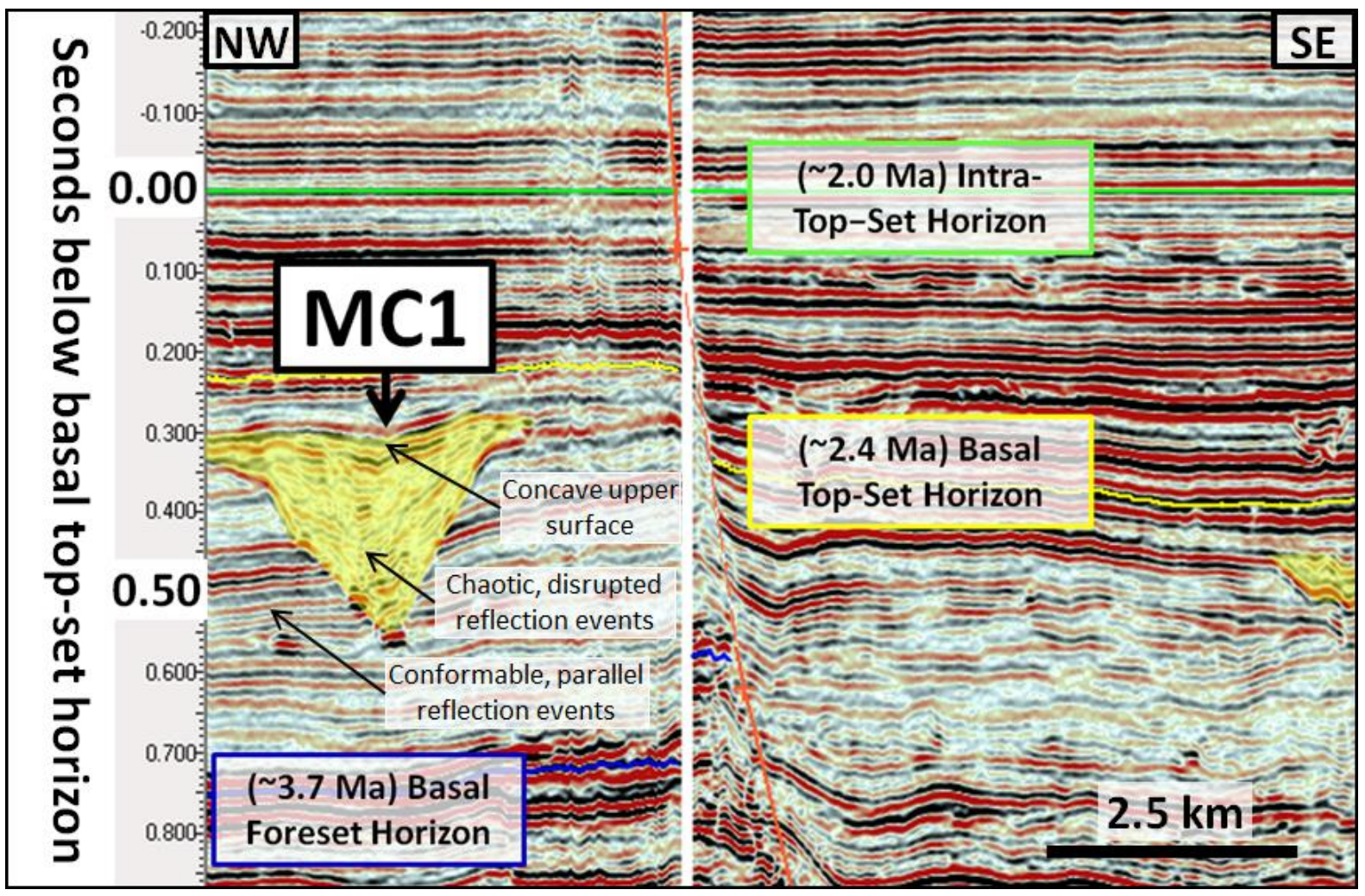

Figure 4.5a: Zoomed and annotated seismic section of crossline 5000 of the Parihaka 3D seismic survey flattened on the intra-top set horizon (Appendix fig. B.1g). The main features of megachannel 1 (MC1) in seismic cross-section are annotated. Mega-channels are highlighted by transparent yellow polygons. Horizons are labelled with coloured boxes. Faults are indicated by coloured lines with "+" symbols. Seismic polarity convention is red for negative and black for positive.

\section{Mega-Channel 1}

Mega-Channel 1 transitions from a broad, shallow anastomosing channel complex into a 3-4 $\mathrm{km}$ wide, 300+ ms thick mega-channel over a distance of $\sim 16 \mathrm{~km}$ (Appendix figs. B.1c-h). Parallel to the channel orientation and sediment transport direction mega-channel 3 exhibits a linear increase in thickness (Fig. 4.6a). Within the study area, the channel sits predominantly within the progradational foresetting sequence of the Giant Foresets Formation. The upper channel enters the degradational foresetting sequence near the edge of the study area (Appendix fig. B.1h).

In cross-section, the mega-channel is highlighted by a chaotic low to moderate amplitude seismic facies cutting into coherent, parallel and dipping, moderate amplitude seismic reflection events (Fig. 4.5a). The upper surface of the channel becomes increasingly concave upwards overlying the channel thalweg as the overall channel relief increases. 


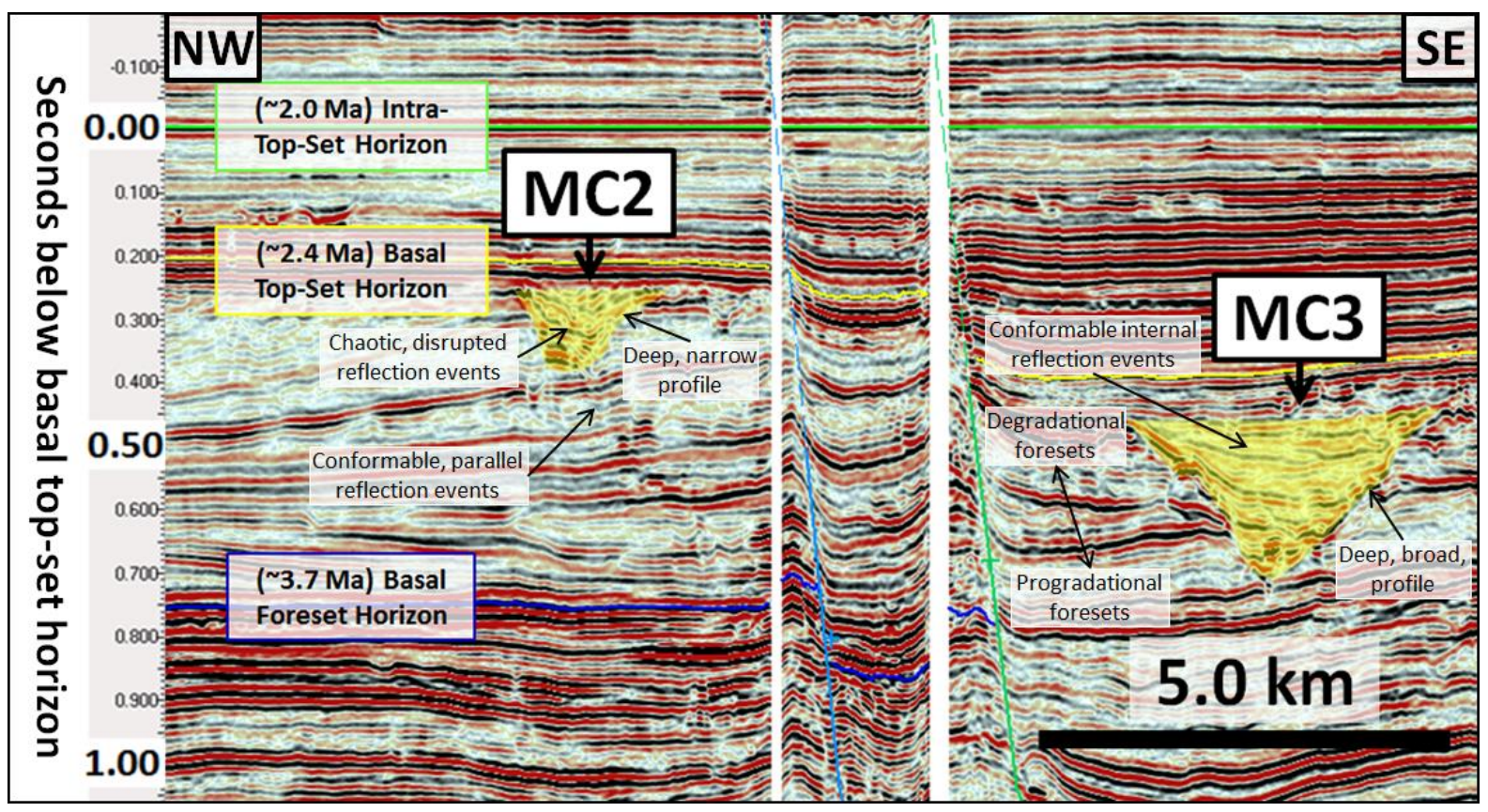

Figure 4.5b: Zoomed and annotated seismic section of crossline 4500 of the Parihaka 3D seismic survey flattened on the intra-top set horizon (Appendix fig. B.1e). The main features of megachannels 2 (MC2) and 3 (MC3) in seismic cross-section are annotated. Mega-channels are labelled and highlighted by transparent yellow polygons. Horizons are labelled with coloured boxes. Faults are indicated by coloured lines with " + " symbols. Seismic polarity convention is red for negative and black for positive.

\section{Mega-Channel 2}

Mega-channel 2 evolves from a broad, shallow series of sinuous fine-scale channels into a single narrow but deep channel (Fig. 4.5b), before returning to a more shallow and broad profile on the downthrown side of the Parihaka Fault, within the primary depocentre (Fig. 4.5c). Mega-channel 2 reaches a width of $\sim 4 \mathrm{~km}$ and relief of up to $200 \mathrm{~ms}$ two-way time within the footwall block west of the Parihaka Fault. The channel becomes narrower as it approaches the Parihaka Fault (Fig. 4.5b). After crossing the fault, the channel rapidly increases in width to $\sim 5 \mathrm{~km}$ and decreases in relief as it enters the primary depocentre (Fig. 4.5c). At the eastern margin of the seismic survey, the base of the channel is $200+$ ms below the basal top-set horizon, and only faintly visible in seismic cross-section (Appendix fig. B.1h).

Parallel to the channel, relief increases linearly within the footwall block of the Parihaka Fault before decreasing again in an approximately linear fashion on the downthrown side of the fault (Fig. 4.6b). Mega-channel 2 eventually merges with the surrounding reflection 


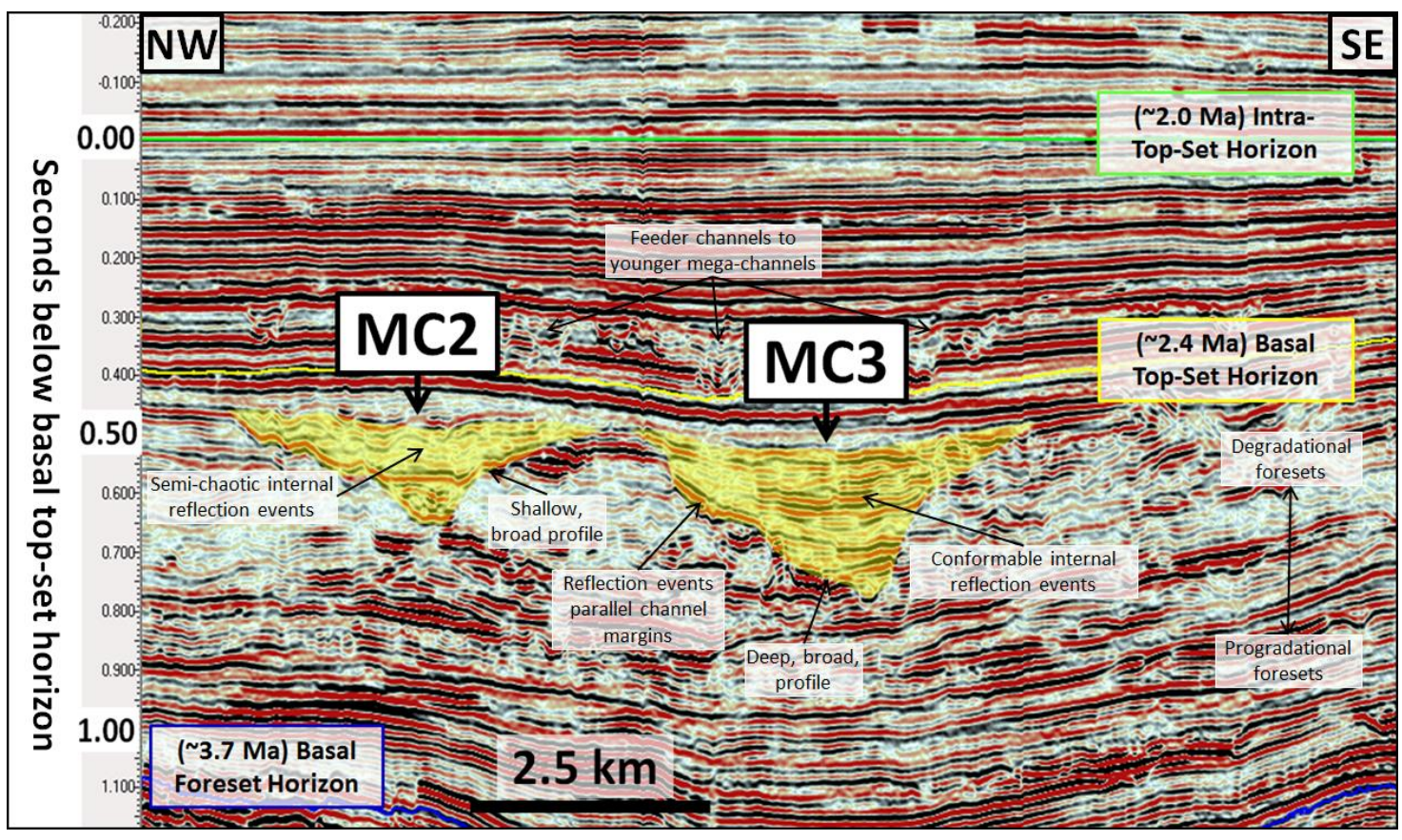

Figure 4.5c: Zoomed and annotated seismic section of crossline 5000 of the Parihaka 3D seismic survey flattened on the intra-top set horizon (Appendix fig. B.1g). The main features of megachannels 2 (MC2) and 3 (MC3) in seismic cross-section are annotated. Mega-channels are labelled and highlighted by transparent yellow polygons. Horizons are labelled with coloured boxes. Faults are indicated by coloured lines with " + " symbols. Seismic polarity convention is red for negative and black for positive.

events within the primary depocentre.

In cross-section, the seismic facies is dominantly chaotic and discontinuous, with low to moderate amplitude reflection events within a channel that is delineated by truncations of the surrounding low amplitude planar reflections. Parallel to the channel orientation, seismic facies is again predominantly chaotic and disrupted, with low to moderate amplitudes.

\section{Mega-Channel 3}

Mega-channel 3 is the largest of the three major channels within the foresetting sequence in the study area. The channel can be traced to the eastern margin of the Parihaka 3D seismic survey where it continues to the NE (Appendix figs. B.1a-h). Seismic lines from the ES89 2D seismic survey allow the channel to be further tracked to its ultimate extent within the primary depocentre (Appendix figs. B.1i-k). Only three seismic lines from the ES89 survey contain images of mega-channel 3 , however these help to determine the full extent and morphology of the channel. 


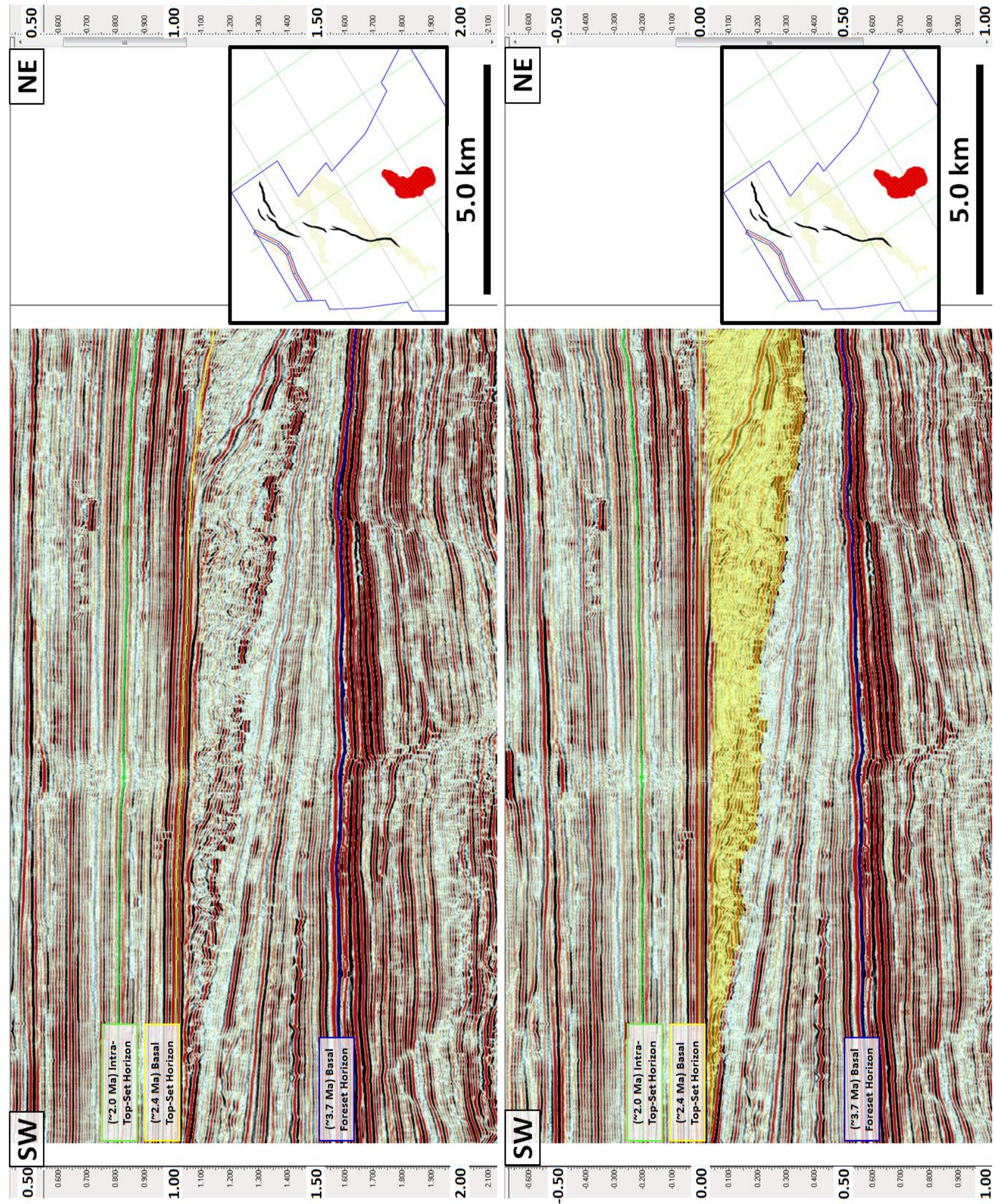

Figure 4.6(a): Arbitrary seismic sections oriented along the length of mega-channel 1 within the Parihaka 3D seismic survey. The upper panel illustrates the original seismic data along the arbitrary line. The lower panel is flattened on the basal top-set horizon. Mega-channel 1 is highlighted by a transparent yellow polygon. Horizons are labelled with coloured boxes. Seismic polarity convention is red for negative and black for positive. 
Moving to the NE, beyond the eastern margin of the Parihaka 3D, mega-channel 3 decreases rapidly in width and relief. Over 6-7 km, the channel merges with the surrounding reflectors until it is no longer visible. The relief of the channel below the basal top-set horizon also increases rapidly over this distance $(30 \mathrm{~ms} / \mathrm{km})$.

Mega-channel 3 is dominated by moderately planar, low to moderate amplitude reflection events. For the first visible half of mega-channel 3, up to the departure from the Parihaka Fault, channel margins are delineated by the truncation of the planar reflection events of the progradational foreset sequence (Appendix figs. B.1a-c). East of the fault the reflection events are gradually replaced by a discontinuous and chaotic seismic facies, marking the transition to the degradational foresets sequence. Here, the channel is delineated by an abrupt change from the chaotic degradational seismic facies to more coherent semi-parallel seismic reflectors internally (Appendix figs. B.1d-h). Channel margins are occasionally further delineated by reflection events that closely parallel the channel wall (Fig. 4.5c).

Along the length of mega-channel 3, in arbitrary seismic section, the relief of mega-channel 3 linearly increases up to a maximum of $\sim 300 \mathrm{~ms}$ (Fig. 4.6c). The seismic facies of the channel west of the Parihaka Fault mainly consists of discontinuous and hummocky reflections. East of the Parihaka Fault, the internal reflection events consist moderately coherent reflection events arranged in a foresetting pattern.

\section{Other Features of Interest}

Thinning of the sedimentary section over the Southern Intrusive Complex is evident in seismic cross section (Figs. 4.5f-g). While the thickness of the foresetting sequence remains constant overlying the intrusion, the thickness of the top set sequence shows a notable decrease directly overlying the peak of the intrusion. This is achieved by thinning and onlapping of reflector onto strata overlying the intrusion.

A series of moderate- to large-scale channels are observed to overlie the basal top-set horizon near the eastern margin of the study area. These appear to grow from minor, finescale channels into much larger channels comparable in size to the mega-channels 


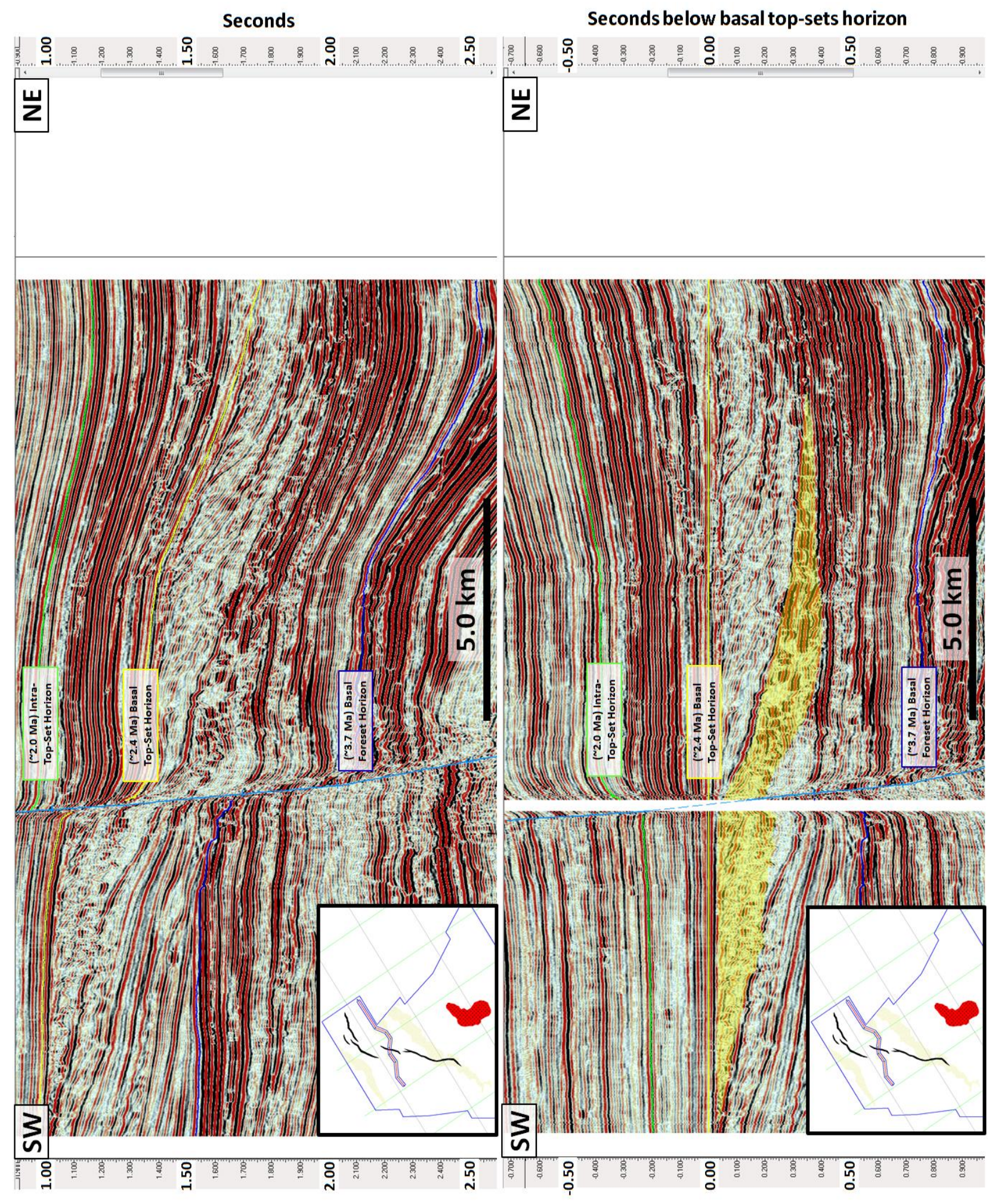

Figure 4.6b: Arbitrary seismic sections oriented along the length of mega-channel 2 within the Parihaka 3D seismic survey. The upper panel illustrates the original seismic data along the arbitrary line. The lower panel is flattened on the basal top-set horizon. Mega-channel $\mathbf{2}$ is highlighted by a transparent yellow polygon. Horizons are labelled with coloured boxes. Faults are indicated by coloured lines with "+ symbols. Seismic polarity convention is red for negative and black for positive. 
described in this study over a distance of $\sim 6.5 \mathrm{~km}$. They appear to be oriented parallel to the direction of sediment transport exhibited by mega-channels 2 and 3 .

\subsection{Summary}

This chapter has explored and documented the major features observed within Pliocene to Recent sedimentary section of the Parihaka 3D and ES89 2D seismic surveys. Primary outputs were depth grids and isochore maps, coherency cube slices from the postprocessing coherency cube dataset, and seismic sections from the Parihaka 3D and ES89 2D seismic surveys oriented parallel and perpendicular to the primary sediment transport direction.

Major SW-NE oriented channels up to $6 \mathrm{~km}$ wide and $350 \mathrm{~ms}$ two-way time in thickness are observed within the foresetting sequence crossing and being diverted by the Parihaka Fault and entering the primary depocentre in the NE of the survey. The mega-channel heads are positioned within the progradational foresetting sequence and span the transition to the degradational foresetting sequence, within the downthrown hangingwall block east of the Parihaka Fault.

The mega-channels are observed to contain a series of fine-scale sinuous feeder channels at the channel-head that coalesce into a km-scale mega-channel. In cross-section, the megachannels are narrow and shallow at their head, becoming increasingly wider and thicker with increasing distance along the channel. Where mega-channels 2 and 3 are traced to their down-dip termination, they are observed to decrease in width and decrease in thickness before finally merging with the surrounding sedimentary section.

The mega-channels contain a variable seismic character which appears to be correlated with the size and position of the channel, and the level of sinuosity of internal channel meanders. The channels contain a variable internal seismic character which alternates between low to moderate amplitude, discontinuous and chaotic seismic reflectors near the channel head and low to high amplitude, moderately continuous and moderately conformable seismic reflectors within the middle and later sections of the channels. 


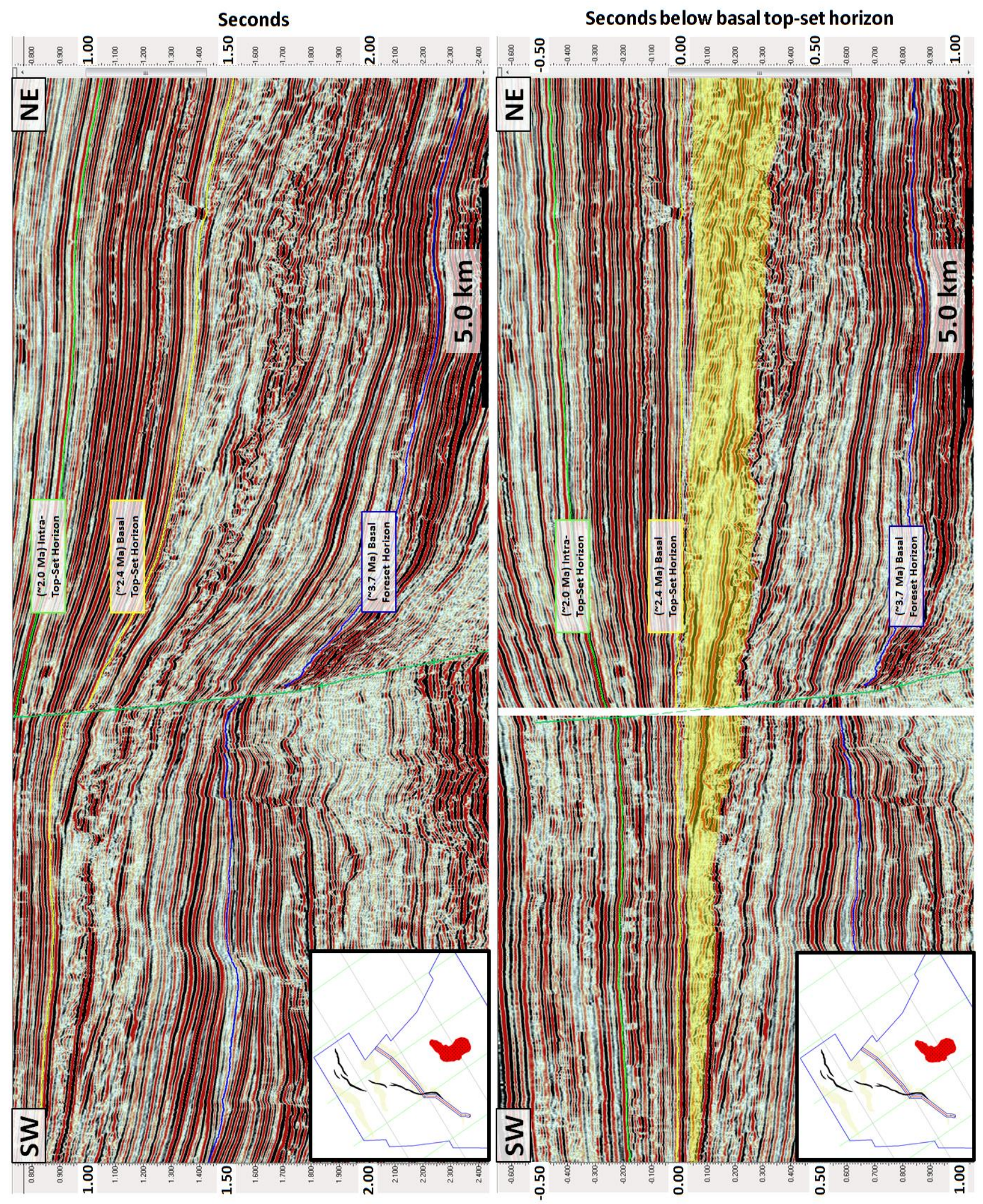

Figure 4.6c: Arbitrary seismic sections oriented along the length of mega-channel 3 within the Parihaka 3D seismic survey. The upper panel illustrates the original seismic data along the arbitrary line. The lower panel is flattened on the basal top-set horizon. Mega-channel 3 is highlighted by a transparent yellow polygon. Horizons are labelled with coloured boxes. Faults are indicated by coloured lines with "+ symbols. Seismic polarity convention is red for negative and black for positive. 


\section{Page intentionally left blank}




\section{Interpretation and Discussion}

\section{$\underline{5.1 \text { Introduction }}$}

Three NE-oriented channels with km scale width dimension are observed within the foresetting sequence of the Giant Foresets Formation in the study area. They have been termed mega-channels 1, 2 and 3 moving from north to south. We describe the role these channels have had in infilling depressions produced by extensional faulting within the Cape Egmont and Turi Fault Zones. Relevant to this discussion is the interaction of the channels with these fault zones and the multiple Miocene-Pliocene aged volcanic intrusions that are present within the study area. We also discuss the likely mechanisms by which these channels were formed, how they evolved, and their eventual infill and burial.

\subsection{Infilling of the Arawa Sub-Basin}

The previously unnamed Arawa Sub-Basin is a discreet sedimentary depocentre sitting to the east of the Arawa Ridge in the NE corner of the study area. The roughly circular subbasin is the largest Pliocene depocentre in the North Taranaki Graben. Unlike some other large sedimentary depocentres to the south (e.g. Toru Trough), the depocentre in the study area is a discreet sub-basin produced by upper-crustal faulting and subsidence. The structure is primarily fault-controlled with bounding volcanic intrusions which have enhanced the entrapment of large volumes of sediment. Normal faulting on the reactivated Parihaka Fault during the Pliocene-Recent produced up to $2 \mathrm{~km}$ of subsidence within the depocentre, generating accommodation space which was infilled by the prograding Giant Foresets Formation. Volcanic intrusions of the Late Miocene-Pliocene Mohakatino Formation formed boundaries on the eastern and southern margin of the depocentre, helping to funnel sediment into the depocentre and partially inhibiting the northward migration of sediment further into the North Taranaki Graben.

During the Early Pliocene prograding foresets of the Giant Foresets Formation were entering the Northern Taranaki Basin from the south. The dominant direction of progradation was to the NNW (Hansen, 2002). However localised faulting and intrusive volcanic activity was capable of temporarily redirecting and capturing sediment. 


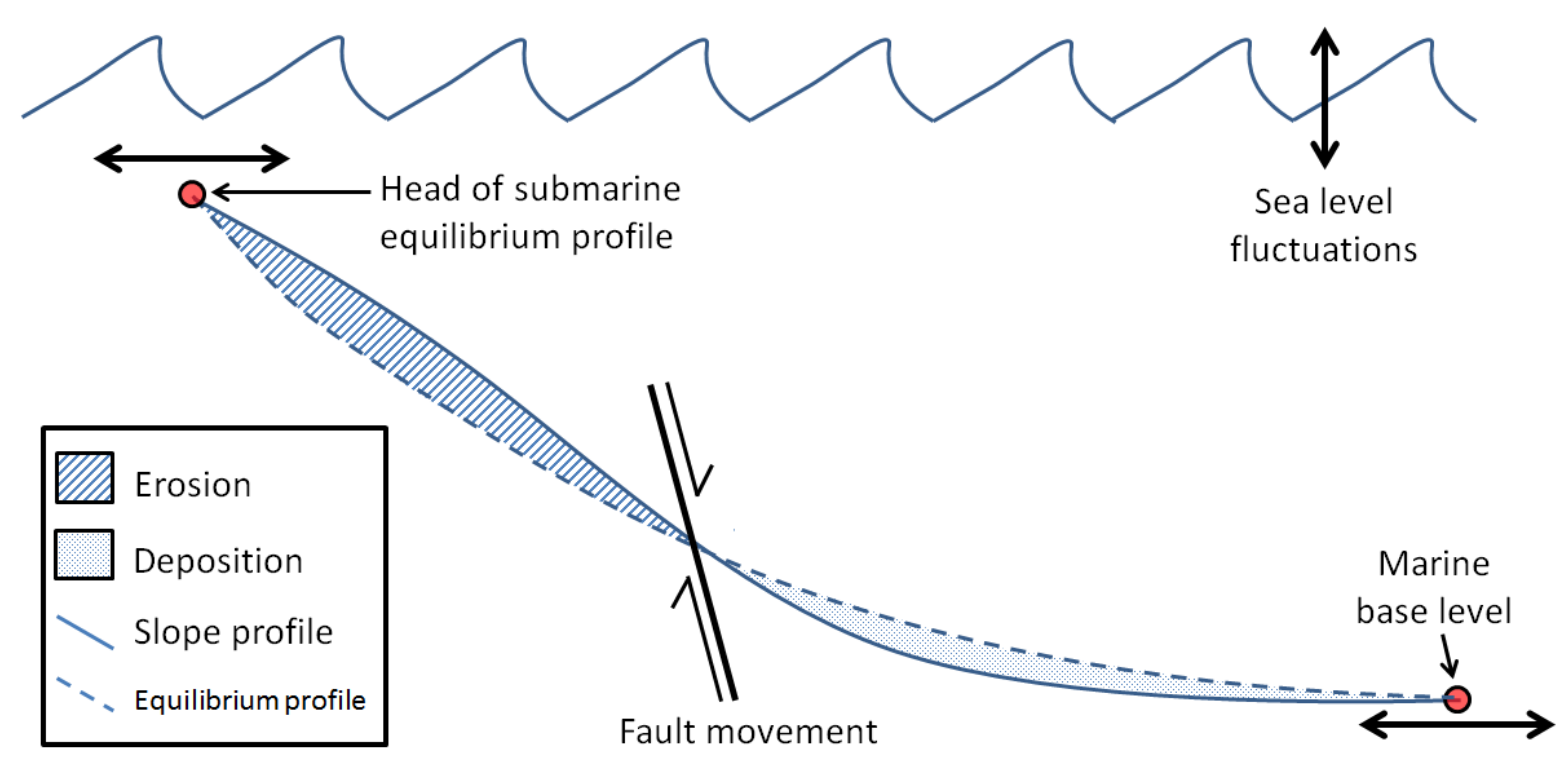

Figure 5.1: Schematic diagram illustrating the mechanisms by which submarine channels are formed. Differences in the marine equilibrium profile and slope profile produce discreet areas of erosion and deposition in order to balance the two curves. The head of the submarine equilibrium profile and marine base level may migrate inward or outward in response to sea level fluctuations, fault movement, erosion and deposition.

One such area of sediment redirection occurred proximal to the Parihaka Fault. A large prograding lobe of sediment to the west of the study area was deposited during the Waipipian (Hansen \& Kamp, 2006a). The lobe is $\sim 40 \mathrm{~km}$-wide, $\leq 200 \mathrm{~ms}$ two-way travel time thick, and was active during deposition of the foresetting sequence in the study area. Simultaneously, the Parihaka Fault was extending and down-faulting the Arawa Sub-Basin. These synchronous processes produced an east-west oriented vertical gradient which produced abundant sediment transport features oriented between SSE and NNE.

Fine- to large-scale channels capable of transporting cubic kilometers of sediment were produced spanning the transition between the northward-prograding shelf and subsiding Arawa Sub-Basin. These channels are discussed in the next section.

\subsection{Mega-Channels}

The three large channels within the study area are positioned within the upper portion of the foresetting sequence of the Giant Foresets Formation, which thickens rapidly over short lateral distances across normal faults and within the primary depocentres in the study area. The mega-channels are oriented parallel to the direction of thickening and were important sediment conduits during the infilling history of the Arawa Sub-Basin. 
The characteristics of the mega-channels observed in Chapter 4 suggest that the channels spanned from the shelf to the basin floor and funnelled sediment down the continental slope, bypassing the prograding foreset beds and transporting sediment directly to the basin floor. Biostratigraphic paleoenvironment determinations show that the feeder channels at the head of the mega-channels sat at shelfal water depths, while mega-channels 2 and 3 reached the toe sets of the foresetting beds, which were deposited near the base of the slope.

These channels formed in response to the creation of accommodation space through normal faulting and subsidence. Accommodation space captures sediment by producing a gradient that attracts sediment into the depression primarily through gravity flows. With large volumes of prograding sediment available at shelfal water depths, and significant space being generated at bathyal water depths, the mega-channels formed to provide a conduit between these two environments.

The size of the channels suggests that they were major sediment transport features. The extensive feeder channel complexes at the head of mega-channel 1 probably funnelled hundreds of cubic kilometers of sediment into the main channel which was then transported into Arawa Sub-Basin.

\section{Formation of the Mega-Channels}

We suggest that mega-channels 1-3 increased in length, width and relief through erosion of underlying strata, remobilisation of sediment, and up-slope incision at the channel head. The morphology and seismic character of the mega-channels observed in seismic profiles and coherency slices indicates a polyphase evolution driven by localised faulting, subsidence and an abundant sediment supply.

Within channel systems, discreet areas of erosion and deposition occur where the slope profile deviates from the equilibrium profile (Fig. 5.1). Erosion and deposition with in the channel occurs between two points - the head of submarine equilibrium profile, and the marine base level (Pirmez et al., 2000). The slope and equilibrium profiles can be balanced more closely by extending the location of the head of submarine equilibrium profile, or the marine base level. 
The concept of a slope equilibrium profile is a useful model when attempting to understand the geomorphology of the mega-channels observed in the study area. An equilibrium profile can be defined as "a depth profile created by the erosional and aggradational action of turbidity currents over a period of thousands of years such that the prevailing sediment discharge is carried through the channel with minimum aggradation or degradation" (Pirmez et al., 2000) (Fig. 5.1). If an equilibrium profile results in "minimum aggradation or degradation" then from this definition it can be reasoned that sea level fluctuations, faulting, erosion and deposition will alter the overall equilibrium profile of the study area, necessitating areas of deposition and erosion of sediment along the length of the channel.

Normal faulting is effective at perturbing the equilibrium profile by increasing the elevation difference between the head and base levels of the profile, creating a steeper overall profile shape. The slope profile becomes more irregular, further increasing the difference between the two profiles and enhancing erosion and deposition.

The direction that the feeder channels to each of the mega-channels appear to originate from is consistent with the position of the sedimentary lobe to the west of the study area, suggesting that the position of the head of the equilibrium profile sits near to this feature. $A$ large-scale sedimentary lobe such as that observed near Taimana-1 would almost certainly require a km-scale distributary channel with associated levee complexes capable of supplying volumes of sediment to the subsiding depocentres to the east.

The proposed sequence of events that produced the mega-channels in the study area is as follows:

1. A large-scale lobe of sediment prograded in a northward direction, to the west of the study area. Concurrently, the Parihaka Fault was extending and generating a kmscale depocentre in the NE of the study area. Sediment was attracted from the paleo-high toward the subsiding Arawa Sub-Basin.

2. One or more nick-points formed on the scarp of the Parihaka Fault (Fig. 5.2a). These grew with increasing fault offset, generating submarine canyon systems with feeder channels at the head and a submarine fan at the toe.

3. As the channel profile became increasingly steep, driven by extensional faulting and subsidence, the head of the submarine equilibrium profile and marine base level 
migrated outward in response (Fig. 5.2a). Increasing perturbations to the submarine equilibrium profile caused outward migration of the equilibrium head and toe points. These generated erosion at the channel head and deposition near the channel toe.

4. The channel profile and equilibrium profile eventually became closely matched and a meandering channel system was established at the base of the mega-channels (Fig. $5.2 b)$.

5. Sediment continued to flow down the channel, infilling the Arawa Sub-Basin and decreasing the overall slope of the profile. The channel head and toe points migrated inwards in response, halting erosion and permitting deposition throughout the mega-channel (Fig. 5.2c).

6. Depocentre is increasingly infilled by sediment as deposition outpaces subsidence of the Arawa Sub-Basin. Large prograding foresets move down the mega-channel, infilling the channel complex (Fig. 5.2c).

7. The mega-channels were infilled and the Arawa Sub-Basin was overlain by top-sets as the shelf-break migrated north and east, further into the North Taranaki Graben.

Determining the evolutionary history and significance of the mega-channels is complicated by the fact that the final configuration of the channel is the only hard evidence that we are afforded. By observing the present day configuration of the mega-channels in three dimensions it is possible to make some conclusions as to the evolution of these features.

The base of each of the mega-channels contains a meandering channel system. Meandering channels require a low channel slope in order to form. Meanders are only observed within the lower most $25-50$ ms of mega-channels 2 and 3 . This indicates that by the time the channel had eroded to near its lowest point, the channel profile had reached a relatively low angle. However this configuration was not sustained for long. 

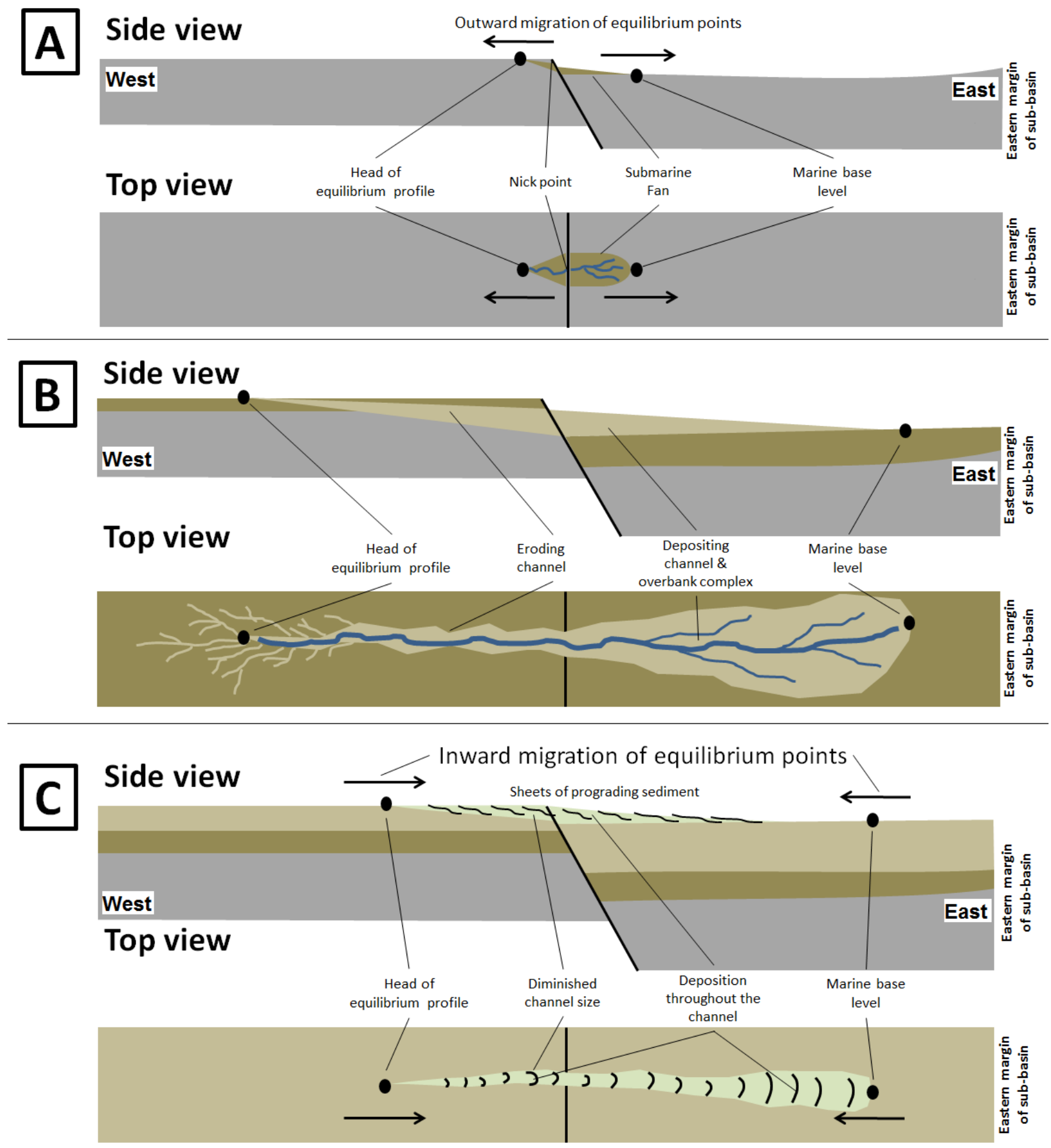

Figure 5.2: Schematic illustration of the evolution of mega-channels in the study area from a side and top view. (a) Genesis and early history of the mega-channels showing growth from an incipient nick-point on the fault. (b) The maximum extent of the mega-channels after normal faulting and resultant erosion and deposition. (c) Eventual infill of the mega-channel as sedimentation outpaces subsidence and faulting. 
Seismic data indicates that the mega-channels were infilled rapidly and chaotically. Moving upwards through the coherency slices, sediment transport features become increasingly rare in mega-channels 2 and 3 . The sediment within the mega-channels do not show any evidence for internal meanders, suggesting that the channel profile became more steeply dipping as the channel was progressively infilled. Seismic facies within these mega-channels is indicative of sheets of sediment prograding rapidly along the length of the channel. Parallel to the length of the channel, seismic facies is similar in appearance to the degradational foreset sequence. The degradational foreset sequence was deposited rapidly by slumping and gravity flows where the slope angle exceeded $3^{\circ}$ (Beggs, 1990). This may be analogous to the infilling history of mega-channels 2 and 3 which share a strikingly similar appearance.

If the channels were infilled chaotically by slumping and gravity flows, the implication is that sediment supply outpaced the subsidence of the sub-basin at the base of the channel. The ability of the channel to progressively extend and erode was driven by continuous displacement along the Parihaka Fault generating accommodation space. The inverse of this, infilling and burial of the mega-channels, must therefore be driven by the opposite process (i.e. outpacing of sediment supply to the sub-basin, infilling accommodation space and reducing the deviation between the equilibrium and slope profiles).

Moving down the length of the channel, mega-channels 2 and 3 both increase in relief toward the halfway point of the channel, then steadily decrease in relief toward the channel termination. From figure 5.1, we see that with increasing offset along the normal faults in the area, the slope profile becomes increasingly detached from the equilibrium profile. This necessitates erosion up-dip of the fault, and deposition down-dip of the fault. However the primary depocentre is itself subsiding variably due to large variations in offset along the length of the Parihaka Fault (Fig. 2.6), as well as uplift of the sedimentary section within the Arawa Sub-Basin in the case of the structural bulge (Figs. 4.2a-c). Consequently, both megachannels 2 and 3 have eroded sediment to the east of the Parihaka Fault.

Mega-channel 3 has eroded for many kilometers into the Arawa Sub-Basin. This deviates from the model, which predicts deposition beyond the fault which is perturbing the slope profile. However mega-channel 3 crosses the fault at a point which has experienced minimal 
offset. To the north, fault offsets increase by an order of magnitude, indicating that subsidence within the Arawa Sub-Basin would have also been disturbing the slope profile. Consequently, it appears that sub-basin subsidence, rather than localised faulting, played the largest role in the evolution of mega-channel 3.

Migration of the outer points of the equilibrium profile is hypothesised to have primarily occurred at the channel head. This is supported by the morphology of the observed feeder channel complexes. Increased conformance between the two profiles is achieved by increasing the distance between the head of the equilibrium profile and the marine base level (Fig. 5.1). The base of the equilibrium profile however may have been partially constrained by the eastern margin of the depocentre. This could have necessitated up-dip incision of feeder channel complexes at the head of the mega-channels in order to increase conformance between the equilibrium and slope profiles.

\section{Significance of Mega-Channel 1}

Mega-channel 1 is anomalous because it deflects away from the primary depocentre, and exits the northern edge of the study area. Assuming a similar evolutionary sequence to the other mega-channels, some conclusions can be drawn from our observations. The linear increase in relief observed within this channel suggests that less than two thirds of the total channel length is present within the study area. In addition, a channel of this size is likely to be connected to, and funnelling sediment into, a sizeable subsiding depocentre to the north. However, the presence of numerous meanders from the channel base through to the middle levels of the mega-channel suggests that the profile of the channel remained at a low angle for longer than the other channels.

A large deviation from the equilibrium profile would be required to produce a channel relief of $300+$ ms two-way travel time observed in seismic section. Mega-channel 1 reaches roughly the same relief as mega-channel 3 does near the eastern edge of the Parihaka 3D survey, which might indicate one of two cases:

1. Mega-channel 1 is close to the depocentre and will begin to decrease in relief soon; or 
2. Mega-channel 1 is far from the depocentre and will continue to increase in relief for an unspecified distance before decreasing in relief as it nears the depocentre.

The age of mega-channel 1 is Waipipian-Mangapanian in age which leaves a broad area to the south of the Kora volcanic complex as a possible depocentre location (Fig. 2.10).

One possibility is that this channel is not related to faulting, but is in fact feeding the progradation of the continental shelf. The channel sits near the basal top-set horizon. The shelf break was very near to the study area at the time that this horizon was deposited, and probably sat within the study area during the period mega-channel 1 was active. As such, the channel would have spanned the transition from shelf to slope, and perhaps to the basin floor. Its large size suggests that it was an important conduit for sediment which makes this a distinct possibility.

The bend in mega-channel 1 that occurs near segment III of the Parihaka Fault may have formed while the head of the channel was eroding up-dip during the channel growth phase. If the channel head was eroding southwards, when it approached the fault scarp it would have likely needed to begin eroding in the direction of the supply of sediment, which was to the west. Consequently, it may be coincidental rather than causal that the channel bends in close proximity to the Parihaka Fault. Alternatively, uplift of the footwall block close to the fault may have created a barrier to sediment flow. This segment of the Parihaka Fault has the highest displacement, and consequently uplift of the footwall in close proximity to the fault could have certainly occurred.

\section{Interaction of the Parihaka Fault}

It is apparent from the evidence stated above that the Parihaka Fault was actively deforming at the same time that mega-channels 1-3 were actively transporting sediment. Primary lines of evidence that support this conclusion include:

1. Isochore maps show that the primary depocentre underwent the greatest amount of thickening during the Waipipian-Mangapanian; the same period that the megachannels were active.

2. All channels show evidence of significant deflection in close proximity $(<2 \mathrm{~km})$ to the fault trace. 
a. Mega-channel 1 bends in close proximity to segment III of the Parihaka Fault, as discussed above.

b. The orientation of mega-channel 2 rotates toward segment II of the Parihaka Fault as it approaches the fault, and then rotates to the north into the primary depocentre after crossing the fault.

c. Mega-channel 3 follows the fault trace of segment I of the Parihaka Fault for as far as $10 \mathrm{~km}$ before entering the primary depocentre at a point where the fault begins to accrue a larger amount of offset.

This evidence suggests that the Parihaka Fault affected the evolution of the mega-channels. The close match between mega-channel 3 and the southern portion of segment I of the Parihaka Fault is striking and poses the question of how the channel manages to cross the fault numerous times.

Figure 2.6 indicates that up to $400 \mathrm{~m}$ of slip occurred during the Pliocene along the portion of the fault that mega-channel 3 channel follows. Presumably, the channel and fault evolved in tandem, allowing the channel to continuously erode the fault scarp as it was created. The extensive feeder channel complex to the west of the fault very likely played an important role in eroding and smoothing the scarp after each earthquake. Interestingly, the northernmost position of the feeder channels is also the same place at which mega-channel 3 deviates from the fault, supporting this hypothesis.

In the case of mega-channel 2 , the channel crosses the fault at the same location that a fault scarp slump has originated from. This feature is discussed in section 4.6. The slump occurred very close to the same time period that mega-channel 2 was active, and these features are probably closely connected. One possible scenario is that as mega- channel 2 crossed the fault and grew in size, the surrounding fault scarp was destabilised. This caused a mass failure of sediment from the fault scarp in the Arawa Sub-Basin, creating the observed slump feature.

\section{Influence of Volcanic Intrusions}

The Southern Intrusive Complex was emplaced after the deposition of the foresetting sequence, likely becoming inactive at 3-1 Ma (Luke, 2012). Luke (2012) finds that the 
volcanic massif did not reach the surface and was intrusive. The Southern Intrusive Complex has strongly domed the basal foreset horizon and penetrated through it in places, suggesting that if it were truly intrusive, it was is younger than $3.7 \mathrm{Ma}$. This is in agreement with previous estimates (e.g. Luke, 2012; Giba et al., 2013).

Seismic profiles and coherency cube slices indicate that the Southern Intrusive Complex almost certainly affected sediment transport within the study area during deposition of the foreset and top-set sequences. The intrusion appears to have been actively intruding during the deposition of the foresetting sequence, but continued to affect the flow of sediment beyond 2.0 Ma. Buoyant magma rising to near the surface associated with the Mohakatino Volcanics has been previously suggested as a barrier to sediment flow via doming of the seabed (King \& Thrasher, 1996; Hansen \& Kamp, 2002).

Evidence for the Southern Intrusive Complex providing a barrier to sediment transport during the Waipipian-Mangapanian comes from channels appearing to bend around the SE extent of the intrusion in the overlying sedimentary section. Fine-scale channelling appears to wrap around the outline of the intrusion near the southern apophysis of the Southern Intrusive Complex at the stratigraphic level of the basal top-set horizon. This channelling was probably influenced by doming of the sedimentary section caused by emplacement of buoyant magma.

The Southern Intrusive Complex may have also funnelled sediment toward the primary depocentre. A syncline has formed between the Parihaka Fault and the Southern Intrusive Complex, which is closely matched by the position of mega-channel 3. At least two other large channels observed near the eastern edge of the study area appear to be oriented parallel to the axis of the syncline (Figs. 4.5g-h).

To the northeast of the primary depocentre, a large volcanic intrusion (maximum diameter $11.8 \mathrm{~km}$ ) roughly dated to $\sim 8-5.5 \mathrm{Ma}( \pm 1-2 \mathrm{Ma}$ ) is observed within 2D seismic data (Giba et al., 2013). The age and volume of this intrusive complex indicates that, much like the Southern Intrusive Complex, this intrusion probably also had a surface expression. Thinning of the foreset and top-set sequences overlying the intrusion is observed in 2D seismic, however the available grid of 2D seismic lines overlying the intrusion is sparse and none adequately capture the full extent of this thinning. 
The possibility that the eastern volcanic intrusion bounded the Arawa Sub-Basin and helped to capture sediment within the depocentre is further supported by the observation that large channels entering the depocentre diminish greatly over a relatively short distance within the depocentre as they approach the intrusion to the NE. Mega-channel 3 is observed to maintain a consistent size within the Arawa Sub-Basin for $15-20 \mathrm{~km}$. It then spreads and thins rapidly in width and relief over $\sim 7-10 \mathrm{~km}$ as it merges with the surrounding reflection events.

\section{Parihaka Fault Structural Bulge}

The structural bulge to the east of Parihaka Fault segments III and IV, where the fault strike curves from NNE to ENE was generated as a result of the space problem created by a series of normal faults dipping inward toward one another. The downthrown block has limited space in which to subside, creating a structural bulge at the location where space is most constrained.

This bulge appears to have affected channel orientation and impeded the free flow of sediment within the downthrown block. In the foresetting sequence isochore, sediment thickness notably thins overlying the structural bulge. In comparison, thinning overlying the bulge is not present over the lower top-set interval.

Mega-channel 2 does not appear to be impeded by the structural bulge. This channel crosses the bulge with little or no apparent deflection as it enters the primary depocentre. In each isochore map, thinning of the sedimentary section overlying with the structural bulge is extended in the direction of the channel termination. This could indicate that megachannel 2 was gradually eroding some of the sediment overlying the uplifted bulge and transporting it further into the depocentre.

\section{$\underline{5.4 \text { Seismic Interpretation }}$}

\section{Experimental Set-Up}

In order to systematically explore the nature of the observed mega-channels, and their interaction with the Parihaka Fault, it was necessary to include a wide range of data types in the study. Original well completion reports and more recent supplementary reports were 
used to compile a comprehensive set of geological and geophysical well data. Well data types employed in this study are biostratigraphy, lithostratigraphic divisions, and time-depth data and deviation curves.

Biostratigraphic data was taken from a 2006 study undertaken by GNS which included standard event biostratigraphy and age correlation of the four key wells within the study area, complementing a CONOP derived correlation of these events and ages (PR3534). GNS employed modern techniques and looked at the Miocene-Pleistocene interval, for all four key wells in the study area. The study included an additional 90 new sample examinations from near or at event boundaries. Biostratigraphy is therefore considered high quality and containing minimal error aside from uncertainties inherent in this technique.

Lithostratigraphic divisions used in this study formed a minor component of the overall study. This study focussed on just one formation, which sits at the top of the stratigraphic sequence in the Taranaki Basin. As such, the lower boundary was the only uncertain lithostratigraphic division. Addressing the transition from the Giant Foresets Formation to the underlying formation(s) was simplified by the observation that planktic percentages decrease rapidly within the Giant Foresets Formation (Hansen \& Kamp, 2002). This is due to the slow sedimentation rates of the underlying formations relative to the Giant Foresets Formation, which allows more time for planktic species to concentrate in the sediment. Consequently, the formation boundary was well defined in all key wells.

Wells that were displayed against seismic required deviation curve data in order to display biostratigraphic and lithostratigraphic data accurately. Generally, these data types are provided as measured depths from a reference elevation on the drilling rig, such as the "kelly bushing" or "rotary table". Marine seismic data, in comparison, is generally datumed at sea level and displayed vertically in the time or depth domains. Conflict arises from the fact that all wells deviate from perfectly vertical with increasing depth, therefore converting between the depths measured from the reference elevation and the true vertical depth below sea level requires an understanding of how far a well has deviated from vertical. Using the deviation curve, the geological well data can be displayed at the correct location on the seismic data, enhancing the accuracy of the derived interpretations. 


\section{Seismic Interpretation}

The basal foreset and basal top-set horizons were selected because they correspond to important transition periods in the evolution of the foresetting sequence within Giant Foresets Formation. A third intra-top-set horizon allowed the $\sim 500-2000 \mathrm{~m}$ thick top-set sequence to be divided into a more easily interpreted set of two intervals, which also provides temporal constraints on the evolution of the top-sets sequence.

When selecting which reflection event to pick a strong reflection signal and large lateral extent were the most important considerations. These criteria were chosen due to the observation that highly reflective events tend to be more widely continuous in the study area. As noted by Beggs (1990), strong reflection events arise from partial lithification during sea-level highstands which cause periods of non-deposition. Consequently, a single strong and continuous reflection event can be considered nearly isochronous. This places stronger temporal constraints on the study.

The intra-top-set and basal top-set reflection events were easily traced across the majority of the study. This is due to the highly continuous, planar and coherent seismic facies of the top-set sequence. The basal top-set reflector chosen at Arawa-1 dipped away sharply at the northern edge of the study area as the top-set reflector transitioned into a foresetting bed. This dipping reflector represents the previous position of the shelf break, at the time of deposition of that reflector, $\sim 2.4 \mathrm{Ma}$ ago.

Within the primary depocentre, along the eastern margin of the 3D survey, the basal top-set horizon entered the transition between the top-set and degradational foresetting sequences. Here, it became discontinuous and frequently channel cut. These issues were mitigated by picking parallel to, and at a constant depth below, the overlying top-set reflectors.

The basal foreset reflector was the least continuous of the three main horizons. This is a consequence of the foresetting nature of this sedimentary package. The reflection event downlapped onto lower reflection events several times and entered chaotic and discontinuous seismic facies within the primary depocentre. Tracking the base of the foresetting sequence was achieved by visually evaluating the seismic facies and judging the 
approximate position of the base of the sequence. This frequently required jumping upwards or downwards to adjacent reflection events as appropriate.

All horizons could not to be effectively picked in the SE corner of the 3D seismic survey, near the Okoki-1 well, due to the chaotic and discontinuous seismic facies which dominates the Pliocene-Recent section in this area. This seismic facies is a consequence of Late MiocenePliocene uplift of the Taranaki Peninsula, linked to the uplift of the central North Island and Southern Alps (Armstrong et al., 1998). More than $1000 \mathrm{~m}$ of uplift is estimated to have occurred at the location of Okoki-1 associated with this tectonic event.

\section{Well Correlation}

Once reflection events were chosen at the Arawa-1 well location, a well correlation was made with the Taimana-1 and Witiora-1 wells along an arbitrarily chosen seismic line (Fig. 4.1a). The correlation between Arawa-1 and Taimana-1 along a single consistent reflection event was possible for all horizons, and the age ranges were a good match in both wells.

The correlation between Arawa-1 and Witiora-1 was only possible along a single consistent reflection event for the basal top-set and intra-top-set horizons. The basal foreset reflection event was disrupted by a seismic facies characterised by poorly continuous, semi-chaotic reflection events proximal to the Witiora-1 well. However all horizons were good age matches in both Arawa-1 and Witiora-1.

The Arawa-1 to Okoki-1 well correlation was not possible for all horizons (Fig. 4.1b). The failure to correlate Arawa-1 to Okoki-1 was due to strongly tilted strata that subcropped and terminated beneath the overlying $200 \mathrm{~ms}$ two-way time of sediment. The tilting and erosion of strata near Okoki-1 was caused by uplift of the Taranaki Peninsula as discussed above.

\section{Gridding}

The gridding process was undertaken using an iterative approach with the aim of finding the closest match between the selected reflection event and the grid produced from the input seed lines (i.e. picks made on every 50 inline/crossline). Settings were adjusted in small increments and the match was visually evaluated on a crossline evenly spaced between two 
seed lines. Crosslines were used during this process as they intersected the greatest number of faults, which were the areas that generated the largest mismatches. Final settings are available in appendix figure C.8.

\section{Depth Conversion}

Depth conversion of the grids and isochore maps was undertaken using a $3^{\text {rd }}$ order polynomial equation derived from the seismic time-depth curve of Arawa-1. The Arawa-1 well was chosen to represent the velocity structure of the study area due to its central location and simple penetrated sedimentary section.

An evaluation of the validity of the equation was made using time-depth curves sourced from vertical seismic profiles taken at Arawa-1, Taimana-1, Witiora-1, Taranga-1 (west of study area), Kanuka-1 (north of study area) and Albacore-1 (NE of study area) as well as Okoki-1. The upper $3 \mathrm{~km}$ of sediment penetrated by each of these wells, with the exception of Okoki-1, showed an excellent consistency in the velocity structure over lateral distances of $\sim 90 \mathrm{~km}$, far beyond the boundary of the study area.

The Okoki-1 well shows a large variation in velocity structure from $\sim 400 \mathrm{~m}$ below sea level onwards. This is attributed to uplift at the location of the present day onshore Taranaki Peninsula and along the eastern margin of the basin. Uplift was accompanied by erosion which is evident in the steeply dipping, sub-cropping strata near Okoki-1 on the ArawaOkoki tie-line (section 4.x). Deeply buried and compacted sediment, with a higher internal seismic velocity, was uplifted and exhumed, causing an anomalous velocity structure to the south of the study area. To a much lesser degree, the effects of the uplift can be seen in the next most southerly well, Witiora-1, which shows a slightly faster time-depth curve than the more northerly wells.

\section{Contouring}

Contouring was the final step applied to the grids and isochore maps. The intention of the contouring process was to find a moderate contour spacing and large label size appropriate to the range of depths that each of the grids spanned. This required an iterative approach, using a visual evaluation to find the best settings. The contouring process is used to enhance 
the information presented in grids and isochores to make them more easily visually understood.

\section{Depth Maps and Isochores}

Depth maps and isochores are important tools for visualising deformation and sedimentation patterns. The depth maps illustrate the present day configuration of the picked horizon while isochore maps show the difference between two depth maps, and represent interval sediment thicknesses. The depth maps and isochores were converted from the time domain to the depth domain as vertical velocity variations can subdue or exaggerate features in the time domain.

The near basal foresets grid illustrates the areas that have experienced the most intense faulting, subsidence and compaction within the Parihaka 3D seismic survey in the last $~ 3.7$ Ma. All of these depocentres are obviously fault-controlled, with each being dominantly bounding on the NW margin by a SE-dipping, SW-NE striking normal fault.

The large primary depocentre in the NE of the survey is highly depressed relative to the surrounding area. Assuming an approximately flat seafloor at the time of deposition, up to $2000 \mathrm{~m}$ of subsidence has occurred over the following $\sim 3.7 \mathrm{Ma}$, an extensional offset rate of $\ll 1 \mathrm{~mm} / \mathrm{yr}$. This is extremely slow when placed alongside other currently active extensional fault systems in New Zealand. In comparison, faults bounding the Taupo Volcanic Zone experience $12-15 \mathrm{~mm} / \mathrm{yr}$ of extensional offset (Lamarche et al., 2006).

The overlying basal top-set depth grid is very similar to the grid below, and demonstrates the same major features; however the fault offsets are significantly reduced when compared to the basal foreset grid. Still evident is the primary depocentre and secondary elongate depocentre in the south, however these are both comparatively subdued in their vertical expression. The Southern Intrusive Complex does not penetrate this horizon, although it does strongly dome it.

The shelf break is evident in the northern corner of the 3D survey in the basal top-set depth grid. This is entirely expected, as the basal top-set reflection event at Arawa-1 would indicate that the foresetting sequence had only recently prograded across this area. 
The intra-top-set depth grid again exhibits many of the features observed in the previous grids. Chief amongst these is the primary depocentre, which is subdued compared to the basal top-set grid. There is only $\sim 300 \mathrm{~m}$ of fault offset across the Parihaka Fault at this stratigraphic level compared to up to $2000 \mathrm{~m}$ at the level of the basal foreset horizon. This would indicate that the primary depocentre experienced the overwhelming majority of subsidence during the foresetting and early top-setting period - Up to $1700 \mathrm{~m}$ vertical fault offset in $\sim 1.7$ Ma vs. $\sim 300 \mathrm{~m}$ vertical fault offset in $\sim 2.0 \mathrm{Ma}$.

\subsection{Summary}

The interaction of the Giant Foresets Formation and the Parihaka Fault during the Pliocene has produced $\mathrm{km}$-scale mega-channels that form major conduits between the shelf and basin floor within the study area. These large-scale channels have also provided sediment to the subsiding depocentre in the NE of the study area, the Arawa Sub-Basin. A $40 \mathrm{~km}$ wide lobe of northward prograding sediment near Taimana-1 supplied volumes of sediment which have been attracted perpendicular to, and even counter to, the primary direction of sediment transport which is primarily to the NNW.

Mega- channels formed through a polyphase process of erosion, channel growth and eventual infill and burial. Nick points on the fault scarp were extended through a process of channel head back-cutting and submarine fan growth driven by continued extension on the Parihaka Fault and subsidence within the Arawa Sub-Basin. The balance between deposition and subsidence was eventually tipped in the favour of sedimentation, infilling the megachannels and overtopping the Arawa Sub-Basin.

The previously unnamed Arawa Sub-Basin is a fault-bounded depression with large volcanic intrusions at the eastern and southern margins. These volcanic intrusions show evidence for uplift and doming of the seafloor which has inhibited the flow of sediment, enhancing the capture of sediment with the sub-basin. 


\section{Conclusion}

The Parihaka 3D and ES89 2D seismic surveys were studied in order to understand the interaction of the foresetting sequence of the Giant Foresets Formation and the Parihaka Fault, at the SW termination of the North Taranaki Graben. Biostratigraphy, lithostratigraphic determinations and time-depth and deviation data from exploration wells in the area was also utilised to provide physical information about the geology in the area and to place greater temporal constraints upon the study.

Primary outputs from the seismic interpretation study were depth grid maps, isochore maps spanning important intervals, coherency cube time-slices and seismic sections from the Parihaka 3D and ES89 2D seismic surveys.

Mega-channels within the foresetting sequence of the Giant Foresets Formation are oriented perpendicular to, and occasionally opposite to the prevailing sediment transport direction. These kilometer-scale channels interact with the Parihaka Fault and enter the newly named Arawa Sub-Basin, which sits at the NE corner of the study area.

Key findings from this study are:

1. Large-scale mega-channels formed in response to the interaction of sediment supply from the south and west, and faulting and subsidence within the North Taranaki Graben, particularly the Arawa Sub-Basin.

2. The mega-channels underwent a polyphase evolution during the WaipipianMangapanian starting with incision, channel growth and eventual infilling and burial of the channels.

3. The Arawa Sub-Basin was bounded to the north and west by the Parihaka Fault, and to the south and east by volcanic intrusions of the Mohakatino Volcanic Formation which uplifted and domed the seafloor, enhancing sediment entrapment within the sub-basin. 


\section{References}

ARCO Petroleum (1992). Arawa-1 Final well report PPL38436. Unpublished New Zealand Petroleum Report 1824, New Zealand Petroleum \& Minerals, Wellington.

Armstrong, P. A., Allis, R. G., Funnell, R. H., \& Chapman, D. S. (1998). Late Neogene exhumation patterns in Taranaki Basin, New Zealand: Evidence from offset porositydepth trends. Journal of Geophysical Research, 103(B12), 30269-30282.

Bacon, M., Simm, R., \& Redshaw, T. (2003). 3-D Seismic Interpretation. Cambridge, UK: Cambridge University Press.

Bahorich, M., \& Farmer, S. (1995). The Coherence Cube. The Leading Edge, 14(10), 10531058.

Bates, R., \& Heid, M. (2007). Kanuka-1 End of Well Completion Report. Unpublished New Zealand Petroleum Report 3843, New Zealand Petroleum \& Minerals, Wellington.

Beggs, J. M. (1990). Seismic Stratigraphy of the Plio-Pleistocene Giant Foresets Formation, Western Platform, Taranaki Basin. 1989 New Zealand Oil Exploration Conference Proceedings, 201-207.

Boggs Jr., S. (2006). Principles of sedimentology and stratigraphy (4th ed.). Upper Saddle River, New Jersey, USA: Pearson Prentice Hall.

Childs, C., Walsh, J. J., Manzocchi, T., Strand, J., Nicol, A., Tomasso, M., Schöpfer, M. P. J., Aplin, A. C. (2007). Definition of a fault permeability predictor from outcrop studies of a faulted turbidite sequence, Taranaki, New Zealand. Geological Society, London, Special Publications, 292(1), 235-258.

Diamond Shamrock Exploration Oil Co (NZ) International Department (1984). Final Well Report Taimana-1 PPL 38109. Unpublished New Zealand Petroleum Report 1026, New Zealand Petroleum \& Minerals, Wellington.

Funnell, R. H., Chapman, D., Allis, R., \& Armstrong, P. (1996). Thermal state of the Taranaki Basin, New Zealand. Journal of Geophysical Research: Solid Earth, 101(B11), 2519725215.

GECO NZ (1989). ES89 seismic survey. PPL38439, PPL38451 and PPL38452. Unpublished New Zealand Petroleum Report 1978, New Zealand Petroleum \& Minerals, Wellington.

Giba, M., Nicol, A., \& Walsh, J. J. (2010). Evolution of faulting and volcanism in a back-arc basin and its implications for subduction processes. Tectonics, 29(4), TC4020.

Giba, M., Walsh, J. J., \& Nicol, A. (2012). Segmentation and growth of an obliquely reactivated normal fault. Journal of Structural Geology, 39, 253-267. 
Giba, M., Walsh, J. J., Nicol, A., Mouslopoulou, V., \& Seebeck, H. (2013). Investigation of the spatio-temporal relationship between normal faulting and arc volcanism on millionyear time scales. Journal of the Geological Society, 170, 951-962.

Hansen, R. J. (2003). Characteristics and evolution of a dynamic prograding continental margin: the late Neogene Giant Foresets Formation, northern Taranaki Basin, New Zealand (Unpublished doctoral thesis). Waikato University, Hamilton, New Zealand.

Hansen, R. J., \& Kamp, P. J. J. (2002). Evolution of the Giant Foresets Formation, northern Taranaki Basin, New Zealand. Proceedings of New Zealand Petroleum Conference, 2002, 419-435.

Hansen, R. J., \& Kamp, P. J. J. (2004a). Late Miocene to early Pliocene stratigraphic record in northern Taranaki Basin: Condensed sedimentation ahead of Northern Graben extension and progradation of the modern continental margin. New Zealand Journal of Geology and Geophysics, 47(4), 645-662.

Hansen, R. J., \& Kamp, P. J. J. (2004b). Rapid progradation of the Pliocene-Pleistocene continental margin, northern Taranaki Basin, New Zealand, and implications. Proceedings of New Zealand Petroleum Conference, 2004.

Hansen, R. J., \& Kamp, P. J. J. (2006a). An integrated biostratigraphy and seismic stratigraphy for the late Neogene continental margin succession in northern Taranaki Basin, New Zealand. New Zealand Journal of Geology and Geophysics, 49, 39-56.

Hansen, R. J., \& Kamp, P. J. J. (2006b). Sequence stratigraphy and architectural elements of the Giant Foresets Formation, northern Taranaki Basin, New Zealand. Proceedings of New Zealand Petroleum Conference, 2006.

Holt, W. E., \& Stern, T. A. (1991). Sediment loading on the Western Platform of the New Zealand continent: Implications for the strength of a continental margin. Earth and Planetary Science Letters, 107, 523-538.

Holt, W. E., \& Stern, T. A. (1994). Subduction, platform subsidence, and foreland thrust loading: The late Tertiary development of Taranaki Basin, New Zealand. Tectonics, 13(5), 1068-1092.

Hood, S. D., Nelson, C. S., \& Kamp, P. J. J. (2003). Lithostratigraphy and depositional episodes of the Oligocene carbonate-rich Tikorangi Formation, Taranaki Basin, New Zealand. New Zealand Journal of Geology and Geophysics, 46(3), 363-386.

Hooke J. M. (2007). Complexity, self-organisation and variation in behaviour in meandering rivers. Geomorphology, 91(3-4), 236-258. 
Kamp, P. J. J., Vonk, A. J., Bland, K. J., Hansen, R. J., Hendy, A. J. W., McIntyre, A. P., Ngatai, M., Cartwright, S. J., Hayton, S. \& Nelson, C. S. (2004). Neogene stratigraphic architecture and tectonic evolution of Wanganui, King Country, and eastern Taranaki Basins, New Zealand. New Zealand Journal of Geology and Geophysics, 47(4), 625644.

Killops, S. D., Reyes, A., \& Funnell, R. H. (2009). Filling History of the Maui B Field, New Zealand: New information from oil inclusions in authigenic minerals from the oil leg in the Maui-B1 well F-Sands. Journal of Petroleum Geology, 32(3), 271-286.

King, P. R. (2000). Tectonic reconstructions of New Zealand $40 \mathrm{Ma}$ to the present. New Zealand Journal of Geology and Geophysics, 43(4), 611- 638.

King, P. R., \& Thrasher, G. P. (1996). Cretaceous-Cenozoic geology and petroleum systems of Taranaki Basin, New Zealand. Unpublished petroleum report 4527, New Zealand Petroleum \& Minerals, Wellington.

Lamarche, G., Barnes, P. M., \& Bull, J. M. (2006). Faulting and Extension Rate over the last 20,000 Years in the Offshore Whakatane Graben, New Zealand Continental Shelf. Tectonics, 25(4).

Lamb, S. (2011). Cenozoic tectonic evolution of the New Zealand plate-boundary zone: A paleomagnetic perspective. Tectonophysics, 509(3-4), 135-164.

Luke, J. (2013). Three-Dimensional Seismic Study of Pluton Emplacement, Offshore Northwestern New Zealand (Unpublished master's thesis). Brigham Young University, Utah, USA.

Manzocchi, T., Walsh, J. J., \& Nicol, A. (2006). Displacement accumulation from earthquakes on isolated normal faults. Journal of Structural Geology, 28(9), 1685-1693.

Mayall, M., Jones, E., \& Casey, M. (2006). Turbidite channel reservoirs-Key elements in facies prediction and effective development. Marine and Petroleum Geology, 23(8), 821-841.

Mills, C.R. (1990). Gravity expression of the Patea-Tongaporutu High and subsequent model for the Taranaki Basin margin. New Zealand Petroleum Exploration Conference Proceedings, 1989, 191-200.

Mills, C.R. (2002). Good as Goldie: the Goldie prospect from seismic to production. New Zealand Petroleum Conference Proceedings, 2002, 66-80.

Milner, M., Massey, M., Jones, C., \& Viskovic, P. (2010). Offshore Taranaki phase-matched seismic database. GNS Science data series $3 a$. 
Morgans, H. (2006). Foraminiferal Biostratigraphy of the early Miocene to Pleistocene Sequences in Witiora-1, Taimana-1, Arawa-1 and Okoki-1. Unpublished New Zealand Petroleum Report 3534, New Zealand Petroleum \& Minerals, Wellington.

Mouslopoulou, V., Nicol, A., Walsh, J. J., Begg, J. G., Townsend, D. B., \& Hristopulos, D. T. (2012). Fault-slip accumulation in an active rift over thousands to millions of years and the importance of paleoearthquake sampling. Journal of Structural Geology, 36, 71-80.

Muir, R. J., Bradshaw, J. D., Weaver, S. D., \& Laird, M. G. (2000). The influence of basement structure on the evolution of the Taranaki Basin, New Zealand. Journal of the Geological Society, 157(6), 1179-1185.

Murray, D., \& de Bock, J. F. (1996). Awatea-1 Well Completion Report, PEP38457. Unpublished New Zealand Petroleum Report 2262, New Zealand Petroleum \& Minerals, Wellington.

New Zealand Oil \& Gas Ltd (1984). Witiora-1 completion report, PPL 38113. Offshore Taranaki. Unpublished Petroleum Report 1037, New Zealand Petroleum \& Minerals, Wellington.

New Zealand Petroleum \& Minerals (2013). 2013 Block Offer Taranaki Area Petroleum Geological Summary. Retrieved from www.nzpam.govt.nz.

Nodder, S. D. (1993). Neotectonics of the offshore Cape Egmont Fault Zone, Taranaki Basin, New Zealand. New Zealand Journal of Geology and Geophysics, 36(2), 167-184.

Nodder, S. D. (1994). Characterizing potential offshore seismic sources using high-resolution geophysical and seafloor sampling programs: An example from Cape Egmont fault zone, Taranaki shelf, New Zealand. Tectonics, 13(3), 641-658.

Pilar, W. F. H., \& Wakefield, L. L. (1978). Structural and stratigraphic evolution of the Taranaki Basin, offshore North Island, New Zealand. Australian Petroleum Exploration Journal, 18, 93-101.

Pirmez, C., Beaubouef, R. T., Friedman, G. M., \& Mohrig, D. C. (2000). Equilibrium profile and baselevel in submarine channels: examples from Late Pleistocene systems and implications for the architecture of deepwater reservoirs. In P. Weimer, R. M. Slatt, J. M. Coleman, N. C. Rosen, H. Nelson, A. H. Bouma, M. J. Stytzen \& D. T. Lawrence (Eds.), Deep-Water Reservoirs of the World. Gulf Coast Section SEPM, Houston, Texas (pp. 782-805).

Posamentier, H. W., \& Venkatarathnan, K. (2003). Seismic geomorphology and stratigraphy of depositional elements in deep-water settings. Journal of Sedimentary Research, 73(3), 367-388. 
Pulford, A., \& Stern, T. A. (2004). Pliocene exhumation and landscape evolution of central North Island, New Zealand: The role of the upper mantle. Journal of Geophysical Research, 109.

Reilly, C., Nicol, A., \& Walsh, J. J. (2014, April). Evolution of faults in the Southern Taranaki Basin since the late Cretaceous; implications for hydrocarbon migration and accumulation. Paper presented at the Advantage NZ: Geotechnical Petroleum Forum 2014. Retrieved from www.nzpam.govt.nz/cms/pdf-library/advantage$\mathrm{nz} /$ papers/session-6-cathal-reilly-paper-908-kb-pdf/

Sherburn, S., \& White, R. S. (2005). Crustal seismicity in Taranaki, New Zealand using accurate hypocentres from a dense network. Geophysical Journal International, 162(2), 494-506.

Sherburn, S., White, R. S., \& Chadwick, M. (2006). Three-dimensional tomographic imaging of the Taranaki volcanoes, New Zealand. Geophysical Journal International, 166(2), 957-969.

Stagpoole, V., \& Funnell, R. H. (2001). Arc magmatism and hydrocarbon generation in the northern Taranaki Basin, New Zealand. Petroleum Geoscience, 7(3), 255-267.

Stagpoole, V., \& Nicol, A. (2008). Regional structure and kinematic history of a large subduction back thrust: Taranaki Fault, New Zealand. Journal of Geophysical Research, 113, B01403.

Stern, T. A., \& Davey, F. J. (1990). Deep seismic expression of a foreland basin: Taranaki basin, New Zealand. Geology, 18(10), 979-982.

Stern, T. A., Smith, E. G. C., Davey, F. J., \& Muirhead, K. J. (1987). Crustal and upper mantle structure of the northwestern North Island, New Zealand, from seismic refraction data. Geophysical Journal of the Royal Astronomical Society, 91(3), 913-936.

Stern, T. A., Stratford, W. R., \& Salmon, M. L. (2006). Subduction evolution and mantle dynamics at a continental margin: Central North Island, New Zealand. Reviews of Geophysics, 44(4), RG4002.

TCPL Resources Ltd (1989). Well Completion Report Okoki-1 PPL38438. Unpublished Petroleum Report 1495, New Zealand Petroleum \& Minerals, Wellington.

Thrasher, G. P. (1992). Late Cretaceous source rocks of the Taranaki Basin. New Zealand Oil Exploration Conference Proceedings, 1991, 147-154.

Veritas (2005). Parihaka 3D Marine Seismic Survey - Acquisition and Processing Report. Unpublished New Zealand Petroleum Report 3460, New Zealand Petroleum \& Minerals, Wellington. 
Wallace, L. M., Barnes, P., Beavan, J., Van Dissen, R., Litchfield, N., Mountjoy, J., . . Pondard, N. (2012). The kinematics of a transition from subduction to strike-slip: An example from the central New Zealand plate boundary. Journal of Geophysical Research: Solid Earth, 117(B2), B02405.

Wallace, L. M., Beavan, J., McCaffrey, R., \& Darby, D. (2004). Subduction zone coupling and tectonic block rotations in the North Island, New Zealand. Journal of Geophysical Research: Solid Earth, 109(B12), B12406.

Walsh, J. J., \& Watterson, J. (1991). Geometric and kinematic coherence and scale effects in normal fault systems. In A. M. Robserts, Yielding, G. \& Freeman, B. (eds), 1991, (Ed.), The Geometry of Normal Faults (Vol. 56, pp. 193-203): Geological Society Special Publication.

Webb, T. H., \& Anderson, H. (1998). Focal mechanisms of large earthquakes in the North Island of New Zealand: slip partitioning at an oblique active margin. Geophysical Journal International, 134(1), 40-86.

WesternGeco. (2012). Parihaka 3D PSTM Final Processing Report. Unpublished New Zealand Petroleum Report 4582, New Zealand Petroleum \& Minerals, Wellington.

Wizevich, M. C., Thrasher, G. P., Bussell, M. P., Wilson, G. J., \& Collen, J. D. (1992). Evidence for marine deposition in the Late Cretaceous Pakawau group, northwest Nelson. New Zealand Journal of Geology and Geophysics, 35(3), 363-369.

Woodward, D. J. (1997). Aeromagnetic survey, residual field removal, PEP 38716, Taranaki Basin. Unpublished New Zealand Petroleum Report 2296, New Zealand Petroleum \& Minerals, Wellington. 
Page intentionally left blank 


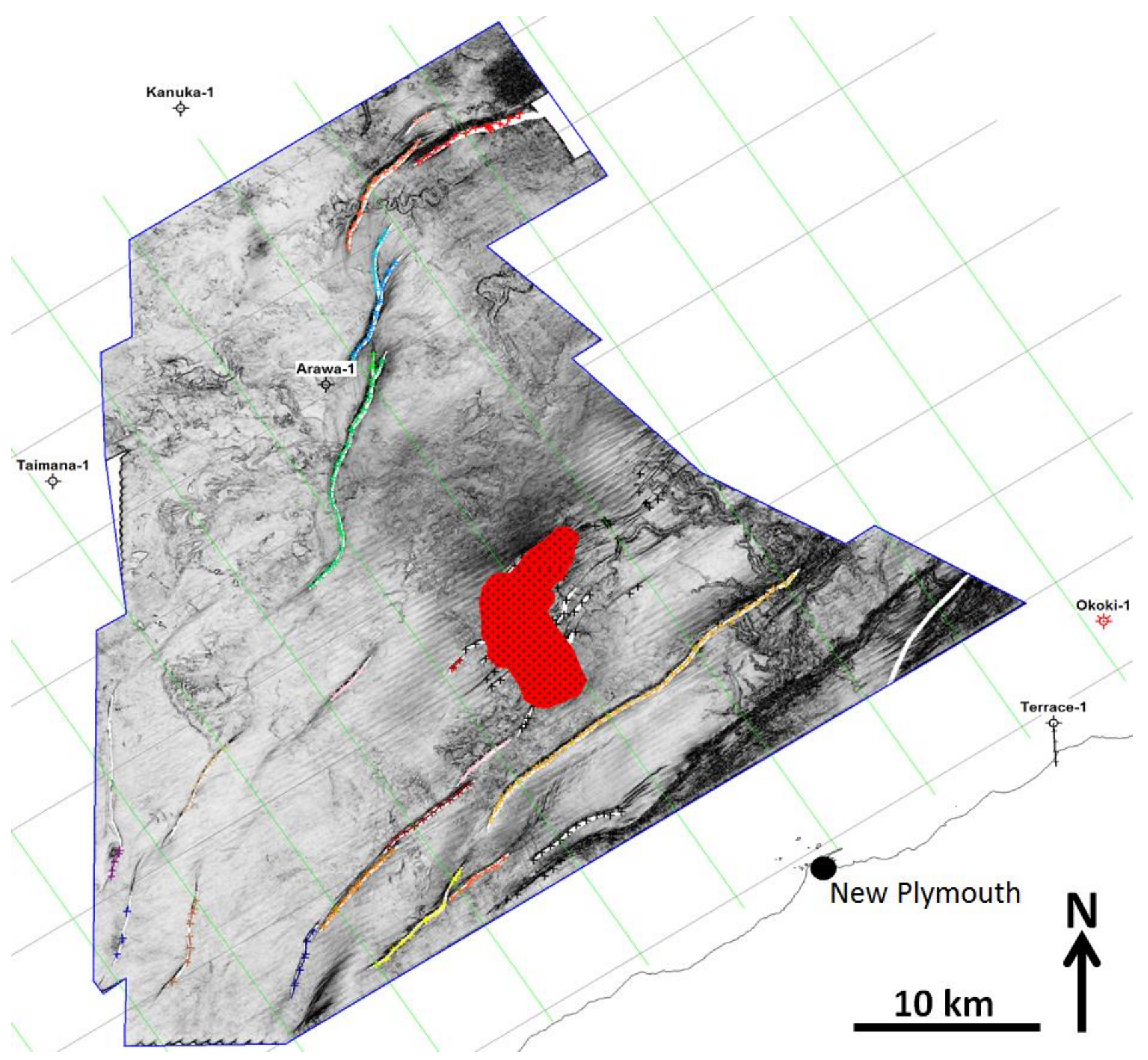

Appendix figure A.1a: Parihaka 3D seismic survey coherency cube time-slice $\mathbf{5 0}$ ms above the basal top-set horizon. Darker colours indicate areas with decreased coherence between adjacent traces. Fault positions are indicated by coloured lines with "+" symbols. The Southern Intrusive Complex is indicated by the red hatched polygon. 


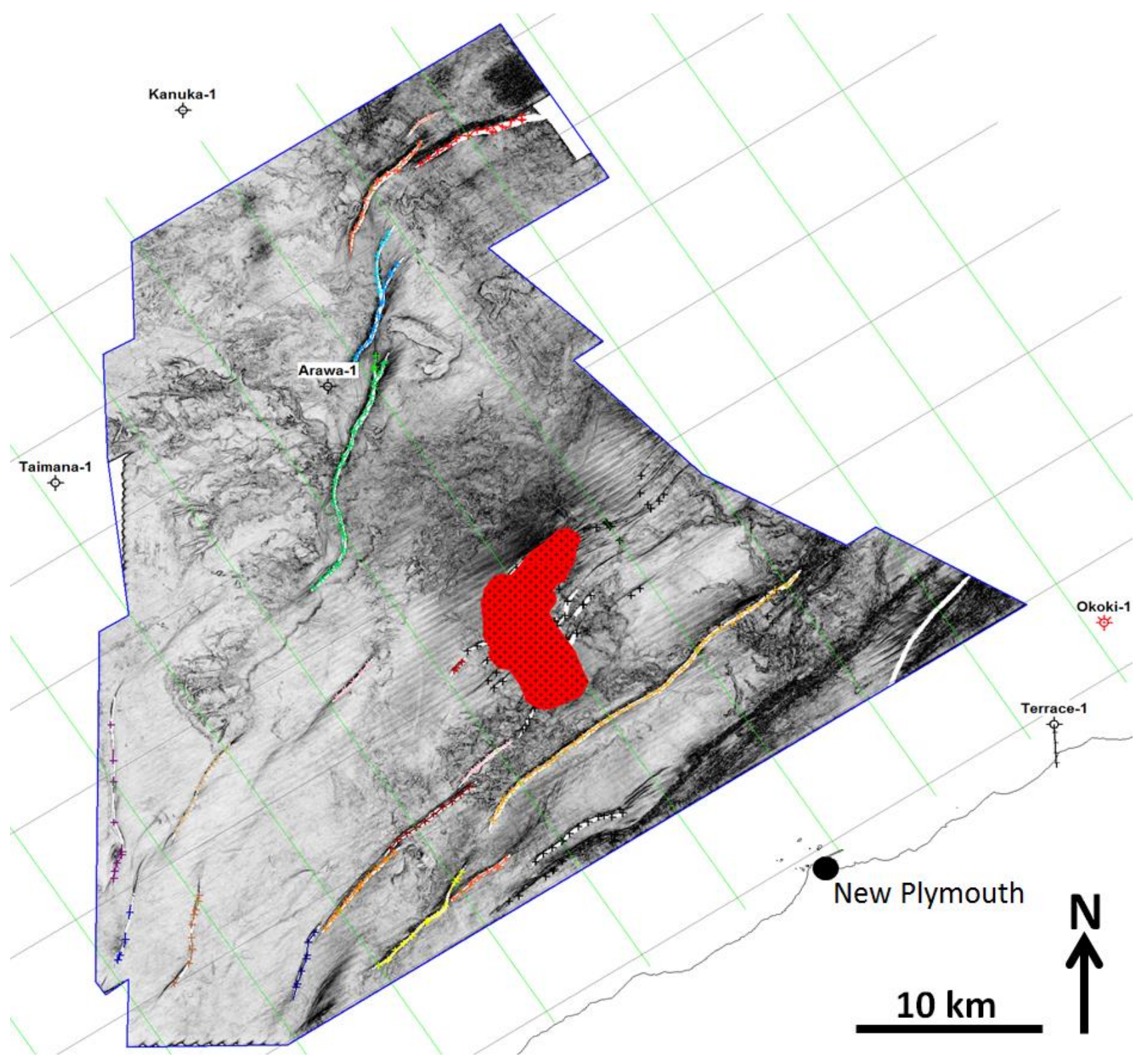

Appendix figure A.1b: Parihaka 3D seismic survey coherency cube time-slice $25 \mathrm{~ms}$ above the basal top-set horizon. Darker colours indicate areas with decreased coherence between adjacent traces. Fault positions are indicated by coloured lines with "+" symbols. The Southern Intrusive Complex is indicated by the red hatched polygon. 


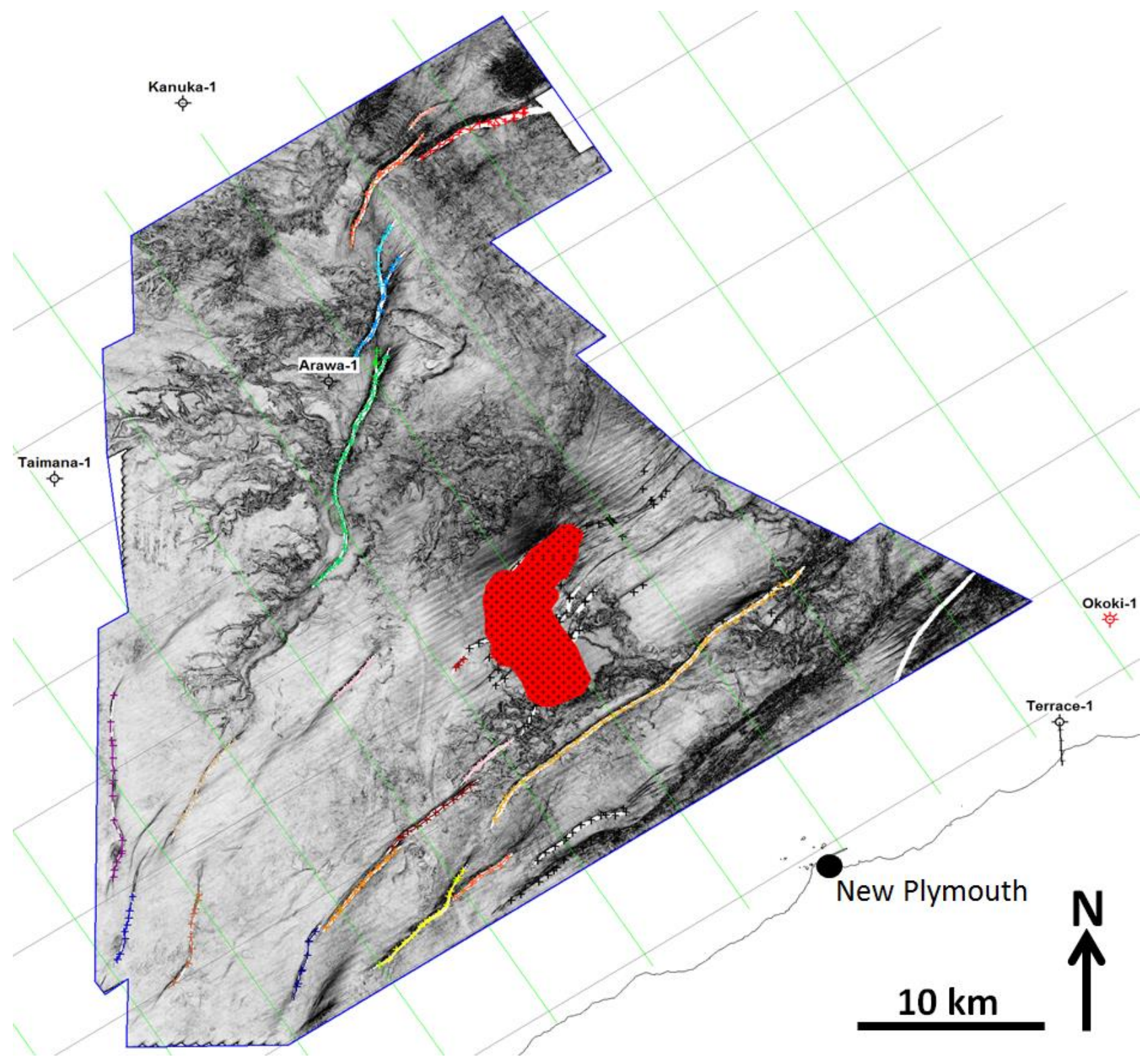

Appendix figure A.1c: Parihaka 3D seismic survey coherency cube time-slice level with the basal top-set horizon. Darker colours indicate areas with decreased coherence between adjacent traces. Fault positions are indicated by coloured lines with "+" symbols. The Southern Intrusive Complex is indicated by the red hatched polygon. 


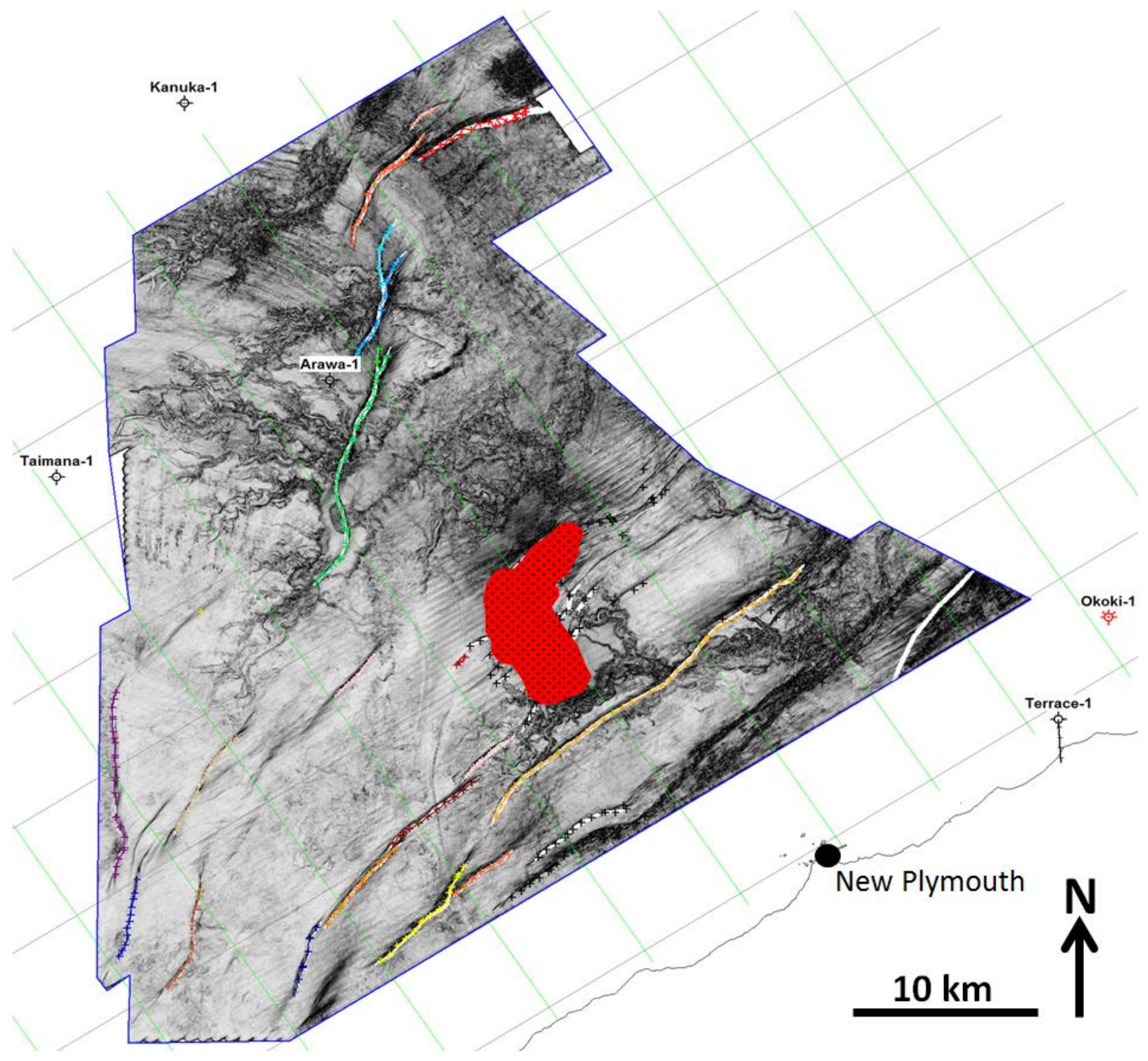

Appendix figure A.1d: Parihaka 3D seismic survey coherency cube time-slice $\mathbf{2 5} \mathrm{ms}$ below the basal top-set horizon. Darker colours indicate areas with decreased coherence between adjacent traces. Fault positions are indicated by coloured lines with "+" symbols. The Southern Intrusive Complex is indicated by the red hatched polygon. 


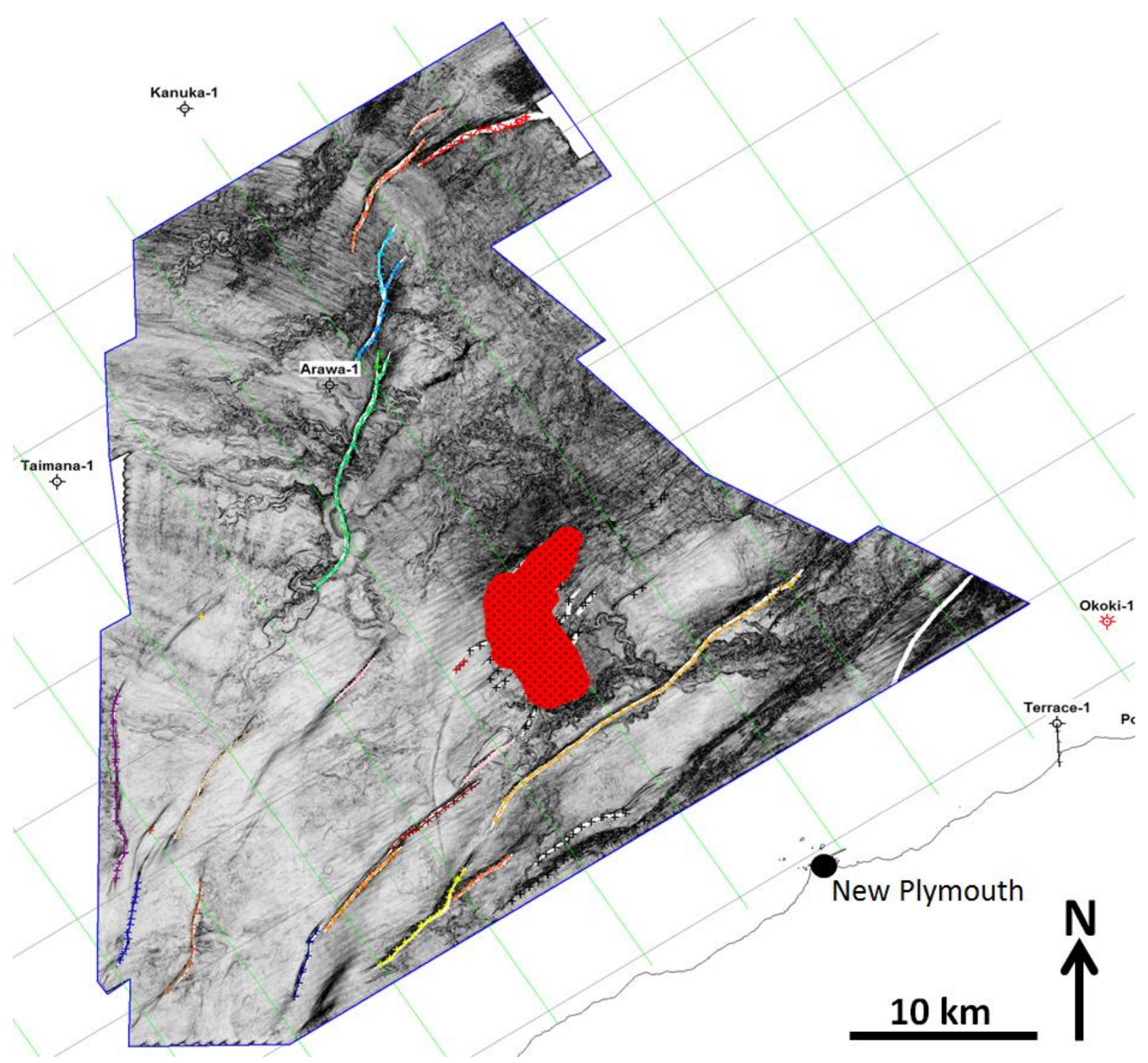

Appendix figure A.1e: Parihaka 3D seismic survey coherency cube time-slice $50 \mathrm{~ms}$ below the basal top-set horizon. Darker colours indicate areas with decreased coherence between adjacent traces. Fault positions are indicated by coloured lines with "+" symbols. The Southern Intrusive Complex is indicated by the red hatched polygon. 


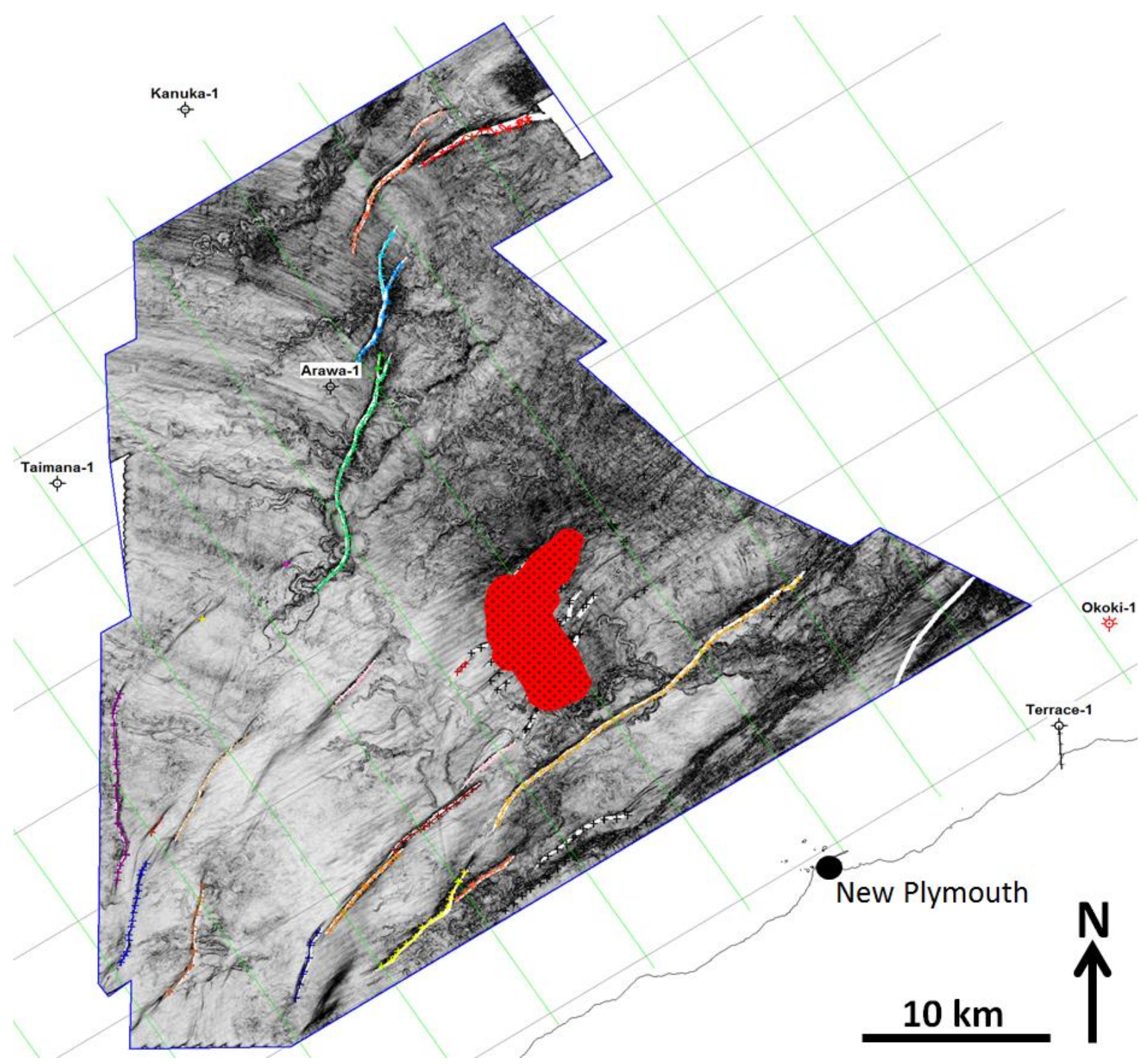

Appendix figure A.1f: Parihaka 3D seismic survey coherency cube time-slice $\mathbf{7 5}$ ms below the basal top-set horizon. Darker colours indicate areas with decreased coherence between adjacent traces. Fault positions are indicated by coloured lines with "+" symbols. The Southern Intrusive Complex is indicated by the red hatched polygon. 


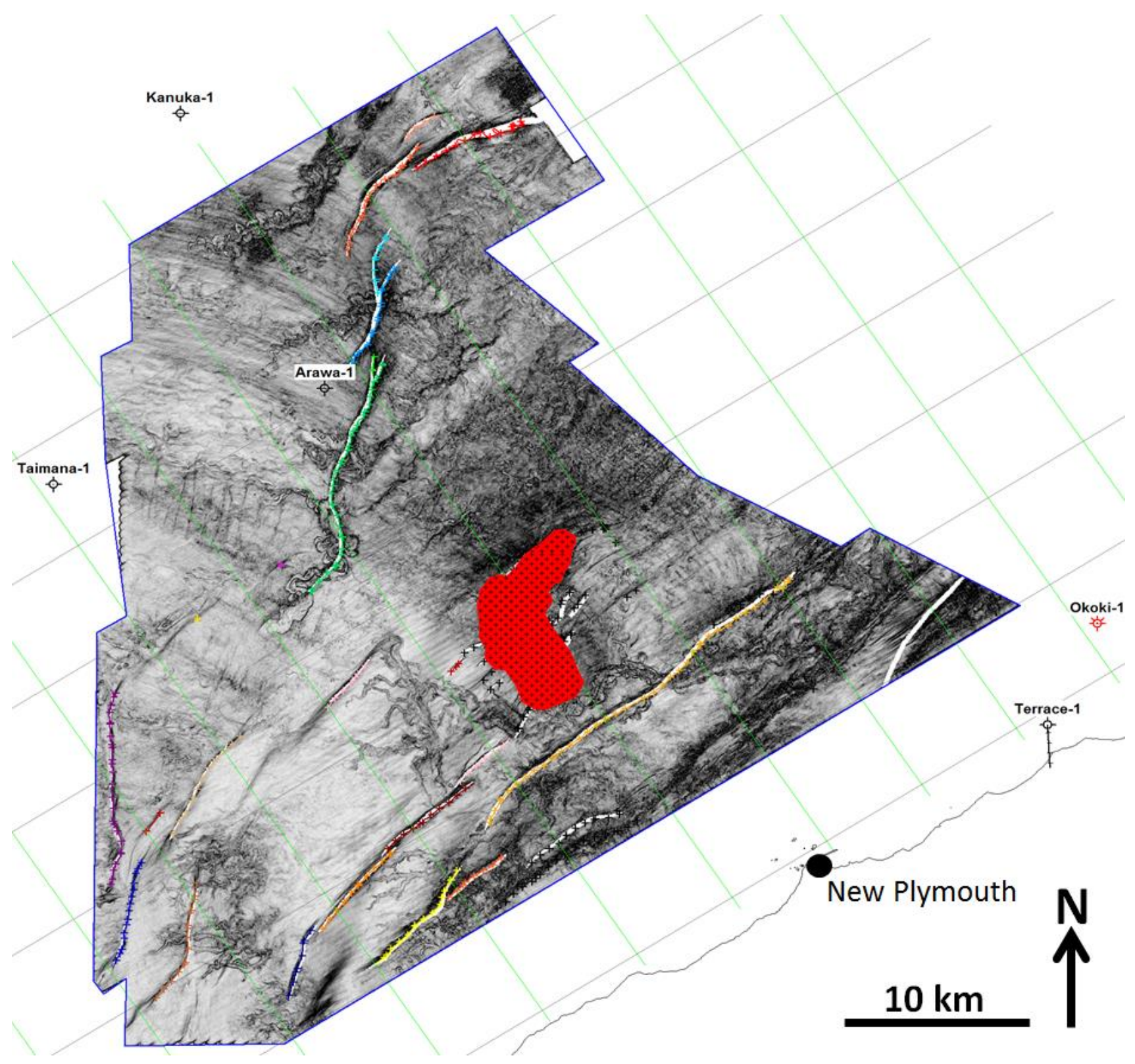

Appendix figure A.1g: Parihaka 3D seismic survey coherency cube time-slice $100 \mathrm{~ms}$ below the basal top-set horizon. Darker colours indicate areas with decreased coherence between adjacent traces. Fault positions are indicated by coloured lines with "+" symbols. The Southern Intrusive Complex is indicated by the red hatched polygon. 


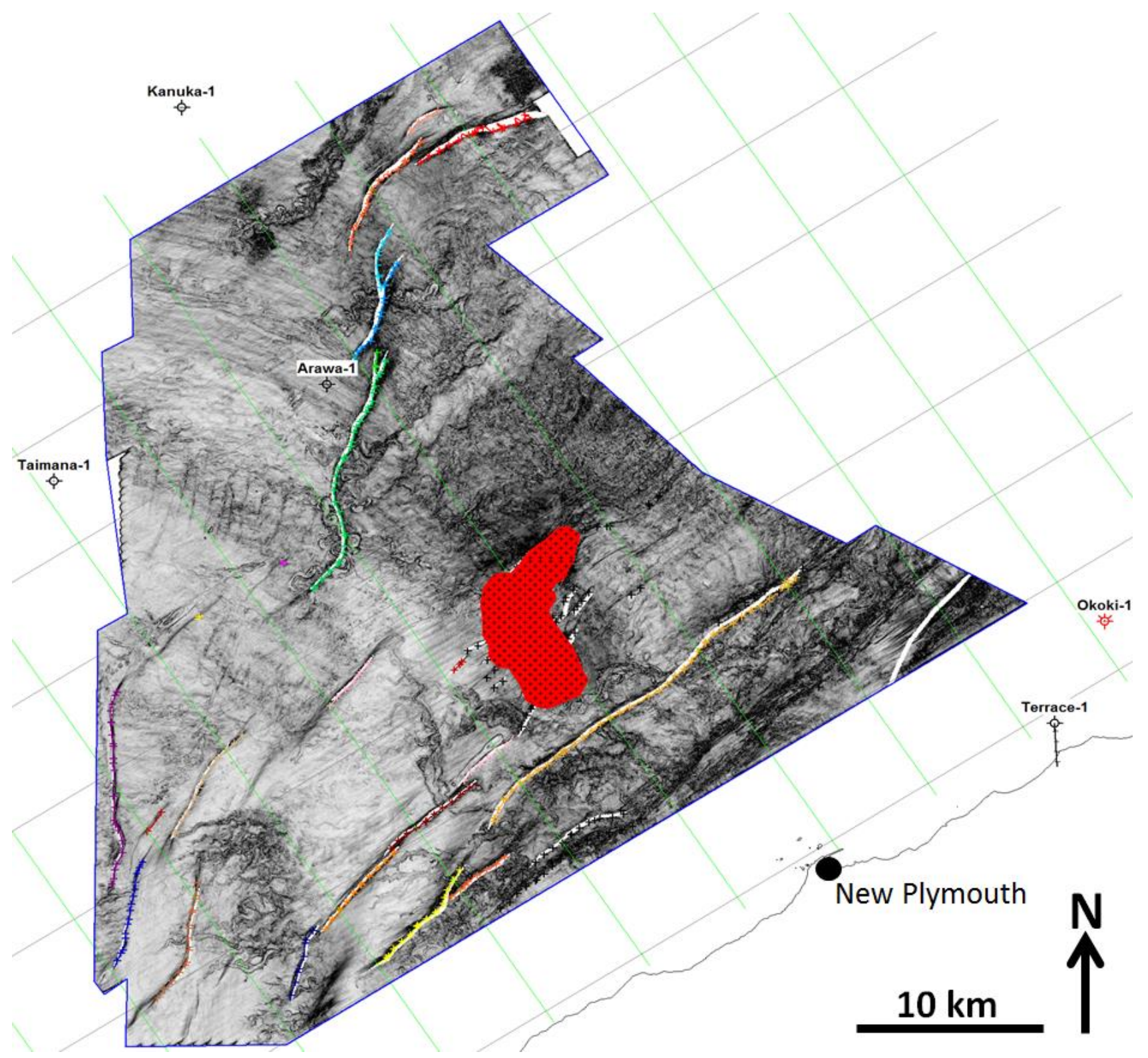

Appendix figure A.1h: Parihaka 3D seismic survey coherency cube time-slice $125 \mathrm{~ms}$ below the basal top-set horizon. Darker colours indicate areas with decreased coherence between adjacent traces. Fault positions are indicated by coloured lines with "+" symbols. The Southern Intrusive Complex is indicated by the red hatched polygon. 


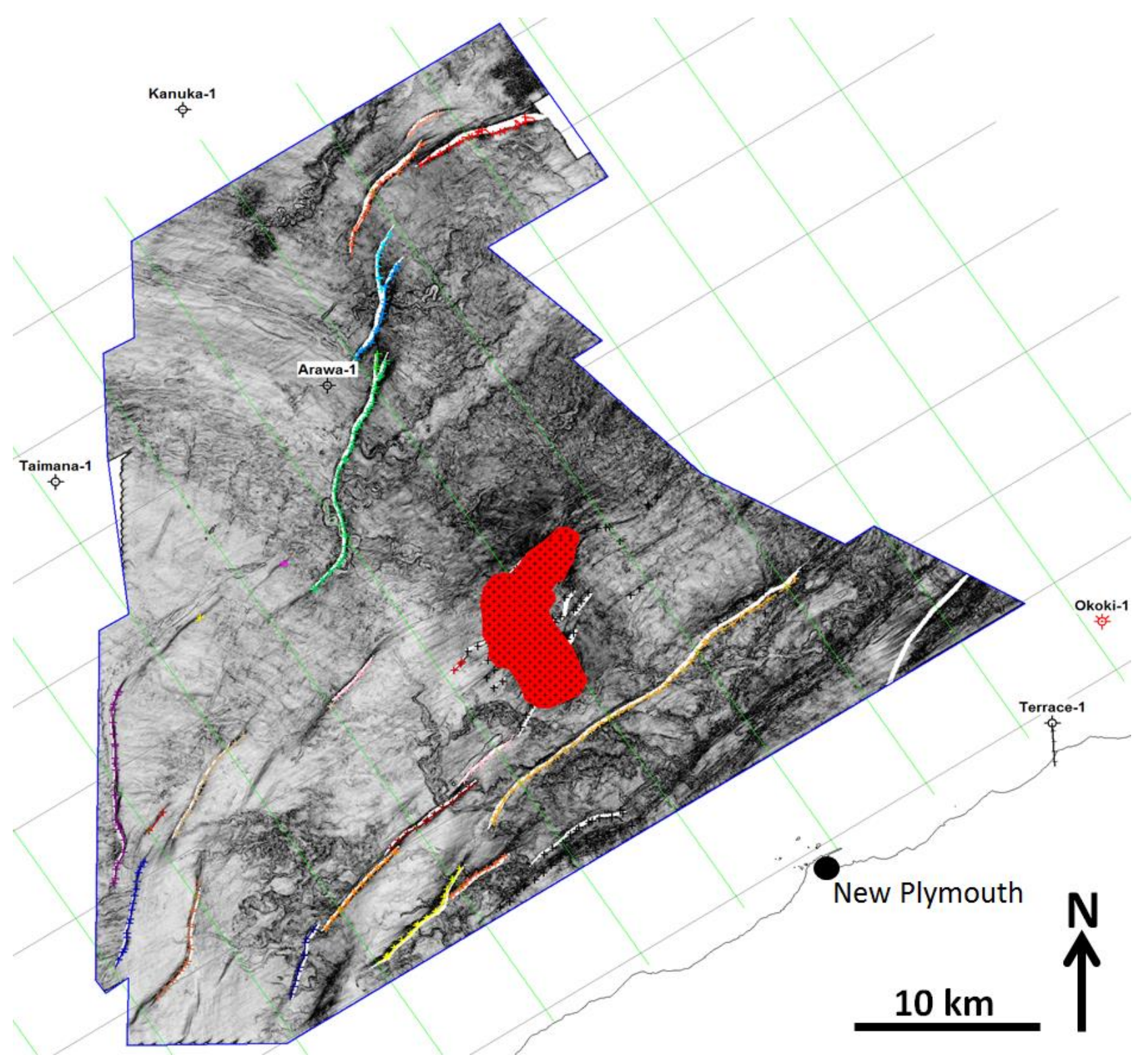

Appendix figure A.1i: Parihaka 3D seismic survey coherency cube time-slice $150 \mathrm{~ms}$ below the basal top-set horizon. Darker colours indicate areas with decreased coherence between adjacent traces. Fault positions are indicated by coloured lines with "+" symbols. The Southern Intrusive Complex is indicated by the red hatched polygon. 


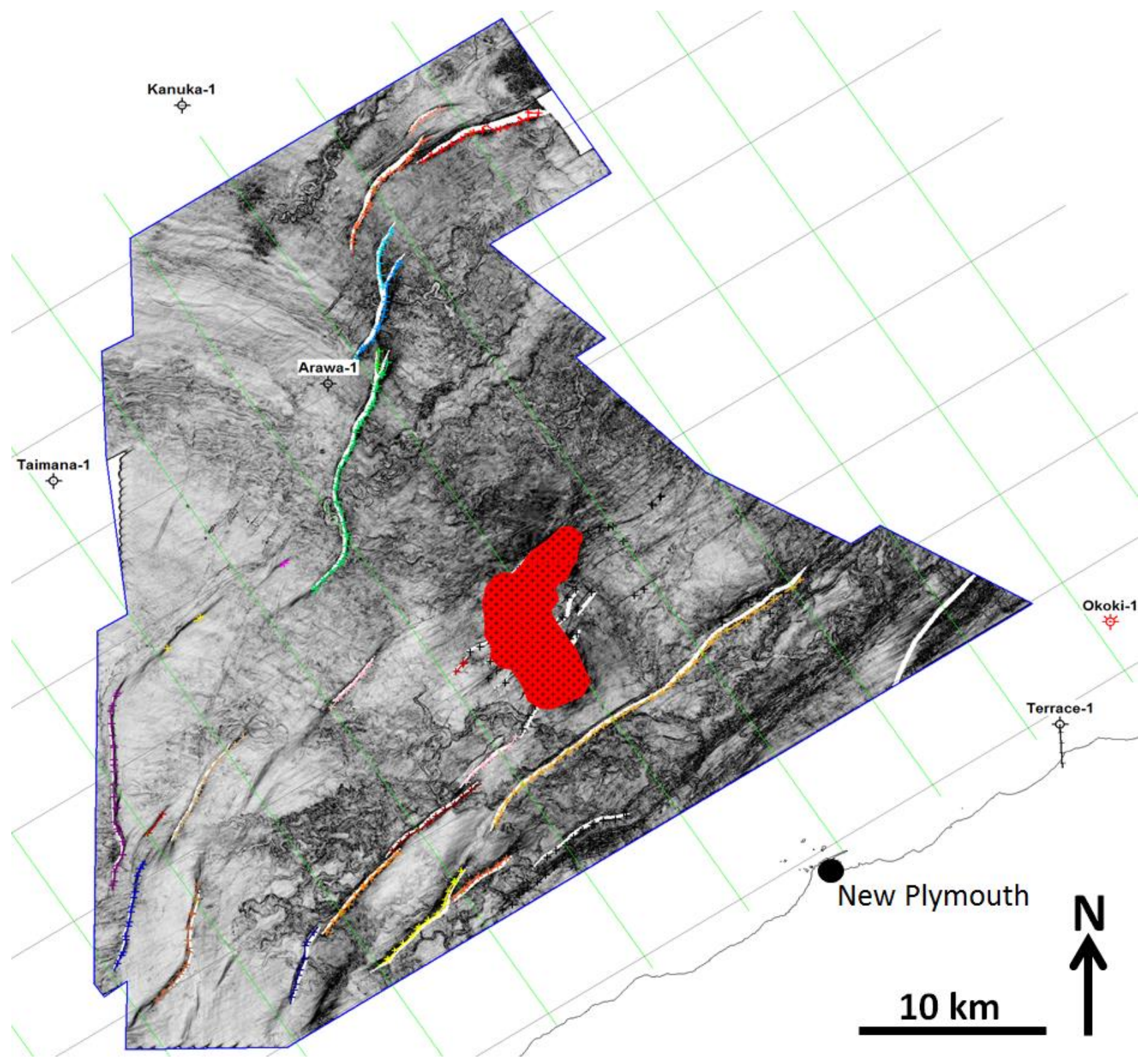

Appendix figure A.1j: Parihaka 3D seismic survey coherency cube time-slice $\mathbf{1 7 5} \mathrm{ms}$ below the basal top-set horizon. Darker colours indicate areas with decreased coherence between adjacent traces. Fault positions are indicated by coloured lines with "+" symbols. The Southern Intrusive Complex is indicated by the red hatched polygon. 


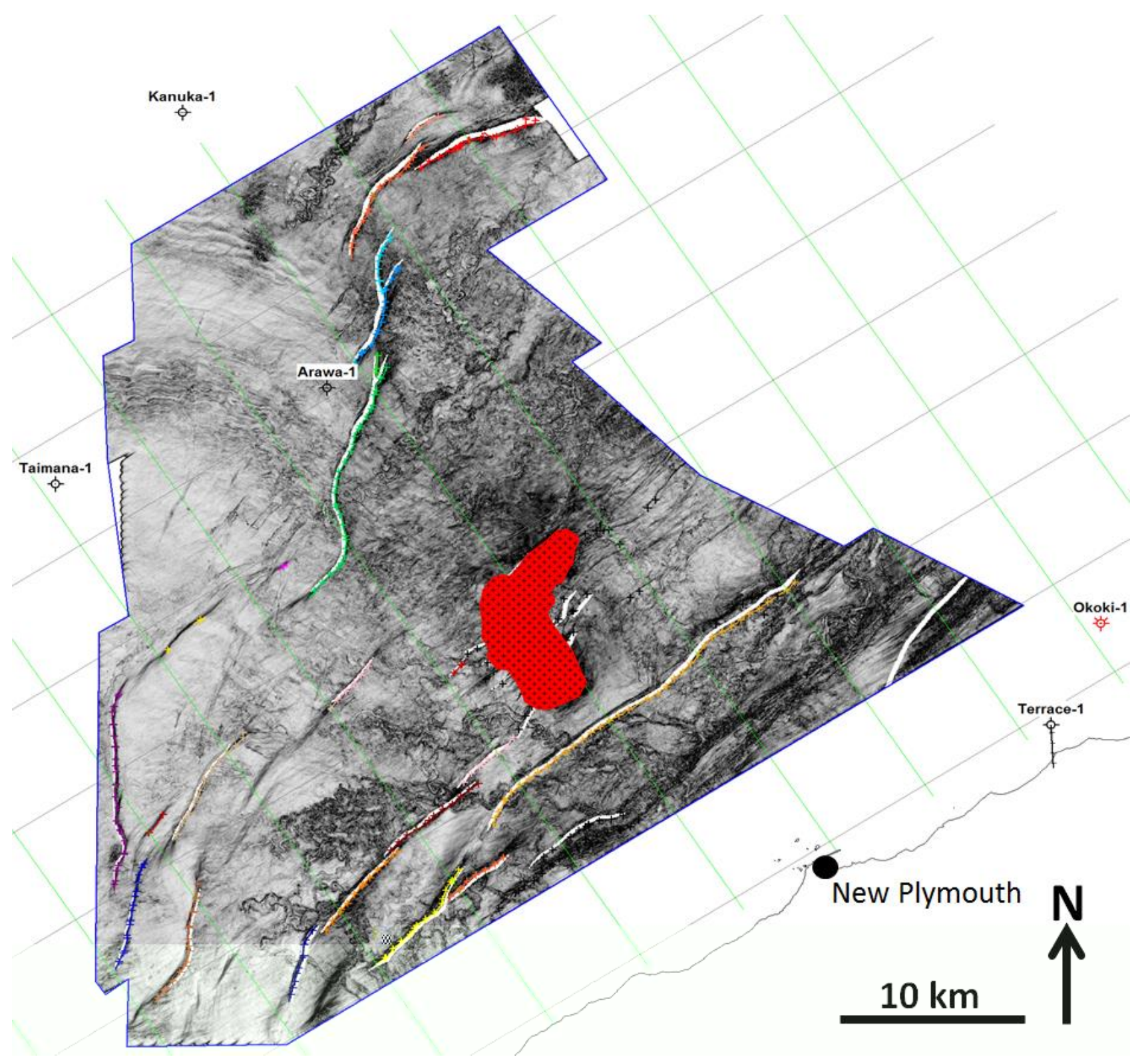

Appendix figure A.1k: Parihaka 3D seismic survey coherency cube time-slice $\mathbf{2 0 0}$ ms below the basal top-set horizon. Darker colours indicate areas with decreased coherence between adjacent traces. Fault positions are indicated by coloured lines with "+" symbols. The Southern Intrusive Complex is indicated by the red hatched polygon. 


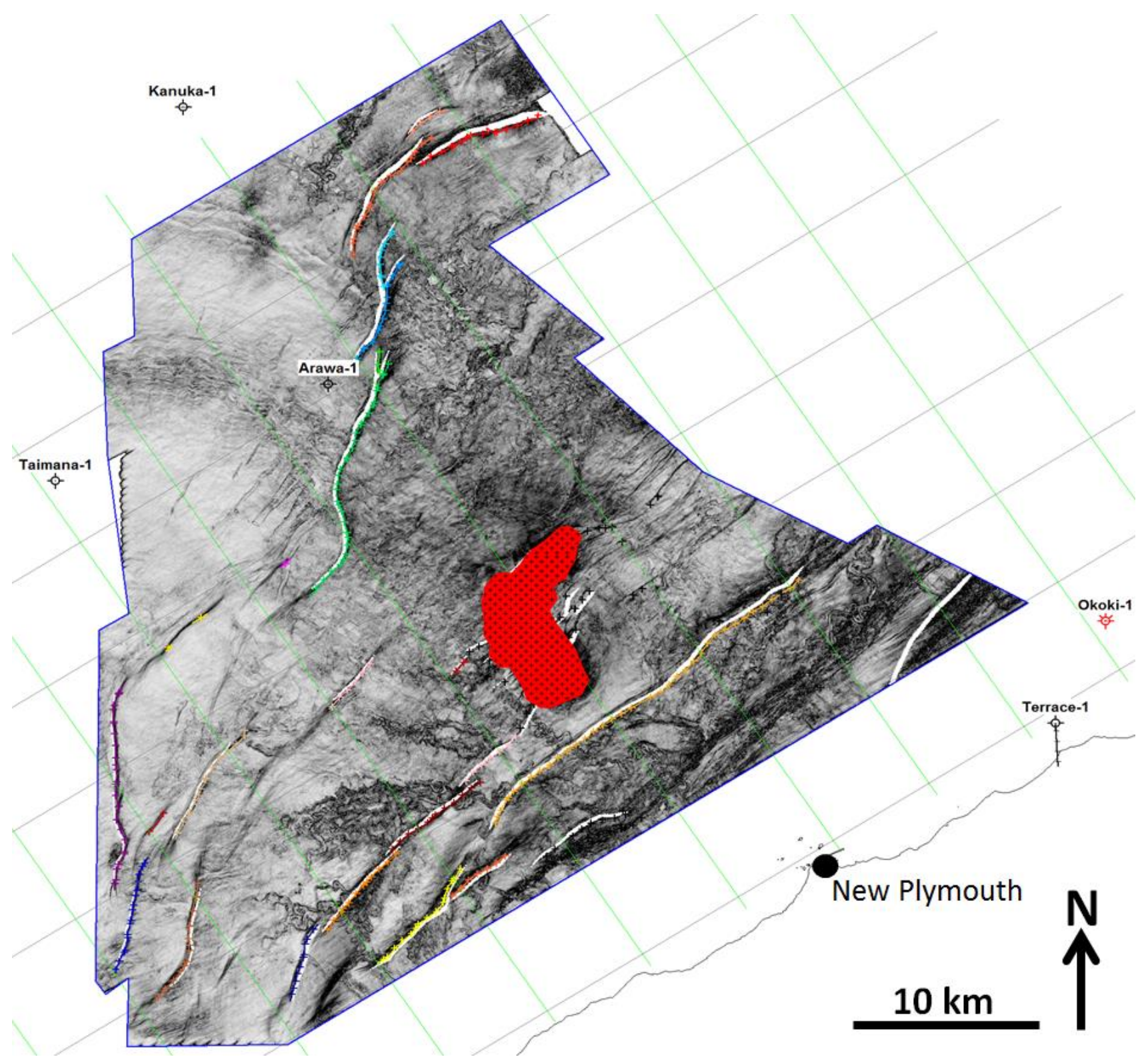

Appendix figure A.1l: Parihaka 3D seismic survey coherency cube time-slice $\mathbf{2 2 5}$ ms below the basal top-set horizon. Darker colours indicate areas with decreased coherence between adjacent traces. Fault positions are indicated by coloured lines with "+" symbols. The Southern Intrusive Complex is indicated by the red hatched polygon. 


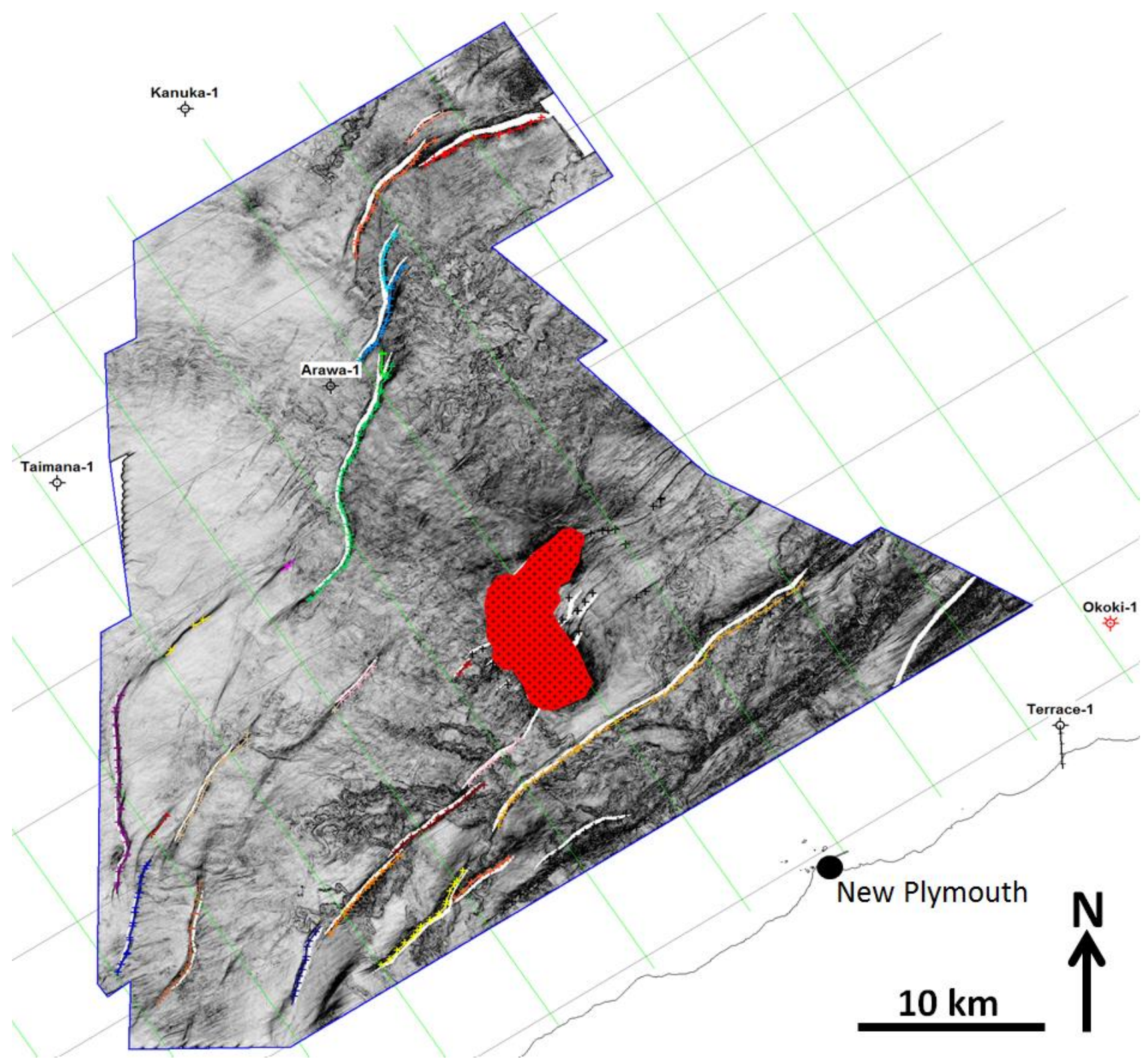

Appendix figure A.1m: Parihaka 3D seismic survey coherency cube time-slice $\mathbf{2 5 0}$ ms below the basal top-set horizon. Darker colours indicate areas with decreased coherence between adjacent traces. Fault positions are indicated by coloured lines with "+" symbols. The Southern Intrusive Complex is indicated by the red hatched polygon. 
Appendix B: Seismic Cross-Sections

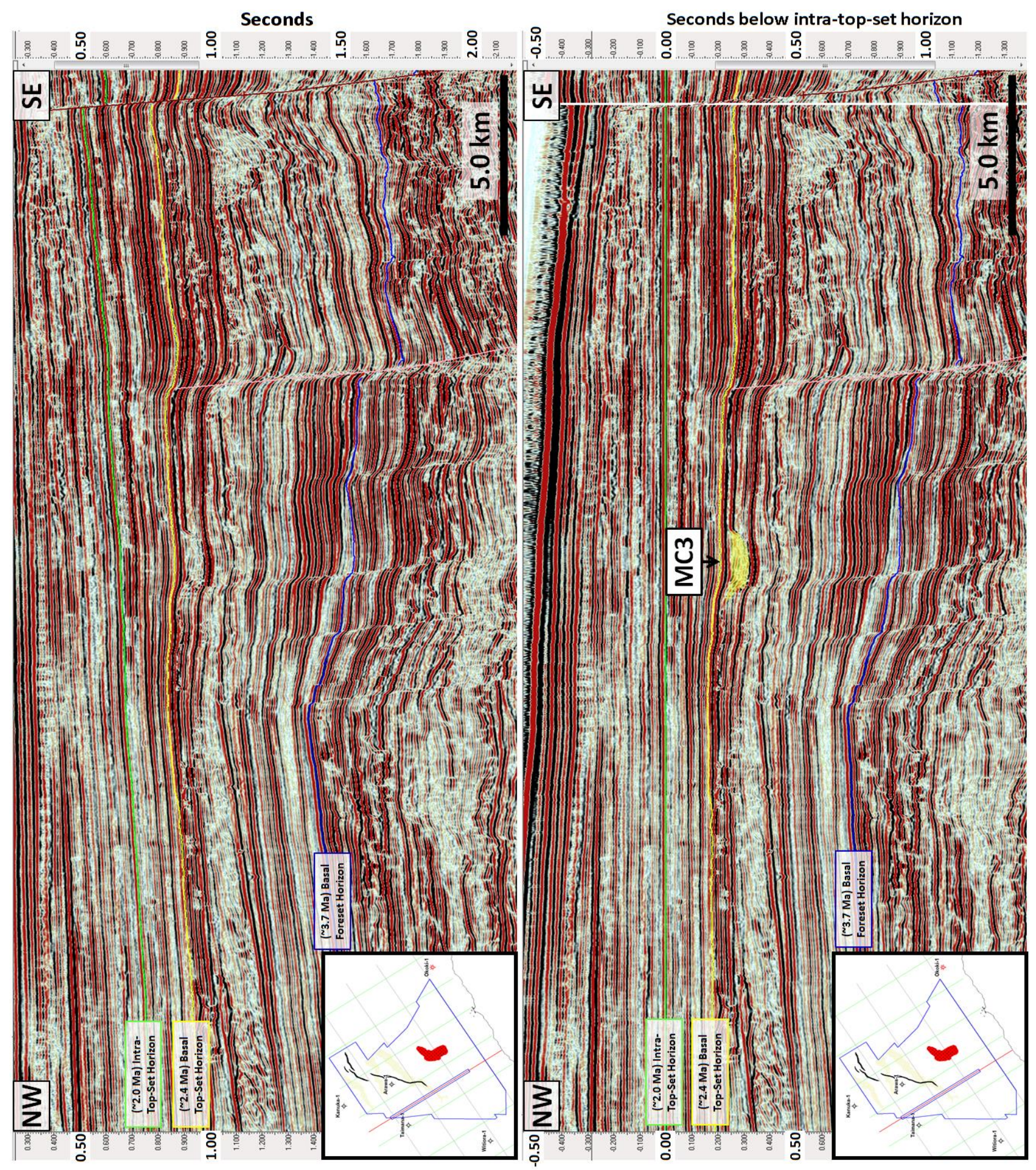

Appendix figure B.1a: Seismic cross-section of crossline 3500 of the Parihaka 3D seismic survey. The upper panel is a seismic section with horizons and major faults annotated only. The lower panel is a seismic section flattened on the intra-top-set horizon and annotated with the position of mega-channel 3 (MC3) (highlighted by the transparent yellow polygon). Horizons are labelled with coloured boxes. Major faults are indicated by coloured lines with "+" symbols. The position of crossline $\mathbf{3 5 0 0}$ within the study area is shown in the inset panels (visible portion = blue rectangle). Seismic polarity convention is red for negative and black for positive. 


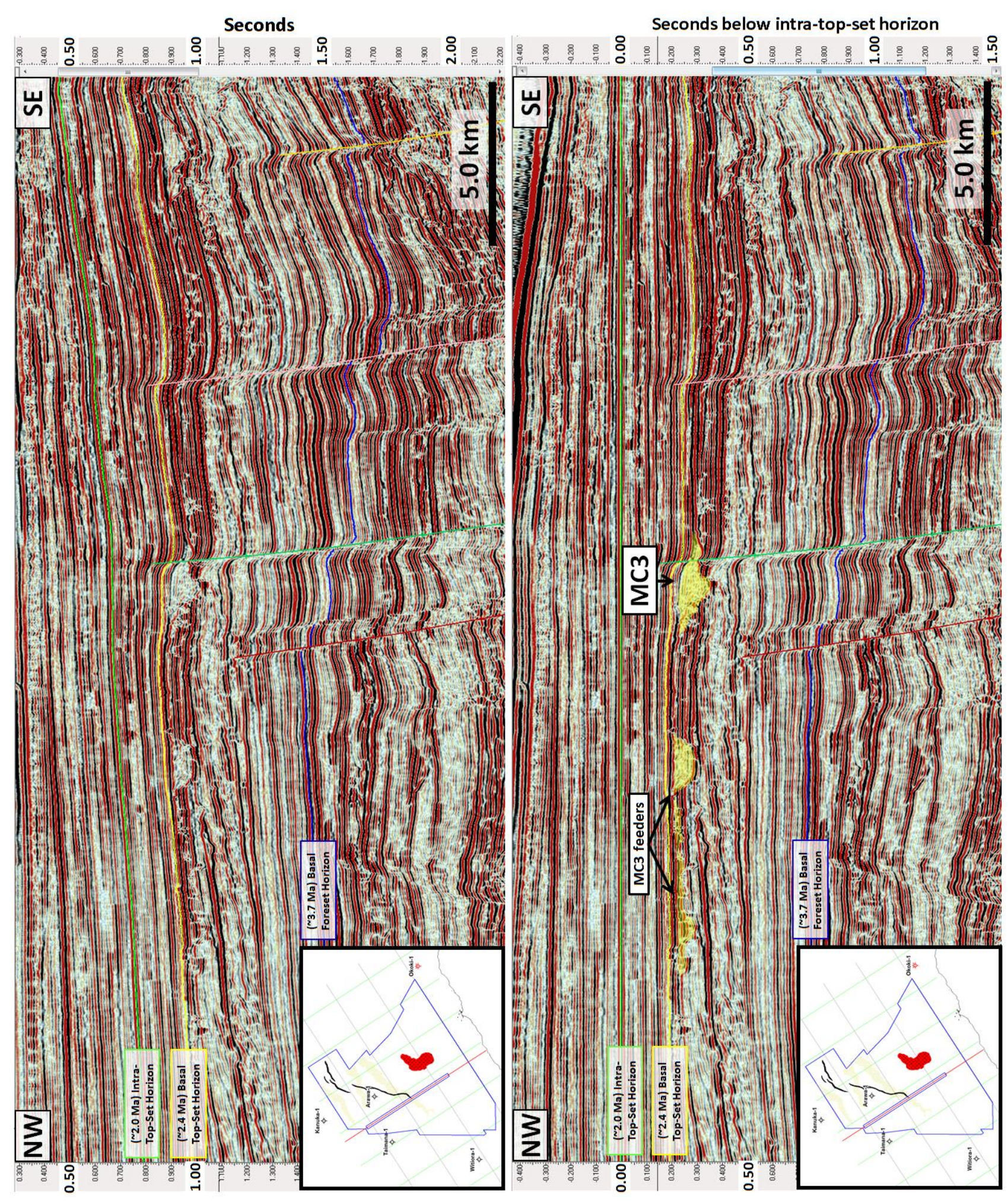

Appendix figure B.1b: Seismic cross-section of crossline $\mathbf{3 7 5 0}$ of the Parihaka 3D seismic survey. The upper panel is a seismic section with horizons and major faults annotated only. The lower panel is a seismic section flattened on the intra-top-set horizon and annotated with the position of mega-channel 3 (MC3) and its feeder channels (highlighted by the transparent yellow polygons). Horizons are labelled with coloured boxes. Major faults are indicated by coloured lines with "+" symbols. The position of crossline $\mathbf{3 7 5 0}$ within the study area is shown in the inset panels (visible portion = blue rectangle). Seismic polarity convention is red for negative and black for positive. 


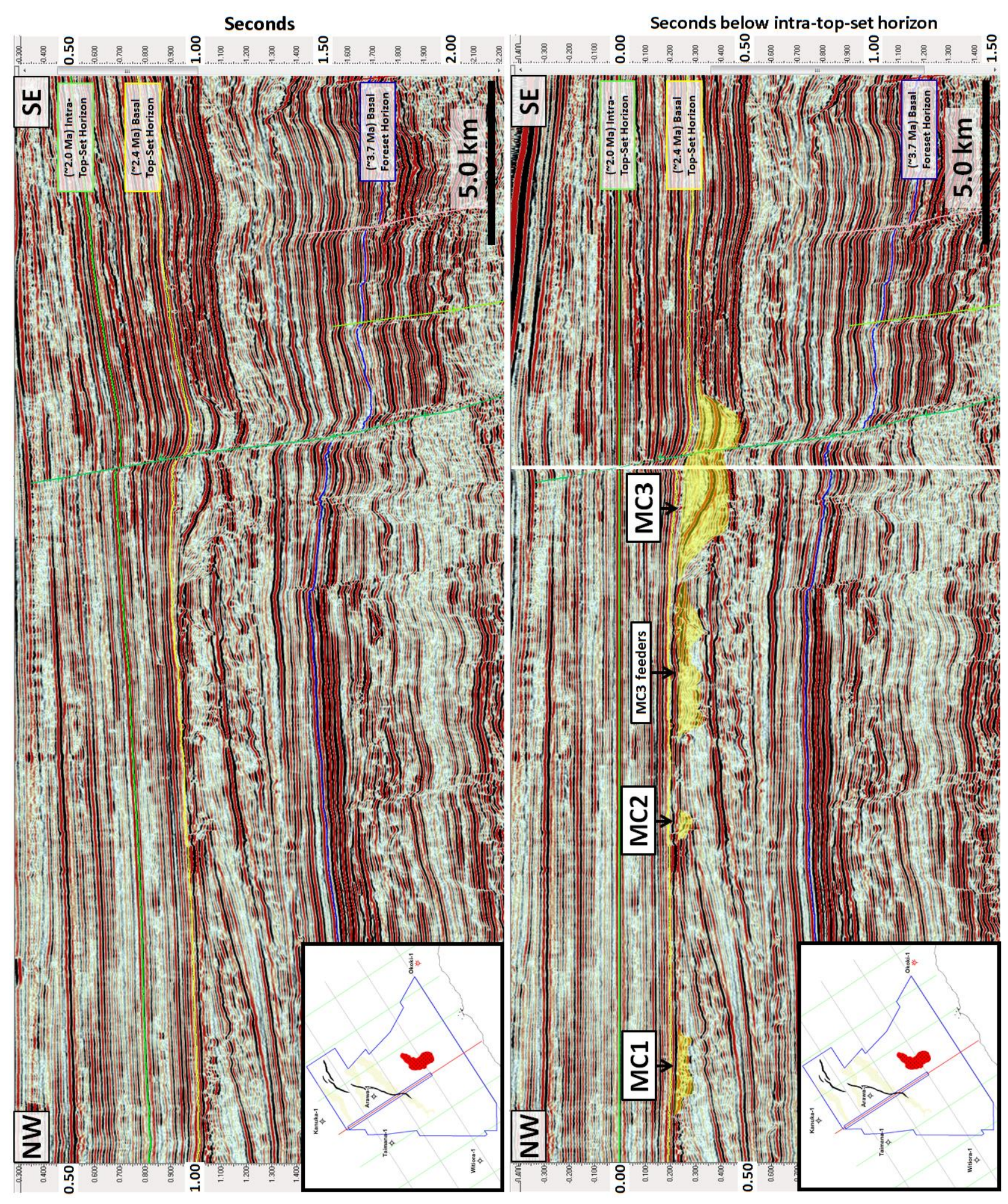

Appendix figure B.1c: Seismic cross-section of crossline 4000 of the Parihaka 3D seismic survey. The upper panel is a seismic section with horizons and major faults annotated only. The lower panel is a seismic section flattened on the intra-top-set horizon and annotated with the position of the mega-channels (MC1/2/3) (highlighted by the transparent yellow polygons) and MC3 feeder channels. Horizons are labelled with coloured boxes. Major faults are indicated by coloured lines with "+" symbols. The position of crossline $\mathbf{4 0 0 0}$ within the study area is shown in the inset panels (visible portion = blue rectangle). Seismic polarity convention is red for negative and black for positive. 

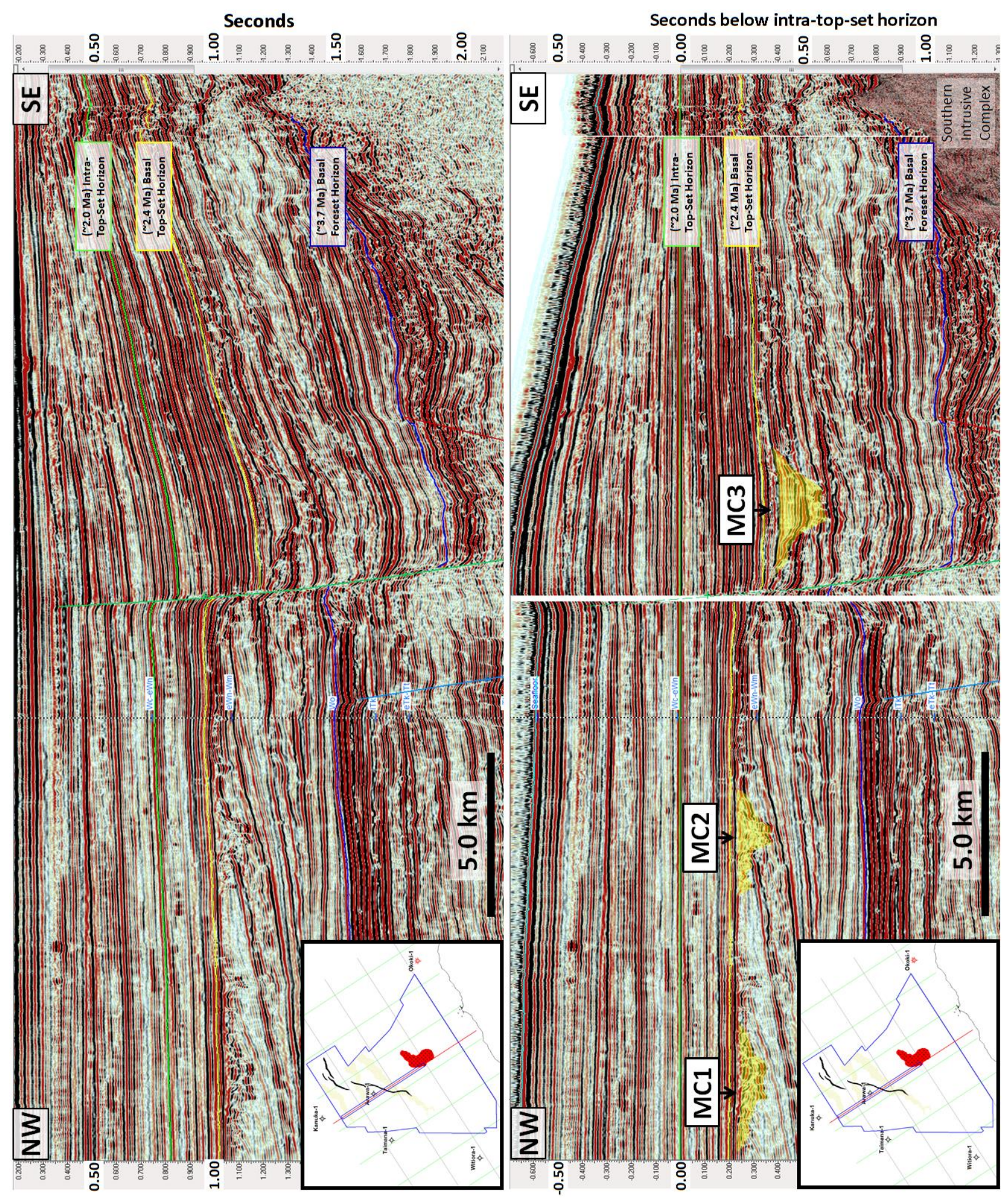

Appendix figure B.1d: Seismic cross-section of crossline $\mathbf{4 2 5 0}$ of the Parihaka 3D seismic survey. The upper panel is a seismic section with horizons and major faults annotated only. The lower panel is a seismic section flattened on the intra-top-set horizon and annotated with the position of the mega-channels ( $\mathrm{MC1} / 2 / 3$ ) (highlighted by the transparent yellow polygons). Horizons are labelled with coloured boxes. Major faults are indicated by coloured lines with "+" symbols. The position of crossline $\mathbf{4 2 5 0}$ within the study area is shown in the inset panels (visible portion = blue rectangle). Seismic polarity convention is red for negative and black for positive. 


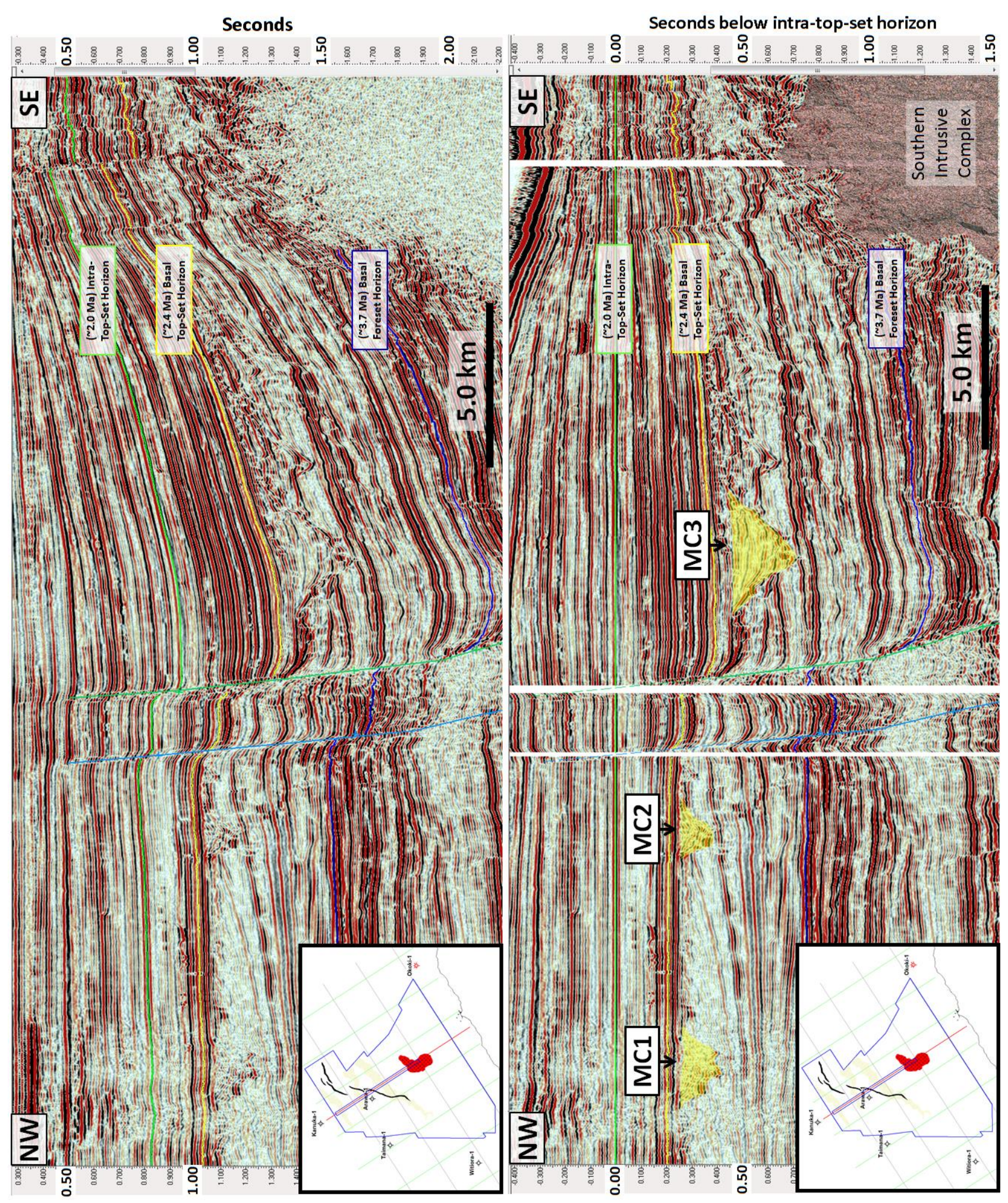

Appendix figure B.1e: Seismic cross-section of crossline 4500 of the Parihaka 3D seismic survey. The upper panel is a seismic section with horizons and major faults annotated only. The lower panel is a seismic section flattened on the intra-top-set horizon and annotated with the position of the mega-channels (MC1/2/3) (highlighted by the transparent yellow polygons). Horizons are labelled with coloured boxes. Major faults are indicated by coloured lines with "+" symbols. The position of crossline $\mathbf{4 5 0 0}$ within the study area is shown in the inset panels (visible portion = blue rectangle). Seismic polarity convention is red for negative and black for positive. 


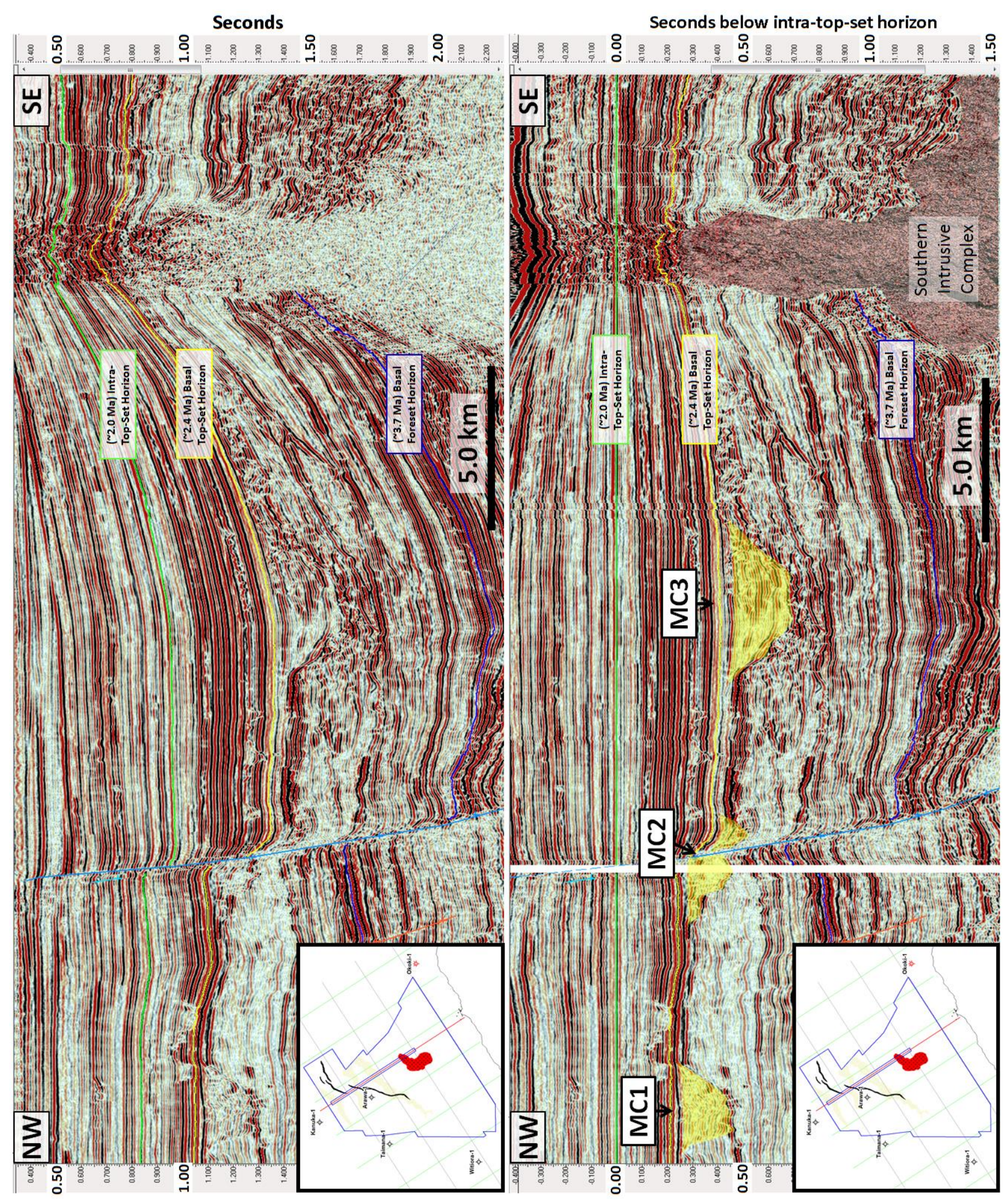

Appendix figure B.1f: Seismic cross-section of crossline $\mathbf{4 7 5 0}$ of the Parihaka 3D seismic survey. The upper panel is a seismic section with horizons and major faults annotated only. The lower panel is a seismic section flattened on the intra-top-set horizon and annotated with the position of the mega-channels ( $\mathrm{MC1} / 2 / 3$ ) (highlighted by the transparent yellow polygons). Horizons are labelled with coloured boxes. Major faults are indicated by coloured lines with "+" symbols. The position of crossline $\mathbf{4 7 5 0}$ within the study area is shown in the inset panels (visible portion = blue rectangle). Seismic polarity convention is red for negative and black for positive. 


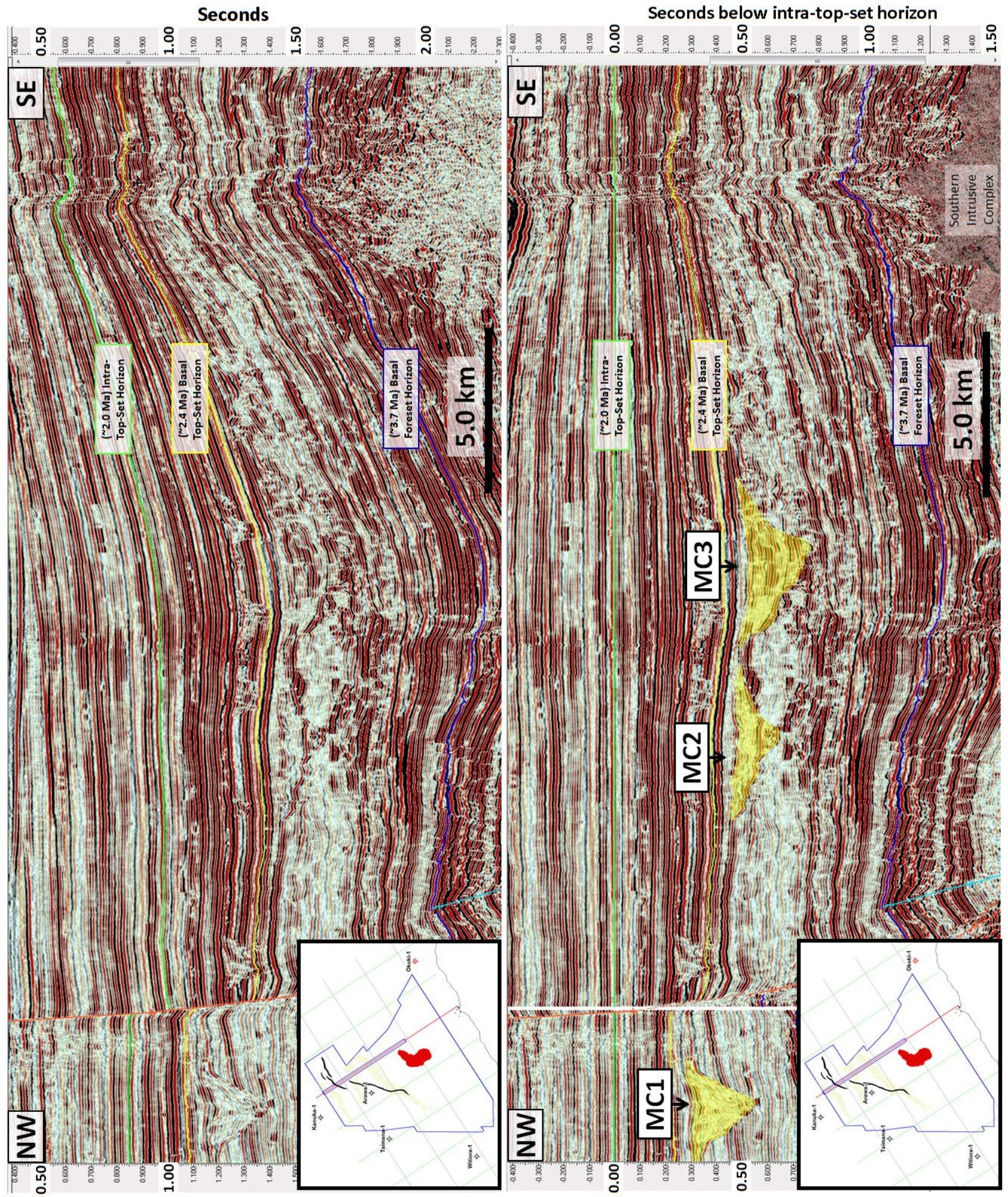

Appendix figure B.1g: Seismic cross-section of crossline 5000 of the Parihaka 3D seismic survey. The upper panel is a seismic section with horizons and major faults annotated only. The lower panel is a seismic section flattened on the intra-top-set horizon and annotated with the position of the mega-channels ( $\mathrm{MC1} / 2 / 3$ ) (highlighted by the transparent yellow polygons). Horizons are labelled with coloured boxes. Major faults are indicated by coloured lines with "+" symbols. The position of crossline $\mathbf{5 0 0 0}$ within the study area is shown in the inset panels (visible portion = blue rectangle). Seismic polarity convention is red for negative and black for positive. 

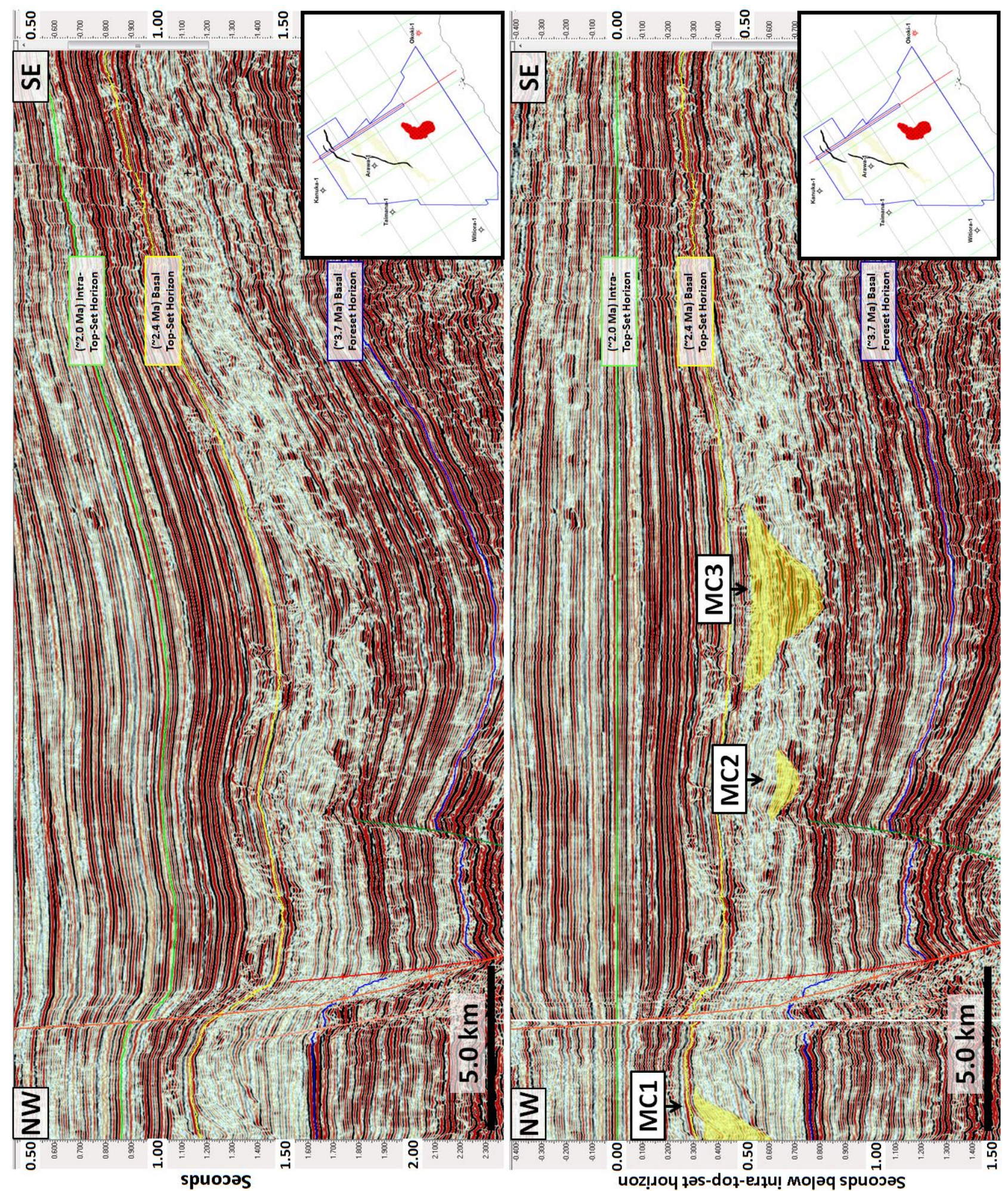

Appendix figure B.1h: Seismic cross-section of crossline 5250 of the Parihaka 3D seismic survey. The upper panel is a seismic section with horizons and major faults annotated only. The lower panel is a seismic section flattened on the intra-top-set horizon and annotated with the position of the mega-channels ( $\mathrm{MC1} / 2 / 3$ ) (highlighted by the transparent yellow polygons). Horizons are labelled with coloured boxes. Major faults are indicated by coloured lines with "+" symbols. The position of crossline $\mathbf{5 2 5 0}$ within the study area is shown in the inset panels (visible portion = blue rectangle). Seismic polarity convention is red for negative and black for positive. 

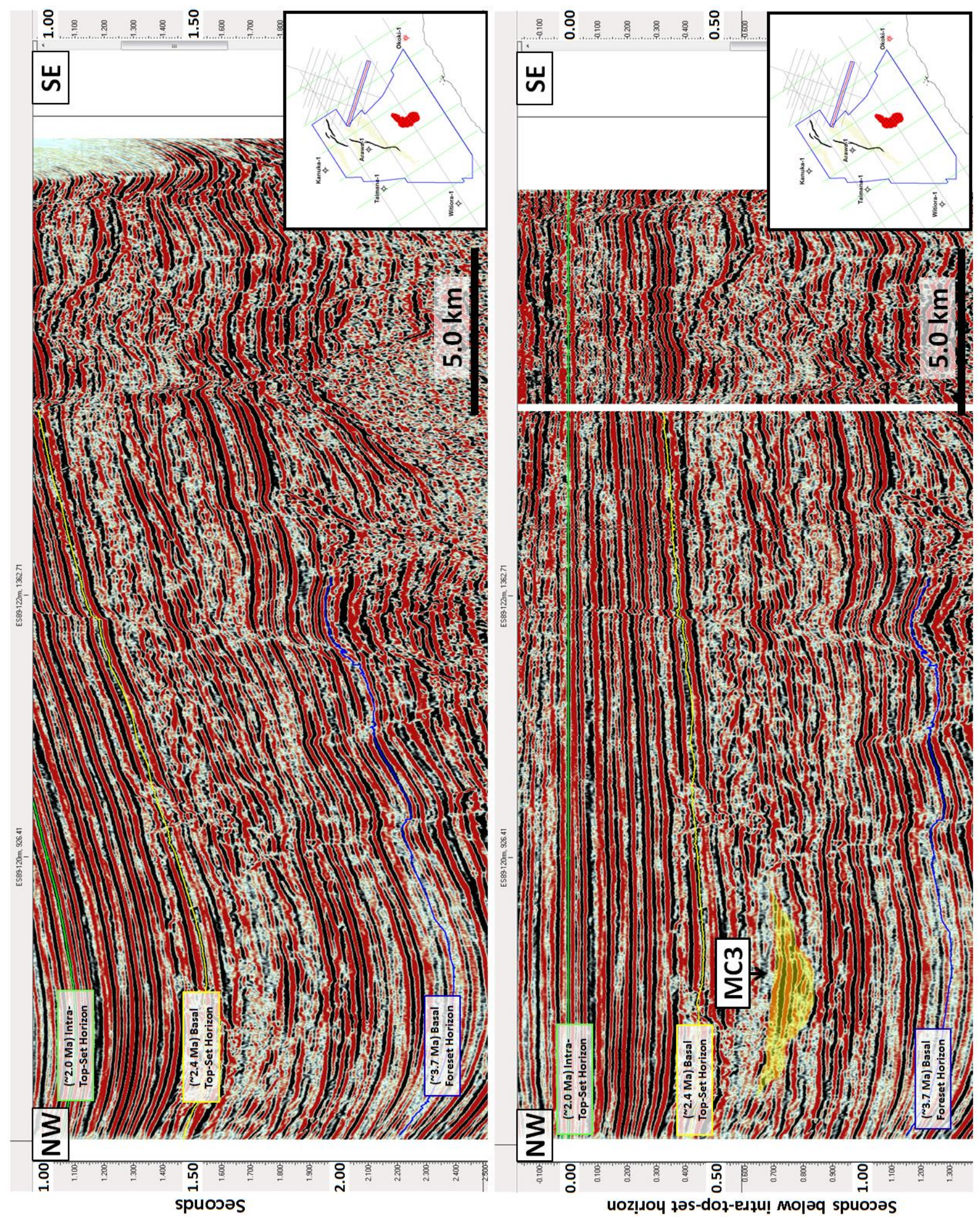

Appendix figure B.1i: Seismic cross-section of line ES89-118 of the ES89 2D seismic survey. The upper panel is a seismic section with horizons and annotated only. The lower panel is a seismic section flattened on the intra-top-set horizon and annotated with the position of the megachannel 3 (MC3) (highlighted by the transparent yellow polygon). Horizons are labelled with coloured boxes. The position of ES89-118 within the study area is shown in the inset panels (visible portion = blue rectangle). Seismic polarity convention is red for negative and black for positive. 

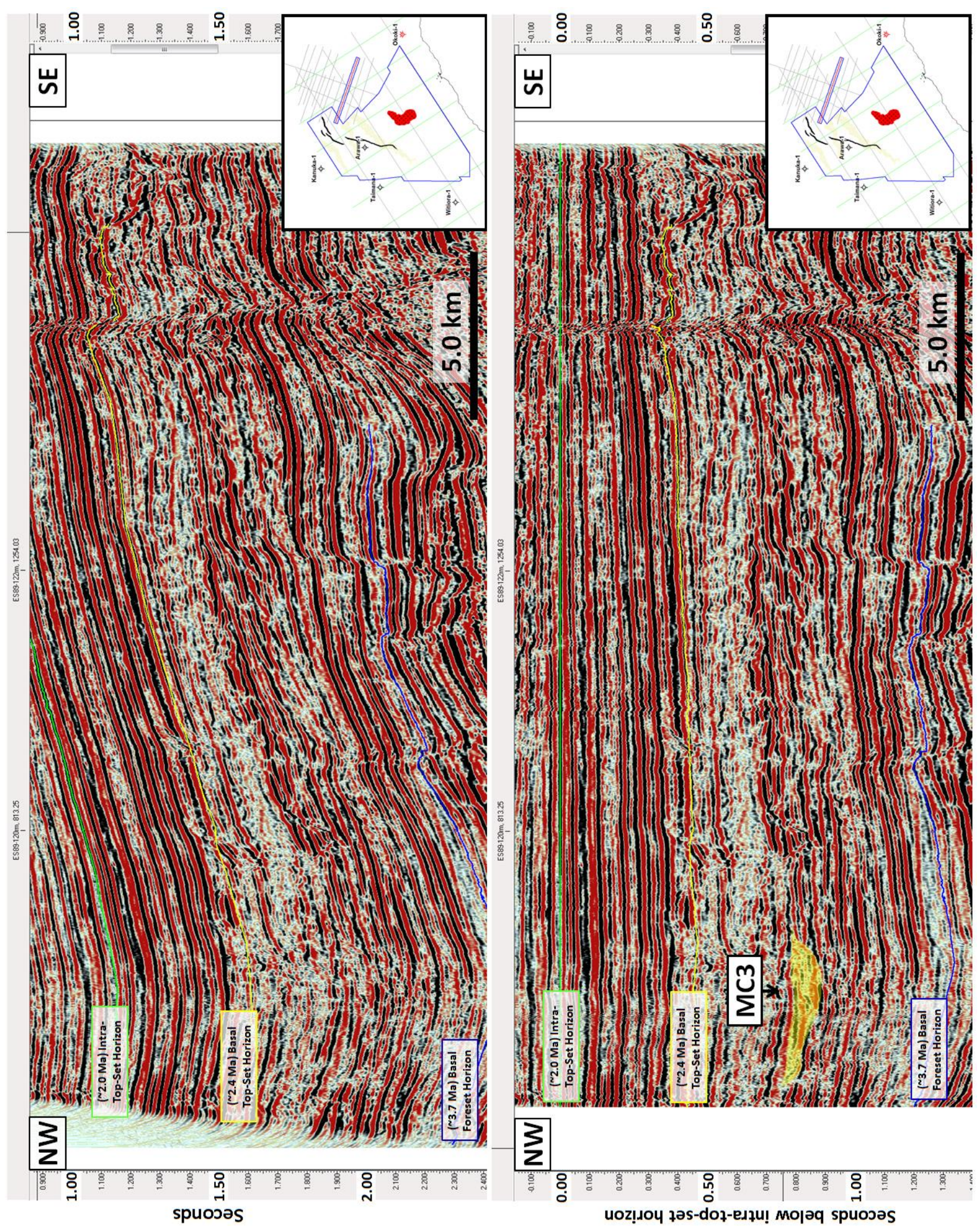

Appendix figure B.1j: Seismic cross-section of line ES89-116 of the ES89 2D seismic survey. The upper panel is a seismic section with horizons and annotated only. The lower panel is a seismic section flattened on the intra-top-set horizon and annotated with the position of the megachannel 3 (MC3) (highlighted by the transparent yellow polygon). Horizons are labelled with coloured boxes. The position of ES89-116 within the study area is shown in the inset panels (visible portion = blue rectangle). Seismic polarity convention is red for negative and black for positive. 

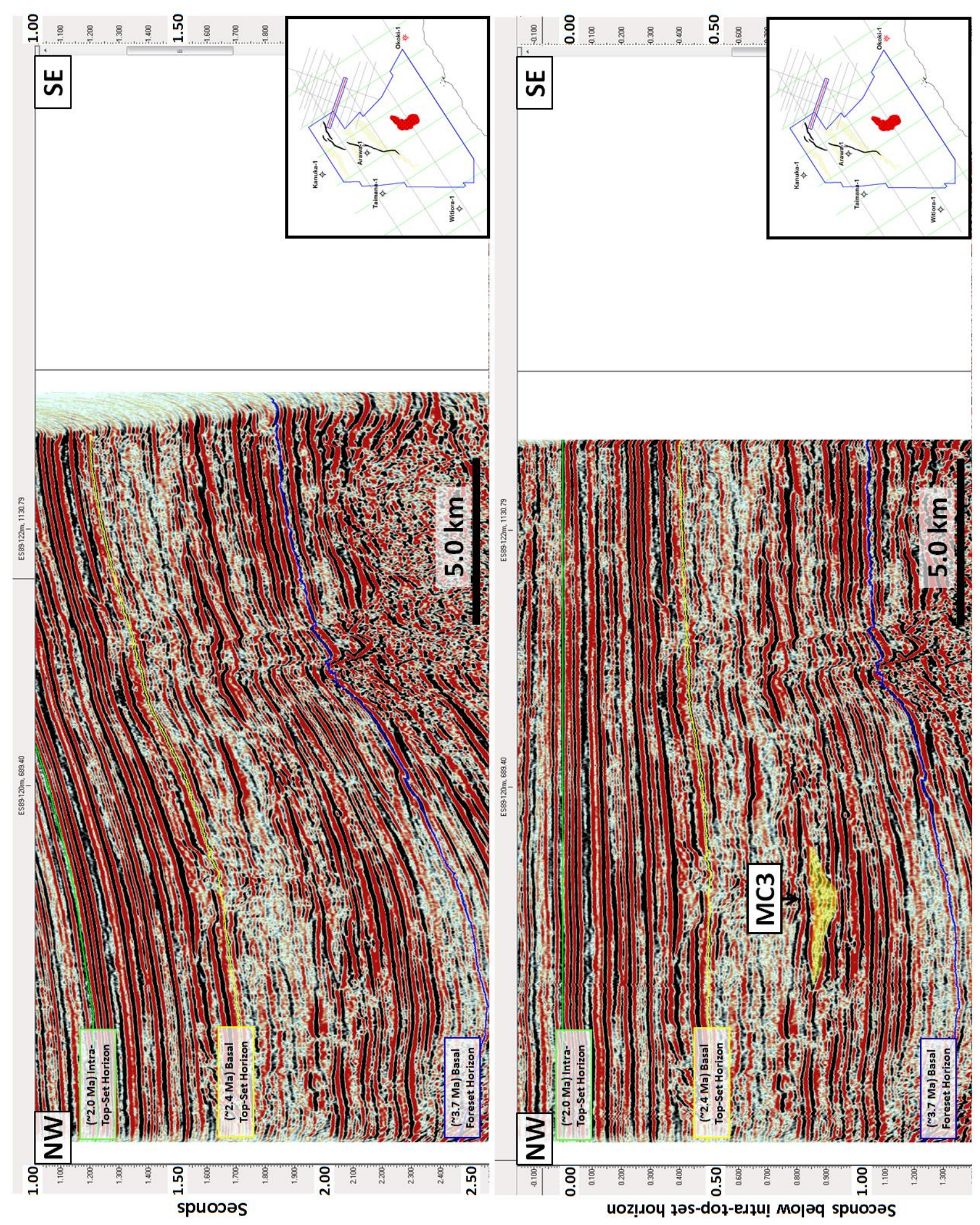

Appendix figure B.1k: Seismic cross-section of line ES89-114 of the ES89 2D seismic survey. The upper panel is a seismic section with horizons and annotated only. The lower panel is a seismic section flattened on the intra-top-set horizon and annotated with the position of the megachannel 3 (MC3) (highlighted by the transparent yellow polygon). Horizons are labelled with coloured boxes. The position of ES89-114 within the study area is shown in the inset panels (visible portion $=$ blue rectangle). Seismic polarity convention is red for negative and black for positive. 


\section{Acquisition Parameters}

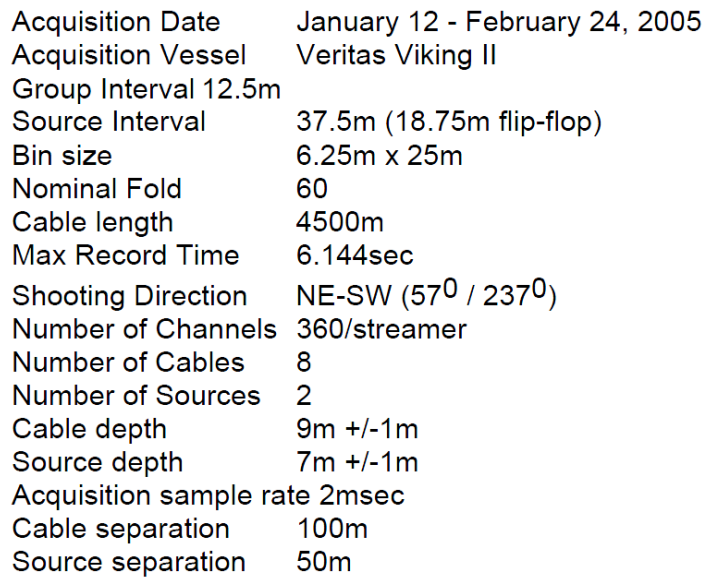

Processing Geometry

$\begin{array}{ll}\text { Record Length } & 6.144 \mathrm{sec} \\ \text { Sample Rate } & 4 \mathrm{msec} \\ \text { Fold Coverage } & 60 \\ \text { Preprocessing } & 6.25 \mathrm{~m} \times 25 \mathrm{~m} \\ \text { Final Output } & 12.5 \mathrm{~m} \times 12.5 \mathrm{~m}\end{array}$

Appendix figure C.1: Acquisition parameters for the Parihaka 3D seismic survey (Veritas, 2005).

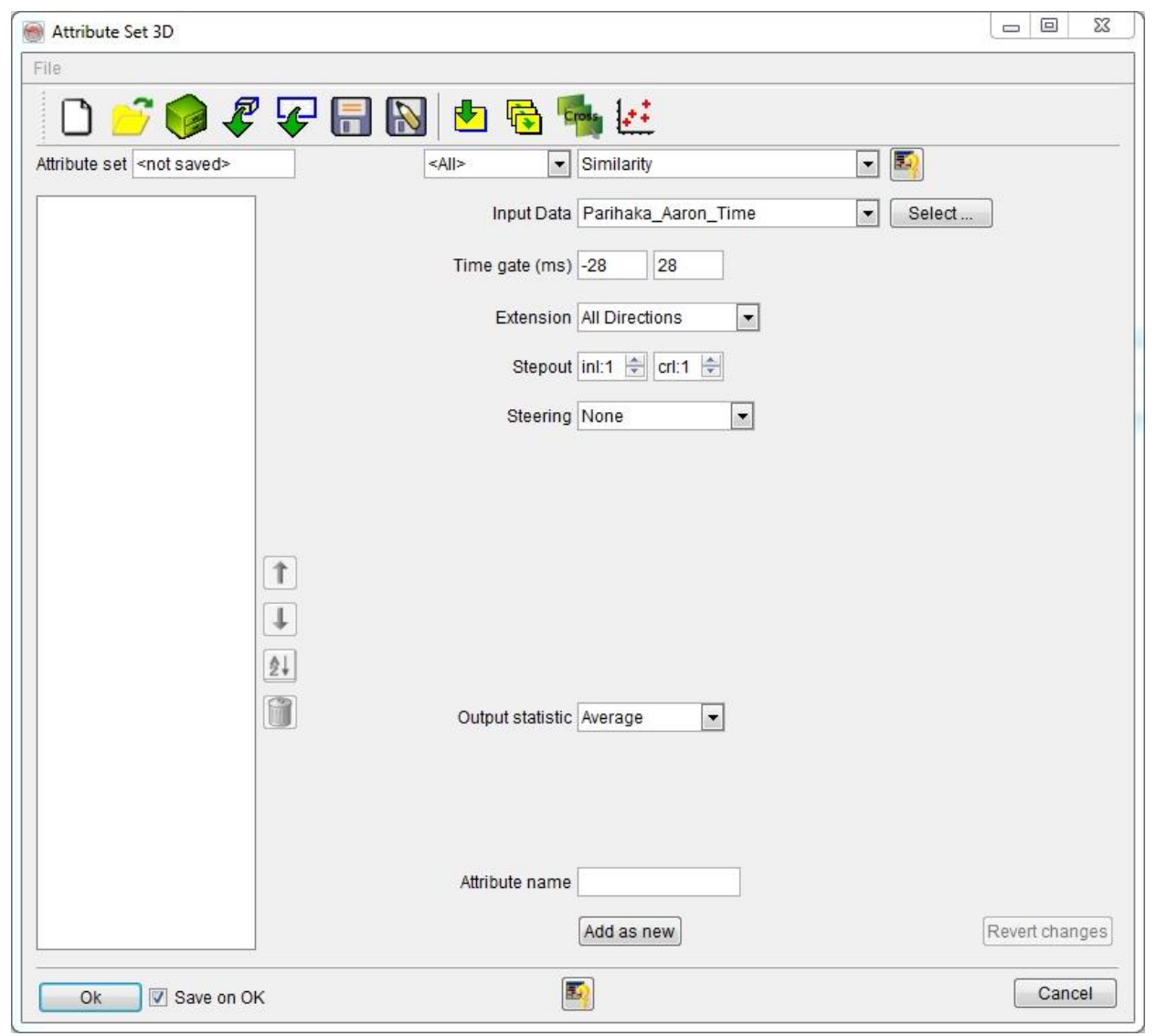

Appendix figure C.2: OpendTect settings from the coherency cube conversion of the Parihaka 3D seismic survey. 


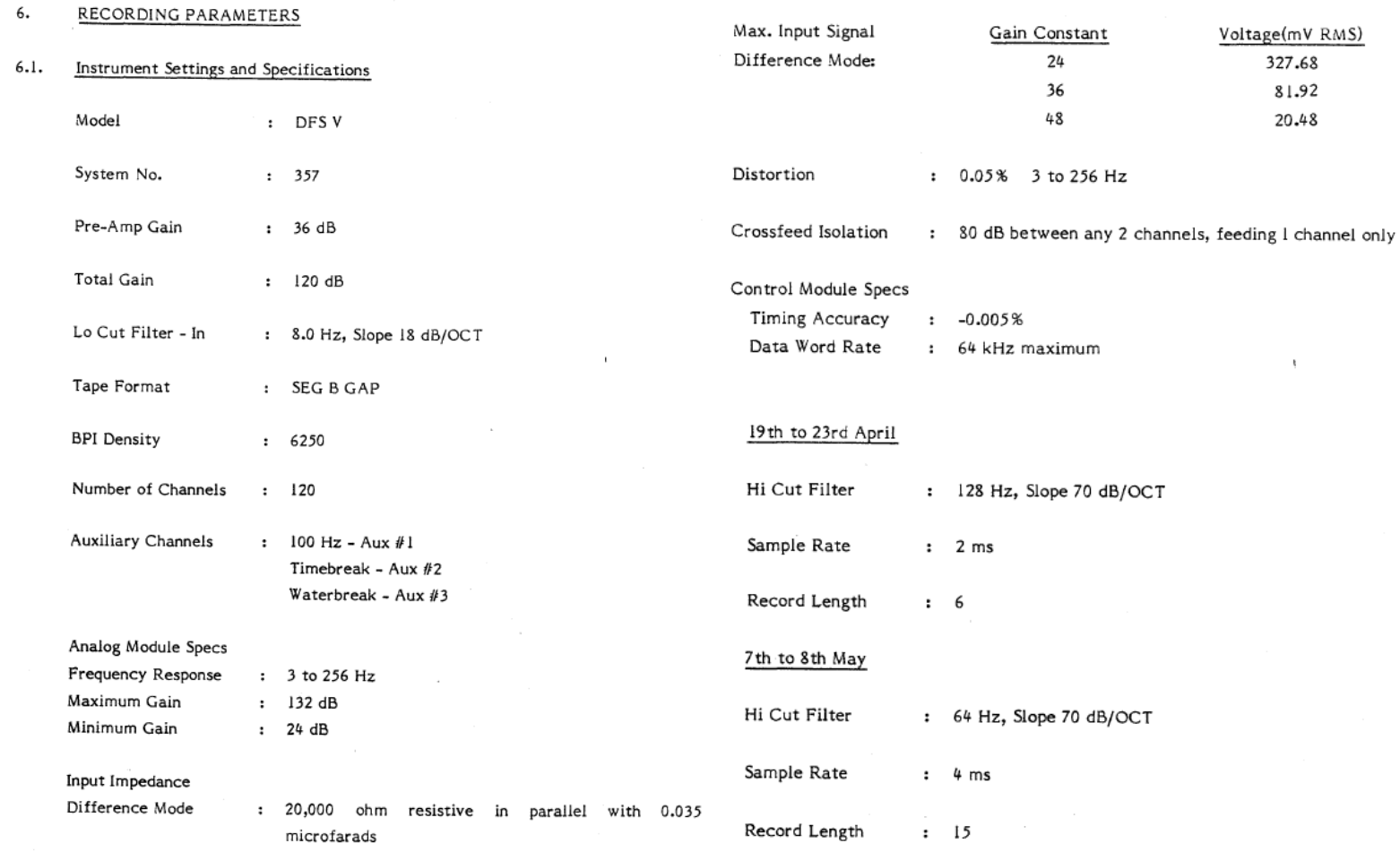

Appendix figure C.3: ES89 2D seismic survey acquisition parameters (GECO NZ, 1989).

\begin{tabular}{|c|c|c|c|c|c|c|c|}
\hline Client & : Todd Exploration Limited & Navig & ion Inf & mation & & & \\
\hline Project & : Parihaka 3D Reprocessing 2011 & Spher & & & GRS80 & & \\
\hline Survey & : Parihaka M3D & Geode & ic datu & & NZGD2000 & & \\
\hline Area & : Offshore Taranaki, NZ & Projec & on typ & & NZTM2000 & & \\
\hline Process & : PreSTM CMP gathers & 4 Cor & r Point & of Outp & ut Master Grid & & \\
\hline Data type & : Final PreSTM CMP gathers & & $\overline{\mathrm{X}-\mathrm{Coo}}$ & linates & Y-Coordinates & Xline & $\overline{\text { Inline }}$ \\
\hline & & MG1 & 164336 & .351 & 5646519.793 & 554 & 718 \\
\hline Inline Range & : 824-2815(incrl) & MG2 & 171615 & .766 & 5693862.169 & 7500 & 718 \\
\hline Xline Range & : $1012-7037$ (incr1) & MG3 & 161329 & .149 & 5692750.144 & 554 & 2924 \\
\hline Trace Length & $6144 \mathrm{~ms}$ (3 ms sampling rate) & MG4 & 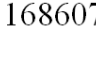 & .565 & 5740092.520 & 7500 & 2924 \\
\hline Data Format & SEG Y, 32 bit floating point & Inline & ell size & $25.0 \mathrm{~m}$ & & & \\
\hline Processing Pl & : Zero & Xline & 11 size & $12.5 \mathrm{~m}$ & & & \\
\hline Polarity & SEG Negative & Inlin & cremen & & & & \\
\hline Data format & SEG Y, IBM 32 bit floating point & Xline & cremen & & & & \\
\hline
\end{tabular}

Appendix figure C.4: Loading parameters for the 2011 PreSTM reprocessing version of the Parihaka 3D seismic survey. 
C01 SURVEY: ES89

C02 LINE: ES89-118

C03 AREA: OFFSHORE TARANAKI

$\mathrm{CO} 4$

C05 DATA TYPE: RAW MIGRATION

C06 NUMBER OF SAMPLES: 1501

C07 SAMPLE PERIOD: 4MS

$\mathrm{Cos}$

C09 PROCESSED BY: GECO N.Z.

C10 YEAR PROCESSED: 1989

C11

C12 =e=e=e=e=e=e=e=e=e=e=e=e=e=e=e=e=e=e=e=e=e=e=e=e=e=e=e=e=e=e=e=

C13 RECORDING PARAMETERS:

C14 SHOT BY: WESTERN GEOPHYSICAI

C15 YEAR SHOT: 1989

CABLE :

NO. GROUPS: 120

C16 BOAT: M/V WESTERN ORIENT

HYDROPHONES/GROUP: 20

C17 NAV.SYSTEM: SYLEDIS

OFFSET: 170.85

C18 DIR. SHOT: $287 \mathrm{DEG}$

C19 FOLD OF RECORDING: 60

GROUP INTERVAL: $25 \mathrm{M}$

CABLE DEPTH: 10M

C20

C21 ENERGY SOURCE: AIRGUNS

INSTRUMENTS: DFS $\mathrm{V}$

C22 TOTAL VOLUME: 1040 CU.IN.

FORMAT: SEGB 6250BPI

C23 TOTAL PRESSURE: 4500 PSI

SAMPLE RATE: 2MS

C24 SHOT INTERVAL: $25 \mathrm{M}$

RECORD LENGTH: $6 \mathrm{~S}$

C25 POP INTERVAL: 25M

LOWCUT FILTER: $8 \mathrm{HZ}$ 18DB/OCT

C26 SOURCE DEPTH: 6M

HIGHCUT FILTER: $128 \mathrm{HZ}$ 70DB/OCT

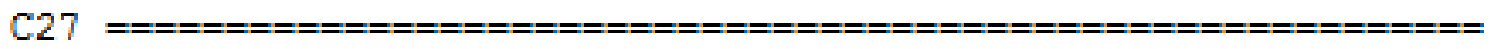

$\mathrm{C} 28$

C29 * ENTRIES MARKED WITH AN ASTERISK WERE INFERRED FROM

C30 EVIDENCE AVAILABLE WHEN THE ORIGINAL ARCHIVE TAPES WERE

C31 TRANSCRIBED. THIS INFORMATION WAS NOT EXPLICITLY STATED

C32 ON THE ORIGINAL TAPES OR SUPPORT DATA.

C33

C34 TRANSCRIBED FROM TAPE: BOT038 (SEGY FORMAT) TO SEGY

C35 BY ROBERTSON RESEARCH AUSTRALIA DECEMBER 1999

C36

C37 CDP/SHOT RELATIONSHIP:

C38 ES89-118 CDP $246==\operatorname{SP} 101$ *

C39 ES89-118 CDP $346==$ SP 151 *

C40 CDP RANGE: 127 TO 2216 SP RANGE: 101 TO 1086

Appendix figure C.5: Screenshot of the EBCDIC header from the raw migration SEG-Y file of the ES89-118 2D seismic line. 


\section{CENOZOIC}

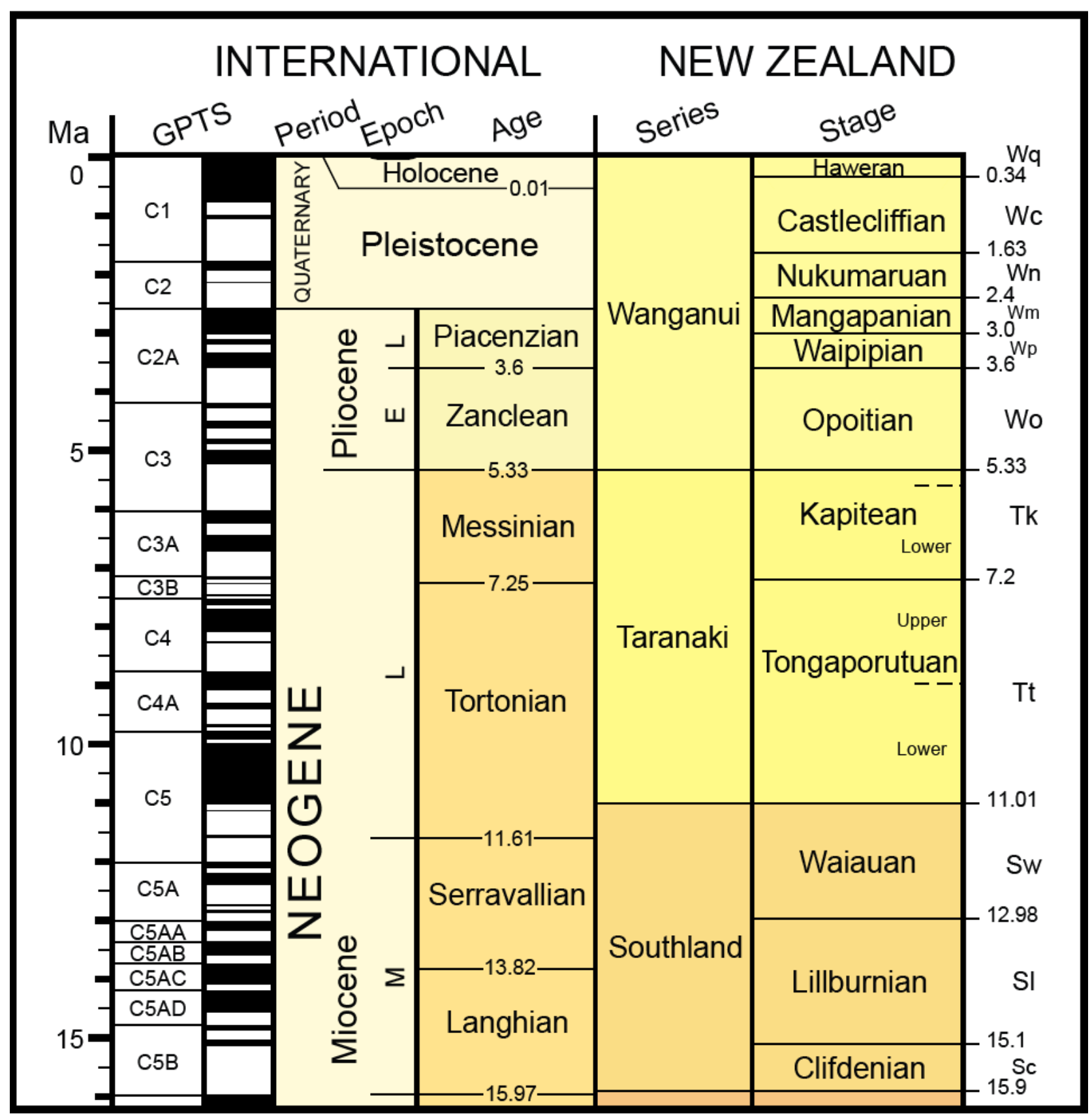

Appendix figure C.6: Geological time scale of the International and New Zealand time series covering the Middle Miocene-Recent period (modified after Hollis et al., 2010). 


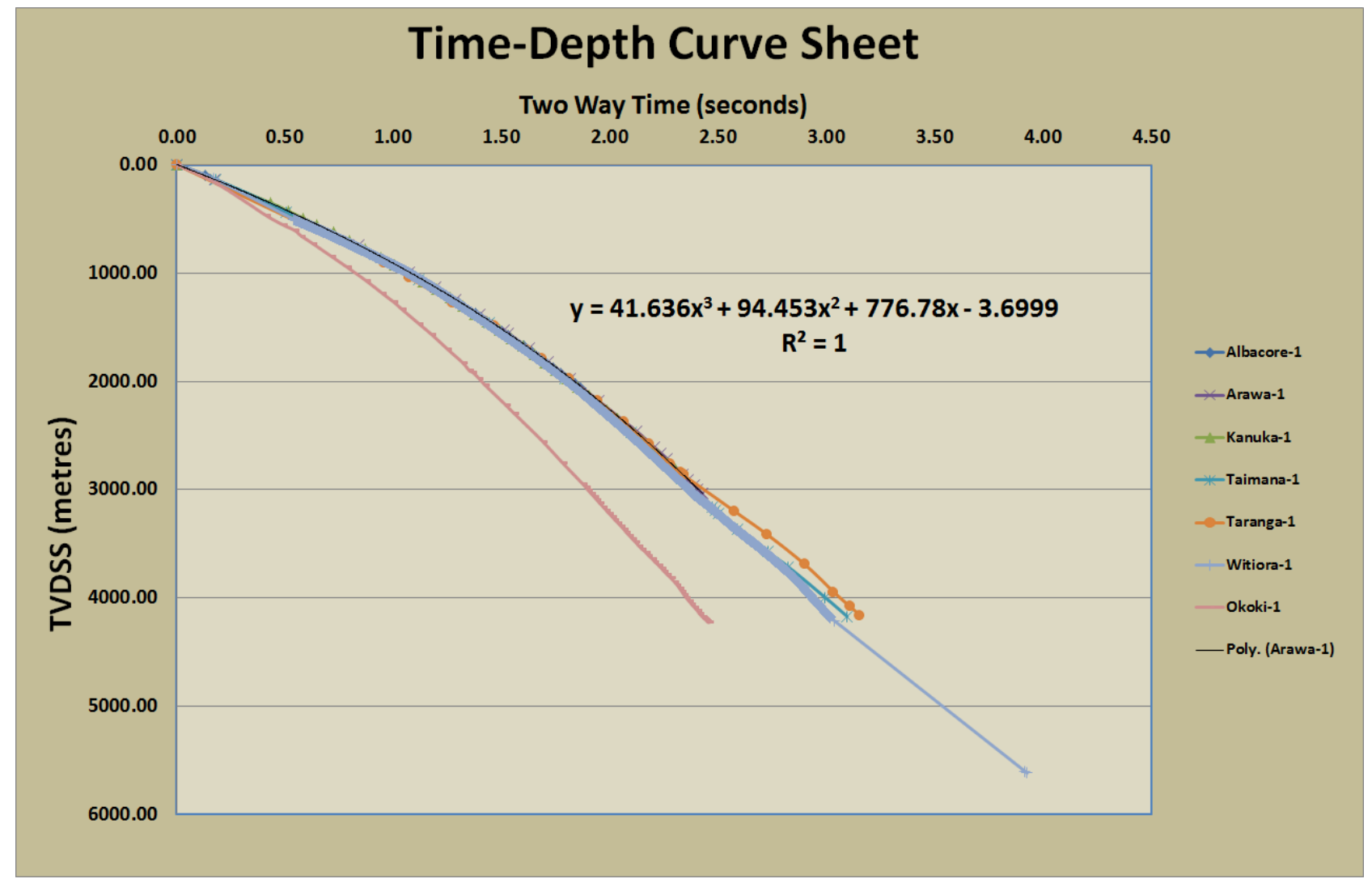

Appendix figure C.7: Graphed results of time-depth velocity surveys from wells proximal to and within the study area. TVDSS = True vertical depth sub-sea. Full results are included as appendix tables D.4.

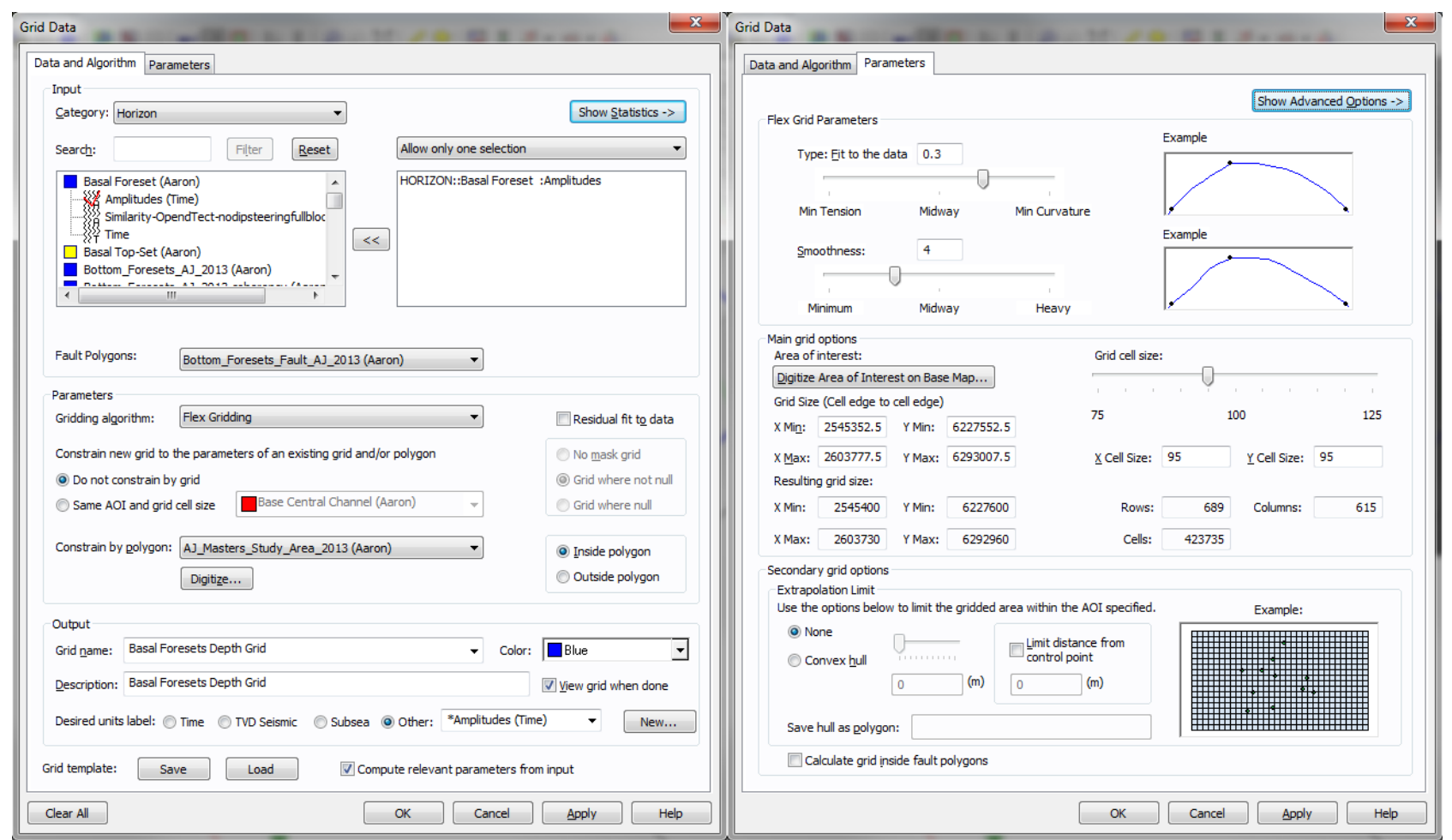

Appendix figure C.8: Final gridding parameters employed in the horizon to grid conversion process. 


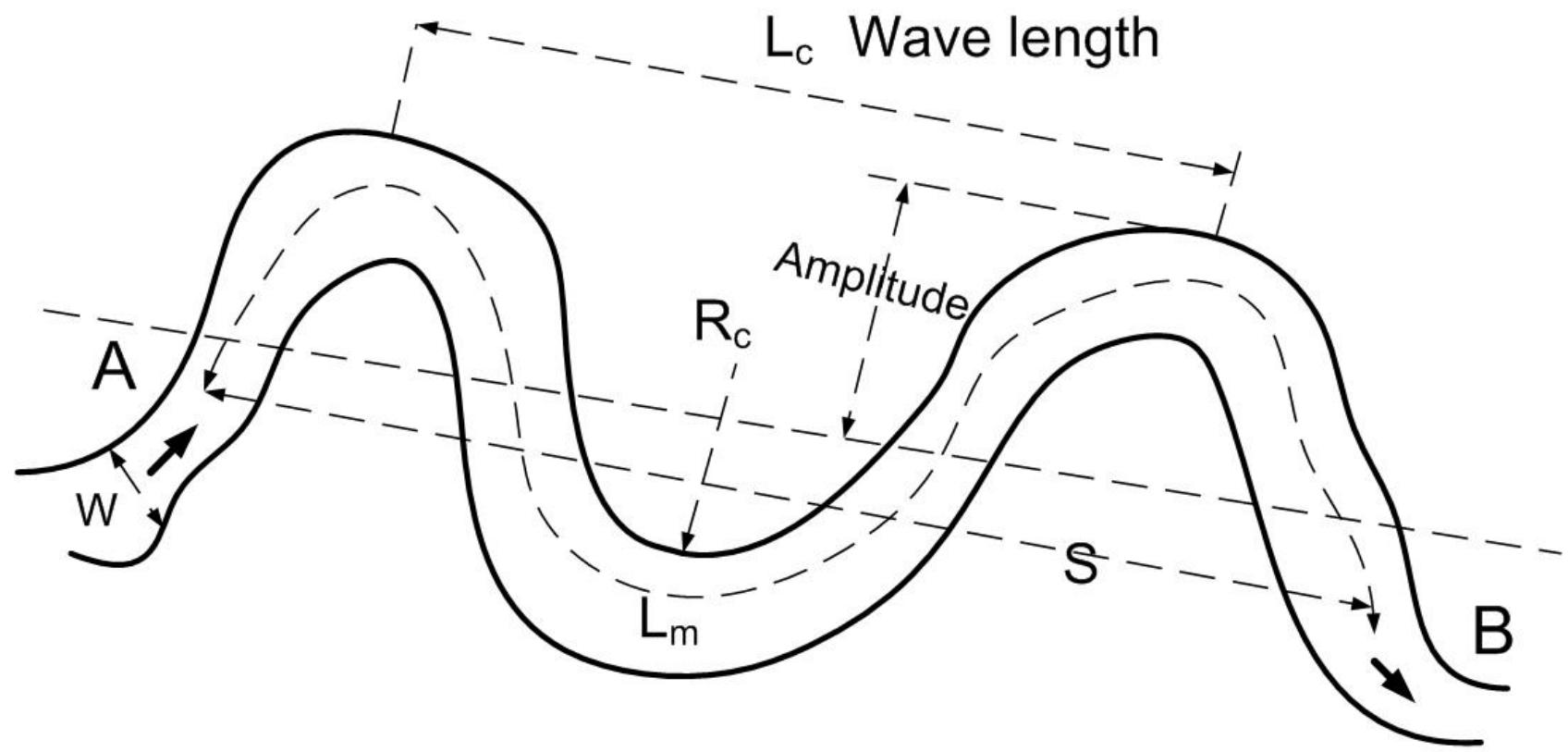

$L_{m}=$ Length of meander from $A$ to $B$

$S=$ Straight distance $A B$

\section{Geometric features of a meander}

Appendix figure C.9: Geometric features of a meandering channel. 


\section{D.1 List Of Nearby Exploration Wells}

\begin{tabular}{|c|c|c|c|c|c|c|c|}
\hline Well Name & $\begin{array}{c}\text { Total } \\
\text { Depth }(\mathrm{m})\end{array}$ & Spud Date & Operator & $\begin{array}{l}\text { Latitude } \\
\text { (WGS84) }\end{array}$ & $\begin{array}{c}\text { Longitude } \\
\text { (WGS84) }\end{array}$ & $\begin{array}{l}\text { Well Completion } \\
\text { Petroleum } \\
\text { Report Number }\end{array}$ & Well Completion Report Reference \\
\hline \multicolumn{8}{|c|}{ Wells Within Study Area } \\
\hline Arawa-1 & 3055.0 & December 1991 & ARCO Petroleum NZ Inc & -38.80389 & 173.71083 & PR1824 & $\begin{array}{l}\text { ARCO Petroleum, 1992. Arawa-1 Final well report } \\
\text { PPL38436. Ministry of Economic Development New } \\
\text { Zealand Unpublished Petroleum Report } 1824 .\end{array}$ \\
\hline Okoki-1 & 4257.0 & March 1989 & TCPL Resources Ltd & -38.92750 & 174.20472 & PR1495 & $\begin{array}{l}\text { TCPL Resources Ltd, 1989. Well Completion Report Okoki- } \\
1 \text { PPL38438. Ministry of Economic Development New } \\
\text { Zealand Unpublished Petroleum Report } 1495 .\end{array}$ \\
\hline Taimana-1 & 4195.0 & December 1983 & $\begin{array}{l}\text { Diamond Shamrock } \\
\text { Exploration Oil Co (NZ) }\end{array}$ & -38.85722 & 173.53889 & PR1026 & $\begin{array}{l}\text { Diamond Shamrock Exploration Oil Co (NZ), 1984. Final } \\
\text { Well Report Taimana-1 PPL 38109. Ministry of Economic } \\
\text { Development New Zealand Unpublished Petroleum } \\
\text { Report } 1026 .\end{array}$ \\
\hline Witiora-1 & 4229.0 & February 1984 & NZ Oil \& Gas Ltd & -39.11333 & 173.47500 & PR1037 & $\begin{array}{l}\text { New Zealand Oil \& Gas Ltd, 1984. Witiora-1 completion } \\
\text { report, PPL 38113. Offshore Taranaki. Ministry of } \\
\text { Economic Development New Zealand Unpublished } \\
\text { Petroleum Report } 1037 .\end{array}$ \\
\hline \multicolumn{8}{|c|}{ Nearby Wells } \\
\hline Kanuka-1 & 2879.0 & October 2007 & POGO New Zealand & -38.65531 & 173.61773 & PR3843 & $\begin{array}{l}\text { POGO New Zealand, 2007. Kanuka-1 End of Well } \\
\text { Completion Report. Ministry of Economic Development } \\
\text { New Zealand Unpublished Petroleum Report } 3843 .\end{array}$ \\
\hline Pohokura-1 & 4234.0 & February 2000 & $\begin{array}{c}\text { Fletcher Challenge Energy } \\
\text { Taranaki }\end{array}$ & -38.94871 & 174.29105 & PR2491 & $\begin{array}{l}\text { Fletcher Challenge Energy Taranaki, 2000. Pohokura-1 } \\
\text { Well Completion Report. Ministry of Economic } \\
\text { Development New Zealand Unpublished Petroleum } \\
\text { Report } 2491 .\end{array}$ \\
\hline Pohokura-2 & 3825.0 & May 2000 & $\begin{array}{c}\text { Fletcher Challenge Energy } \\
\text { Taranaki }\end{array}$ & -38.90989 & 174.26194 & PR2516 & $\begin{array}{l}\text { Fletcher Challenge Energy Taranaki, 2000. Pohokura-2 } \\
\text { Well Completion Report. Ministry of Economic } \\
\text { Development New Zealand Unpublished Petroleum } \\
\text { Report } 2516 .\end{array}$ \\
\hline Pohokura-3 & 3822.0 & October 2002 & Shell Todd Oil Services Ltd & -38.89292 & 174.25001 & PR2739 & $\begin{array}{l}\text { Shell Todd Oil Services Limited, 2002. Pohokura-3 Well } \\
\text { Completion Report. Ministry of Economic Development } \\
\text { New Zealand Unpublished Petroleum Report } 2739 .\end{array}$ \\
\hline Taranga-1 & 4250.0 & April 1992 & Shell Todd Oil Services Ltd & -38.97530 & 173.27333 & PR1864 & $\begin{array}{l}\text { Shell Todd Oil Services Limited, 1992. Taranga-1 well } \\
\text { completion report. PPL38444. Ministry of Economic } \\
\text { Development New Zealand Unpublished Petroleum } \\
\text { Report } 1864 .\end{array}$ \\
\hline
\end{tabular}

\section{D.2 Key Well Formation Tops}

\begin{tabular}{|c|c|c|c|c|}
\hline \multicolumn{5}{|c|}{ Arawa-1 Well Completion Report Formation Boundaries } \\
\hline $\begin{array}{c}\text { Formation Top } \\
\text { Depth }(\mathrm{m})\end{array}$ & Formation & $\begin{array}{c}\text { Thickness } \\
(\mathrm{m})\end{array}$ & $\begin{array}{c}\text { Petroleum } \\
\text { Report } \\
\text { Number }\end{array}$ & Reference \\
\hline 149.0 & Giant Foresets Formation & 1392.0 & \multirow{5}{*}{ PR1824 } & \multirow{5}{*}{$\begin{array}{l}\text { ARCO Petroleum NZ Inc (1992). Arawa-1 } \\
\text { Final well report PPL38436. Unpublished } \\
\text { Petroleum Report 1824, New Zealand } \\
\text { Petroleum \& Minerals, Wellington. }\end{array}$} \\
\hline 1541.0 & Urenui Formation & 539.0 & & \\
\hline 2080.0 & Mohakatino Formation & 646.0 & & \\
\hline 2726.0 & Mokau Formation & 222.0 & & \\
\hline 2948.0 & Moki Sandstone & $107.0+$ & & \\
\hline
\end{tabular}

\begin{tabular}{|c|c|c|c|c|}
\hline \multicolumn{5}{|c|}{ Okoki-1 Well Completion Report Formation Boundaries } \\
\hline $\begin{array}{l}\text { Formation Top } \\
\text { Depth (m) }\end{array}$ & Formation & $\begin{array}{l}\text { Thickness } \\
\text { (m) }\end{array}$ & $\begin{array}{c}\text { Petroleum } \\
\text { Report } \\
\text { Number }\end{array}$ & Reference \\
\hline 71.0 & Matemateaonga Formation & 689.0 & \multirow{8}{*}{ PR1495 } & \multirow{8}{*}{$\begin{array}{l}\text { TCPL Resources Ltd (1989). Well Completion } \\
\text { Report Okoki-1 PPL38438. Unpublished } \\
\text { Petroleum Report 1495, New Zealand } \\
\text { Petroleum \& Minerals, Wellington. }\end{array}$} \\
\hline 760.0 & Urenui Formation & 445.0 & & \\
\hline 1205.0 & $\begin{array}{l}\text { Mt Messenger-Mohakatino } \\
\text { Formations }\end{array}$ & 606.0 & & \\
\hline 1811.0 & Moki Formation & 196.0 & & \\
\hline 2007.0 & Manganui Formation & 1427.0 & & \\
\hline 3434.0 & Taimana-Otaraoa Formations & 134.0 & & \\
\hline 3568.0 & Turi Formation & 310.0 & & \\
\hline 3878.0 & Maui Formation & $379.5+$ & & \\
\hline
\end{tabular}


Taimana-1 Well Completion Report Formation Boundaries

\begin{tabular}{|c|c|c|c|c|}
\hline \multicolumn{5}{|c|}{ Taimana-1 Well Completion Report Formation Boundaries } \\
\hline $\begin{array}{c}\text { Formation Top } \\
\text { Depth }(\mathrm{m})\end{array}$ & Formation & $\begin{array}{c}\text { Thickness } \\
\text { (m) }\end{array}$ & $\begin{array}{c}\text { Petroleum } \\
\text { Report } \\
\text { Number }\end{array}$ & Reference \\
\hline 160.0 & Giant Foresets Formation & 1336.0 & \multirow{8}{*}{ PR1026 } & \multirow{8}{*}{$\begin{array}{c}\text { Diamond Shamrock Exploration Oil Co (NZ) } \\
\text { (1984). Final Well Report Taimana-1 PPL } \\
\text { 38109. Unpublished Petroleum Report 1026, } \\
\text { New Zealand Petroleum \& Minerals, } \\
\text { Wellington. }\end{array}$} \\
\hline 1496.0 & $\begin{array}{l}\text { Waikiekie-Mohakatino } \\
\text { Formations }\end{array}$ & 992.5 & & \\
\hline 2488.5 & Mokau Formation & 361.8 & & \\
\hline 2850.3 & Mahoenui Formation & 340.5 & & \\
\hline 3190.8 & Tikorangi Limestone & 59.2 & & \\
\hline 3250.0 & Kaiata Formation & 139.0 & & \\
\hline 3389.0 & Upper Kapuni Formation & 351.2 & & \\
\hline 3740.2 & Lower Kapuni Formation & $459.5+$ & & \\
\hline
\end{tabular}

\begin{tabular}{|c|c|c|c|c|}
\hline \multicolumn{5}{|c|}{ Witiora-1 Well Completion Report Formation Boundaries } \\
\hline $\begin{array}{c}\text { Formation Top } \\
\text { Depth (m) }\end{array}$ & Formation & $\begin{array}{c}\text { Thickness } \\
\text { (m) }\end{array}$ & $\begin{array}{c}\text { Petroleum } \\
\text { Report } \\
\text { Number }\end{array}$ & Reference \\
\hline 154.5 & Giant Foresets Formation & 1304.5 & \multirow{10}{*}{ PR1037 } & \multirow{10}{*}{$\begin{array}{c}\text { New Zealand Oil \& Gas Ltd (1984). Witiora-1 } \\
\text { completion report, PPL 38113. Offshore } \\
\text { Taranaki. Unpublished Petroleum Report } \\
\text { 1037, New Zealand Petroleum \& Minerals, } \\
\text { Wellington. }\end{array}$} \\
\hline 1459.0 & Urenui Mudstone & 506.0 & & \\
\hline 1965.0 & Mohakatino Formation & 627.0 & & \\
\hline 2592.0 & Mokau Group & 369.0 & & \\
\hline 2961.0 & Mahoenui Mudstone & 46.0 & & \\
\hline 3007.0 & Te Kuiti Limestone & 63.0 & & \\
\hline 3070.0 & Kaiata Sandstone & 140.0 & & \\
\hline 3210.0 & Moa Siltstone & 711.5 & & \\
\hline 3921.5 & Basal Sandstone & 301.0 & & \\
\hline 4222.5 & Granite Basement & $6.5+$ & & \\
\hline
\end{tabular}

\section{D.3 Key Well Biostratigraphy Interval Results}

\begin{tabular}{|c|c|c|c|c|c|}
\hline \multicolumn{6}{|c|}{ Arawa-1 Paleoenvironment Zone Data } \\
\hline $\begin{array}{l}\text { Top Zone } \\
\text { Depth (m) }\end{array}$ & \begin{tabular}{|c|} 
Bottom Zone \\
Depth $(\mathrm{m})$
\end{tabular} & $\begin{array}{c}\text { Envi. } \\
\text { Abbrev. }\end{array}$ & Environment & $\begin{array}{c}\text { Pertroleum Report } \\
\text { Number }\end{array}$ & Reference \\
\hline 668.0 & 740.0 & ish & Inner shelf & \multirow{9}{*}{ PR3534 } & \multirow{9}{*}{$\begin{array}{l}\text { Morgans, H. 2006. Foraminiferal } \\
\text { Biostratigraphy of the Early Miocene to } \\
\text { Pleistocene Sequences in Witiora-1, } \\
\text { Taimana-1, Arawa-1 and Okoki-1, GNS } \\
\text { Science Report, 2006/37, 41p. }\end{array}$} \\
\hline 805.0 & 880.0 & m-osh & Mid-outer shelf & & \\
\hline 945.0 & 1230.0 & msh & Mid shelf & & \\
\hline 1295.0 & 1370.0 & osh & Outer shelf & & \\
\hline 1435.0 & 1518.0 & subath & Shallow upper bathyal & & \\
\hline 1524.0 & 1650.0 & ubath & Upper bathyal & & \\
\hline 1716.0 & 2001.0 & mbath & Mid bathyal & & \\
\hline 2067.0 & 2211.0 & ubath & Upper bathyal & & \\
\hline 2277.0 & 3055.0 & m-lbath & Mid-lower bathyal & & \\
\hline \multicolumn{6}{|c|}{ Arawa-1 New Zealand Stage Zone Data } \\
\hline $\begin{array}{l}\text { Top Zone } \\
\text { Depth (m) }\end{array}$ & \begin{tabular}{|c|} 
Bottom Zone \\
Depth $(\mathrm{m})$
\end{tabular} & $\begin{array}{c}\text { Age } \\
\text { Abbrev. }\end{array}$ & Age & $\begin{array}{c}\text { Pertroleum Report } \\
\text { Number }\end{array}$ & Reference \\
\hline 668.0 & 1010.0 & Wc-eWn & Castlecliffian-Early Nukumaruan & \multirow{7}{*}{ PR3534 } & \multirow{7}{*}{$\begin{array}{l}\text { Morgans, H. 2006. Foraminiferal } \\
\text { Biostratigraphy of the Early Miocene to } \\
\text { Pleistocene Sequences in Witiora-1, } \\
\text { Taimana-1, Arawa-1 and Okoki-1, GNS } \\
\text { Science Report, 2006/37, 41p. }\end{array}$} \\
\hline 1010.0 & 1521.0 & $\mathrm{eWn}-\mathrm{Wm}$ & Early Nukumaruan-Mangapanian & & \\
\hline 1521.0 & 1760.0 & Wo & Opoitian & & \\
\hline 1760.0 & 1960.0 & ITk & Late Kapitean & & \\
\hline 1960.0 & 2620.0 & eTk-ITt & Early Kapitean-Late Tongaporutuan & & \\
\hline 2620.0 & 2988.0 & $\mathrm{eTt}$ & Early Tongaporutuan & & \\
\hline 2988.0 & 3055.0 & Sw & Waiauan & & \\
\hline
\end{tabular}




\begin{tabular}{|c|c|c|c|c|c|}
\hline & & & Okoki-1 Paleoenvironment & Zone Data & \\
\hline $\begin{array}{l}\text { Top Zone } \\
\text { Depth (m) }\end{array}$ & $\begin{array}{c}\text { Bottom Zone } \\
\text { Depth (m) }\end{array}$ & $\begin{array}{c}\text { Envi. } \\
\text { Abbrev. }\end{array}$ & Environment & $\begin{array}{c}\text { Pertroleum } \\
\text { Report Number }\end{array}$ & Reference \\
\hline 200.0 & 310.0 & msh & Mid shelf & \multirow{13}{*}{ PR3534 } & \multirow{13}{*}{$\begin{array}{l}\text { Morgans, H. 2006. Foraminiferal } \\
\text { Biostratigraphy of the Early Miocene to } \\
\text { Pleistocene Sequences in Witiora-1, } \\
\text { Taimana-1, Arawa-1 and Okoki-1, GNS } \\
\text { Science Report, 2006/37, 41p. }\end{array}$} \\
\hline 340.0 & 560.0 & m-osh & Mid-outer shelf & & \\
\hline 790.0 & 800.0 & ubath & Upper bathyal & & \\
\hline 950.0 & 960.0 & mbath & Mid bathyal & & \\
\hline 990.0 & 1020.0 & Ibath & Lower bathyal & & \\
\hline 1025.0 & 1360.0 & ubath & Upper bathyal & & \\
\hline 1395.0 & 3025.0 & Ibath & Lower bathyal & & \\
\hline 3100.0 & 3400.0 & m-lbath & Mid-lower bathyal & & \\
\hline 3450.0 & 3479.0 & u-mbath & Upper-mid bathyal & & \\
\hline 3510.0 & 3550.0 & osh & Outer shelf & & \\
\hline 3560.0 & 3777.0 & i-msh & Inner-mid shelf & & \\
\hline 3795.0 & 4002.0 & ish & Inner shelf & & \\
\hline 4005.0 & 4245.0 & nrsh & Nearshore/paralic/shoreface & & \\
\hline \multicolumn{6}{|c|}{ Okoki-1 New Zealand Stage Zone Data } \\
\hline $\begin{array}{l}\text { Top Zone } \\
\text { Depth }(\mathrm{m})\end{array}$ & $\begin{array}{c}\text { Bottom Zone } \\
\text { Depth }(\mathrm{m})\end{array}$ & $\begin{array}{c}\text { Age } \\
\text { Abbrev. }\end{array}$ & Age & $\begin{array}{c}\text { Pertroleum } \\
\text { Report Number }\end{array}$ & Reference \\
\hline 200.0 & 1235.0 & $\mathrm{eTk}-\mathrm{TTt}$ & Early Kapitean-Late Tongaporutuan & \multirow{13}{*}{ PR3534 } & \multirow{13}{*}{$\begin{array}{l}\text { Morgans, H. 2006. Foraminiferal } \\
\text { Biostratigraphy of the Early Miocene to } \\
\text { Pleistocene Sequences in Witiora-1, } \\
\text { Taimana-1, Arawa-1 and Okoki-1, GNS } \\
\text { Science Report, 2006/37, 41p. }\end{array}$} \\
\hline 1235.0 & 2045.0 & $\mathrm{eTt}$ & Early Tongaporutuan & & \\
\hline 2045.0 & 2105.0 & $S w$ & Waiauan & & \\
\hline 2105.0 & 2235.0 & SI & Lillburnian & & \\
\hline 2235.0 & 2275.0 & Sc & Clifdenian & & \\
\hline 2275.0 & 3050.0 & $\mathrm{PI}$ & Altonian & & \\
\hline 3050.0 & 3425.0 & Po-ILw & Otaian-Late Waitakian & & \\
\hline 3425.0 & 3490.0 & eLw & Early Waitakian & & \\
\hline 3490.0 & 3510.0 & Ld & Duntroonian & & \\
\hline 3510.0 & 3555.0 & ILwh & Late Whaingaroan & & \\
\hline 3555.0 & 3650.0 & $\mathrm{Ar}$ & Runangan & & \\
\hline 3650.0 & 4015.0 & Ak-Ab & Kaiatan-Bortonian & & \\
\hline 4015.0 & 4245.0 & $A b$ & Bortonian & & \\
\hline
\end{tabular}

\begin{tabular}{|c|c|c|c|c|c|}
\hline \multicolumn{6}{|c|}{ Taimana-1 Paleoenvironment Zone Data } \\
\hline $\begin{array}{l}\text { Top Zone } \\
\text { Depth }(m)\end{array}$ & \begin{tabular}{|c|} 
Bottom Zone \\
Depth $(\mathrm{m})$
\end{tabular} & $\begin{array}{c}\text { Envi. } \\
\text { Abbrev. }\end{array}$ & Environment & \begin{tabular}{|c|} 
Pertroleum \\
Report Number
\end{tabular} & Reference \\
\hline 220.0 & 680.0 & sh & Shelf & \multirow{12}{*}{ PR3534 } & \multirow{12}{*}{$\begin{array}{c}\text { Morgans, H. 2006. Foraminiferal } \\
\text { Biostratigraphy of the Early Miocene to } \\
\text { Pleistocene Sequences in Witiora-1, } \\
\text { Taimana-1, Arawa-1 and Okoki-1, GNS } \\
\text { Science Report, 2006/37, 41p. }\end{array}$} \\
\hline 730.0 & 930.0 & msh-ubath & Mid shelf-upper bathyal & & \\
\hline 950.0 & 1030.0 & m-osh & Mid-outer shelf & & \\
\hline 1050.0 & 1270.0 & osh-ubath & Outer shelf-upper bathyal & & \\
\hline 1270.0 & 1430.0 & dubath & Deep upper bathyal & & \\
\hline 1450.0 & 1710.0 & mbath & Mid bathyal & & \\
\hline 1720.0 & 1925.0 & m-osh? & Mid-outer shelf? & & \\
\hline 2025.0 & 2625.0 & osh-ubath & Outer shelf-upper bathyal & & \\
\hline 2625.0 & 2825.0 & m-lbath & Mid-lower bathyal & & \\
\hline 2925.0 & 3225.0 & mbath & Mid bathyal & & \\
\hline 3255.0 & 3466.0 & osh-ubath & Outer shelf-upper bathyal & & \\
\hline 3505.0 & 4184.0 & i-msh & Inner-mid shelf & & \\
\hline \multicolumn{6}{|c|}{ Taimana-1 New Zealand Stage Zone Data } \\
\hline $\begin{array}{l}\text { Top Zone } \\
\text { Depth }(m)\end{array}$ & \begin{tabular}{|c|} 
Bottom Zone \\
Depth $(\mathrm{m})$
\end{tabular} & $\begin{array}{c}\text { Age } \\
\text { Abbrev. }\end{array}$ & Age & \begin{tabular}{|c|} 
Pertroleum \\
Report Number
\end{tabular} & Reference \\
\hline 220.0 & 360.0 & Wc-Wn & Castlecliffian-Nukumaruan & \multirow{21}{*}{ PR3534 } & \multirow{21}{*}{$\begin{array}{c}\text { Morgans, H. 2006. Foraminiferal } \\
\text { Biostratigraphy of the Early Miocene to } \\
\text { Pleistocene Sequences in Witiora-1, } \\
\text { Taimana-1, Arawa-1 and Okoki-1, GNS } \\
\text { Science Report, 2006/37, 41p. }\end{array}$} \\
\hline 360.0 & 920.0 & Wn & Nukumaruan & & \\
\hline 920.0 & 980.0 & eeWn & Earliest Nukumaruan & & \\
\hline 980.0 & 1175.0 & Wm & Mangapanian & & \\
\hline 1175.0 & 1470.0 & Wp-IWo & Waipipian-Late Opoitian & & \\
\hline 1470.0 & 1575.0 & m-eWo & Mid-Early Opoitian & & \\
\hline 1575.0 & 1635.0 & ITk & Late Kapitean & & \\
\hline 1635.0 & 2635.0 & eTk-ITt & Early Kapitean-Late Tongaporutuan & & \\
\hline 2635.0 & 2880.0 & $\mathrm{eTt}$ & Early Tongaporutuan & & \\
\hline 2880.0 & 2960.0 & SI & Lillburnian & & \\
\hline 2960.0 & 3020.0 & Sc & Clifdenian & & \\
\hline 3020.0 & 3140.0 & PI & Altonian & & \\
\hline 3140.0 & 3182.0 & Lw-Ld & Waitakian-Duntroonian & & \\
\hline 3182.0 & 3250.0 & Lwh & Whaingaroan & & \\
\hline 3250.0 & 3285.0 & Ar-Ak & Runangan-Kaiatan & & \\
\hline 3285.0 & 3685.0 & $\mathrm{Ab}$ & Bortonian & & \\
\hline 3685.0 & 3715.0 & Dp & Porangan & & \\
\hline 3715.0 & 3901.0 & $\mathrm{Dh}$ & Heretaungan & & \\
\hline 3901.0 & 3928.0 & $\mathrm{Dm}$ & Mangaorapan & & \\
\hline 3928.0 & 4175.0 & Dw & Waipawan & & \\
\hline 4175.0 & 4184.0 & $\mathrm{Dt}$ & Teurian & & \\
\hline
\end{tabular}


Witiora-1 Paleoenvironment Zone Data

\begin{tabular}{|c|c|c|c|c|c|}
\hline \multicolumn{6}{|c|}{ Witiora-1 Paleoenvironment Zone Data } \\
\hline $\begin{array}{l}\text { Top Zone } \\
\text { Depth (m) }\end{array}$ & $\begin{array}{c}\text { Bottom Zone } \\
\text { Depth (m) }\end{array}$ & $\begin{array}{l}\text { Envi. } \\
\text { Abbrev. }\end{array}$ & Environment & $\begin{array}{l}\text { Pertroleum } \\
\text { Report } \\
\text { Number }\end{array}$ & Reference \\
\hline 220.0 & 610.0 & ish & Inner shelf & \multirow{16}{*}{ PR3534 } & \multirow{16}{*}{$\begin{array}{l}\text { Morgans, H. 2006. Foraminiferal } \\
\text { Biostratigraphy of the Early Miocene to } \\
\text { Pleistocene Sequences in Witiora-1, } \\
\text { Taimana-1, Arawa-1 and Okoki-1, GNS } \\
\text { Science Report, 2006/37, 41p. }\end{array}$} \\
\hline 650.0 & 680.0 & msh-subath & Mid shelf-shallow upper bathyal & & \\
\hline 700.0 & 710.0 & ish & Inner shelf & & \\
\hline 750.0 & 760.0 & msh & Mid shelf & & \\
\hline 800.0 & 810.0 & i-msh & Inner-mid shelf & & \\
\hline 900.0 & 1210.0 & m-osh & Mid-outer shelf & & \\
\hline 1220.0 & 1930.0 & ubath & Upper bathyal & & \\
\hline 1970.0 & 2205.0 & mbath & Mid bathyal & & \\
\hline 2225.0 & 2405.0 & Ibath & Lower bathyal & & \\
\hline 2420.0 & 2470.0 & m-lbath & Mid-lower bathyal & & \\
\hline 2470.0 & 2730.0 & Ibath & Lower bathyal & & \\
\hline 2775.0 & 3045.0 & m-lbath & Mid-lower bathyal & & \\
\hline 3050.0 & 3064.2 & u-mbath & Upper-mid bathyal & & \\
\hline 3070.0 & 3078.0 & ubath & Upper bathyal & & \\
\hline 3085.0 & 3145.0 & msh & Mid shelf & & \\
\hline 3150.0 & 4225.0 & m-osh & Mid-outer shelf & & \\
\hline \multicolumn{6}{|c|}{ Witiora-1 New Zealand Stage Zone Data } \\
\hline $\begin{array}{l}\text { Top Zone } \\
\text { Depth (m) }\end{array}$ & $\begin{array}{l}\text { Bottom Zone } \\
\text { Depth }(\mathrm{m})\end{array}$ & $\begin{array}{c}\text { Age } \\
\text { Abbrev. }\end{array}$ & Age & $\begin{array}{c}\text { Pertroleum } \\
\text { Report } \\
\text { Number }\end{array}$ & Reference \\
\hline 220.0 & 700.0 & R-Wn & Recent-Nukumaruan & \multirow{23}{*}{ PR3534 } & \multirow{23}{*}{$\begin{array}{l}\text { Morgans, H. 2006. Foraminiferal } \\
\text { Biostratigraphy of the Early Miocene to } \\
\text { Pleistocene Sequences in Witiora-1, } \\
\text { Taimana-1, Arawa-1 and Okoki-1, GNS } \\
\text { Science Report, 2006/37, 41p. }\end{array}$} \\
\hline 700.0 & 720.0 & $W \mathrm{~m}$ & Mangapanian & & \\
\hline 720.0 & 1060.0 & Wp-IWo & Waipipian-Late Opoitian & & \\
\hline 1060.0 & 1215.0 & m-eWo & Mid-Early Opoitian & & \\
\hline 1215.0 & 1320.0 & ITk & Late Kapitean & & \\
\hline 1320.0 & 1360.0 & eTk & Early Kapitean & & \\
\hline 1360.0 & 2440.0 & eTk-ITt & Early Kapitean-Late Tongaporutuan & & \\
\hline 2440.0 & 2590.0 & $\mathrm{eTt}$ & Early Tongaporutuan & & \\
\hline 2590.0 & 2625.0 & Sw & Waiauan & & \\
\hline 2625.0 & 2812.0 & SI & Lillburnian & & \\
\hline 2812.0 & 2915.0 & Sc & Clifdenian & & \\
\hline 2915.0 & 3020.0 & I-mPI & Late-Mid Altonian & & \\
\hline 3020.0 & 3035.0 & Po-ILw & Otaian-Late Waitakian & & \\
\hline 3035.0 & 3045.0 & ILwh & Late Whaingaroan & & \\
\hline 3045.0 & 3067.0 & eLwh & Early Whaingaroan & & \\
\hline 3067.0 & 3080.0 & $\mathrm{Ar}$ & Runangan & & \\
\hline 3080.0 & 3150.0 & Ak & Kaiatan & & \\
\hline 3150.0 & 3430.0 & $A b$ & Bortonian & & \\
\hline 3430.0 & 3455.0 & $A b-D p$ & Bortonian-Porangan & & \\
\hline 3455.0 & 3586.0 & Dh-Dm & Heretaungan-Mangaorapan & & \\
\hline 3586.0 & 3915.0 & Dw & Waipawan & & \\
\hline 3915.0 & 4215.5 & $\mathrm{Dt}$ & Teurian & & \\
\hline 3915.0 & 4225.0 & $\mathrm{Mh}$ & Haumurian & & \\
\hline
\end{tabular}




\section{D.4 Key Well Time-Depth Curve Results}

\begin{tabular}{|c|c|c|c|c|}
\hline \multicolumn{5}{|c|}{ Arawa-1 Time-Depth Results } \\
\hline $\begin{array}{c}\text { True Vertical } \\
\text { Depth Sub-Sea } \\
\text { (m) }\end{array}$ & TWT (sec) & TWT (msec) & $\begin{array}{l}\text { Petroleum } \\
\text { Report } \\
\text { Number }\end{array}$ & Reference \\
\hline 0.0 & 0.0000 & 0.00 & \multirow{23}{*}{ PR1824 } & \multirow{23}{*}{$\begin{array}{l}\text { ARCO Petroleum NZ Inc, 1992. Arawa-1 } \\
\text { Final well report PPL38436. Ministry of } \\
\text { Economic Development New Zealand } \\
\text { Unpublished Petroleum Report } 1824 .\end{array}$} \\
\hline 132.0 & 0.1760 & 176.00 & & \\
\hline 738.8 & 0.8426 & 842.60 & & \\
\hline 992.7 & 1.0728 & 1072.80 & & \\
\hline 1132.6 & 1.1970 & 1197.00 & & \\
\hline 1246.6 & 1.2890 & 1289.00 & & \\
\hline 1378.9 & 1.4000 & 1400.00 & & \\
\hline 1524.9 & 1.5092 & 1509.20 & & \\
\hline 1558.7 & 1.5322 & 1532.20 & & \\
\hline 1695.9 & 1.6282 & 1628.20 & & \\
\hline 1820.9 & 1.7152 & 1715.20 & & \\
\hline 1976.6 & 1.8192 & 1819.20 & & \\
\hline 2178.7 & 1.9474 & 1947.40 & & \\
\hline 2464.9 & 2.1254 & 2125.40 & & \\
\hline 2610.9 & 2.2064 & 2206.40 & & \\
\hline 2662.7 & 2.2354 & 2235.40 & & \\
\hline 2714.9 & 2.2634 & 2263.40 & & \\
\hline 2864.8 & 2.3394 & 2339.40 & & \\
\hline 2908.7 & 2.3604 & 2360.40 & & \\
\hline 2961.7 & 2.3914 & 2391.40 & & \\
\hline 3000.8 & 2.4074 & 2407.40 & & \\
\hline 3032.8 & 2.4254 & 2425.40 & & \\
\hline 3038.8 & 2.4288 & 2428.75 & & \\
\hline
\end{tabular}

\begin{tabular}{|c|c|c|c|c|}
\hline \multicolumn{5}{|c|}{ Okoki-1 Time Depth Results } \\
\hline $\begin{array}{l}\text { True Vertical } \\
\text { Depth Sub-Sea } \\
\text { (m) }\end{array}$ & TWT (sec) & TWT (msec) & $\begin{array}{l}\text { Petroleum } \\
\text { Report } \\
\text { Number }\end{array}$ & Reference \\
\hline 0.0 & 0.0000 & 0.0 & \multirow{37}{*}{ PR1495 } & \multirow{37}{*}{$\begin{array}{l}\text { TCPL Resources Ltd, 1989. Well Completion } \\
\text { Report Okoki-1 PPL38438. Ministry of } \\
\text { Economic Development New Zealand } \\
\text { Unpublished Petroleum Report } 1495 .\end{array}$} \\
\hline 168.6 & 0.1820 & 182.0 & & \\
\hline 468.6 & 0.4138 & 413.8 & & \\
\hline 553.6 & 0.4898 & 489.8 & & \\
\hline 658.6 & 0.5760 & 576.0 & & \\
\hline 728.6 & 0.6292 & 629.2 & & \\
\hline 843.6 & 0.7130 & 713.0 & & \\
\hline 943.6 & 0.7852 & 785.2 & & \\
\hline 1068.6 & 0.8734 & 873.4 & & \\
\hline 1188.6 & 0.9502 & 950.2 & & \\
\hline 1333.6 & 1.0394 & 1039.4 & & \\
\hline 1468.6 & 1.1186 & 1118.6 & & \\
\hline 1568.6 & 1.1778 & 1177.8 & & \\
\hline 1703.6 & 1.2510 & 1251.0 & & \\
\hline 1830.6 & 1.3214 & 1321.4 & & \\
\hline 1918.6 & 1.3678 & 1367.8 & & \\
\hline 2032.6 & 1.4228 & 1422.8 & & \\
\hline 2218.6 & 1.5190 & 1519.0 & & \\
\hline 2298.6 & 1.5594 & 1559.4 & & \\
\hline 2558.6 & 1.6914 & 1691.4 & & \\
\hline 2758.6 & 1.7840 & 1784.0 & & \\
\hline 2948.6 & 1.8752 & 1875.2 & & \\
\hline 3068.6 & 1.9280 & 1928.0 & & \\
\hline 3158.6 & 1.9686 & 1968.6 & & \\
\hline 3248.6 & 2.0096 & 2009.6 & & \\
\hline 3338.6 & 2.0516 & 2051.6 & & \\
\hline 3428.6 & 2.0916 & 2091.6 & & \\
\hline 3518.6 & 2.1330 & 2133.0 & & \\
\hline 3608.6 & 2.1780 & 2178.0 & & \\
\hline 3698.7 & 2.2242 & 2224.2 & & \\
\hline 3788.5 & 2.2664 & 2266.4 & & \\
\hline 3818.6 & 2.2826 & 2282.6 & & \\
\hline 3908.7 & 2.3206 & 2320.6 & & \\
\hline 3998.5 & 2.3520 & 2352.0 & & \\
\hline 4088.5 & 2.3904 & 2390.4 & & \\
\hline 4178.6 & 2.4288 & 2428.8 & & \\
\hline 4228.6 & 2.4574 & 2457.4 & & \\
\hline
\end{tabular}


Taimana-1 Time-Depth Results

\begin{tabular}{|c|c|c|c|c|}
\hline \multicolumn{5}{|c|}{ Taimana-1 Time-Depth Results } \\
\hline $\begin{array}{c}\text { True Vertical } \\
\text { Depth Sub-Sea } \\
\text { (m) }\end{array}$ & TWT (sec) & TWT (msec) & $\begin{array}{l}\text { Petroleum } \\
\text { Report } \\
\text { Number }\end{array}$ & Reference \\
\hline 0.0 & 0 & 0.0 & \multirow{16}{*}{ PR1026 } & \multirow{16}{*}{$\begin{array}{l}\text { Diamond Shamrock Exploration Oil Co (NZ), } \\
\text { 1984. Final Well Report Taimana-1 PPL } 38109 . \\
\text { Ministry of Economic Development New Zealand } \\
\text { Unpublished Petroleum Report } 1026 .\end{array}$} \\
\hline 134.0 & 0.1780 & 178.0 & & \\
\hline 433.0 & 0.5080 & 508.0 & & \\
\hline 1064.0 & 1.1180 & 1118.0 & & \\
\hline 1464.0 & 1.4440 & 1444.0 & & \\
\hline 1974.0 & 1.7940 & 1794.0 & & \\
\hline 2469.0 & 2.0980 & 2098.0 & & \\
\hline 2901.0 & 2.3320 & 2332.0 & & \\
\hline 3167.0 & 2.4720 & 2472.0 & & \\
\hline 3194.0 & 2.4860 & 2486.0 & & \\
\hline 3224.0 & 2.5020 & 2502.0 & & \\
\hline 3363.0 & 2.5920 & 2592.0 & & \\
\hline 3574.0 & 2.7300 & 2730.0 & & \\
\hline 3714.0 & 2.8240 & 2824.0 & & \\
\hline 3996.0 & 2.9940 & 2994.0 & & \\
\hline 4172.0 & 3.0960 & 3096.0 & & \\
\hline
\end{tabular}

\begin{tabular}{|c|c|c|c|c|}
\hline \multicolumn{5}{|c|}{ Witiora-1 Time-Depth Results } \\
\hline $\begin{array}{l}\text { True Vertical } \\
\text { Depth Sub- } \\
\text { Sea }(\mathrm{m})\end{array}$ & TWT (sec) & TWT (msec) & $\begin{array}{l}\text { Petroleum } \\
\text { Report } \\
\text { Number }\end{array}$ & Reference \\
\hline 0.0 & 0.0000 & 0.0 & \multirow{8}{*}{ PR1037 } & \multirow{8}{*}{$\begin{array}{c}\text { New Zealand Oil \& Gas Ltd, 1984. Witiora-1 } \\
\text { completion report, PPL 38113. Offshore } \\
\text { Taranaki. Ministry of Economic Development } \\
\text { New Zealand Unpublished Petroleum Report } \\
1037 .\end{array}$} \\
\hline 491.5 & 0.5772 & 577.2 & & \\
\hline 974.0 & 1.0496 & 1049.6 & & \\
\hline 3384.0 & 2.5934 & 2593.4 & & \\
\hline 3749.0 & 2.8150 & 2815.0 & & \\
\hline 3889.0 & 2.8764 & 2876.4 & & \\
\hline 4174.0 & 3.0144 & 3014.4 & & \\
\hline 4202.0 & 3.0234 & 3023.4 & & \\
\hline
\end{tabular}




\section{D.5 Key Well Deviation Curve Results}

\begin{tabular}{|c|c|c|c|c|c|c|c|}
\hline \multicolumn{8}{|c|}{ Arawa-1 Well Deviation Results } \\
\hline $\begin{array}{l}\text { Measured } \\
\text { Depth }(m)\end{array}$ & $\begin{array}{c}\text { True } \\
\text { Vertical } \\
\text { Depth }(m)\end{array}$ & $\begin{array}{c}\text { Inclination } \\
\text { (deg) }\end{array}$ & $\begin{array}{c}\text { Azimuth } \\
\text { (deg) }\end{array}$ & $\begin{array}{l}\text { Difference } \\
\left(- \text { WIE }^{+}\right)(\mathrm{m})\end{array}$ & $\begin{array}{l}\text { Difference } \\
(-\mathrm{S} / \mathrm{N}+)(\mathrm{m})\end{array}$ & \begin{tabular}{|c|} 
Petroleum \\
Report \\
Number
\end{tabular} & Reference \\
\hline 0.00 & 0.00 & 0.00 & 0.0 & 0.00 & 0.00 & \multirow{34}{*}{ PR1824 } & \multirow{34}{*}{$\begin{array}{l}\text { ARCO Petroleum NZ Inc } \\
\text { (1992). Arawa-1 Final } \\
\text { well report PPL38436. } \\
\text { Unpublished Petroleum } \\
\text { Report 1824, New } \\
\text { Zealand Petroleum \& } \\
\text { Minerals, Wellington. }\end{array}$} \\
\hline 689.47 & 689.46 & 0.50 & 240.5 & -2.62 & -1.48 & & \\
\hline 718.19 & 718.18 & 0.50 & 240.5 & .2 .24 & -1.60 & & \\
\hline 746.35 & 746.34 & 0.00 & 0.0 & -2.94 & -1.67 & & \\
\hline 774.88 & 774.87 & 0.25 & 130.5 & .2 .90 & -1.71 & & \\
\hline 803.22 & 803.21 & 0.50 & 205.5 & -2.90 & -1.86 & & \\
\hline 831.80 & 831.79 & 0.25 & 295.5 & -3.01 & -1.94 & & \\
\hline 859.43 & 859.42 & 0.00 & 0.0 & -3.07 & -1.92 & & \\
\hline 888.57 & 888.56 & 0.50 & 160.5 & .3 .02 & -2.04 & & \\
\hline 917.14 & 917.13 & 0.25 & 190.5 & -2.99 & -2.22 & & \\
\hline 945.24 & 945.23 & 0.25 & 220.5 & -3.04 & -2.32 & & \\
\hline 972.75 & 972.74 & 0.50 & 140.5 & -3.01 & -2.46 & & \\
\hline 1000.73 & 1000.72 & 0.50 & 170.5 & -2.91 & -2.68 & & \\
\hline 1028.61 & 1028.60 & 0.25 & 215.5 & -2.93 & -2.85 & & \\
\hline 1057.33 & 1057.32 & 0.25 & 340.5 & -2.98 & -2.84 & & \\
\hline 1085.43 & 1085.41 & 0.50 & 130.5 & -2.91 & -2.86 & & \\
\hline 1114.93 & 1114.91 & 0.50 & 145.5 & -2.74 & -3.05 & & \\
\hline 1142.99 & 1142.97 & 0.00 & 0.0 & -2.67 & -3.15 & & \\
\hline 1171.67 & 1171.65 & 0.25 & 130.5 & -2.62 & -3.19 & & \\
\hline 1200.63 & 1200.61 & 0.25 & 125.5 & -2.52 & -3.27 & & \\
\hline 1229.41 & 1229.39 & 0.50 & 190.5 & -2.49 & -3.43 & & \\
\hline 1258.60 & 1258.58 & 0.50 & 180.5 & .252 & -3.68 & & \\
\hline 1287.54 & 1287.52 & 0.50 & 35.5 & -2.45 & -3.70 & & \\
\hline 1316.02 & 1316.00 & 0.25 & 35.5 & 2.34 & -3.55 & & \\
\hline 1324.87 & 1324.85 & 0.25 & 135.5 & -2.31 & -3.55 & & \\
\hline 1373.45 & 1373.43 & 0.25 & 240.5 & -2.33 & -3.68 & & \\
\hline 1401.10 & 1401.08 & 0.00 & 0.0 & -2.38 & -3.71 & & \\
\hline 1429.83 & 1429.81 & 0.25 & 65.5 & .2 .33 & -3.68 & & \\
\hline 1458.33 & 1458.31 & 0.50 & 65.5 & -2.16 & -3.60 & & \\
\hline 1467.80 & 1467.78 & 0.25 & 115.5 & -2.10 & -3.60 & & \\
\hline 1477.27 & 1477.25 & 0.25 & 75.5 & -2.06 & -3.60 & & \\
\hline 1491.80 & 1491.78 & 0.25 & 170.5 & -2.03 & -3.62 & & \\
\hline 3055.00 & 3054.97 & & & & & & \\
\hline 3056.84 & 3056.81 & & & & & & \\
\hline
\end{tabular}




\begin{tabular}{|c|c|c|c|c|c|c|c|}
\hline \multicolumn{8}{|c|}{ Okoki-1 Well Deviation Results } \\
\hline $\begin{array}{l}\text { Measured } \\
\text { Depth }(\mathrm{m})\end{array}$ & $\begin{array}{c}\text { Azimuth } \\
\text { (deg) }\end{array}$ & \begin{tabular}{|c|} 
True \\
Vertical \\
Depth $(\mathrm{m})$ \\
\end{tabular} & $\begin{array}{c}\text { Inclination } \\
\text { (deg) }\end{array}$ & $\begin{array}{l}\text { Difference } \\
\left(-W^{\prime} E+\right)(m)\end{array}$ & $\begin{array}{l}\text { Difference } \\
(-\mathrm{S} / \mathrm{N}+)(\mathrm{m})\end{array}$ & \begin{tabular}{|c|} 
Petroleum \\
Report \\
Number \\
\end{tabular} & Reference \\
\hline 0.0 & 0.00 & \begin{tabular}{l|l}
0 \\
\end{tabular} & 0 & 0.00 & 0.00 & \multirow{53}{*}{ PR1824 } & \multirow{53}{*}{$\begin{array}{l}\text { TCPL Resources Ltd } \\
\text { (1989). Well Completion } \\
\text { Report Okoki-1 } \\
\text { PPL38438. Unpublished } \\
\text { Petroleum Report 1495, } \\
\text { New Zealand Petroleum } \\
\text { \& Minerals, Wellington. }\end{array}$} \\
\hline 121.0 & 121.00 & \multirow{52}{*}{ Not col } & & 0.06 & 0.00 & & \\
\hline 149.0 & 149.00 & & & 0.24 & 0.00 & & \\
\hline 178.0 & 178.00 & & & 0.49 & 0.00 & & \\
\hline 277.0 & 276.39 & & & 1.35 & 0.00 & & \\
\hline 372.0 & 371.79 & & & 2.18 & 0.00 & & \\
\hline 476.0 & 475.48 & & & 3.32 & 0.00 & & \\
\hline 570.0 & 569.98 & & & 4.35 & 0.00 & & \\
\hline 594.0 & 593.98 & & & 4.56 & 0.01 & & \\
\hline 622.0 & 621.98 & & & 4.68 & 0.02 & & \\
\hline 651.0 & 650.98 & & & 4.73 & 0.06 & & \\
\hline 679.0 & 678.98 & & & 4.75 & 0.24 & & \\
\hline 707.0 & 706.98 & & & 4.69 & 0.48 & & \\
\hline 736.0 & 735.98 & & & 4.64 & 0.73 & & \\
\hline 764.0 & 763.97 & & & 4.59 & 0.90 & & \\
\hline 792.0 & 791.97 & & & 4.63 & 0.95 & & \\
\hline 821.0 & 820.97 & & & 4.69 & 0.97 & & \\
\hline 848.0 & 847.97 & & & 4.78 & 1.04 & & \\
\hline 877.0 & 876.97 & & & 4.87 & 0.96 & & \\
\hline 905.0 & 904.97 & & & 4.95 & 0.86 & & \\
\hline 933.0 & 932.97 & & & 5.12 & 0.93 & & \\
\hline 962.0 & 961.97 & & & 5.37 & 0.89 & & \\
\hline 991.0 & 990.97 & & & 5.49 & 0.74 & & \\
\hline 1019.0 & 1018.97 & & & 5.54 & 71.00 & & \\
\hline 1047.0 & 1046.97 & & & 5.60 & 74.00 & & \\
\hline 1076.0 & 1075.97 & & & 5.63 & 0.86 & & \\
\hline 1104.0 & 1103.97 & & & 5.67 & 0.91 & & \\
\hline 1133.0 & 1132.97 & & sllected. & 5.73 & 0.92 & & \\
\hline 1161.0 & 1160.97 & & & 5.82 & 0.99 & & \\
\hline 1190.0 & 1189.97 & & & 5.97 & 1.08 & & \\
\hline 1219.0 & 1218.97 & & & 6.14 & 1.15 & & \\
\hline 1247.0 & 1246.97 & & & 6.26 & 1.11 & & \\
\hline 1276.0 & 1275.97 & & & 6.21 & 0.99 & & \\
\hline 1304.0 & 1303.97 & & & 6.20 & 0.87 & & \\
\hline 1333.0 & 1332.97 & & & 6.26 & 0.86 & & \\
\hline 1361.0 & 1360.97 & & & 6.33 & 0.76 & & \\
\hline 1389.0 & 1388.97 & & & 6.27 & 0.46 & & \\
\hline 1417.0 & 1416.97 & & & 6.26 & 0.21 & & \\
\hline 1446.0 & 1445.97 & & & 6.18 & 0.12 & & \\
\hline 1474.0 & 1473.96 & & & 6.14 & 0.00 & & \\
\hline 1502.0 & 1501.96 & & & 6.22 & -0.09 & & \\
\hline 1530.0 & 1529.96 & & & 6.15 & -0.18 & & \\
\hline 1559.0 & 1558.96 & & & 5.98 & -0.09 & & \\
\hline 1588.0 & 1587.96 & & & 5.70 & 0.07 & & \\
\hline 1616.0 & 1615.96 & & & 5.52 & 0.31 & & \\
\hline 1645.0 & 1644.96 & & & 5.44 & 0.55 & & \\
\hline 1673.0 & 1672.96 & & & 5.36 & 0.85 & & \\
\hline 1702.0 & 1701.96 & & & 5.24 & 1.20 & & \\
\hline 1730.0 & 1729.95 & & & 5.08 & 1.47 & & \\
\hline 1758.0 & 1757.95 & & & 4.95 & 1.67 & & \\
\hline 1786.0 & 1785.95 & & & 4.81 & 1.87 & & \\
\hline 1796.0 & 1795.95 & & & 4.77 & 1.95 & & \\
\hline 4257.5 & 4257.45 & & & 4.77 & 1.95 & & \\
\hline
\end{tabular}


Taimana-1 Well Deviation Results (Assumed Vertical)

\begin{tabular}{|c|c|c|c|c|c|c|c|}
\hline $\begin{array}{l}\text { Measured } \\
\text { Depth }(m)\end{array}$ & $\begin{array}{c}\text { Azimuth } \\
\text { (deg) }\end{array}$ & \begin{tabular}{|c|} 
True \\
Vertical \\
Depth $(\mathrm{m})$
\end{tabular} & $\begin{array}{c}\text { Inclination } \\
\text { (deg) }\end{array}$ & $\begin{array}{l}\text { Difference } \\
(-W / E+)(m)\end{array}$ & $\begin{array}{l}\text { Difference } \\
(-\mathrm{S} / \mathrm{N}+)(\mathrm{m})\end{array}$ & \begin{tabular}{|c|} 
Petroleum \\
Report \\
Number
\end{tabular} & \\
\hline 0.0 & 0.0 & 0 & 0 & 0 & 0 & \multirow{2}{*}{ PR1824 } & \multirow{2}{*}{ 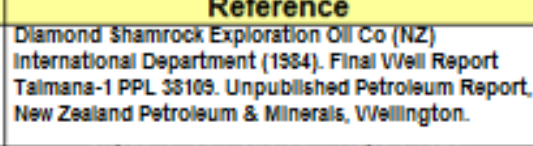 } \\
\hline 4195.0 & 4195.0 & 0 & 0 & 0 & 0 & & \\
\hline
\end{tabular}

\begin{tabular}{|c|c|c|c|c|c|c|c|}
\hline \multicolumn{8}{|c|}{ Witiora-1 Well Deviation Results (Assumed Vertical) } \\
\hline $\begin{array}{l}\text { Measured } \\
\text { Depth }(m)\end{array}$ & $\begin{array}{c}\text { Azimuth } \\
\text { (deg) }\end{array}$ & \begin{tabular}{|c|} 
True \\
Vertical \\
Depth $(\mathrm{m})$
\end{tabular} & $\begin{array}{c}\text { Inclination } \\
\text { (deg) }\end{array}$ & $\begin{array}{l}\text { Difference } \\
(-W / E+)(m)\end{array}$ & $\begin{array}{l}\text { Difference } \\
(-\mathrm{S} / \mathrm{N}+)(\mathrm{m})\end{array}$ & $\begin{array}{l}\text { Petroleum } \\
\text { Report } \\
\text { Number }\end{array}$ & Reference \\
\hline 0.0 & 0.0 & 0 & 0 & 0 & 0 & \multirow{2}{*}{ PR1037 } & \multirow{2}{*}{$\begin{array}{l}\text { New Zealand Oil \& Gas Ltd (1984). Witiora-1 well } \\
\text { completion report, PPL } 38113 \text {. Offshore } \\
\text { Taranaki. Unpublished Petroleum Report, New } \\
\text { Zealand Petroleum \& Minerals, Wellington }\end{array}$} \\
\hline 4229.0 & 4229.0 & 0 & 0 & 0 & 0 & & \\
\hline
\end{tabular}

